Lais Helena Teixeira

Geração e análise da imunogenicidade de proteínas recombinantes baseadas nas diferentes formas do antígeno circumsporozoíta de Plasmodium vivax visando o desenvolvimento de uma vacina universal contra malária

Tese apresentada ao Programa de Pós-Graduação em Imunologia do Instituto de Ciências Biomédicas da Universidade de São Paulo, para obtenção do Título de Doutor em Ciências. 
Lais Helena Teixeira

\section{Geração e análise da imunogenicidade de proteínas recombinantes baseadas nas diferentes formas do antígeno circumsporozoíta de Plasmodium vivax visando o desenvolvimento de uma vacina universal contra malária}

Tese apresentada ao Programa de Pós-Graduação em Imunologia do Instituto de Ciências Biomédicas da Universidade de São Paulo, para obtenção do Título de Doutor em Ciências.

Área de concentração: Imunologia

Orientador: Prof. Dr. Mauricio Martins Rodrigues

Versão Corrigida. Versão original eletrônica encontra-se disponível tanto na biblioteca do ICB quanto na biblioteca digital de teses e dissertações da USP (BDTD).

São Paulo

2014 


\section{DADOS DE CATALOGAÇÃO NA PUBLICAÇÃO (CIP)}

Serviço de Biblioteca e Informação Biomédica do

Instituto de Ciências Biomédicas da Universidade de São Paulo

(c) reprodução total

Teixeira, Lais Helena.

Geração e análise da imunogenicidade de proteínas recombinantes baseadas nas diferentes formas do antígeno circumsporozoíta de Plasmodium vivax visando o desenvolvimento de uma vacina universal contra malária / Lais Helena Teixeira. -- São Paulo, 2014.

Orientador: Prof. Dr. Mauricio Martins Rodrigues.

Tese (Doutorado) - Universidade de São Paulo. Instituto de Ciências Biomédicas. Departamento de Imunologia. Área de concentração: Imunologia. Linha de pesquisa: Estudo da resposta imune induzida por vacina contra o Plasmodium vivax.

Versão do título para o inglês: Generation and analysis of the immunogenicity of recombinant proteins based on differebt forms of the circumsporozoite antigen of Plasmodium vivax for the development of a universal vaccine against malaria.

1. Plasmodium vivax 2. Vacina 3. Proteína recombinante 4. Adenovírus recombinante 5. Adjuvante I. Rodrigues, Prof. Dr. Mauricio Martins II. Universidade de São Paulo. Instituto de Ciências Biomédicas. Programa de Pós-Graduação em Imunologia III. Título. 
Candidato(a):

Título da Tese:

Orientador(a):

\section{Lais Helena Teixeira.}

Geração e análise da imunogenicidade de proteínas recombinantes baseadas nas diferentes formas do antígeno circumsporozoíta de Plasmodium vivax visando o desenvolvimento de uma vacina universal contra malária.

Prof. Dr. Mauricio Martins Rodrigues.

A Comissão Julgadora dos trabalhos de Defesa da Tese de Doutorado, em sessão pública realizada a

( ) Aprovado(a)
I. I. considerou

\section{( ) Reprovado(a)}

\begin{tabular}{|c|c|}
\hline Examinador(a): & $\begin{array}{l}\text { Assinatura: } \\
\text { Nome: ......... } \\
\text { Instituição: . }\end{array}$ \\
\hline Examinador(a): & $\begin{array}{l}\text { Assinatura: } \\
\text { Nome: ......... } \\
\text { Instituição: . }\end{array}$ \\
\hline Examinador(a): & $\begin{array}{l}\text { Assinatura: } \\
\text { Nome: ........ } \\
\text { Instituição: . }\end{array}$ \\
\hline Examinador(a): & $\begin{array}{l}\text { Assinatura: } \\
\text { Nome: ......... } \\
\text { Instituição: . }\end{array}$ \\
\hline Presidente: & $\begin{array}{l}\text { Assinatura: } \\
\text { Nome: ......... } \\
\text { Instituição: . }\end{array}$ \\
\hline
\end{tabular}




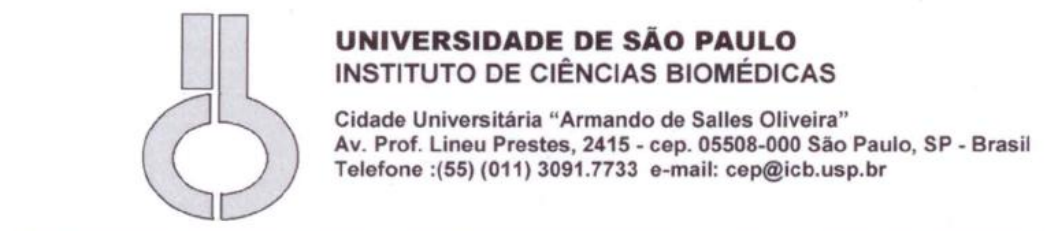

Of.CEUA.051.12

WTL/mcgn

São Paulo, 13 de junho de 2012.

REF.: Protocolo $n^{\circ} 55.08$.

"Resposta imune a antígenos de protozoários patogênicos com ênfase no desenvolvimento de vacinas recombinantes".

Prezado Professor,

Informo que a sua licença para uso de animais em experimentação, constante no protocolo em epígrafe, fol prorrogada até 22.06.2014.

Reitero que havendo alteração de metodologia e inserção de novos alunos ao projeto de pesquisa vinculado à referida licença a CEUA/ICB deverá ser informada.

Cordialmente,

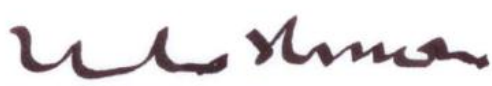

Prof. Dr. WOTHAN TAVARES DE LIMA

Coordenador - CEUA-ICB/ /USP

IImo.Sr.

Prof. Dr. MAURICIO MARTINS RODRIGUES

Departamento de Imunologia

Instituto de Ciências Biomédicas - USP 


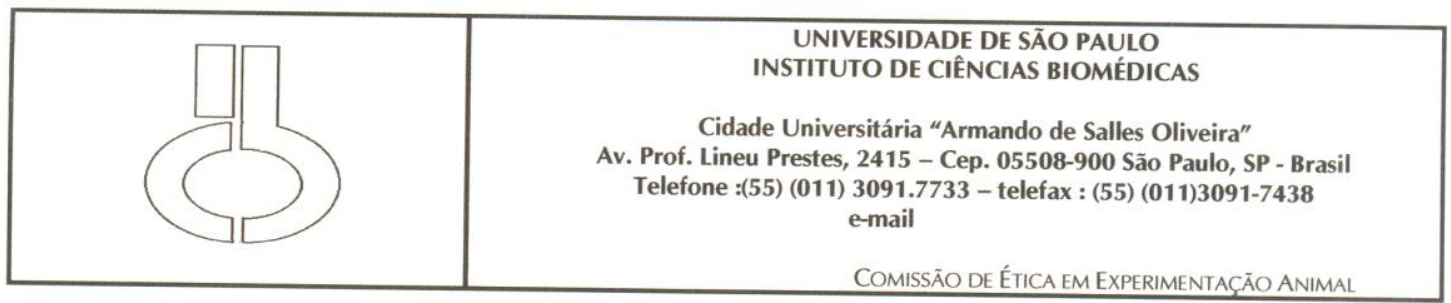

Decl. CEEA.66.09

\section{E C L A R A Ç Ã O}

Em adendo ao Certificado 55/08/CEEA datado de 25/11/08, por solicitação do Prof. Dr. Mauricio Martins Rodrigues, responsável pela linha de Pesquisa, autorizo a inclusão da aluna Laís Helena Teixeira ao projeto de pesquisa "Resposta imune a antígenos de protozoários patogênicos com ênfase no desenvolvimento de vacinas recombinantes", uma vez que se trata de utilização da mesma espécie animal e de métodos experimentais similares ao referido certificado.

São Paulo, 06 de outubro de 2009.

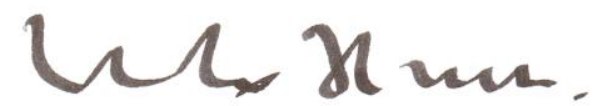

Prof. Dr. WOTHAN TAVARES DE LIMA

Coordenador -CEEA- ICB/USP 
Á minha mãe, Wanda, por ser o meu espelho, minha ídola, por toda força e incentivo, e por despertar em mim o gosto de ensinar. Ao meu pai, Antonio Carlos, por todo apoio, incentivo, pensamentos positivos, e por despertar em mim o gosto pela biologia. Ao meu marido, cúmplice e companheiro de todas as horas, Daniel, por toda força, por todo apoio, por toda compreensão e por toda paciência. Ás minhas irmãs, Carol e Amanda, por toda força e apoio doados para mim. Á minha querida avó, Cida, por toda preocupação, e por todas as noites que ficou esperando por um simples sorriso meu antes de dormir. Saudades de você! 


\section{AGRADECIMENTOS}

Quero agradecer ao Deus que acredito guiar todos os momentos da minha vida, guiar as minhas escolhas, minhas atitudes. Agradeço por toda a força e fé que despertou em mim durante estes anos de doutoramento, e por me fazer acreditar que com muito esforço, dedicação e perseverança, tudo é possível.

Agradeço a minha mãe, Wanda, e ao meu pai, Antonio Carlos, por me ensinarem valores que realmente são importantes e determinantes na vida das pessoas, como: "O respeito ao próximo". Quando respeitamos a opinião alheia, as diferenças de cada ser humano, e seus limites, estamos também nos respeitando. Obrigada por cada pensamento positivo, pelos "colos, ombros e ouvidos emprestados", por toda cumplicidade, pela confiança, incentivo e por todo amor e carinho que vocês têm por mim. Agradeço por ser quem sou, por quem me tornei, e por inspirarem como eu serei futuramente com meus filhos.

Agradeço o companheirismo, a cumplicidade, a força, todo o apoio, toda paciência e compreensão do meu marido, Daniel. Você também é parte fundamental do meu crescimento pessoal e profissional. Sem o seu apoio esta jornada seria um pouco mais difícil. Obrigada por estar sempre do meu lado!

Agradeço as minhas irmãs Carol e Amanda, por todo incentivo, por entenderem e apoiarem este momento importantíssimo para minha carreira profissional.

Enfim, agradeço a todos da minha família, por respeitarem este momento da minha vida, e por compreenderem todas as recusas de atenção, de passeios e de distração. Desculpem a minha ausência!

Não posso deixar de agradecer às pessoas que também considero parte da família: Minhas amigas! Principalmente àquelas que escolheram uma profissão completamente diferente da minha, e compreenderam a minha escolha. Obrigada por toda amizade, carinho e apoio!

Agradeço o carinho de todas as pessoas que fizeram parte direta ou indiretamente da minha vida durante este processo de doutoramento.

Agradeço toda a cumplicidade, a solidariedade, a amizade, o apoio e o incentivo de amigas especiais que ganhei ao longo destes últimos anos, e que no momento estão longe fisicamente, mas sempre estão comigo em pensamento e no coração: Ariane, Mônica, Thatiana, Adriana, Letícia, Cibele e Paula. 
Agradeço a companhia, a força, o incentivo e todos os momentos que compartilhei com outras queridas amigas que conheci no CTCMol: Marina, Camila, Keyna, Mariana, Tainah, Thaís, Carla, Virgínia, Laura, Carina, Silvia, Kely e Bianca.

Quero fazer um agradecimento especial para minha amiga Ivanete, pois sem ela nosso trabalho simplesmente não acontece. Obrigada por tudo!

Agradeço ao meu orientador, Dr. Mauricio M. Rodrigues, por todas as oportunidades concedidas e financiadas, proporcionando assim o meu crescimento profissional e pessoal.

Agradeço o auxílio e a companhia dos demais colegas e colaboradores do laboratório: Adriano, Bruna, Daniel, Fernando, Jonatan, Ronnie e Vander.

Agradeço a colaboração da profa Dra. Irene e de todas as suas alunas, em especial Luciana, Katia e Elaine.

Agradeço o auxilio e colaboração dos professores do CTCMol, Dr. Hugo, Dra. Karina, Dra. Mônica, Dr. Sang, Dr. Silvio e Dr. Wagner. E dos funcionários, Magali, Sandra, Márcia, Paulo, Oswaldo, Danilo, João, Jerônimo, Sergio, e de todos os outros que trabalham ou trabalharam conosco e que são fundamentais para o bom funcionamento do centro.

Agradeço ao Departamento de Imunologia do ICB IV da USP, principalmente ao prof. Dr. Gustavo, aos secretários Maria Eni e João; agradeço ao Departamento de Microbiologia, Imunologia e Parasitologia da Unifesp, e a todos os demais professores e funcionários que colaboraram para a realização deste projeto.

E por fim, agradeço as instituições de amparo à pesquisa que financiaram o presente trabalho: INCTV, CAPES, CNPq e FAPESP. 
"Mantenha seus pensamentos positivos, porque seus pensamentos tornam-se suas palavras. Mantenha suas palavras positivas, porque suas palavras tornam-se suas atitudes. Mantenha suas atitudes positivas, porque suas atitudes tornam-se seus hábitos. Mantenha seus hábitos positivos, porque seus hábitos tornam-se seus valores. Mantenha seus valores positivos, porque seus valores tornam-se seu destino" (Mahatma Gandhi). 


\section{RESUMO}

Teixeira LH. Geração e análise da imunogenicidade de proteínas recombinantes baseadas nas diferentes formas do antígeno circumsporozoíta de Plasmodium vivax visando o desenvolvimento de uma vacina universal contra malária. [tese (Doutorado em Imunologia)]. São Paulo: Instituto de Ciências Biomédicas, Universidade de São Paulo; 2014.

O Plasmodium vivax é a segunda espécie mais prevalente causadora de malária no mundo. Medidas de controle ineficientes empregadas atualmente exigem o desenvolvimento de novas estratégias de prevenção, como vacinas, novas drogas e novos inseticidas. O objetivo geral do desta tese foi gerar uma formulação vacinal universal com proteínas e vetores adenovirais recombinantes representando as diferentes formas alélicas da proteína circumsporozoíta (CSP) do $P$. vivax. Inicialmente, genes codificando para cada uma das três formas alélicas da proteína CSP foram construídos. Um quarto gene foi construído contendo sequências de nucleotídeos que codificam as três regiões alélicas distintas em fusão. Estes genes foram inseridos no vetor de expressão bacteriano pET28a contendo uma sequência que codifica para a cauda de hexahistidina. As proteínas recombinantes foram expressas em E. coli e purificadas. A obtenção destas proteínas nos permitiu testar qual seria a melhor formulação vacinal para a indução de anticorpos contra as três formas alélicas da CSP. Camundongos C57BL/6 foram imunizados com as proteínas recombinantes em diferentes formulações vacinais, emulsificadas nos adjuvantes Completo e Incompleto de Freund ou misturadas com o agonista de TLR-3 Poly(I:C). A magnitude e longevidade da resposta imune foram determinadas por ELISA onde verificamos altos títulos duradouros de anticorpos contra as proteínas recombinantes representando as três formas alélicas da CSP nos animais imunizados com diferentes formulações vacinais. Os anticorpos específicos também reconheceram esporozoítas do $P$. vivax expressando a CSP das duas formas alélicas predominantes do parasita por imunofluorescência. A análise da especificidade destes anticorpos demonstrou que há o reconhecimento das regiões repetidas e não-repetidas das diferentes formas alélica da CSP. Por fim, testamos o uso de dois vetores adenovirais recombinantes, um símio e um humano, deficientes em replicação, expressando uma proteína contendo as regiões repetidas representando as três formas alélicas da CSP em fusão. Estes vetores adenovirais foram capazes de induzir resposta imune específica contra a CSP. Estes vetores adenovirais foram usados com sucesso num esquema de imunização e reforço heterólogo onde na primeira dose os camundongos receberam o vetor adenoviral recombinante e nas doses subseqüentes, receberam uma mistura com as três proteínas recombinantes. Em suma, nesta tese descrevemos proteínas e vetores adenovirais recombinantes que podem ser úteis para o desenvolvimento de uma vacina universal contra a malária causada pelo $P$. vivax.

Palavras-chave: Plasmodium vivax. Vacina. Proteína recombinante. Adenovírus recombinante. Adjuvante. 


\begin{abstract}
Teixeira LH. Generation and analysis of the immunogenicity of recombinant proteins based on different forms of the circumsporozoite antigen of Plasmodium vivax for the development of a universal vaccine against malaria. [Ph. D thesis (Immunology)]. São Paulo: Instituto de Ciências Biomédicas, Universidade de São Paulo; 2014.

The Plasmodium vivax is the second most prevalent species of malaria in the world. Inefficient measures of control used today demand the development of new strategies for prevention, as vaccines, new drugs and new insecticides. The central objective of this thesis was to generate a universal vaccine formulation with proteins and recombinant adenoviral vectors representing the different allelic forms of the circumsporozoite protein (CSP) of the P. vivax. Initially, we engineered genes encoding each one of the three allelic forms of CSP. A fourth gene contained the nucleotide sequences encoding the three distinct allelic regions in fusion. These genes were inserted in the bacterial expression vector pET28a containing a sequence encoding the hexahistidina tag. The recombinant proteins were expressed in E. coli and purified. These proteins allowed us to test which would be the best vaccine formulation for the induction of antibodies against the three allelic forms of CSP. C57BL/6 mice were immunized with recombinant proteins in different vaccine formulations emulsified in Complete and the Incomplete Freund adjuvant or admixed with the TLR-3 agonist of Poly (I:C). The magnitude and longevity of the immune response were determined by ELISA where we verify high and long lasting antibody titers against the recombinant proteins representing the three allelic forms of CSP in the animals immunized with different vaccine formulations. The specific antibodies also recognized $P$. vivax sporozoites expressing CSP of the two predominant allelic forms of the protein by immunofluorescence. The analysis of the specificity of these antibodies demonstrated that they recognized of the repeats and non-repeated regions of the different allelic forms of CSP. Finally we test the use of two recombinant adenoviral vectors, a simian and a human, both replication deficient, expressing a protein containing the repeat regions representing the three allelic forms of the CSP in fusion. These adenoviral vectors induced specific immune response against CSP. These adenoviral vectors were successfully used in an immunization regimen of heterologous prime and boost where in the first dose the mice received recombinant adenoviral vector and in the subsequent doses, the mixture with three recombinant proteins. In summary, in this thesis we describe recombinant proteins and adenoviral vectors that can be useful for the development of a universal vaccine against the malaria caused by $P$. vivax.
\end{abstract}

Keywords: Plasmodium vivax. Vaccine. Recombinant protein. Recombinant adenovirus. Adjuvant. 


\section{LISTA DE FIGURAS}

Figura 01: Distribuição mundial do Plasmodium vivax.......................................................23

Figura 02: Número de casos de malária no Brasil, nos últimos 50 anos $(1960$ - 2010).............26

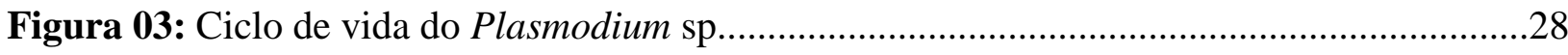

Figura 04: $\mathrm{O}$ esquema acima mostra os principais mecanismos que medeiam a imunidade contra

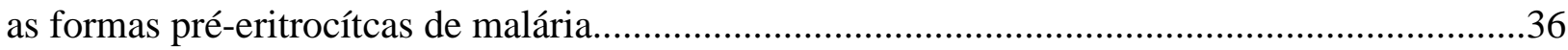

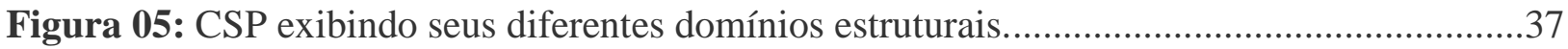

Figura 06: Diferentes regiões da África selecionadas para o teste clínico de fase III da RTS,S/AS01

Figura 07: Resultados preliminares da eficácia da vacinação com a formulação RTS,S/AS01.

Figura 08: Eficácia da vacinação com a formulação RTS,S/AS01 em ensaio clínico de fase III. 45

Figura 09: Concentração sérica de anticorpos específicos contra a região imunodominante da CSP de $P$. falciparum é importante para a eficácia da vacinação com a formulação RTS,S/AS01

Figura 10: Representação esquemática da CSP do $P$. vivax e as seqüências das regiões centrais com repetições de aa presentes em cada forma alélica (VK210, VK247 e Vivax-like)...............75

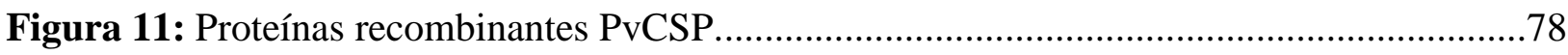

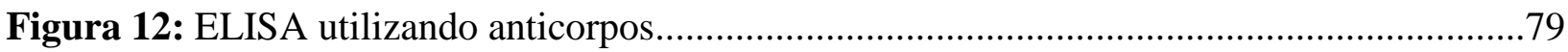

Figura 13: Títulos de anticorpos séricos ( $\operatorname{IgG}$ ) induzidos nos camundongos C57BL/6 imunizados com as diferentes formulações vacinais (indicadas na legenda) determinados por ELISA

Figura 14: Comparação entre os títulos de anticorpos séricos nos soros dos camundongos C57BL/6 imunizados com as três proteínas misturadas na presença dos adjuvantes Poly(I:C) ou CFA/IFA, e dos soros dos camundongos C57BL/6 imunizados com His ${ }_{6} \mathrm{PvCSP}-\mathrm{All}-\mathrm{CS}$-epitopes, na presença dos mesmos adjuvantes, após a terceira dose vacinal

Figura 15: Títulos de anticorpos séricos (IgG) induzidos nos camundongos C57BL/6 imunizados com as diferentes doses da formulação vacinal determinados por ELISA. . .85

Figura 16: Títulos de anticorpos séricos $(\mathrm{IgG})$ induzidos nos camundongos C57BL/6 $\mathrm{tlr} 4^{+/+}$ou tlr $4^{-/-}$imunizados com as proteínas recombinantes da PvCSP . .86

Figura 17: Comparação da resposta imune induzida na presença dos adjuvantes Poly-ICLC (Hiltonol) e Poly(I:C). 
Figura 18: Adenovírus recombinantes deficientes em replicação expressando a PvCSP. 90

Figura 19: Indução de respostas de anticorpos específicos em camundongos imunizados com adenovírus recombinantes expressando PvCSP como parte de um regime de vacinação do tipo prime-boost heterólogo.

Figura 20: Longevidade da resposta de anticorpos específicos em camundongos imunizados com adenovírus recombinantes expressando PvCSP como parte de um regime de vacinação do tipo prime-boost heterólogo.

Figura 21: Especificidade dos anticorpos gerados após vacinações experimentais homóloga (proteína-proteína) ou heteróloga (adenovírus-proteína)

Figura 22: Representação esquemática das proteínas de fusão contendo as seqüências das regiões centrais repetidas de aa presentes em cada forma alélica da PvCSP (VK 210, VK247 e Vivax-like) . .96

Figura 23: Resposta imune de anticorpos específicos contra as regiões repetidas da PvCSP em camundongos imunizados segundo os regimes de vacinação homólogo ou heterólogo. .98

Figura 24: Reconhecimento da PvCSP nativa por anticorpos de C57BL/6 imunizados com os regimes de prime-boost homólogo ou heterólogo. 100

Figura 25: Determinação das subclasses de $\operatorname{IgG}$ dos anticorpos específicos nos soros dos animais vacinados com os diferentes protocolos experimentais. 101

Figura 26: Resposta imune celular após a vacinação com a PvCSP recombinante 103

Figura 27: Resposta imune celular após a vacinação com a PvCSP recombinante 104 


\section{LISTA DE TABELAS}

Tabela 01: Áreas e populações que vivem sob-risco de contrair malária causada pelo $P$. vivax

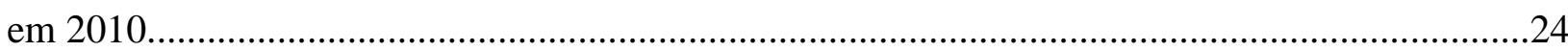

Tabela 02: Estudos desenvolvidos com candidatos antigênicos usados em formulações vacinais contra $P$. vivax...... 


\section{LISTA DE ABREVIATURAS E SIGLAS}

Ac

AdHu5

AdCH68

AMA

AS

BSA

CSP

CFA

DAP

DO

DP

ELISA

FPLC

g

GAS

GPI

GSK

$\mathrm{h}$

$\mathrm{H}_{2} \mathrm{O}_{2}$

$\mathrm{HCl}$

$\mathrm{H}_{2} \mathrm{SO}_{4}$

His

IFA
Anticorpo / Anticorpos

Adenovírus humano do tipo 5

Adenovírus símio do tipo 68

“Apical Membrane Antigen”

"Adjuvant systems"

"Bovine serum albumin"

"Circumporozoite surface protein"

"Complete Freund's adjuvant"

"Drug-arrested parasites"

Densidade Óptica

Desvio Padrão

"Enzyme-linked Immunosorbent Assay"

"Fast protein liquid chromatography"

Grama

"Genetically attenuated sporozoites"

Glicosilfosfatidilinositol

Glaxo Smith Kline

Hora

Peróxido de hidrogênio

Ácido clorídrico

Ácido sulfúrico

Histidina

"Incomplete Freund's adjuvant" 


\begin{tabular}{|c|c|}
\hline $\operatorname{Ig}$ & Imunoglobulina \\
\hline IFN- $\gamma$ & Interferon-gama \\
\hline IL & Interleucina \\
\hline i.m. & Intramuscular \\
\hline IPTG & Isopropil- $\beta$-d-tiogalactopiranosídio \\
\hline $\mathrm{KCl}$ & Cloreto de Potássio \\
\hline $\mathrm{kDa}$ & Quilo Dalton \\
\hline $\mathrm{KO}$ & "Knockout" \\
\hline $\mathrm{L}$ & Litro \\
\hline LB & Luria broth \\
\hline LSP & "Long Synthetic Peptides" \\
\hline LPS & Lipopolissacarídeo \\
\hline M & Molar \\
\hline $\mathrm{MAb}$ & "Monoclonal antibody" \\
\hline $\mathrm{mg}$ & Miligrama \\
\hline $\mathrm{MgCl}_{2}$ & Cloreto de Magnésio \\
\hline $\mathrm{MHC}$ & "Major histocompatibility complex" \\
\hline $\min$ & Minuto \\
\hline $\mathrm{mL}$ & Mililitro \\
\hline $\mathrm{mM}$ & Milimolar \\
\hline MPL A & "Monophosphoril lipid A" \\
\hline MSP & "Merozoite surface protein" \\
\hline $\mathrm{N}$ & Normal \\
\hline $\mathrm{Na}_{2} \mathrm{CO}_{3}$ & Carbonato de Sódio \\
\hline $\mathrm{NaCl}$ & Cloreto de Sódio \\
\hline $\mathrm{Na}_{2} \mathrm{HPO}_{4}$ & Fosfato de Sódio Bibásico \\
\hline $\mathrm{NaH}_{2} \mathrm{PO}_{4}$ & Fosfato de Sódio Monobásico \\
\hline
\end{tabular}




\begin{tabular}{|c|c|}
\hline $\mathrm{NaHCO}_{3}$ & Bicarbonato de Sódio \\
\hline ng & Nanograma \\
\hline $\mathrm{nm}$ & Nanômetro \\
\hline OPD & Ortofenilenodiamina \\
\hline PAMP & "Pathogen associated molecular pattern" \\
\hline PBS & "Phosphate-buffered saline" \\
\hline PMSF & Fluoreto de fenilmetil-sulfonila \\
\hline RAS & "Radiation-attenuated sporozoites" \\
\hline RPM & Rotação por minuto \\
\hline $\mathrm{s}$ & Segundo \\
\hline s.c. & Subcutânea \\
\hline SDS & "Sodium dodecyl sulfate" \\
\hline TEMED & $\mathrm{n}, \mathrm{n}, \mathrm{n}$, n' tetrametil etilenodiamida \\
\hline TLR & Receptor do tipo Toll \\
\hline TNF & "Tumor necrosis factor" \\
\hline VLP & "Virus-like particles" \\
\hline$\mu \mathrm{g}$ & Micrograma \\
\hline$\mu \mathrm{L}$ & Microlitro \\
\hline$\mu \mathrm{m}$ & Micrômetro \\
\hline $\mathrm{mM}$ & Micromolar \\
\hline$X$ & Vezes \\
\hline
\end{tabular}




\section{SUMÁRIO}

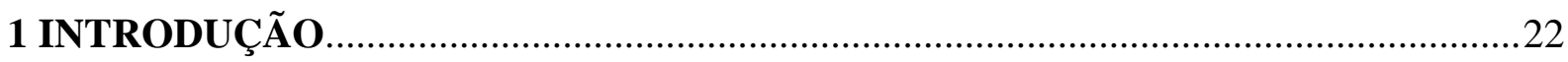

1.1 Epidemiologia da malária causada pelo Plasmodium vivax .................................... 23

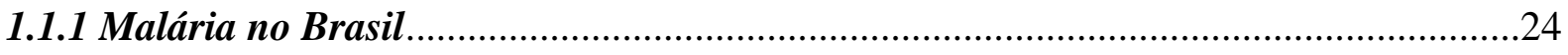

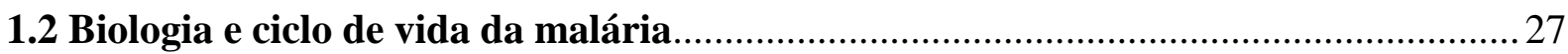

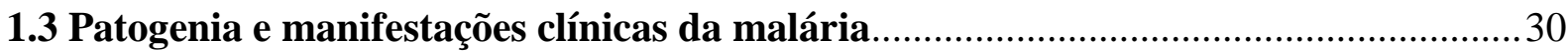

1.3.1 Resistência do P. vivax ao tratamento com Cloroquina ...............................................34

1.4 Mecanismos imunológicos contras as formas pré-eritrocíticas do Plasmodium sp e racional para o desenvolvimento de uma vacina contra malária baseado nestas.............35

1.5 Desenvolvimento de formulações vacinais contra os estágios pré-eritrocíticos da

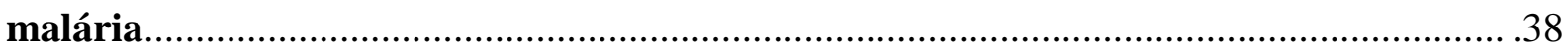

1.5.1 Formulações vacinais contendo parasitas vivos atenuados: RAS (esporozoítas atenuados por radiação), GAP (parasitas atenuados geneticamente) e DAP (parasitas imobilizados por droga).

1.6 Estratégias usando formulações vacinais recombinantes de subunidades contra malária.

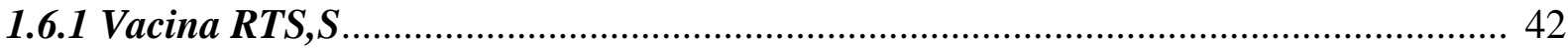

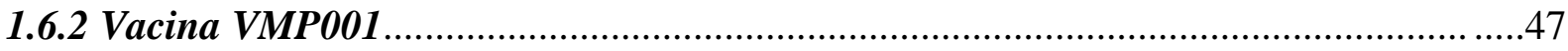

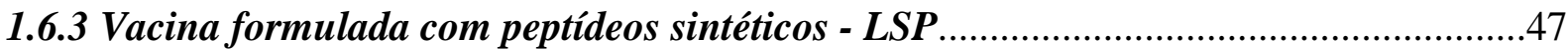

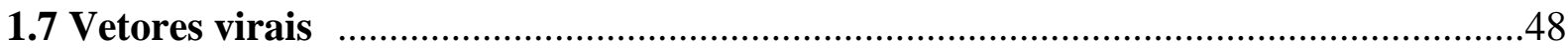

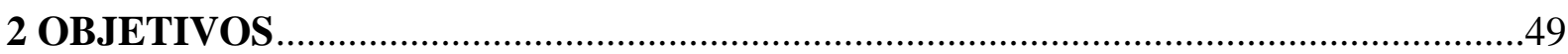

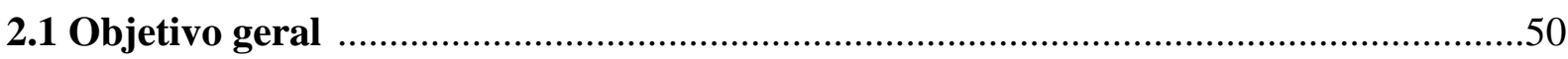

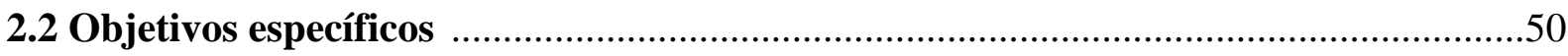

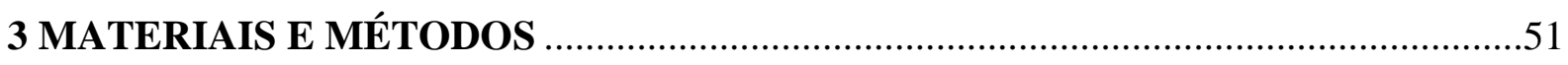

3.1 Composição das soluções e tampões utilizados.........................................................52

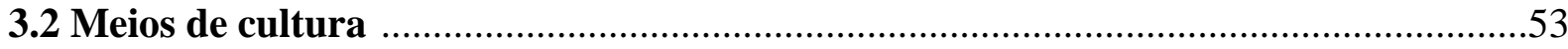

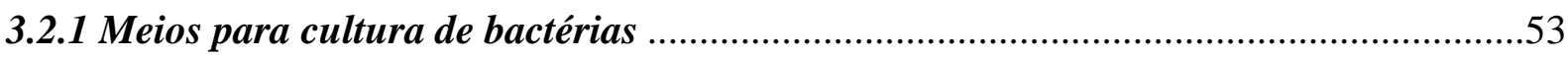

3.3 Geração dos genes sintéticos codificando cada uma das regiões variantes e, geração de um gene sintético codificando todas as três regiões variantes de aminoácidos,

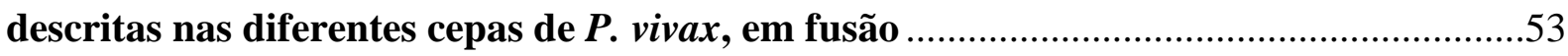

3.4 Geração dos genes sintéticos codificando cada uma das regiões variantes de

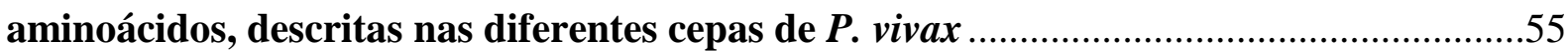


3.5 Geração de adenovírus recombinante humano Tipo 5 deficiente de replicação e adenovírus de chimpanzé Tipo 68 expressando a proteína CSP de $P$. vivax para sistema

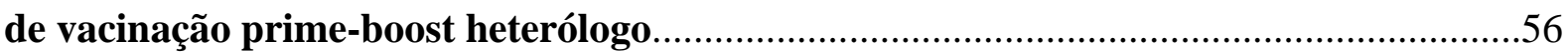

3.6 Transformação bacteriana utilizando vetor plasmidial.........................................57

3.7 Análise das colônias bacterianas por lise alcalina (Mini prep - in house) ...................57

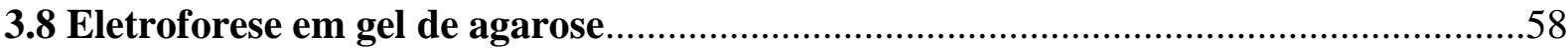

3.9 Análise em sistema de expressão bacteriano, utilizando cepa de $\boldsymbol{E}$ coli .....................58

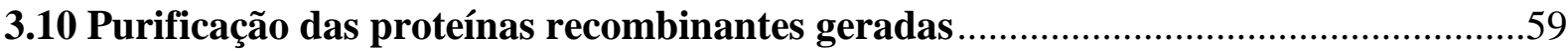

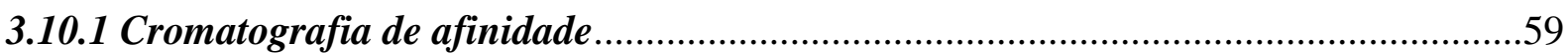

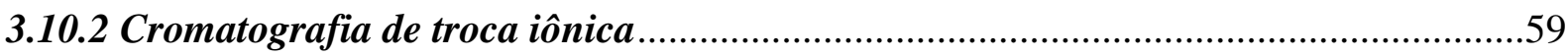

3.11 Produção de proteínas recombinantes expressas em fusão com a flagelina (FliC) de Salmonella enterica serovar Typhimurium.

3.12 Extração de LPS das proteínas recombinantes PvCSP utilizando agarose de polimixina B (Sigma)

3.13 Dosagem do LPS utilizando o Kit E-Toxate (Sigma)

3.14 Produção de proteínas recombinantes contendo sequência GST, em sistema bacteriano, utilizando cepa de $E$ coli

3.15 Purificação de proteínas recombinantes contendo sequência GST em agarose de Glutationa.

3.15.1 Cromatografia de afinidade

3.16 Transferência das proteínas para membranas de nitrocelulose e

"immunoblotting"

3.17 Animais

3.17.1 Imunização de camundongos com as proteínas recombinantes geradas na presença de diferentes formulações adjuvantes

3.18 Produção e purificação dos vetores adenovirais recombinantes 64

3.18.1 Produção de estoque viral 64

3.18.2 Purificação dos vetores adenovirais recombinantes em gradiente de cloreto de césio

3.18.3 Titulação de estoques de adenovírus recombinantes

3.18.4 Caracterização da expressão do produto transgênico por imunofluorescência após a infecção in vitro de células HEK293a

3.18.5 Imunização de camundongos com os adenovirus recombinantes gerados na presença ou na ausência da formulação adjuvante Poly (I:C) 
3.19 Resposta imune humoral contra as regiões variantes da CSP de $P$. vivax

3.19.1 Ensaios Imunoenzimáticos (ELISA) para detecção de anticorpos do tipo IgG total utilizando soros de camundongos imunizados

3.19.2 ELISA - subclasses de IgG

3.19.3 Imunofluorescência utilizando soros de camundongos imunizados com as proteínas recombinantes geradas na presença do adjuvante Poly(I:C)

3.20 Resposta imune celular estimulada com CSP de $P$. vivax. Medição da resposta imune mediada por linfócitos $\mathrm{T} \mathrm{CD4}^{+}$e $\mathrm{T} \mathrm{CD8}^{+}$ . .70

3.20.1 Peptídeos sintéticos. .70

3.20.2 ELISPOT 70

3.20.3 Isolamento de linfócitos, coloração na superfície celular e coloração intra-celular (ICS)

3.21 Análises estatísticas .72

4 RESULTADOS .73

4.1 Desenho dos genes sintéticos para expressão de proteínas recombinantes representando as diferentes variantes da CSP de Plasmodium vivax (PvCSP) em bactérias $E$. coli.

4.2 Expressão e purificação das proteínas recombinantes bacterianas representando as diferentes variantes alélicas da PvCSP

4.3 Imunogenicidade em camundongos imunizados com as diferentes formulações vacinais contendo as proteínas recombinantes representando as distintas formas alélicas da PvCSP.

4.4 Imunogenicidade dos adenovírus recombinantes, símio do tipo 68 e humano do tipo 5, deficientes em replicação, expressando as três regiões imunodominantes em fusão da CSP de Plasmodium vivax.

4.5 Indução da resposta imune celular contra a PvCSP após os regimes de vacinação homólogo ou heterólogo. 101

5 DISCUSSÃO. .105

6 CONCLUSÃO

REFERÊNCIAS

APÊNDICES. 
"TLR5-dependent immunogenicity of a recombinant fusion protein containing an immunodominant epitope of malarial circumsporozoite protein and the FliC flagellin of Salmonella Typhimurium." (Camacho et al.)

APÊNDICE B

"Immunogenicity of recombinant proteins consisting of Plasmodium vivax circumsporozoite protein allelic variant-derived epitopes fused with Salmonella enterica Serovar Typhimurium flagellin." (Leal et al.)

APÊNDICE C

"Immunogenicity of a prime-boost vaccine containing the circumsporozoite proteins of Plasmodium vivax in rodents" (Teixeira et al.)

APÊNDICE D

Patente - Plasmodium vivax Vaccine Compositions (27522-0201WO1) 
1 INTRODUÇÃO 


\subsection{Epidemiologia da malária causada pelo Plasmodium vivax}

Plasmodium vivax ( $P$. vivax) é uma das cinco espécies causadoras de malária em humanos. É uma espécie amplamente bem distribuída no mundo, sendo endêmica em aproximadamente 44 milhões de quilômetros quadrados, ou seja, um terço da superfície da Terra. Uma população estimada de aproximadamente 2,5 bilhões de pessoas vive em áreas de transmissão de malária vivax num total de 95 países. Estima-se que cerca de 71 a 391 milhões de casos clínicos ocorram anualmente distribuídos pelo mundo (John et al., 2012; Moon et al., 2012). Só em regiões onde as temperaturas permanecem muito mais baixas do que $16{ }^{\circ} \mathrm{C}$, ou, em regiões extremamente áridas, não ocorre à transmissão desta doença. Portanto, é uma espécie que merece significativa preocupação por ser um problema de saúde pública global. Entre os indivíduos considerados acometidos pela malária causada por esta espécie, e que estão distribuídos em áreas de alta endemicidade, $82 \%$ encontram-se na Ásia Central, 9\% no Sudeste da Ásia, 6\% nas Américas e 3\% na África. O mapa apresentado na figura 01 mostra a distribuição mundial da malária vivax em 2009, e não foram encontradas alterações nesta distribuição no ano de 2010 (Gething et al., 2012; Guerra et al., 2010; John et al., 2012).
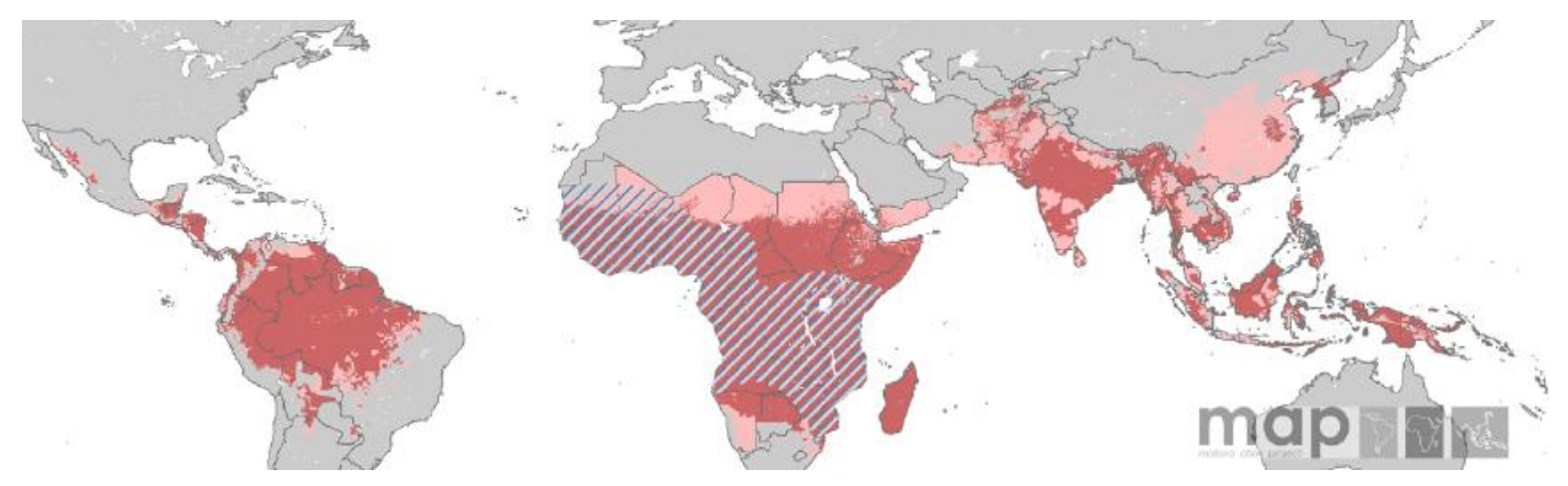

Figura 01: Distribuição mundial do Plasmodium vivax. Em vermelho, áreas consideradas de transmissão estável (onde a incidência anual de parasitos - IAP - a cada 1000 indivíduos é $\geq 0,1$ ); em rosa, áreas de transmissão instável (IAP $<0,1$ ); nas áreas achuradas da África há alta incidência de indivíduos com o tipo sanguíneo Duffy negativo; em cinza, áreas onde não há risco de transmissão (Guerra et al., 2010).

Excluindo o continente africano, os casos de malária causados pelo $P$. vivax chegam a $50 \%$ do total de casos (dados estimados no ano de 2012). A porcentagem destes casos foi distribuída da seguinte forma: $1 \%$ no continente Africano, $65 \%$ na região das Américas, $28 \%$ na 
região oriental do Mediterrâneo, $89 \%$ na região Europeia, 47\% no sudeste da Ásia, e $16 \%$ na região do Pacífico ocidental. Na tabela 02 está ilustrada a estimativa destes casos de malária, causados pelo $P$. vivax, a cada 1000 pessoas que vivem sob-risco (WHO, 2013).

Tabela 01: Número estimado de casos de malária causada pelo $P$. vivax no ano de 2012.

\begin{tabular}{|c|c|c|c|c|c|c|c|}
\hline \multirow{2}{*}{$\begin{array}{l}\text { a) } \\
\text { Region }\end{array}$} & \multicolumn{3}{|c|}{ Estimated cases ('000s) } & \multicolumn{3}{|c|}{ Estimated P. vivax cases ('000s) } & \multirow{2}{*}{$\begin{array}{c}\text { P. vvax as } \% \text { of tota } \\
\text { cases }\end{array}$} \\
\hline & Estimate & Lower & Upper & $\overline{\text { Estimate }}$ & Lower & Upper & \\
\hline African & 165000 & 93000 & 245000 & 1900 & 1600 & 2100 & $1 \%$ \\
\hline Region of the Americas & 800 & 700 & 1000 & 500 & 400 & 600 & $65 \%$ \\
\hline Eastern Mediterranean & 13000 & 10000 & 18000 & 3700 & 3000 & 4500 & $28 \%$ \\
\hline European & 2 & 2 & 2 & 2 & 2 & 2 & $89 \%$ \\
\hline South-East Asia & 27000 & 22000 & 33000 & 13000 & 10000 & 16000 & $47 \%$ \\
\hline Western Pacific & 1000 & 1000 & 2000 & 200 & 100 & 300 & $16 \%$ \\
\hline World & 207000 & 135000 & 287000 & 18900 & 16000 & 22200 & $9 \%$ \\
\hline Outside sub-Saharan Africa & 33300 & 28000 & 39400 & 16600 & 13800 & 19800 & $50 \%$ \\
\hline
\end{tabular}

\section{Fonte: WHO estimates - World Malaria Report 2013}

$\mathrm{O}$ maior interesse da pesquisa mundial sobre o combate à malária concentra-se em $P$. falciparum devido à mortalidade que provoca na África (Guerra et al., 2010).

Entretanto, os dados apresentados na tabela 01 demostra que a malária causada pelo $P$. vivax vem aumentando e se destacando, devido a evidências de que este parasito contribui para uma proporção significativa de doença grave e morte; e evidências da falha dos tratamentos quimioterápicos realizados contra a fase aguda da doença, e falha da terapia disponível contra as recidivas causadas pelos hipnozoítas. Portanto, esta doença é ainda um importante problema de saúde pública global que atinge as regiões mais populosas do mundo e que está se tornando cada vez mais bem documentada, necessitando de contínuos investimentos em controle e pesquisa (Gething et al., 2012).

\subsubsection{Malária no Brasil}

No Brasil, três espécies de Plasmodium são causadoras da malária: $P$. vivax, P. falciparum e P. malariae. P.vivax é a espécie mais prevalente, responsável por $83,7 \%$ dos casos registrados, $P$. falciparum causa $16,3 \%$ dos casos e $P$. malariae é responsável por uma mínima porção dos casos. Não há registros de casos de transmissão autóctone das outras duas espécies que causam malária no homem: P. ovale e $P$. knowlesi (Oliveira-Ferreira et al., 2010). 
A malária está concentrada na região da Bacia Amazônica que inclui os Estados do Acre, Amapá, Amazonas, Maranhão, Mato Grosso, Pará, Rondônia, Roraima e Tocantins, onde a característica ambiental destes locais favorece a transmissão. São os locais de maior endemicidade da doença no nosso país, onde ocorrem mais de $99 \%$ dos casos registrados. O principal vetor de transmissão da malária no Brasil é o mosquito da espécie Anopheles darlingi, encontrado em abundância. A incidência da doença é influenciada por diversos fatores, não só políticos, econômicos e sociais, mas também ecológicos e biológicos. Outros fatores que influenciam na prevalência da malária é a ausência de medidas de controle efetivas, por exemplo, vacinas seguras e eficazes (Tauil, 2011).

A incidência das duas principais espécies de Plasmodium transmitidas no Brasil se aproximou em 50\% cada, no ano de 1988. A figura 02 ilustra o número de casos registrados nos últimos 50 anos, segundo dados da Secretaria de Vigilância em Saúde, mostrando que os casos de malária causados pelo $P$. vivax disparou, e aumentou significativamente, permanecendo prevalente no país em relação aos casos relacionados com P. falciparum (Secretaria de Vigilância em Saúde, 2012).

Os dados mencionados em relação aos casos de malária no Brasil mostram que o aumento dos casos relacionados ao $P$. vivax segue em paralelo com o aumento da frequência das complicações clínicas incomuns de pacientes infectados com a mesma espécie de Plasmodium. Poucas drogas são utilizadas para tratamento, e a droga geralmente escolhida para o tratamento da doença causada por esta espécie, em áreas endêmicas, é a Cloroquina, porém existem evidências da ocorrência simultânea de malária grave e resistência a Cloroquina. Esta associação também foi avaliada no nosso país. Estudos realizados com pacientes infectados por $P$. vivax tratados somente com Cloroquina, na região Amazônica, revelaram 10\% de resistência a esta droga. Contudo, o uso de outra droga para tratamento, como a Mefloquina, sozinha ou em associação, se fez necessário, e mesmo esta droga ter se mostrado em outros países, como Indonésia e Nova Guiné, ser a solução para o problema de resistência a Cloroquina, foi relatado na Tailândia e no Brasil, na região Amazônica, resistência às duas drogas, Cloroquina e Mefloquina (Chehuan et al., 2013). 


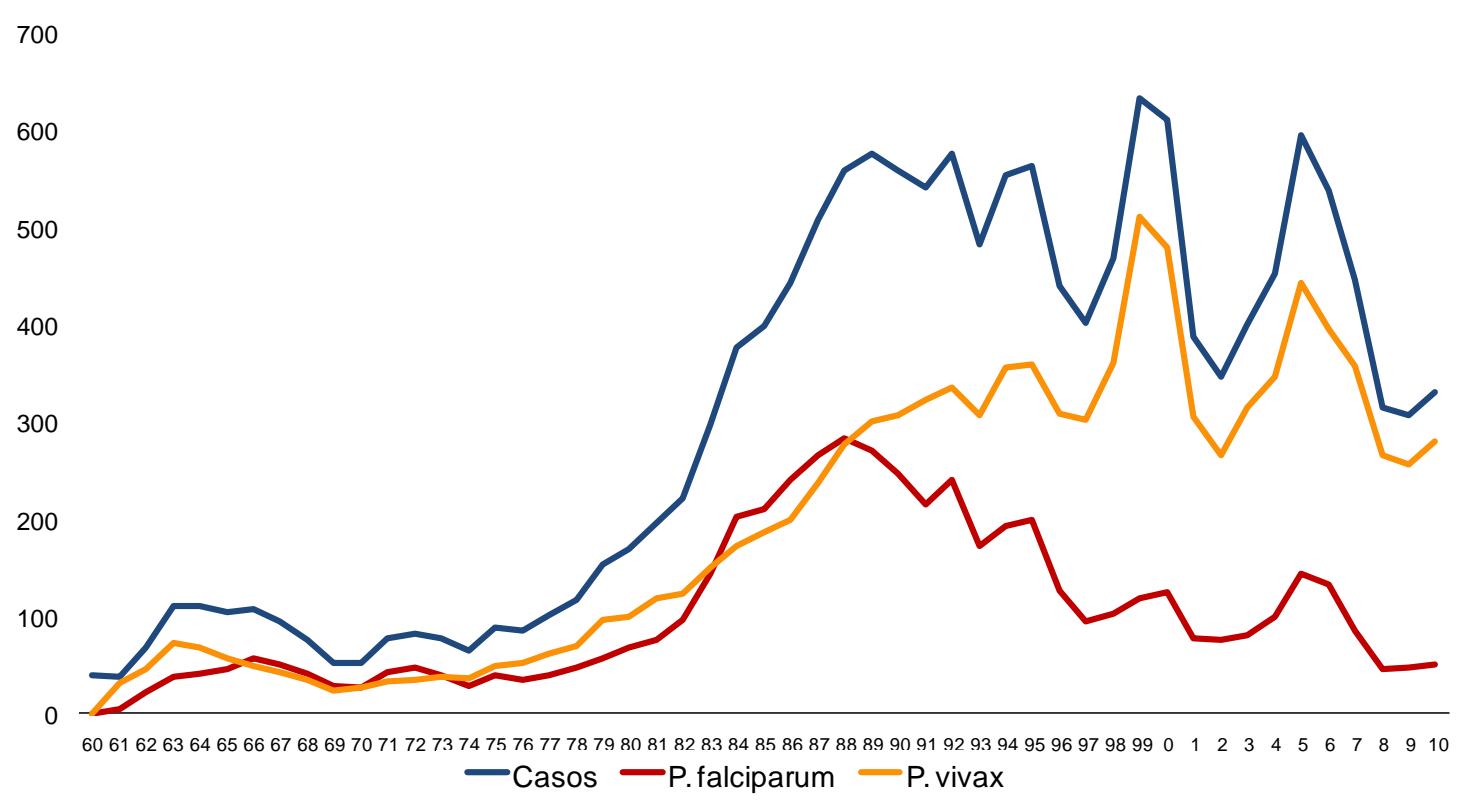

Figura 02: Número de casos de malária no Brasil, nos últimos 50 anos (1960 - 2010). Os números são estimados em até 700 mil casos. Em azul, números totais de casos de malária; em vermelho, números totais de casos de malária causados pelo $P$. falciparum; em amarelo, números totais de casos de malária causados pelo $P$. vivax.

Visando a eliminação da malária, que seria definida por ausência de casos autóctones numa área pré-determinada sem o uso de atividades de controle, qualquer medida de combate à doença ajudaria na redução da severidade e da mortalidade causada por ela. No Brasil, a eliminação da malária parece estar ainda distante, mesmo que nos últimos cinco anos o número de mortes causadas por esta enfermidade foi reduzido, ainda existe à presença de condições ideais para a transmissão desta doença, e à probabilidade de que indivíduos infectados provenientes de áreas endêmicas entrem em regiões não endêmicas e introduzam o parasito causador da doença (Tauil, 2011).

A atenção requerida ao $P$. vivax vem sendo aumentada devido seu destaque na saúde global, não só em relação às cepas resistentes ao tratamento com a Cloroquina, como já mencionado, mas também em relação às falhas nas estratégias de controle e eliminação do parasito. Portanto, o resumo de fatores que levam a necessidade de mais esforços nas pesquisas com o $P$. vivax são: ampla distribuição geográfica com maior número de indivíduos expostos a infecção; difícil controle; e as infecções podem também evoluir para síndromes clínicas graves (Guerra et al., 2010). 


\subsection{Biologia e ciclo de vida da malária}

A malária é causada por organismos eucarióticos unicelulares pertencentes ao gênero Plasmodium, que pertencem ao filo Apicomplexa, caracterizado pela presença de um complexo apical em sua extremidade anterior. O complexo apical é uma importante estrutura, pois contém organelas secretórias (róptrias e micronemas) capazes de secretar seus conteúdos durante o processo de invasão das células hospedeiras pelas formas esporozoítas e merozoítas do parasito. É transmitida exclusivamente através da picada de mosquitos fêmeas do gênero Anopheles infectados (Hafalla et al., 2011; Kappe et al., 2004; Mota, Rodriguez, 2004; Shanmugasundram et al., 2012). Cerca de 20 diferentes espécies do gênero Anopheles são importantes ao redor do mundo. Estes mosquitos picam o hospedeiro entre crepúsculo e o amanhecer. A intensidade da transmissão depende de fatores relacionados com o parasito, com o vetor, com o hospedeiro vertebrado e com o ambiente (WHO, 2011).

O parasito da malária humana apresenta um hospedeiro invertebrado definitivo (mosquito do gênero Anopheles), onde ocorre a fase sexual denominada esporogonia, e um hospedeiro vertebrado intermediário (homem), onde ocorre a fase assexual denominada esquizogonia. A figura 03 mostra o ciclo de vida do parasito, principalmente das espécies do $P$. vivax e $P$. ovale, pela indicação de hipnozoítas (Antinori et al., 2012; Hill, 2011).

Os parasitos do gênero Plasmodium codificam pelo menos 5600 genes e possuem um complexo ciclo de vida que inclui o crescimento assexuado intracelular obrigatório dentro dos hepatócitos de vertebrados (estágio pré-eritrocítico) e dos eritrócitos (estágio sanguíneo ou eritrocítico). A diferenciação sexual é iniciada no hospedeiro vertebrado enquanto a fusão dos gametócitos e a propagação do parasito via esporogonia ocorre no vetor mosquito (Hafalla et al., 2011).

Cinco espécies de Plasmodium são infecciosas para humanos: Plasmodium falciparum, Plasmodium vivax, Plasmodium malariae, Plasmodium ovale, e Plasmodium knowlesi, recentemente identificado como zoonose (Good, Doolan, 2010).

A jornada do esporozoíta inicia no intestino médio do mosquito hospedeiro e termina no hepatócito do hospedeiro mamífero. Esporozoítas se desenvolvem em oocistos, na parede do intestino médio do mosquito, e são liberados na hemocele onde são carregados pela hemolinfa para toda cavidade corpórea do mosquito, e por fim, se fixam nas glândulas salivares (Coppi et al., 2011). 


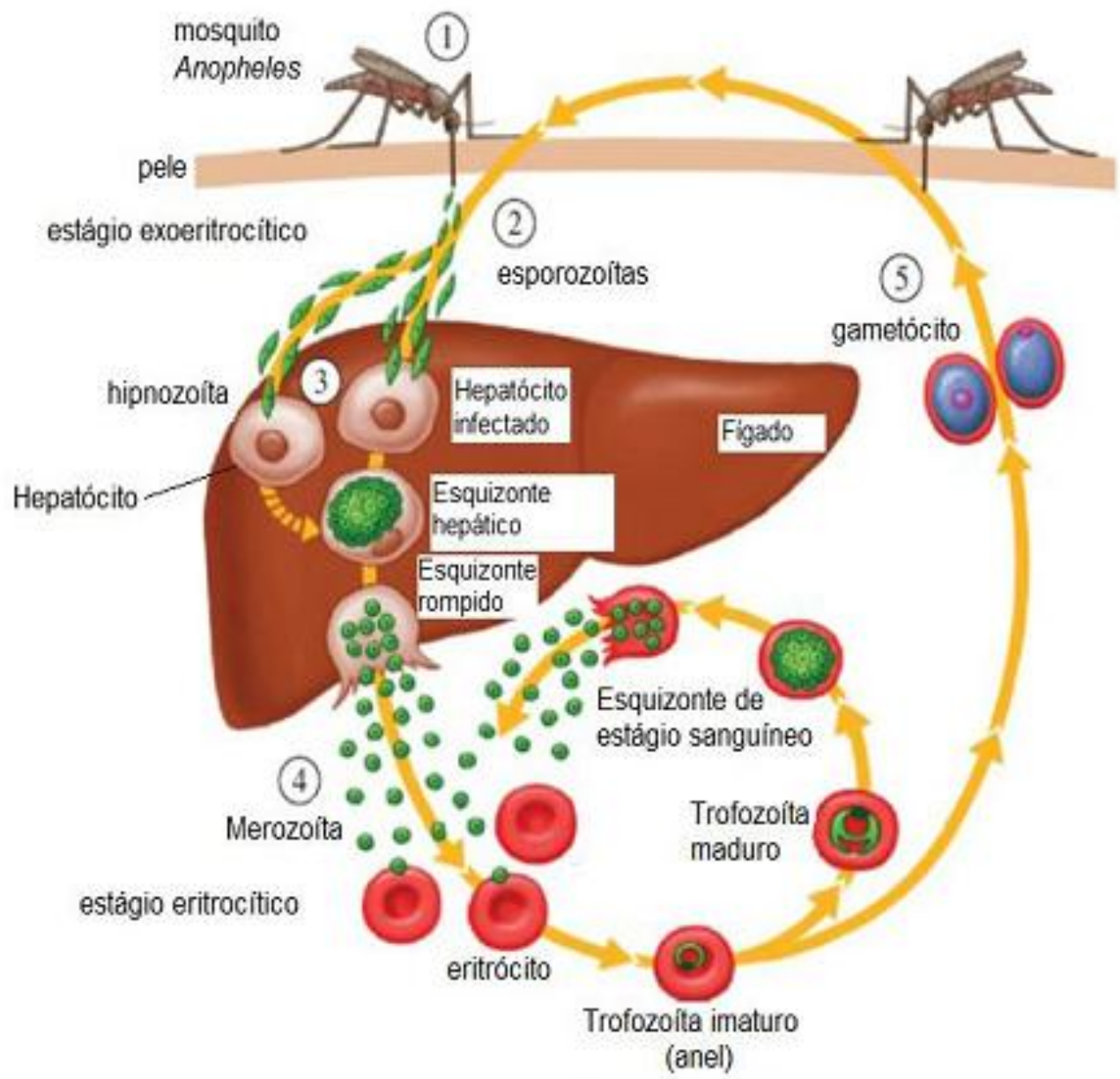

Figura 03: Ciclo de vida do Plasmodium vivax ou $\boldsymbol{P}$. ovale. (1) Mosquito faz o repasto sanguíneo e (2) injeta esporozoítas na derme do hospedeiro, e estes migram para o fígado; (3) esporozoítas invadem hepatócitos (estágio pré-eritrocítico); alguns esporozoítas formam hipnozoítas, e permanecem dormentes por até vários meses. (4) ruptura de hepatócito infectado, liberando merozoítas na corrente sanguínea, que infectam eritrócitos (estágio eritrocítico - ciclo assexuado do parasito); (5) parte dos merozoítas re-infectam eritrócitos, e parte dos merozoítas que re-infectaram se diferenciam em gametócitos, que são ingeridos pelos mosquitos, dando início ao ciclo sexuado do parasito. Figura retirada de (Hill, 2011).

Recentes estudos utilizando roedores mostraram que a maioria dos esporozoítas é injetada na derme, permanecendo no local por pelo menos 6 horas, com alguma migração para os vasos linfáticos proximais e linfonodos drenantes cutâneos, onde podem sobreviver por pelo menos 24 horas após a infecção. Esta fase inicial é denominada pré-eritrocítica, e clinicamente é silenciosa. Nos linfonodos drenantes cutâneos, a maioria dos esporozoítas é degradada mas alguns se desenvolvem parcialmente em formas exo-eritrocíticas. Os esporozoítas também podem se desenvolver em merozoítas na derme, na epiderme e nos folículos pilosos, onde podem 
sobreviver por dias ou semanas (Amino et al., 2006; Douradinha, Doolan, 2011; Menard et al., 2013). Esporozoítas deslizam suavemente na derme onde são vistos interagindo com a parede dos vasos sanguíneos, frequentemente diminuem sua velocidade para este deslizamento, antes de atingirem velocidades semelhantes a dos eritrócitos nos capilares dermais (Amino et al., 2006).

O estágio hepático do ciclo de vida foi documentado pela primeira vez em 1949 (Doolan, Hoffman, 1997). A infecção hepática causada por Plasmodium é a primeira fase obrigatória e clinicamente silenciosa do ciclo de vida do parasito, onde o hospedeiro tem tempo para montar uma resposta imune citotóxica para eliminar hepatócitos infectados. Estas características tornam o estágio hepático um alvo ideal para o desenvolvimento de novas estratégias de intervenção contra a infecção (Mota, Rodriguez, 2004).

Após invasão do fígado, cada esporozoíta sofre extensiva replicação dentro de um vacúolo parasitóforo cercado por uma membrana, e as proteínas do parasito com a porção Nterminal exportam elementos motivos que podem ser seletivamente transportados através da membrana vacuolar para o citoplasma de hepatócitos (Good, Doolan, 2010). As formas exoeritrocíticas se diferenciam em merozoítas através de esquizogonia. Estes merozoítas são liberados na corrente sanguínea periférica através de vesículas cheias de parasitos (merossomas) que utilizam a membrana da célula hospedeira como um cavalo de Tróia para escapar do sistema imune do hospedeiro (Douradinha, Doolan, 2011). O desenvolvimento do parasito, das diferentes espécies, no fígado humano dura aproximadamente de 7 a 10 dias, e de até 14 a 16 dias na infecção causada pelo $P$. malariae, e aproximadamente 2 dias no fígado dos camundongos (Menard et al., 2013).

Por volta de 1950, na Inglaterra estudos definitivos feitos por Shortt e Garnham identificaram o fígado como sítio do desenvolvimento pré-eritrocítico de malárias de primatas, em macacos Rhesus infectados por $P$. cynomolgi. Esta obra clássica ainda não identificava o estágio latente, embora depois do estudo realizado com primatas sugerisse que as recidivas poderiam surgir a partir do desenvolvimento de esquizontes hepáticos do estágio pré-eritrocítico. Quarenta anos mais tarde Krotoski, trabalhando com Garnham e seus colegas do Imperial College, finalmente identificaram as formas latentes ou "hipnozoítas" de P. cynomolgi e de $P$. vivax responsáveis por recidivas. Este termo é usado especificamente para descrever as recorrências de malária derivadas de estágios hepáticos persistentes do parasito (hipnozoítas), enquanto recrudescimento refere-se à reincidência de malária derivada da persistência da infecção do estágio sanguíneo. A recidiva surge após o "despertar" desses hipnozoítas com esquizogonia intra-hepática seguida do estágio sanguíneo. A pergunta sobre como os hipnozoítas 
são "despertados", e o que determina a sua periodicidade notável, permanece sem resposta (White, 2011).

Um único merozoíta invade um eritrócito, e, no caso dos dois mais comuns Plasmodia: $P$. falciparum e $P$. vivax, eles se submetem a um ciclo replicativo de 48 horas resultando em aproximadamente 16 novos merozoítas, resultado da ruptura de cada eritrócito. Desse modo, não há linfonodos drenantes para iniciar uma resposta imune ao estágio eritrocítico, mas o baço exerce um papel crítico sugerido por estudos realizados em humanos, macacos, e roedores (Good, Doolan, 2010).

Dentro dos eritrócitos, os merozoítas passam por um processo de diferenciação em trofozoítas, que sofrem divisões mitóticas e dão origem a esquizontes. Posteriormente, estes individualizam seus núcleos. O ciclo eritrocítico se fecha com a ruptura do eritrócito infectado e a invasão de outras células vermelhas pelos novos merozoítas formados. Cada ciclo eritrocítico tem duração de 48 a 72 horas, dando origem à "febre terçã ou quartã" - nome popular da malária - uma vez que, a cada ciclo, a ruptura em massa dos eritrócitos infectados causa o estado febril do indivíduo infectado (Bargieri, 2009).

Uma pequena parte dos merozoítas, ao invadir os eritrócitos, se diferencia por gametocitogênese em gametócitos, que são essenciais para garantir a continuidade do ciclo biológico do parasito. Alguns podem ser capturados por mosquitos após repasto sanguíneo. Os gametas masculinos sofrem ex-flagelação dando origem aos microgametas, que fecundam os macrogametas, gametócitos femininos, formando um zigoto (oocineto) diplóide que infecta o intestino médio do mosquito. $\mathrm{O}$ oocineto forma o oocisto que sofre esporogonia no intestino médio do mosquito liberando esporozoítas haplóides. Os esporozoítas infectam células das glândulas salivares do mosquito. Com a picada do mosquito, esporozoítas são inoculados na pele do hospedeiro vertebrado reiniciando o ciclo (Coppi et al., 2011; Hafalla et al., 2011).

\subsection{Patogenia e manifestações clínicas da malária}

A patogenia da malária é o resultado direto do ciclo de vida do parasito e da resposta inflamatória do hospedeiro. Em indivíduos residentes em áreas endêmicas, onde há contato contínuo com o parasito, a resposta inflamatória à infecção é diminuída, os sintomas são bastante atenuados, e podem desenvolver imunidade parcial. Em alguns casos a infecção é totalmente assintomática (Bargieri, 2009). As manifestações clínicas estão relacionadas com o ciclo sanguíneo da doença. Merozoítas invadem os eritrócitos, e o período de tempo que demora a estabelecer a infecção, desde a picada do mosquito até o aparecimento dos trofozoítas 
nos eritrócitos é conhecido como período pré-patente, que varia de acordo com a espécie. $\mathrm{O} P$. vivax apresenta tal período de 11 a 13 dias, já o $P$. falciparum, aproximadamente 9 dias. $\mathrm{O}$ paroxismo malárico se inicia através da ruptura dos eritrócitos devido aos esquizontes, caracterizado por um período febril clássico e divide-se em 3 estágios: 1) rápido aumento da temperatura corpórea associado a calafrios; 2) o pico de temperatura é atingido, há vasodilatação na pele, cefaleia e mialgias; 3) diminuição da temperatura (Antinori et al., 2012). Se não for tratada pode progredir para doença grave, muitas vezes levando à morte. Em infecções causadas pelo P. falciparum, o quadro clínico frequentemente evolui para malária grave. Nesses casos, a anemia é intensa, podendo haver comprometimento renal e respiratório, além de malária cerebral. Este quadro ocorre mais frequentemente em pacientes que não tiveram contato prévio com o parasito, ou seja, pacientes não imunes. Nestes, o parasito pode infectar mais de $15 \%$ dos eritrócitos circulantes, e estes podem aderir às paredes endoteliais, causando redução do fluxo da microcirculação, principalmente no cérebro (Bargieri, 2009).

Plasmodium falciparum é responsável pela maioria das mortes induzidas pela malária e a maior parte das morbidades associadas a esta doença, é, portanto, foco da maioria das pesquisas, porém estudos recentes realizados no sudeste asiático têm mostrado aproximadamente $25 \%$ de pacientes com malária severa associada à monoinfecção por $P$. vivax, com identificação de resistência a multi drogas. Assim, esforços substanciais estão agora direcionados para $P$. vivax. Na maioria das áreas onde a malária é endêmica, duas ou mais espécies de plasmódio coexistem e torna-se cada vez mais evidente que os parasitos diferentes coinfectam e interagem individualmente uns com os outros e exercem efeitos reguladores cruzados entre as espécies. Eliminar somente uma das espécies pode ter graves consequências clínicas potenciais e aumentar a prevalência da outra espécie parasita até então mantida sob controle (Good, Doolan, 2010).

Infecções mistas com as duas espécies, $P$. vivax e $P$. falciparum, são comuns. $P$. vivax é mais difícil de controlar e eliminar do que $P$. falciparum devido à sua tendência a recidivas após a cura da infecção primária, e o surgimento prévio de gametócitos. Em áreas endêmicas de malária vivax, a recidiva é uma das principais causas de malária em crianças pequenas, e uma importante fonte de transmissão da doença. Também ocorrem recidivas em infecções causadas por $P$. ovale e em várias malárias símias, como por $P$. cynomolgi, que tem sido frequentemente utilizado como um modelo animal de malária vivax. Os fatores que controlam recidivas e determinam sua periodicidade notável, não são conhecidos (White, 2011).

Entender a complicada interação que ocorre entre as espécies de Plasmodium e as células do hospedeiro não oferece somente uma nova perspectiva na biologia da célula do mamífero, 
mas também contribui para a concepção de abordagens racionais para combater a infecção causada pela malária (Mota, Rodriguez, 2004).

O $P$. vivax tem aparente preferência por invadir reticulócitos, enquanto que o $P$. falciparum invade eritrócitos mais velhos. Esta preferência seletiva para a invasão limita o crescimento de $P$. vivax tanto in vitro como in vivo (Price et al., 2007). A invasão de eritrócitos através de merozoítas é um processo que requer uma série de interações moleculares altamente específicas. Evidencia-se que o $P$. vivax precisa da interação da proteína Duffy (Duffy binding protein), que é um ligante de adesão do merozoíta, usada na invasão de reticulócitos humanos, que por sua vez, possuem o receptor para esta proteína (Duffy blood group - Fy) (Chenet et al., 2012).

O problema central para a fisiopatologia da malária falciparum é o seqüestro de eritrócitos, contendo as formas maduras do parasito na microcirculação dos órgãos vitais, o que faz com que o fluxo da microcirculação fique prejudicado e cause disfunção orgânica. Em contraste, reticulócitos infectados com $P$. vivax aparentemente não sequestram, e todas as fases do parasito podem ser encontradas na circulação do sangue periférico (Suwanarusk et al., 2004). Porém, evidências sugerem que mecanismos patogênicos importantes (como a citoaderência) podem ser compartilhados pelos dois parasitos, sendo que $P$. vivax citoadere menos do que $P$. falciparum (Carvalho et al., 2010).

$\mathrm{Na}$ última década pesquisadores mostraram que eritrócitos infectados com $P$. vivax amadurecem e são capazes de citoaderirem às células endoteliais e às células da placenta. Dois receptores utilizados por $P$. falciparum para a ligação às células endoteliais, ICAM-1 e CSA, também foram relacionados à citoadesão de parasitos $P$. vivax (Anstey et al., 2007; Carvalho et al., 2010). Portanto, um dos maiores achados recentes e importantíssimos em relação aos mecanismos da patogenia do P. vivax, foi a descoberta, através de ensaio ex vivo, de que reticulócitos infectados com este parasito são capazes de citoaderirem em células endoteliais do pulmão e na placenta. Porém os próximos desafios dos pesquisadores é tentar achar tal fenômeno através de ensaios in vivo (Lacerda et al., 2012).

As rosetas são outras formas conhecidas de citoadesão. Os eritrócitos parasitados aderem em outros eritrócitos não parasitados ou em plaquetas. Podemos encontrar três receptores associados à formação das rosetas: CR1 (receptor 1 do complemento), HS (Heparan Sulfato) e o Sistema sanguíneo ABO. As espécies $P$. falciparum, $P$. vivax e $P$. ovale são capazes de formar rosetas, porém, somente as rosetas formadas pelo $P$. falciparum estão associadas com malária severa, e o aumento de casos de obstrução microcirculatória, causada por estas rosetas, vem 
sendo relatado, principalmente em crianças africanas, já que a espécie prevalente na África é o $P$. falciparum (Autino et al., 2012).

Embora as infecções causadas por $P$. vivax tenham menor risco de morte para o indivíduo do que aquelas causadas pelo $P$. falciparum, a morbidade na infecção por $P$. vivax está associada com anemia e com uma resposta inflamatória pronunciada mediada por citocinas. O acúmulo diferencial de uma proporção de parasitos em alguns órgãos, tais como pulmões ou placenta, pode ser alvo da resposta inflamatória neste órgão, levando a uma apresentação clínica mais grave (Carvalho et al., 2010). Além da anemia severa, caracterizada por baixíssima taxa de hemoglobina, o indivíduo pode desenvolver trombocitopenia, caracterizada pelo baixo número de plaquetas, e é mais frequentemente encontrada em indivíduos infectados por $P$. vivax do que em $P$. falciparum. Está relacionada a distúrbios de coagulação, esplenomegalia, destruição de plaquetas por macrófagos, alterações na medula óssea, destruição de plaquetas mediada por anticorpos, estresse oxidativo e agregação de plaquetas. Outras complicações estão relacionadas com estresse respiratório e edema pulmonar, que podem estar associadas também com acidose metabólica, pneumonia e a síndrome respiratória aguda, que apresenta elevada taxa de mortalidade (Lacerda et al., 2012).

A grande quantidade de produtos do parasito e toxinas, quando são liberados no sangue, causa ativação da resposta imune inata através de mediadores inflamatórios, resultando nas febres, como sintoma da doença. Esta combinação de estresse circulatório, do sequestro dos eritrócitos e do excesso de resposta inflamatória, contribui para a maioria das manifestações severas da malária, incluindo a malária cerebral e anemia, porém, não limitando somente a estas (Autino et al., 2012). Por exemplo, a febre está relacionada com atividade pirogênica através da secreção de citocinas pelos fagócitos, que circulam e alteram o sistema termo regulador. Porém, quais moléculas, derivadas do parasito, estão envolvidas na liberação destas citocinas, e quais receptores estão envolvidos, para caracterizar esta atividade pirogênica, ainda não estão bem definidos. Assim, tem se assumido que a liberação de merozoítas ou algum resíduo da malária representam toxinas pirogênicas. Durante a fase intraeritrocítica, parasitos digerem a hemoglobina, resultando na produção de metabolitos da heme potencialmente tóxicos. Para se proteger contra danos oxidativos, o parasito desenvolveu um processo de desintoxicação que converte heme em um cristal insolúvel chamado hemozoína $(\mathrm{Hz})$. Com a elevada concentração de hemozoína, tem se sugerido que ela possa contribuir para as respostas imunes sistêmicas inflamatórias durante a infecção da malária, e sirva de transportadora para o DNA do parasito como consequência de estar associado a ela, sendo alvo do receptor tipo Toll, Toll-like receptor 9 (TLR9). Esta associação faz com que o DNA do parasito seja uma molécula altamente inflamatória levando a secreção de citocinas (Parroche et al., 2007). Acredita-se que outra toxina seja a âncora de GPI (glicosilfosfatidilinositol) que faz parte das proteínas que recobrem o parasito, e que ativam células 
hospedeiras principalmente através do receptor tipo Toll, Toll-like receptor 2 (TLR-2) (Parroche et al., 2007).

Ao longo de anos de batalhas contra a malária, várias questões dificultam o controle da doença causada pelo P. vivax. Enquanto as formas sexuais de P. falciparum, infectivas para o vetor invertebrado, aparecem tardiamente no curso da infecção, o mesmo não ocorre em $P$. vivax, uma vez que os gametócitos estão presentes nos primeiros dias da infecção, antes mesmo do tratamento ser iniciado dificultando o controle (Lacerda et al., 2012).

Além disso, outro fator que vem sendo relatado na última década, inclusive no Brasil, é que já existem evidências que o $P$. vivax utiliza outra via para invadir reticulócitos, através de outros receptores presentes nos reticulócitos de indivíduos que não apresentam o grupo sanguíneo Duffy. Anteriormente, acreditava-se que a presença da molécula Duffy era crítica para a invasão desta espécie de Plasmodium (Cavasini et al., 2007; Mendes et al., 2011).

Entretanto, a patogênese causada pelo $P$. vivax geralmente é multifatorial, e inclui a diversidade genética hospedeira, este fator dentre outros também contribui para a dificuldade de controle da doença. A resistência às drogas utilizadas no tratamento e as complicações que esta causa, também contribui para tal dificuldade. Ferramentas mais específicas para o diagnóstico de P. vivax, confirmando a mono-infecção e excluindo co-morbidades, são urgentemente necessárias para caracterizar o espectro real da malária vivax a nível mundial. Sem essas informações mais precisas, os ensaios clínicos de vacinas contra $P$. vivax não serão capazes de induzir proteção, por exemplo, contra a forma grave da doença, uma vez que a frequência destas manifestações mais severas já se assemelha a frequência destas causadas pelo $P$. falciparum, em áreas endêmicas da doença. $\mathrm{O}$ controle da malária só terá êxito se os dois parasitos forem tratados separadamente e não como causadores de uma única doença. Portanto, a caracterização clínica é o primeiro passo para, finalmente, planejar qualquer estratégia de controle em um futuro próximo (Lacerda et al., 2012).

\subsubsection{Resistência do P. vivax ao tratamento com Cloroquina}

A droga comumente utilizada contra as formas hipnozoítas e esquizontes hepáticos do $P$. vivax é a primaquina, que apesar da eficácia clínica é pobremente caracterizada. Esta droga é utilizada desde 1946, e é a única droga licenciada capaz de eliminar totalmente o $P$. vivax (John et al., 2012). Existem evidências de tratamento contra esquizontes de P. falciparum in vitro usando primaquina em associação com a cloroquina, uma vez que existe sinergia entre elas. Porém, ainda não foi relatada tal sinergia destas drogas quando utilizadas contra as formas 
eritrocíticas do P. vivax (Marques et al., 2013), sendo necessários outros estudos para avaliar a contribuição da cloroquina na associação com a primaquina, antes que qualquer conclusão definitiva seja proposta (Chehuan et al., 2013). Contudo, em áreas endêmicas do nosso país o tratamento da malária vivax sempre é feito com esta associação de cloroquina e primaquina. Porém, em alguns países, como no Brasil, devido algumas evidências, a resistência à cloroquina vem sendo associada com severidade clínica causada pelo P. vivax (Chehuan et al., 2013).

Entretanto, a cloroquina também é utilizada para o tratamento de casos de malária aguda causada pelo $P$. vivax, capaz de diminuir um dos principais sintomas desencadeado durante a fase eritrocítica do parasito, a febre, bem como diminuir a parasitemia com até $72 \mathrm{~h}$ após a administração da primeira dose da droga. A meia vida do medicamento é de $50 \mathrm{~h}$, e este permanece no sangue do paciente de 21 a 35 dias após o início do tratamento (Marques et al., 2013).

Os primeiros casos de resistência à cloroquina foram descritos em 1989 em indivíduos infectados na Papua Nova Guiné. Posteriormente, outros casos foram descritos no leste da Ásia, e evidências descritas na América do Sul. Mais precisamente em Manaus, aqui no Brasil, a primeira evidência clínica de resistência foi descrito no ano 2000. Na Colômbia foram descritos três casos, dentre 27 indivíduos, e no Peru quatro casos, dentre 177 indivíduos. No ano de 2007, dos 109 pacientes tratados com cloroquina, cerca de 10\% apresentaram resistência (Marques et al., 2013).

A resistência à droga favorece a recrudescência da doença, permitindo o reaparecimento da parasitemia, evidenciando a ineficiência do combate à doença contribuindo para o aumento de casos de malária severa causada pelo P. vivax (Marques et al., 2013).

\subsection{Mecanismos imunológicos contras as formas pré-eritrocíticas do Plasmodium sp e racional para o desenvolvimento de uma vacina contra malária baseado nestas}

Mecanismos imunes efetores contra estágios pré-eritrocítico do Plasmodium podem ser mediados através de anticorpos inibidores direcionados a antígenos de superfície do esporozoíta que bloqueiam a migração e a invasão de hepatócitos, bem como por células T $\mathrm{CD} 4^{+}$e $\mathrm{T}$ CD8 ${ }^{+}$ específicas, que eliminam parasitos intracelulares, diretamente através de citólise ou indiretamente através da produção de IFN- $\gamma$, que por sua vez ativa a via do óxido nítrico - NO (Hafalla et al., 2011). O bloqueio da infecção pela eliminação das formas pré-eritrocíticas levam a uma imunidade estéril assintomática e é, portanto, um objetivo importante para o controle da malária sem que haja a morbidade associada aos sintomas da doença (Figura 04). 
Esporozoítas são injetados intradermicamente durante o repasto sanguíneo do mosquito infectado. Eles se movem através da pele, atravessando as células. Talvez para relevância imunológica, nem todos os esporozoítas entram na circulação sanguínea. Imagens feitas através de microscopia intravital utilizando parasitos fluorescentes revelaram que uma proporção significante de parasitos permanece na derme, nos sítios de deposição, enquanto outros são drenados até um linfonodo proximal, onde ficam retidos, e servindo de fonte de antígenos para a ativação das respostas mediadas por células $\mathrm{T}$ e B. A maioria é encontrada com estreita associação às células dendríticas $\mathrm{CD} 1 \mathrm{c}^{+}$(Hafalla et al., 2011). As células dendríticas que residem nos linfonodos cutâneos são responsáveis por estimular as células T $\mathrm{CD}^{+}$específicas para antígenos da malária (Tsuji, 2010).

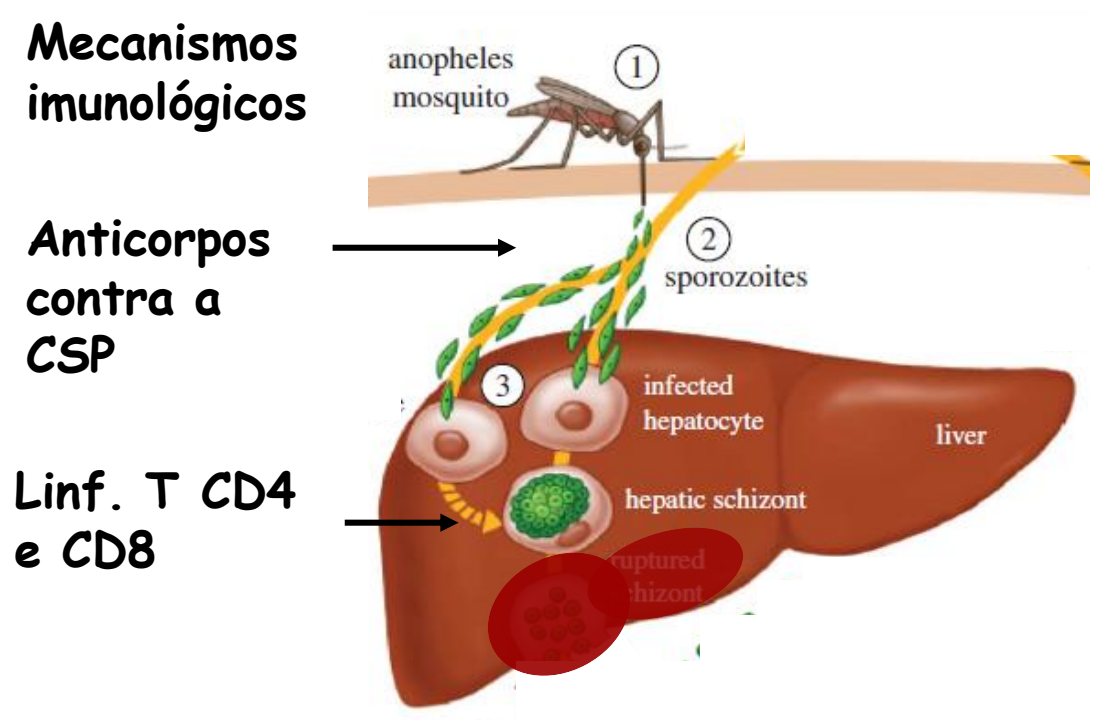

Figura 04: O esquema acima mostra os principais mecanismos que medeiam a imunidade contra as formas pré-eritrocítcas de malária.

A proteína de superfície circumsporozoíta (CSP), forma uma densa cobertura na superfície do parasito e é o principal alvo dos anticorpos que inibem a infectividade dos esporozoítas da malária. A estrutura geral, mas não a sequência primária, da CSP é altamente conservada entre as espécies de Plasmodium que infectam roedores, primatas, aves e homens. Esta proteína possui uma região central de aminoácidos repetidos, flanqueada por dois domínios conservados: região I, com uma sequência de 5 aminoácidos na porção $\mathrm{N}$ terminal, e um conhecido motivo de adesão às células, na porção C terminal, denominada TSR (repetição de 
trombospondina tipo I) (Coppi et al., 2011). Na figura 05 está esquematizada a proteína CS do Plasmodium sp (Kappe et al., 2004).

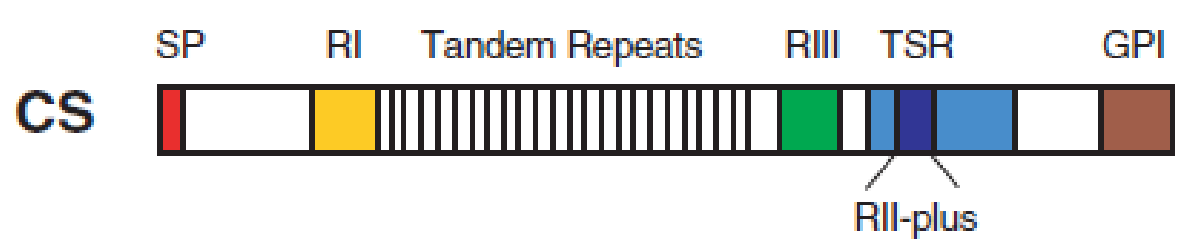

Figura 05: CSP exibindo seus diferentes domínios estruturais. SP- Peptídeo sinal; RI Região I; Tandem repeats - repetições de aminoácidos (epítopo imunodominante, alvo para linfócitos B); RIII - Região III; TSR - Type I Thrombospondin repeats/domínio de adesão celular, localizado na RII-plus - Região II; GPI - cauda de glicosilfosfatidilinositol.

As regiões centrais de repetição de aminoácidos da CSP das espécies de Plasmodium são alvos de anticorpos neutralizantes que estão envolvidos com vários mecanismos antiparasitários. Um aspecto importante da proteína CS de $P$. vivax é que ela apresenta três formas variantes genotípicas com distribuição mundial, e dentre elas, as duas variantes mais comuns, VK210 e VK247, exibem dois tipos principais de repetições de nonapeptídeos: GDRA (D/A) GQPA e ANGA (G/D)(N/D) QPG, respectivamente, nas suas regiões centrais (Arnot et al. 1985, Rosenberg et al.1989). Um terceiro tipo de repetições de aminoácidos caracteriza a chamada Vivax-like: APGANQ (E/G) GAA (Qari et al.,1993a).

Inicialmente, anticorpos neutralizantes agem reduzindo o inóculo e a viabilidade de esporozoítas durante a picada do inseto vetor. Usando roedores como modelos experimentais, foi descrito que complexos imunes são formados durante a picada do mosquito, reduzindo o número de esporozoítas depositado na derme (Kebaier et al., 2009). Os esporozoítas são processados por células dendríticas $\mathrm{CD} 11 \mathrm{c}$ e estimulam a ativação de linfócitos $\mathrm{T} C \mathrm{C} 8^{+}$no linfonodo drenante cutâneo. Estes linfócitos migram para o baço e fígado. No fígado estes linfócitos reconhecem os antígenos parasitários apresentados por hepatócitos infectados. Após o reconhecimento antigênico estes linfócitos eliminam estas células (Tsuji, 2010). E quando esporozoítas são inoculados pela via endovenosa, sem contato com a pele, anticorpos anti-CSP são capazes de bloquear eficientemente a infecção hepática. A inibição da infecção dos hepatócitos pode ser devido à redução da sua capacidade de migração e/ou adesão a estas células (Kappe et al., 2004). 
O papel crítico protetor das células $\mathrm{T} \mathrm{CD}^{+}$foi demonstrado em estudo de depleção e de transferência adotiva de clones de células $\mathrm{T}$ CD8 ${ }^{+}$específicas para o antígeno CSP feitos em modelo de roedores (Schofield et al., 1987; Tsuji, 2010; Weiss et al., 1988).

$\mathrm{O}$ papel das células $\mathrm{T} \mathrm{CD}^{+}$efetoras anti-malária foi demonstrado por estudos de transferência adotiva de clones destas células. Camundongos que receberam estas células foram resistentes ao desafio com esporozoítas e não desenvolveram malária. Como esta transferência adotiva falhou em conferir proteção contra infecção de estágios sanguíneos, pode ser concluído que estas células têm papel definido por mediar imunidade protetora contra estágios préeritrocíticos. Esta capacidade imuno-protetora é independente do perfil Th1 ou Th2 (Tsuji, 2010).

Consistente com os estudos de roedores, imunização de seres humanos com esporozoítas atenuados por irradiação (RAS) induziu células $\mathrm{T} \mathrm{CD}^{+}$e $\mathrm{TCD}^{+}$específicas para a CSP, secretoras de IFN- $\gamma$. Células $\mathrm{T} \mathrm{CD}^{+}$e $\mathrm{CD}^{+}$específicas para CSP, isoladas de voluntários imunizados com RAS de P. falciparum, protegidos, são capazes de lisar células autólogas pulsadas com peptídeos derivado da CSP in vitro. A capacidade destas células T $\mathrm{CD}^{+}$atuarem como células citotóxicas in vitro sugere que elas tenham potencial para eliminar hepatócitos infectados em seres humanos (Hafalla et al., 2011).

Apesar do foco inicial na CSP, existem outros antígenos alvos dos linfócitos T CD4 ${ }^{+} \mathrm{e}$ $\mathrm{CD}^{+}$imunoprotetores. Camundongos tolerantes à CSP ainda apresentam potente imunidade protetora após a vacinação com RAS. Também foi determinado que camundongos vacinados com RAS são resistentes a infecção com esporozoítas geneticamente modificados que expressam uma CSP de espécie não relacionada (Gruner et al., 2007; Kumar et al., 2006). De fato recentemente, outros antígenos das formas hepáticas têm sido descritos reconhecidos por linfócitos T CD8 ${ }^{+}$imuno-protetores (Hafalla et al., 2013; Murphy et al., 2013).

\subsection{Desenvolvimento de formulações vacinais contra os estágios pré-eritrocíticos da malária}

Especialistas em saúde pública concordam que o desenvolvimento de uma vacina efetiva contra malária seria uma ferramenta importante para o controle eficaz a longo prazo. Essa vacina deve ajudar as demais formas de intervenção disponíveis de saúde pública como a pulverização residual interna ou externa, mosquiteiros tratados com inseticida de longa duração e o tratamento preventivo intermitente para reduzir a morbidade e mortalidade causada pela malária (Friesen, Matuschewski, 2011). Além do uso para a eliminação da infecção por malária, o desenvolvimento de uma vacina moderna baseada na tecnologia do DNA recombinante exige 
novos conhecimentos que podem ser amplamente aplicáveis a outras infecções por vírus, bactérias, protozoários, fungos etc (Rappuoli, Medaglini, 2012).

Apesar da constante e crescente atividade de pesquisa, ainda não existe uma vacina capaz de impedir a infecção pelo Plasmodium spp. Entretanto, diversos estudos sugerem que a indução de uma imunidade protetora contra as formas pré-eritrocíticas da malária possa ser um objetivo tangível. As principais observações que corroboram com esta conclusão são: (i) imunizações com formas esporozoítas atenuadas por irradiação são capazes de induzir proteção assintomática em camundongos (Nussenzweig et al., 1967), em primatas não-humanos (Collins, Contacos, 1972) e no homem (Rieckmann et al., 1979); (ii) vacinações experimentais em modelos de infecções murinas demonstraram inequivocamente que compostos sintéticos e/ou recombinantes baseados na CSP recombinante são capazes de gerar potente imunidade protetora contra o desafio com P. berghei ou P. yoelii (Bruna-Romero et al., 2001; Li et al., 1993; Schneider et al., 1998; Tam et al., 1990; Tao et al., 2005); (iii) vacinações em crianças com uma proteína recombinante baseada na CSP de $P$. falciparum reduziu a incidência da doença durante a exposição natural ao plasmódio (Abdulla et al., 2008; Bejon et al., 2008; Collins, Barnwell, 2008).

Vacinas contra a malária são consideradas uma das modalidades mais importantes para a prevenção do potencial da doença e redução da transmissão da mesma. Pesquisas neste campo têm somado intensos esforços por muitos grupos ao longo das últimas duas décadas, principalmente para o desenvolvimento de vacinas contra o $P$. falciparum. Pesquisadores têm trabalhado em muitas abordagens para antecipar a disponibilidade de uma vacina contra a malária, não só contra $P$. falciparum, mas também contra $P$. vivax, que vem sendo destacado em inúmeros estudos desde a década de 50. Apesar disso, não há atualmente nenhuma vacina licenciada contra a malária. Contudo, merecem destaque dois candidatos vacinais de $P$. vivax, que dentre tantos outros testados em ensaios pré-clínicos, utilizando modelos murinos e símios, conseguiram sair na frente, e serem utilizados em formulações vacinais em estudos clínicos de fase I, conduzidos pela MVDC (Malaria Vaccine and Drug, Development Centre), em Cali, na Colômbia. As formulações vacinais contendo LSP (peptídeos sintéticos longos) representantes das regiões $\mathrm{N}$ e $\mathrm{C}$ terminal, e Central da proteína PvCS (considerados antígenos pré-eritrocíticos) ou a proteína recombinante Pvs25 (proteína de superfície de $25 \mathrm{KDa}$ de oocisto/oocineto), foram testadas na presença do adjuvante Montanide, e foram avaliadas a segurança e a imunogenicidade de cada formulação. 
A tabela 02 ilustra as diferentes formulações vacinais que atualmente estão sendo testadas por diversos pesquisadores no mundo, formuladas contra $P$. vivax, e que estão sendo testadas em testes pré-clínicos e clínicos (Arévalo-Herrera et al., 2010).

Tabela 02: Estudos desenvolvidos com candidatos antigênicos usados em formulações vacinais contra $P$. vivax.

\begin{tabular}{|c|c|c|c|c|c|c|}
\hline Parasite stage & Antigen & Type & Research & \multicolumn{2}{|c|}{ Pre-clinical } & $\begin{array}{l}\text { Clinical } \\
\text { Phase I }\end{array}$ \\
\hline \multirow{3}{*}{ Pre-Erythrocytic } & $\mathrm{CSP}^{2}-\mathrm{N}$ & LSP' & $Y^{n}$ & Y & Y & $Y$ \\
\hline & CSP-R & LSP & $Y$ & Y & $Y$ & $Y$ \\
\hline & CSP-C & LSP & Y & Y & $Y$ & $Y$ \\
\hline \multirow{4}{*}{ Asexual Erythrocytic } & MSP-I (200L) & $\operatorname{Rec}$ & $Y$ & $Y$ & $Y$ & $\mathrm{~N}$ \\
\hline & MSP-9 & $\operatorname{Rec}$ & $N^{i}$ & $Y$ & $\mathrm{~N}$ & $\mathrm{~N}$ \\
\hline & $\mathrm{DBP}^{d}-\mathrm{RII}$ & $\operatorname{Rec}$ & $Y$ & $Y$ & Y & $\mathrm{N}$ \\
\hline & $A M A^{=}-1$ & $\operatorname{Rec}$ & $Y$ & $\mathrm{~N}$ & $Y$ & $N$ \\
\hline Mixture & CSP, SSP2, AMAI, MSP-I & DNA & $Y$ & $\mathrm{~N}$ & $Y$ & $\mathrm{~N}$ \\
\hline
\end{tabular}

\subsubsection{Formulações vacinais contendo parasitos vivos atenuados: RAS (esporozoítas atenuados por radiação), GAP (parasitos atenuados geneticamente) e DAP (parasitos imobilizados por droga)}

Evidências experimentais sugerem que o uso de parasitos vivos atenuados, em formulações vacinais, pode levar a proteção de indivíduos contra vários antígenos. Estes parasitos têm servido como modelo para orientar o desenvolvimento de vacinas de subunidades. Nos últimos anos, a comunidade científica deu início a estudos pré-clínicos testando esporozoítas atenuados por radiação (RAS). Depois, foram os parasitos atenuados através de engenharia genética (GAS) que se destacaram, e o tratamento medicamentoso ou quimicamente modificado (DAP) que se apresentaram como vacinas potentes tanto em murinos como em humanos (Menard et al., 2013).

Desde a década de 60, pesquisadores demonstraram que era possível imunizar camundongos utilizando vacinas contendo esporozoítas vivos atenuados por radiação (RAS) de $P$. berghei e induzir proteção esterilizante contra o desafio do próprio parasito (Nussenzweig et 
al., 1967). Diversos estudos mais recentes mostraram que a imunização de indivíduos com RAS, também era possível (Epstein et al., 2007; Epstein et al., 2011; Hoffman et al., 2010).

Entre os anos 1972 e 1999, estudos envolvendo um total de aproximadamente 30 voluntários mostraram que uma média de 1.000 picadas de mosquitos infectados pelo $P$. falciparum irradiado, divididas entre 8 e 10 sessões ao longo de um programa de imunização de aproximadamente 10 meses, resultou na proteção de $90 \%$ dos indivíduos que foram expostos às picadas destes mosquitos infectados, entre um período de 5 e 10 semanas após a última imunização. Protegeu também indivíduos por até 10 meses, após a última imunização, quando estes receberam doses vacinais como reforços. Porém, este sistema de imunização, através de picadas de mosquitos infectados, não pode ser empregado como um sistema seguro de imunização em massa. Os esporozoítas deveriam, portanto, serem injetados por meio de seringas, através de uma via de administração clinicamente aprovada, como a subcutânea, a intradérmica ou a intramuscular, pois a intravenosa é a menos suscetível de ser aprovada para este tipo de imunização (Menard et al., 2013).

Em 2003, foi criada a empresa Sanaria Inc. para fabricar esporozoítas de P. falciparum atenuados por radiação (RAS) e criopreservados, para serem utilizados em vacinação humana contra malária (Menard et al., 2013). Atualmente, existe uma vacina produzida por esta empresa contra P. falciparum, conhecida por PfSPZ, que está sendo utilizada em estudos clínicos de fase I/IIa, porém, seus resultados iniciais demonstraram baixos níveis de proteção contra a infecção deste parasito (Epstein et al., 2011).

Um estudo publicado recentemente mostrou que a imunização com cinco doses vacinais com $>10^{5}$ RAS criopreservados injetado pela via endovenosa protegeu $100 \%$ dos indivíduos após desafio feito pela picada de 5 mosquitos infectados com P. falciparum (Seder et al., 2013).

Também recentemente, indivíduos que receberam vacinas contendo esporozoítas selvagens que foram submetidos à Cloroquina (DAP - parasitos imobilizados por droga), ficaram protegidos após desafio com esporozoítas de P. falciparum, pois esta vacina confere imunidade pré-eritrocítica, não protegendo os indivíduos contra desafio com as formas sanguíneas do parasito (Menard et al., 2013).

No entanto, o uso de esporozoítas vivos e viáveis atenuados por radiação impõe restrições, porque se a radiação falhar estes parasitos provocariam a doença, anulando assim quaisquer efeitos protetores. Para definitivamente resolver este problema, na última década, outra estratégia experimental tem sido testada em modelo murino, a imunização com parasitos atenuados geneticamente (GAP), onde ocorre o silenciamento de genes expressos no estágio préeritrocítico destes parasitos. Como estes genes são expressos no estágio pré-eritrocítico são, 
portanto, capazes de induzir potente imunidade contra o desafio experimental utilizando esporozoítas (Butler et al., 2011; Mueller et al., 2005), pois, os esporozoítas são bloqueados logo após invasão dos hepatócitos fornecendo proteção semelhante ou um pouco menor do que a conferida pelos RAS (Menard et al., 2013). Estes parasitos geneticamente atenuados estão sendo agora explorados como possíveis fontes antigênicas para o desenvolvimento de vacinas para humanos. Infelizmente, os primeiros estudos de fase I e II demonstraram que em alguns pacientes imunizados houve reversão do fenótipo de atenuação e os esporozoítas infectaram os indivíduos (Spring et al., 2013).

Mesmo que estudos mostrem resultados eficientes, o uso destas vacinas vivas atenuadas apresentam problemas operacionais. A questão da dificuldade em se manter estes parasitos vivos e a questão da via de inoculação endovenosa que nunca é utilizada para a administração de vacinas precisam ser resolvidas para que elas possam ser utilizadas em ensaios clínicos (Bargieri et al., 2011).

\subsection{Estratégias usando formulações vacinais recombinantes de subunidades contra malária: antígenos pré-eritrocíticos}

\subsubsection{Vacina RTS,S}

Boa parte das atividades de pesquisa na área de malária estão direcionadas à geração de vacinas recombinantes de subunidades. Estudos experimentais utilizando modelos animais serviram como base para estudos clínicos em humanos através do uso de formulações vacinais contendo subunidades (Bargieri et al., 2011; Douradinha, Doolan, 2011). As vacinas de subunidades recombinantes mais utilizadas em estudos experimentais são aquelas formuladas com proteínas recombinantes em sistemas adjuvantes, bem como vacinas utilizando vetores virais recombinantes.

Desde 1984 a Glaxo Smith Kline Biologicals (GSK) e o Walter Reed Army Institute of Research vêm trabalhando em parceria para desenvolver uma vacina contra a malária para proteger bebês e crianças que vivem em regiões endêmicas de malária na África subsaariana. Com este intuito, neste período foi desenvolvida a formulação RTS,S/AS®. Esta formulação vacinal contém repetições de aminoácidos da região central e parte de um fragmento da região C-terminal da proteína CS, de $P$. falciparum, em fusão ao antígeno $\mathrm{S}$ do vírus causador da hepatite B (vacina convencional contra hepatite B, Engerix B®). Plasmídeos codificando genes para tal fusão mencionada, e plasmídeos codificando genes do antígeno $\mathrm{S}$ do vírus causador da 
hepatite B são cultivados na levedura Saccharomyces cerevisiae, que monta naturalmente partículas semelhantes a vírus (VLP - virus-like particles), originando a RTS,S. A eficácia da formulação RTS,S foi testada na presença de sistemas de adjuvantes (AS). Há duas diferentes formulações adjuvantes sendo testadas com a RTS,S que incluem, monofosforil lipídio A (MPL A) e QS21 (saponina purificada de Quillaja saponaria) em uma emulsão de óleo em água (AS02) ou em suspensão lipossomal (AS01). Estas formulações foram avaliadas em testes clínicos de fase I/II, e os estudos mostraram que possuem um perfil de segurança e imunogenicidade favorável.

Entretanto, a vacina RTS,S/AS01 foi submetida ao ensaio clínico de fase III, para avaliar sua eficácia em crianças de diferentes regiões de transmissão da malária na África, que é essencial para o seu licenciamento definitivo (figura 06).

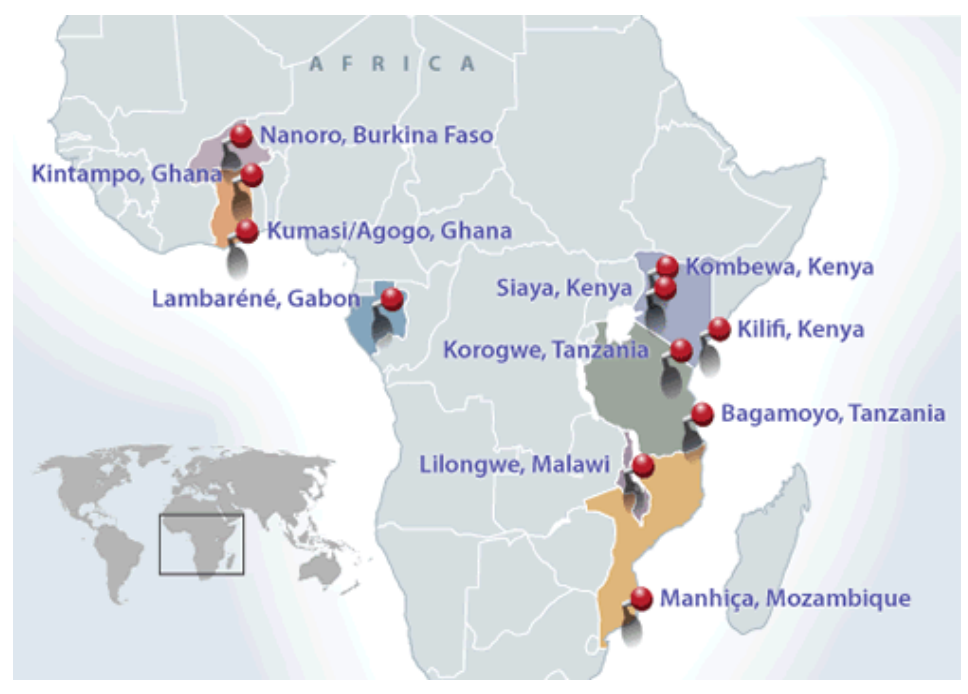

Figura 06: Diferentes regiões da África selecionadas para o teste clínico de fase III da RTS,S/AS01. População total: 15.460 crianças, sendo 8.923 de 5 a 17 meses e 6.537 de 6 a 12 semanas. Período de vacinação: 26 de Maio de 2009 a 31 de Janeiro de 2011 (PATH - MVI, 2014).

Os resultados preliminares obtidos com esta vacina, RTS,S/AS01, mostraram que ela foi capaz de conferir imunidade contra infecção natural pelo $P$. falciparum medida pela redução da incidência da doença e, apresentaram eficácia estatisticamente significativa de 50,4\% (intervalo de confiança - IC $95 \%$ de $45,8 \%$ a 54,6\%), retardando o primeiro episódio de malária em crianças de 5 a 17 meses de idade durante o período estudado. A eficácia vacinal contra malária 
severa foi de 34,8\% (IC 95\% variando de 16,2\% a 49,2\% (figura 07) (Agnandji et al., 2011; Leach et al., 2011).

Recentemente, resultados obtidos deste ensaio clínico de fase III realizado com crianças de 6 a 12 semanas de vida foram apresentados. Houve retardo nos primeiros casos de malária, estatisticamente significativo, com uma eficácia de 30,1\% (IC 95\% variando de 23,6\% a 36,1\%), e eficácia vacinal contra malária severa de 26,0\% (IC 95\% variando de 7,4\% a 48,6\% (figura 08) (Agnandji et al., 2012).

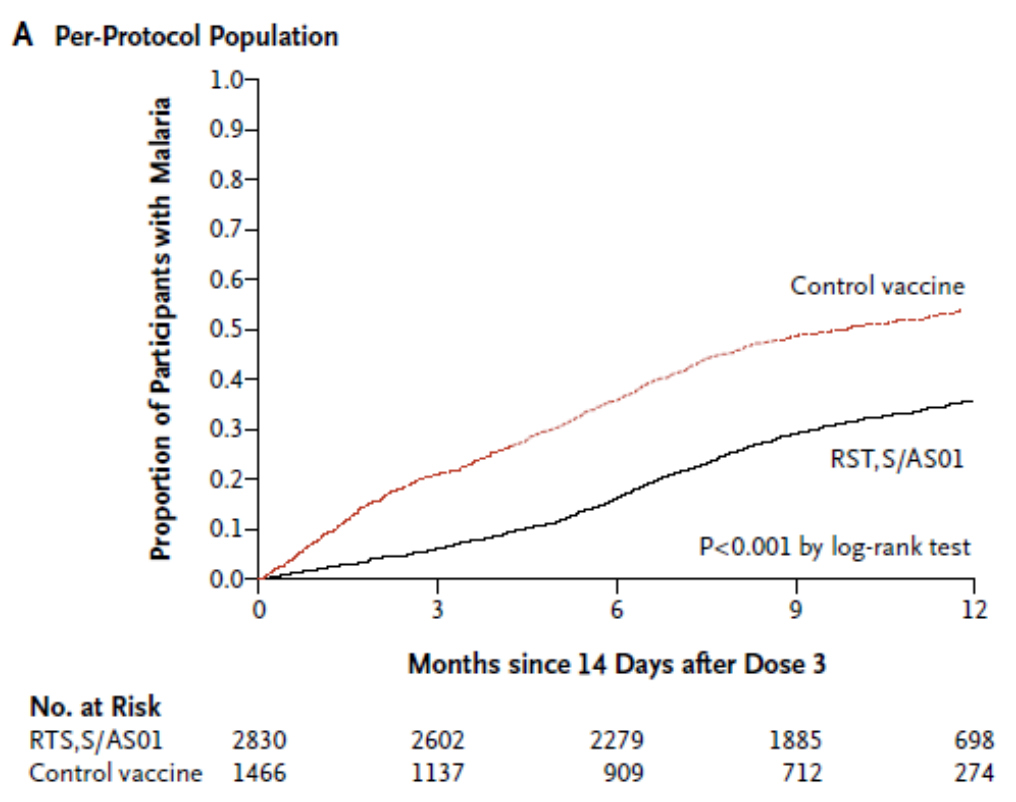

Figura 07: Resultados preliminares da eficácia da vacinação com a formulação RTS,S/AS01 (Agnandji et al., 2011). 
A Per-Protocol Population

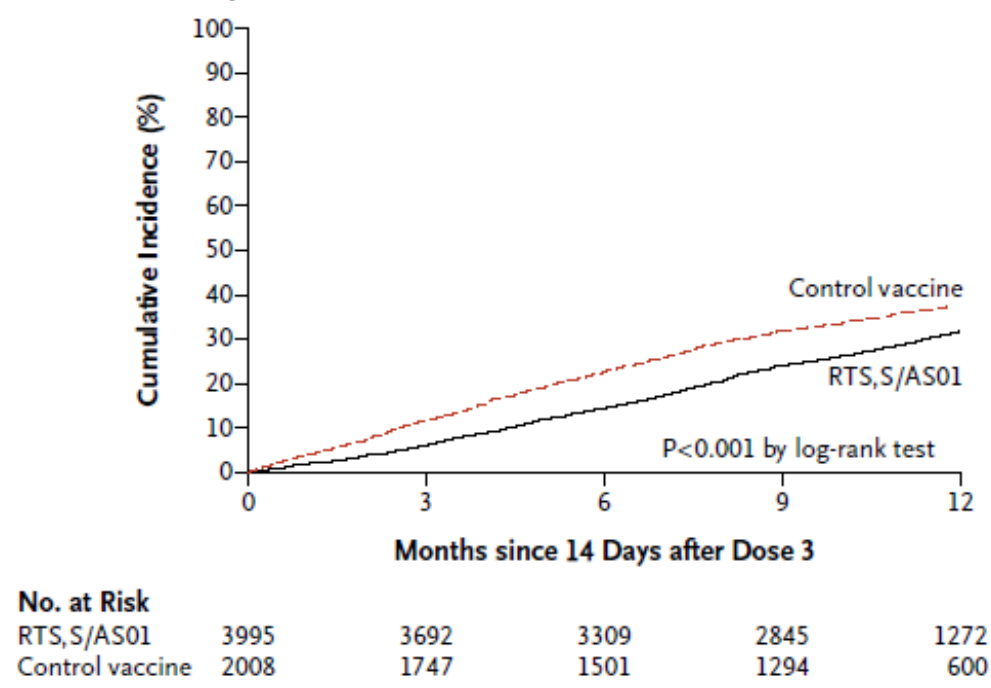

Figura 08: Eficácia da vacinação com a formulação RTS,S/AS01 em ensaio clínico de fase III (Agnandji et al., 2012).

Os estudos dos possíveis correlatos de proteção observados nestas crianças, e realizados a partir de 6 meses após a primeira dose vacinal, apontou para a concentração sérica de anticorpos contra a região imunodominante da CSP de P. falciparum (figura 09) (Olotu, Lusingu et al., 2011). De acordo com estudos epidemiológicos, foi recentemente descrito que administração profilática de anticorpos monoclonais anti-CSP obtidos de indivíduos vacinados com a formulação RTS,S/AS01E protegeu camundongos, humanizados (desenvolvidos com hepatócitos humanos funcionais), do desafio contra esporozoítas pela via i.v. ou pela picada de mosquitos infectados por $P$. falciparum. Os títulos de anti-CSP que transmitiram proteção integral estavam dentro da faixa observada em indivíduos vacinados com a RTS,S (Foquet, Hermsen et al., 2013).

A imunidade desenvolvida através da administração da vacina RTS,S/AS01E foi acompanhada pelo período de 4 anos num grupo de crianças de 5 a 17 meses. A eficácia foi de $43,6 \%$ (IC $95 \%$ variando de $15,5 \%$ a $62,3 \%$ ) no primeiro ano e decaiu para $0,4 \%$ (IC $95 \%$ variando de $32,1 \%$ a 45,3\%) no quarto ano (Olotu, Fegan et al., 2013).

Os resultados destes estudos clínicos de fase III têm causado grande impacto. As últimas etapas de testes estão sendo realizadas com esta vacina, RTS,S/AS, e se confirmarem os resultados anteriores, em 2015 será submetida ao pedido de linceciamente definitivo à Agência Europeia de Medicamentos e à Organização Mundial de Saúde (PATH-MVI, 2014). 

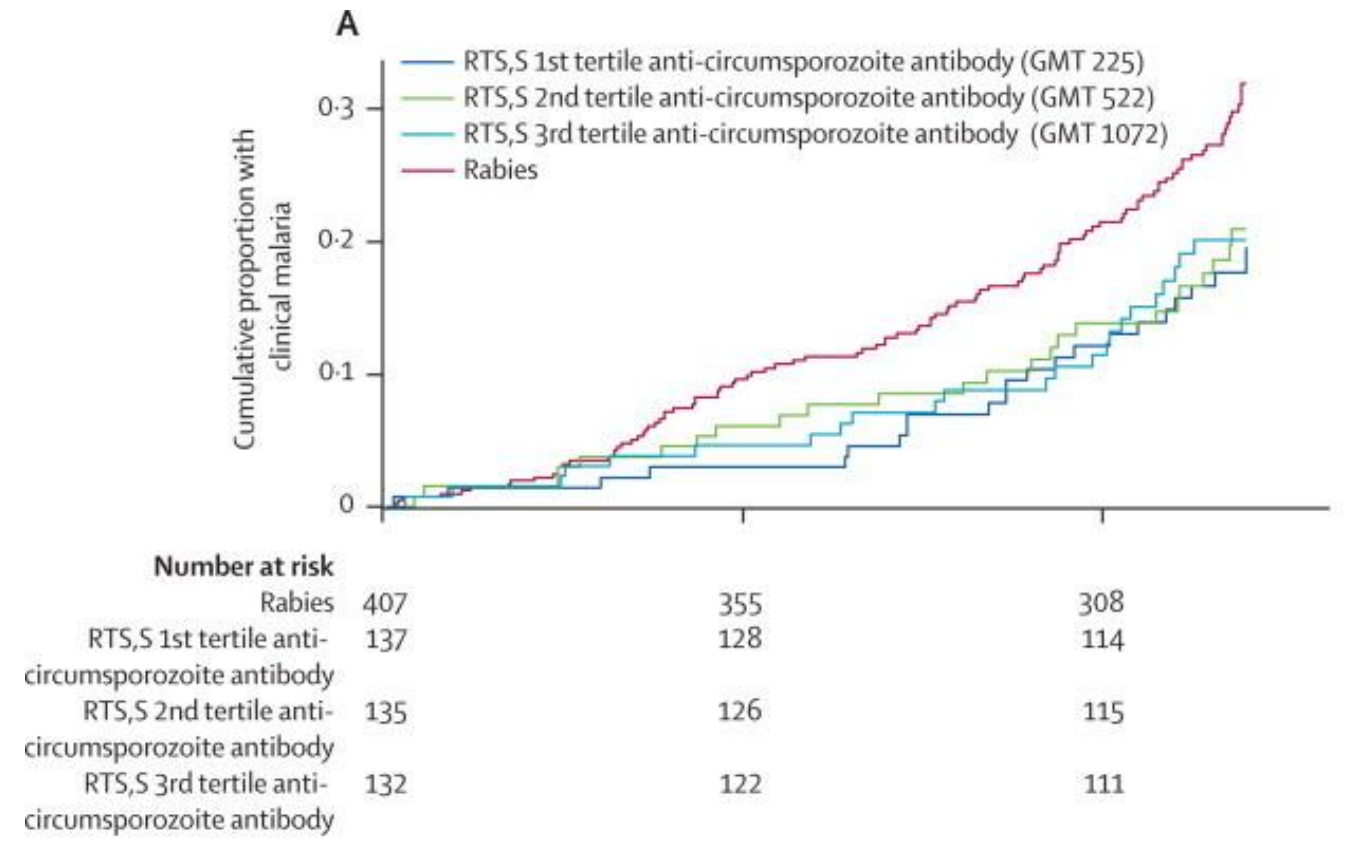

B

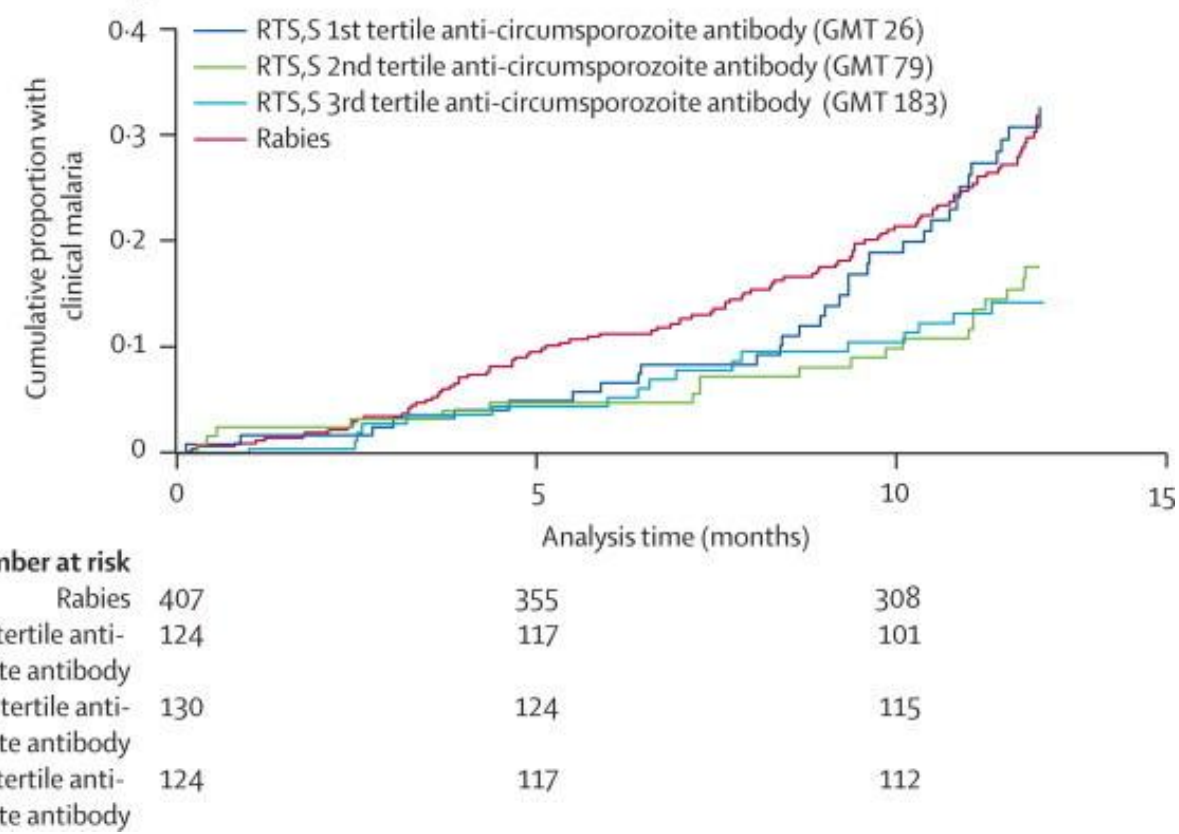

Figura 09: Concentração sérica de anticorpos específicos contra a região imunodominante da CSP de $P$. falciparum é importante para a eficácia da vacinação com a formulação RTS,S/AS01 (Olotu et al., 2011; Olotu et al., 2011). Em A, mostra que a eficácia da vacinação com a formulação RTS,S/AS01 é independe da concentração sérica de anticorpos específicos detectados 1 mês após a terceira dose vacinal. Já em B, pode ser observado que a eficácia da vacinação com a formulação RTS,S/AS01 depende da concentração sérica de anticorpos específicos detectados 5-6 meses após a primeira dose vacinal. 


\subsubsection{Vacina VMP001}

No caso específico do P. vivax, as pesquisas focando no desenvolvimento de uma vacina recombinante proteica contra as formas pré-eritrocíticas desta espécie têm sido limitadas primariamente pela dificuldade de se obter um número suficiente de parasitos - uma vez que não dispomos de um sistema eficiente de cultivo do P. vivax. Nos últimos 10 anos, houve apenas estudos de imunogenicidade. A maioria foi feito em camundongos, um foi feito em primatas e somente dois ensaio clínicos de fase I foram feitos em voluntários.

A maioria dos estudos feitos em camundongos e primatas utilizou uma proteína recombinante gerada em E. coli. Esta proteína contém na sua estrutura principal a região repetida representando o alelo VK210 da proteína CSP de $P$. vivax, e algumas repetições representado o alelo VK247 e foi denominada VMP001. Esta proteína foi imunogênica quando administrada em diferentes formulações vacinais sendo capaz de induzir resposta imune mediada por anticorpos e linfócitos T CD4 ${ }^{+}$(Bell et al., 2009; Lumsden et al., 2012; Moon et al., 2012; Yadava et al., 2007;). Por fim, os autores demonstraram que esta proteína também foi capaz de induzir imunidade cruzada parcial contra a infecção experimental de camundongos desafiados com o $P$. berghei (Yadava et al., 2012).

Os ensaios clínicos de fase I foram realizados há bastante tempo e utilizaram uma proteína recombinante produzida em bactéria e outra produzida em levedura. Nos dois casos as proteínas foram administradas acopladas ao adjuvante comercial alum (Gordon et al., 1990; Herrington et al., 1991). Ambas as formulações foram pouco imunogênicas e os estudos foram descontinuados.

\subsubsection{Vacina formulada com peptídeos sintéticos - LSP}

Foram relatados estudos utilizando peptídeos sintéticos longos com sequências representando a proteína CS de P. vivax como plataforma para o estudo do desenvolvimento de uma vacina sintética contra malária (Corradin et al., 2012). Estes peptídeos foram testados em ensaios clínicos de fase I em voluntários. Os peptídeos representavam as porções N- ou Cterminal, ou as repetições de aminoácidos da região central da proteína PvCS variante VK210. Estes peptídeos foram administrados pela via intramuscular na presença do adjuvante veterinário Montanide ISA 720. Os resultados demonstraram boa segurança e tolerabilidade para esta formulação vacinal. Os indivíduos também desenvolveram anticorpos específicos contra as três diferentes regiões da proteína CS e linfócitos produtores de IFN- $\gamma$ (Arevalo-Herrera et al., 2011). 


\subsection{Vetores virais}

Estudos realizados no final da década de 80 e começo da década de 90 demonstraram a importância da imunidade celular em proporcionar proteção contra o estágio hepático do parasito causador da malária em modelos animais (Bargieri et al., 2011). Para induzir imunidade celular significativa foi proposta uma nova abordagem utilizando imunização e reforço com dois vetores distintos, posteriormente denominada prime-boost heterólogo (Hill, 2011; Vasconcelos et al., 2012).

Alguns vetores virais defeituosos nos genes de replicação, como adenovírus humano tipo 5 e adenovírus de chimpanzé tipo 63 ou 68, e o vírus modificado Ankara (MVA) têm sido usados em sistemas de vacinação do tipo prime-boost heterólogo contra malária. Dois estudos recentemente publicados, realizados pelo exército americano e pela Universidade de Oxford, obtiveram resultados promissores em estudos de fase IIa/b. No primeiro estudo, indivíduos receberam três doses mensais de uma vacina formulada com dois plasmídeos recombinantes contendo genes que codificam os antíngenos CSP e AMA 1 (Apical Membrane 1) de $P$. falciparum. Estes indivíduos receberam como reforço uma mistura de dois vetores adenovirais recombinantes de humanos do tipo 5 também contendo estes mesmos genes. Quatro de quinze indivíduos que foram desafiados experimentalmente através da exposição à mosquitos infectados com P. falciparum, foram resistentes à infecção (Chuang et al., 2013).

No segundo estudo, indivíduos foram imunizados inicialmente com vetores adenovirais recombinantes de chimpanzé do tipo 63 contendo uma construção genética artificial denominada ME-TRAP. Os indivíduos receberam como reforço MVA recombinante contendo este mesmo gene. Após exposição à mosquitos infectados com $P$. falciparum, 3 de 14 indivíduos foram resistentes à infecção. $\mathrm{O}$ correlato de proteção foi atribuído às células $\mathrm{T} \mathrm{CD} 8^{+}$específicas para o antígeno, produtoras de INF- $\gamma$, porém não houve tal atribuição à anticorpos (Ewer et al., 2013).

Estes resultados apontam para a possibilidade de se utilizar a vacinação genética capaz de induzir potente imunidade mediada por linfócitos T como uma estratégia para a vacinação contra malária. 
2 OBJETIVOS 


\subsection{Objetivo geral}

Gerar formulações vacinais recombinantes baseadas na CSP que possam ser candidatas ao desenvolvimento de uma vacina universal e eficaz contra malária causada pelo $P$. vivax.

\subsection{Objetivos específicos}

- Geração e purificação de três proteínas recombinantes bacterianas baseadas nas sequências primárias que representam as diferentes formas alélicas da CSP do P. vivax;

- Geração e purificação de uma quarta proteína recombinante bacteriana contendo as sequências primárias que representam as diferentes formas alélicas da CSP do $P$. vivax em fusão num mesmo polipeptídeo;

- Estudo das propriedades imunogênicas em camundongos das quatro diferentes proteínas recombinantes administradas individualmente ou como uma mistura, na presença de diferentes adjuvantes;

- Geração de adenovírus recombinantes símio e humano deficientes em replicação contendo as sequências primárias que representam as diferentes formas alélicas da CSP do $P$. vivax em fusão num mesmo polipeptídeo;

- Estudo das propriedades imunogênicas destes adenovírus recombinantes para utilização em regimes de vacinação e reforço (prime-boost) heterólogo. 
3 MATERIAIS E MÉTODOS 


\subsection{Composição das soluções e tampões utilizados}

- TAE (1X): Tris-acetato $40 \mathrm{mM}$, EDTA $1 \mathrm{mM}, \mathrm{pH} 8,0$.

- TE: Tris-EDTA buffer, Tris-HCl 10 mM, EDTA 1 mM, pH 8,0.

- Gel de agarose: agarose 2\%, TAE (1X), brometo de etídio (1 $\mu \mathrm{g} / \mathrm{ml}$, Sigma).

- Gel de poliacrilamida para eletroforese de proteínas (SDS-PAGE):

Gel de corrida: Acrilamida 30\%, Bis acrilamida 0,8\%, Tris base 0,75 M, SDS 0,2\%, pH 8,8, Persulfato de amônio $10 \%$, Temed $10 \mu \mathrm{L}$.

Gel de separação: Acrilamida 12\%, Bis acrilamida 1,2\%, Tris base 0,25 M, SDS 0,2\% pH 6,8, Persulfato de amônio $10 \%$, Temed $10 \mu \mathrm{L}$.

- Tampão de corrida: SDS 0,1\%, glicina 192 mM, Tris base 25 mM, pH 8,3.

- Solução corante (Coomassie blue): Coomassie blue R 250 0,05\%, metanol 45\%, ácido acético $10 \%$.

- Solução descorante: metanol 45\%, ácido acético $10 \%, \mathrm{H}_{2} \mathrm{O}$.

- PBS: $\mathrm{NaH}_{2} \mathrm{PO}_{4} 10 \mathrm{mM}, \mathrm{KCl}, \mathrm{KH}_{2} \mathrm{PO}_{4}, \mathrm{NaCl} 150 \mathrm{mM}, \mathrm{H}_{2} \mathrm{O}, \mathrm{pH}$ 7,4.

- Solução Bloqueio PBS/Leite/BSA: PBS 1X acrescido de 5\% de leite desnatado (Molico) e 2\% de BSA (Sigma).

- PBS-T20 (PBS-Tween): PBS 1X acrescido de Tween 20 na concentração de $0,05 \%$.

- Solução A: Tris-HCl 25mM, pH 8,0, glicose 50 mM, EDTA 10 mM, pH 8,0.

- Solução B: NaOH 0,2 M, SDS $1 \%$.

- Solução C: acetato de potássio $3 \mathrm{M}$, ácido acético $5 \mathrm{M}$.

- Reativo de Bradford: Coomassie blue G250 0,1\%, etanol $5 \%, \mathrm{H}_{3} \mathrm{PO}_{4} 10 \%$.

- Tampão de amostra para eletroforese de DNA (5X): azul de bromofenol 0,25\%, xileno-cianol $0,25 \%$, glicerol $3 \%$.

- Tampão de amostra para SDS-PAGE (4X): glicerol 20\%, SDS 4\%, 2-Mercaptoetanol (2-ME) 10\%, Tris- $\mathrm{HCl} 60 \mathrm{mM}, \mathrm{pH}$ 6,8, azul de bromofenol 0,03\%.

- Tampão carbonato 0,05 M: $\mathrm{Na}_{2} \mathrm{CO}_{3}$ 0,015 M, $\mathrm{NaHCO}_{3}$ 0,035 M, pH 9,6.

- Solução de revelação do ELISA: $\mathrm{H}_{2} \mathrm{O}$ destilada, tampão fosfato $\mathrm{Na}_{2} \mathrm{HPO}_{4} 0,2 \mathrm{M}$, ácido cítrico 0,2 $\mathrm{M}$ (para acertar o pH, entre 4,5 e 5), OPD $1 \mathrm{mg} / \mathrm{mL}$ (Sigma) e $\mathrm{H}_{2} \mathrm{O}_{2} 30 \% 1 \mu \mathrm{L} / \mathrm{mL}$.

- Solução de parada da reação do ELISA: $\mathrm{H}_{2} \mathrm{SO}_{4} 4 \mathrm{~N}$ (qsp).

- Tampão de transferência (Immunoblotting): glicina $192 \mathrm{mM}$, Trizma base $25 \mathrm{mM}$, metanol $20 \%$.

- Tampão de sonicação (Binding): $\mathrm{NaCl} 300 \mathrm{mM}, \mathrm{NaH}_{2} \mathrm{PO}_{4} 500 \mathrm{mM}$, lisozima $1 \mathrm{mg} / \mathrm{mL}$ e PMSF 100 mM, pH=8,0. 
- Tampão de lavagem (Wash): $\mathrm{NaCl}$ 0,12 M, $\mathrm{NaH}_{2} \mathrm{PO}_{4}$ 0,05 M, glicerol 10\%, pH=8,0.

- Tampão de eluição (elution): $\mathrm{NaCl} 0,12 \mathrm{M}, \mathrm{NaH}_{2} \mathrm{PO}_{4} 0,05 \mathrm{M}$, glicerol 10\%, Imidazol $500 \mathrm{mM}$ e PMSF $100 \mathrm{mM}, \mathrm{pH}=8,0$.

- Solução de revelação do ELISPOT: $\mathrm{H}_{2} \mathrm{O}$ destilada, Tris-HCl 50 mM, DAB 1 mg/mL (Sigma) e $\mathrm{H}_{2} \mathrm{O}_{2} 30 \% 1 \mu \mathrm{L} / \mathrm{mL}$.

\subsection{Meios de cultura}

\subsubsection{Meios para cultura de bactérias}

- LB ( Luria Broth): triptona 1\%, extrato de levedura 0,5\%, $\mathrm{NaCl}$ 0,05\%, pH 7,0.

- LB ágar: LB ágar (Difco) 1,5\%.

- LB-canamicina: LB ágar, canamicina (Sigma) $30 \mu \mathrm{g} / \mathrm{ml}$.

- SOB: triptona $2 \%$, extrato de levedura 0,5\%, $\mathrm{NaCl} 0,05 \%, \mathrm{KCl} 2,5 \mathrm{mM} \mathrm{pH} \mathrm{7,0.}$

- SOC: SOB, $\mathrm{MgCl}_{2} 10 \mathrm{mM}$, glicose $20 \mathrm{mM}$.

3.3 Geração dos genes sintéticos codificando cada uma das regiões variantes e, geração de um gene sintético codificando todas as três regiões variantes de aminoácidos, descritas nas diferentes cepas de $P$. vivax, em fusão

Genes sintéticos com códons otimizados foram produzidos pela GenScript e baseados nas sequências de nucleotídeos descritas abaixo, representando as três diferentes formas da proteína CSP de P. vivax (PvCSP-VK210, PvCSP-VK247 e PvCSP- Vivax-like). Um quarto gene foi produzido contendo a sequência de nucleotídeos codificando os três epítopos imunodominantes das regiões repetidas (PVCSP-All-CS epitopes). Como as regiões $\mathrm{N}$ e $\mathrm{C}$ terminais são conservadas foram mantidas as mesmas sequências primárias para todas.

As regiões sublinhadas e em negrito, nas sequências de nucleotídeos, representam os sítios para NdeI (CATATG) e BamHI (GGATCC). 


\section{PvCSP-VK210}

$5^{\prime}-$

AGCCATATGACCCACTGCGGCCATAACGTTGACCTGTCTAAAGCGATTAACCTGAACGGTGTTAACTTTAACAAC GTTGATGCCTCCTCCCTGGGTGCCGCGCATGTTGGTCAGAGCGCATCCCGCGGTCGTGGCCTGGGCGAAAACCCG GATGACGAAGAAGGCGACGCGAAAAAGAAAAAAGACGGTAAAAAAGCGGAACCGAAAAACCCGCGTGAAAACAAA CTGAAACAGCCGGGCGACCGCGCGGATGGCCAGCCGGCCGGCGACCGTGCGGATGGCCAGCCGGCAGGCGACCGT GCGGATGGTCAGCCGGCCGGTGACCGTGCGGACGGTCAGCCGGCGGGCGACCGCGCTGCAGGCCAGCCGGCCGGT GACCGCGCCGATGGCCAGCCGGCTGGCGACCGCGCGGATGGTCAGCCGGCGGGTGATCGCGCGGACGGTCAGCCG GCAGGTGATCGCGCAGACGGTCAGCCGGCCGGCGATCGCGCGGCAGGCCAGCCGGCGGGCGACCGTGCGGCCGGT CAGCCGGCGGGTGATCGTGCCGACGGCCAGCCGGCGGGTGACCGCGCTGCGGGTCAGCCGGCAGGCGACCGCGCG GACGGCCAGCCGGCAGGTGACCGTGCAGCGGGCCAGCCGGCTGGCGACCGTGCCGATGGTCAGCCGGCCGGCGAT CGTGCGGCAGGCCAGCCGGCTGGTGACCGTGCCGCGGGTCAGCCGGCAGGTGACCGCGCAGCGGGTCAGGCCGCA GGTGATCGTGCGGCGGGTCAGGCCGCGGGCGGTAACGCGGGCGGCCAGGGCCAGAACAACGAAGGCGCAAACGCT CCGAACGAAAAATCCGTGAAAGAATACCTGGATAAAGTGCGTGCGACCGTTGGTACCGAATGGACCCCGTGTTCC GTGACCTGTGGCGTTGGCGTTCGCGTGCGCCGCCGTGTTAACGCAGCGAACAAAAAACCGGAAGATCTGACCCTG AACGATCTGGAAACCGACGTTTGTACCTAACGCGGATCC - 3’

\section{Número de acesso no GenBank: KF971719}

\section{PvCSP-VK247}

$5^{\prime}-$

AGCCATATGACCCACTGCGGCCATAACGTGGATCTGTCTAAAGCGATCAACCTGAACGGTGTGAACTTCAACAAC GTTGACGCATCTAGCCTGGGTGCAGCACACGTTGGCCAGTCCGCATCTCGCGGTCGTGGCCTGGGTGAAAACCCG GATGACGAAGAAGGCGATGCGAAAAAGAAAAAAGACGGTAAAAAAGCCGAACCGAAAAACCCGCGTGAAAACAAA CTGAAACAGCCGGGTGCTAACGGTGCAGGTAACCAGCCGGGTGCAAACGGCGCGGGTAACCAGCCGGGCGCGAAC GGCGCTGGCAACCAGCCGGGCGCAAACGGCGCTGGTAACCAGCCGGGCGCCAACGGCGCCGGCAACCAGCCGGGT GCGAACGGCGCCGGTAACCAGCCGGGCGCTAACGGCGCAGGCAATCAACCGGGCGCGAACGGCGCGGGCAACCAG CCGGGTGCCAACGGCGCAGGCAATCAGCCTGGCGCGAACGGCGCAGGCAACCAGCCGGGTGCTAACGGCGCAGGA AATCAGCCGGGCGCTAACGGTGCGGGCAATCAACCGGGTGCCAACGGTGCGGGCAATCAGCCTGGTGCCAACGGC GCAGGAAACCAACCGGGCGCGAACGGTGCGGGTAATCAACCGGGTGCGAATGGCGCTGGCAATCAACCGGGCGCA AATGGCGCGGGAAATCAGCCGGGTGCAAACGGTGCGGGTAATCAGCCCGGTGCCAACGGCGCAGGGAATCAACCT GGCGCTAACGGCGCAGGTAACCAGCCGGGCGGTAACGCGGGTGGCCAGGGCCAGAACAACGAAGGTGCGAACGCA CCGAACGAAAAAAGCGTGAAAGAATACCTGGATAAAGTGCGCGCGACCGTTGGTACCGAATGGACCCCGTGCTCC GTGACCTGTGGCGTTGGTGTGCGTGTTCGTCGCCGTGTTAACGCTGCCAACAAAAAACCGGAAGACCTGACCCTG AACGATCTGGAAACCGACGTTTGTACCTAACGCGGATCC - 3’

\section{Número de acesso no GenBank: KF971720}

\section{PvCSP-Vivax-like}

\section{$5^{\prime}-$}

AGCCATATGACCCACTGCGGTCATAACGTGGATCTGTCTAAAGCGATCAACCTGAACGGCGTGAACTTCAACAAC GTTGACGCATCTAGCCTGGGTGCAGCACACGTTGGCCAGTCCGCATCTCGTGGTCGTGGTCTGGGTGAAAACCCG GATGACGAAGAAGGCGATGCGAAAAAGAAAAAAGACGGTAAAAAAGCGGAACCGAAAAACCCGCGCGAAAACAAA CTGAAACAGCCGGGTGCACCGGGTGCTAACCAGGAAGGTGGCGCTGCAGCACCGGGTGCAAACCAGGAAGGTGGC GCAGCGGCGCCGGGCGCGAACCAGGAAGGTGGCGCGGCAGCTCCGGGTGCCAACCAGGAAGGTGGCGCCGCGGCA CCGGGTGCGAATCAAGAAGGTGGCGCGGCGGCGCCGGGCGCAAATCAAGAAGGTGGCGCAGCAGCGCCGGGCGCA AATCAGGAAGGTGGCGCAGCTGCGCCGGGCGCTAATCAAGAAGGTGGCGCTGCTGCACCGGGTGCGAATCAGGAA GGTGGCGCCGCTGCGCCGGGCGCAAACCAAGAAGGTGGCGCAGCCGCGCCGGGCGCAAACCAGGAAGGTGGCGCA GCCGCACCTGGCGCGAATCAAGAAGGTGGCGCCGCTGCTCCGGGTGCGAACCAAGAAGGTGGCGCGGCTGCGCCG GGCGCTAACCAAGAAGGTGGCGCTGCGGCGCCGGGCGCTAATCAGGAAGGTGGCGCGGCGGCTCCGGGTGCGAAC CAGGAAGGTGGCGCAGCAGATCGTGCAGCTGGTCAGGCAGCGGGTGGCAACGCGGGTGGCCAGGGCCAGAACAAC GAAGGTGCCAACGCGCCGAACGAAAAAAGCGTGAAAGAATACCTGGACAAAGTGCGCGCGACCGTTGGTACCGAA TGGACCCCGTGCTCCGTGACCTGTGGCGTTGGTGTGCGTGTTCGTCGCCGTGTTAACGCAGCTAACAAAAAACCG GAAGATCTGACCCTGAACGATCTGGAAACCGACGTTTGTACCTAACGCGGATCC - $\mathbf{3}^{\prime}$

\section{Número de acesso no GenBank: KF971721}




\section{PvCSP-All-CS-epitopes}

$$
5^{\prime-}
$$

AGCCATATGCCCACTGCGGCCATAACGTGGATCTGTCTAAAGCGATCAACCTGAACGGTGTGAACTTCAACAAC

GTTGACGCATCTAGCCTGGGTGCAGCACACGTTGGCCAGTCCGCATCTCGTGGTCGTGGTCTGGGTGAAAACCCG GATGACGAAGAAGGCGATGCGAAAAAGAAAAAAGACGGTAAAAAAGCCGAACCGAAAAACCCGCGTGAAAACAAA CTGAAACAGCCGGGTCCGGGTGATCGTGCAGACGGTCAGCCGGCTGGCGACCGCGCAGACGGTCAGCCGGCAGGT GATCGTGCTGCAGGCCAGCCGGCAGGTGACCGTGCGGCAGGCCAGCCGGCTGGTGATCGCGCCGACGGCCAGCCG GCCGGCGACCGTGCGGACGGTCAGCCGGCTGGTGATCGTGCAGACGCACCGGGCGCCAACCAGGAAGGTGGCGCT GCCGCGCCGGGTGCGAACCAGGAAGGTGGCGCAGCTGCACCGGGTGCAAACCAGGAAGGTGGCGCGGCAGCTGCA CCGGGTGCTAACCAGGAAGGTGGCGCCGCAGCTCCGGGTGCCAATCAAGAAGGTGGCGCCGCGGCGCCGGGCGCA AATCAAGAAGGTGGCGCTGCAGCAGCAAACGGTGCAGGTAACCAGCCGGGTGCGAACGGCGCGGGCAACCAGCCG GGTGCTAACGGCGCGGGTAACCAGCCGGGTGCCAACGGCGCTGGCAACCAGCCGGGCGCGAACGGCGCTGGTAAC CAGCCGGGTGATCGTGCTGCGGGTCAGGCAGCAGGTGGCAACGCGGGTGGCCAGGGTCAGAACAACGAAGGTGCT AACGCCCCGAACGAAAAAAGCGTGAAAGAATACCTGGACAAAGTGCGTGCGACCGTTGGTACCGAATGGACCCCG TGCTCCGTGACCTGTGGCGTTGGTGTGCGCGTTCGTCGCCGTGTTAACGCTGCCAACAAAAAACCGGAAGATCTG ACCCTGAACGATCTGGAAACCGACGTTTGTACCTAACGCGGATCC - 3’

\section{Número de acesso no GenBank: KF971722}

\subsection{Geração dos genes sintéticos codificando cada uma das regiões variantes de aminoácidos, descritas nas diferentes cepas de $P$. vivax}

Genes sintéticos com códons otimizados foram produzidos pela GenScript e baseados nas sequências de nucleotídeos descritas abaixo, representando as regiões centrais de cada uma das três diferentes formas da proteína CSP de P. vivax (PvCSP-VK210, PvCSP-VK247 e PvCSPVivax-like). Cada sequência apresenta uma pequena sequência de nucleotídeos que representa a região N-terminal, que é conservada dentre as três diferentes formas da proteína PvCSP.

As regiões sublinhadas e em negrito, nas sequências de nucleotídeos, representam os sítios para BamHI (GGATCC) e EcoRI (GAATTC).

\section{PvCSP-VK210}

$5^{\prime-}$

GGGATCCCCGAAAACAAACTGAAACAACCGGGCGACCGTGCTGATGGTCAACCGGCTGGTGATCGTGCAGATGGCCAACCGGCAGG CGACCGTGCTGATGGTCAGCCGGCAGGTGATCGTGCTGACGGTCAACCGGCAGGTGATCGTGCAGCCGGTCAGCCGGCGGGTGATC GTGCAGATGGTCAGCCGGCCGGCGACCGTGCTGATGGCCAACCGGCCGGCGATCGTGCAGATGGTCAACCGGCCGGTGACCGCGCT GACGGCCAACCGGCGGGCGATCGTGCAGCTGGTCAACCGGCAGGTGACCGCGCCGCCGGCCAACCGGCGGGTGATCGTGCCGACGG CCAGCCGGCCGGCGATCGCGCCGCCGGCCAGCCGGCCGGTGACCGTGCCGATGGTCAACCGGCGGGTGATCGCGCTGCGGGCCAAC CGGCCGGTGACCGTGCGGACGGCCAGCCGGCGGGTGATCGCGCAGCTGGTCAGCCGGCGGGTGACCGTGCGGCGGGTCAACCGGCC GGCGACCGCGCAGCTGGCCAGGCGGCCGGTGATTAAGGGAATTCA - 3’

\section{PvCSP-VK247}

$5^{\prime}-$

GGGATCCCCGAAAACAAACTGAAACAACCGGGTGCTAATGGTGCGGGTAATCAACCGGGTGCTAATGGTGCTGGTAATCAACCGGG TGCGAACGGCGCAGGTAACCAGCCGGGTGCAAACGGTGCAGGTAATCAACCGGGCGCAAACGGCGCTGGTAATCAGCCGGGTGCGA ACGGCGCCGGCAACCAGCCGGGCGCCAATGGTGCCGGCAATCAACCGGGCGCCAACGGCGCCGGTAACCAGCCGGGCGCCAACGGT GCCGGCAATCAGCCGGGCGCCGGTAATCAACCGGGTGCCAATGGTGCAGGTAATCAGCCGGGTGCCAATGGCGCAGGCAATCAACC GGGTGCCAACGGCGCCGGTAATCAGCCGGGCGCCAATGGCGCAGGTAACCAACCGGGCGCCAACGGTGCGGGCAATCAGCCGGGTG CCAACGGTGCCGGTAACCAACCGGGCGCGAACGGCGCCGGCAATCAGCCGGGCGGTAACTAAGGGAATTCA - 3 


\section{PvCSP-Vivax-like}

$5^{\prime}-$

GGGATCCCCGAAAACAAACTGAAACAGCCGGGCGCTCCGGGTGCGAACCAGGAAGGCGGTGCAGCAGCTCCGGGTGCGAATCAAGA AGGCGGTGCCGCAGCACCGGGTGCAAATCAGGAAGGCGGTGCCGCTGCACCGGGTGCAAATCAAGAAGGCGGTGCGGCCGCTCCGG GTGCTAATCAGGAAGGCGGTGCGGCCGCCCCGGGCGCCAATCAAGAAGGCGGTGCTGCAGCACCGGGTGCAAACCAGGAAGGCGGT GCCGCCGCACCGGGTGCTAACCAAGAAGGCGGTGCCGCCGCTCCGGGCGCCAATCAGGAAGGCGGTGCTGCCGCCCCGGGCGCTAA TCAAGAAGGCGGTGCAGCCGCCCCGGGCGCCAACCAGGAAGGCGGTGCGGCTGCCCCGGGCGCTAATCAAGAAGGCGGTGCAGCGG CCCCGGGCGCGAATCAGGAAGGCGGTGCAGCCGCGCCGGGCGCTAACCAGGAAGGCGGTGCTGCGGCCCCGGGCGCGAACCAGGAA GGCGGTGCTGCTGCTCCGGGTGCGAATCAGGAAGGTTAAGGGAATTCA - 3 '

\subsection{Geração de adenovírus recombinante humano Tipo 5 deficiente de replicação e adenovírus de chimpanzé Tipo 68 expressando a proteína CSP de $P$. vivax para sistema de vacinação prime-boost heterólogo}

Foram gerados dois adenovírus recombinantes, expressando as três regiões imunodominantes em fusão da proteína CSP de $P$. vivax em associação com a Dra. H. Ertl do Wistar Institute. Os adenovírus gerados foram: Adenovírus Humano do tipo 5 (AdH5) e Adenovírus de Chimpanzé do tipo 68 (AdCh68). Genes sintéticos com códons otimizados foram produzidos pela GenScript, e baseado nas sequências de nucleotídeos descritas abaixo.

$5^{\prime-}$

TCTAGAGCCGCCACCATGGGAATGCAGGTGCAGATCCAGAGCCTGTTTCTGCTCCTCCTGTGGGTGCCCGGGTCCAGAGGAACCCA CTGCGGCCACAACGTGGACCTGAGCAAGGCCATCAACCTGATGGCGTAATTTCAACAATGTGGATGCTAGCTCCCTGGGAGCTGCT CACGTGGGACAGTCTGCTAGCCGCGGAAGGGGACTGGGAGAGAACCCAGACGATGAGGAGGGCGACGCCAAGAAGAAGAAGATGGA AAAAGGCTGAGCCAAAGAACCCCAGGGAGAATAAGCTGAAGCAGCCCGGACCTGGGGACAGAGCCGATGGCCAGCCCGCCGGAGAC CGGGCTGATGGACAGCCTGCTGGCGACAGGGCTGCGGACAGCCGCTGGGGATAGAGCCGCTGGACAGCCAGCTGGAGACAGAGCTG ATGGACAGCCTGCCGGCGACAGGGCCGATGGACAGCCTGCTGGGGACAGGGCTGATGCTCCAGGCGCTAACCAGGGGGAGGAGCGC TGCCCCTGGAGCCAATCAGGAAGGCGGAGCTGCCGCTCCAGGCGCCAATCAGGAAGGAGGAGCTGCTGCTGCTCCCGGCGCCAATC AGGAGGGCGGAGCCGCTGCCCCTGGCGCCACCAGGAGGGGGCGCTGCCGCTCCAGGCGCTAATCAGGAGGGCGGCGCTGCTGCTGC TAACGGAGCTGGAAATCAGCCAGGGGCCAATGGAGCTGGAAATCAGCCTGGCGCTAACGGAGCTGGGAACAGCCTGGAGCAACGGC GCCGGCAATCAGCCAGGGGCCAACGGGGCTGGCAATCAGCCCGGCGACAGAGCCGCTGGACAGGCTGCTGGAGGAAACGCTGGAGG ACAGGGACAGAACAATGAGGGGGCAACGCTCCCAAGAGAAGTCCGTGAAGGAGTACCTGGATAAGGTGAGGGCTACCGTGGGCACA GAGTGGACCCCTTGCTCTGTGACATGTGGAGTGGGGGTGAGAGTGAGGAGACGGGTGAACGCCCTAATAAGAAGCCGAGGACCTGA CCCTGAACGACCTGGAGACAGATGTGTGTACCTGAGGTACC - $\mathbf{3}^{\prime}$

\section{Número de acesso no GenBank: KF971723}

As regiões sublinhadas e em negrito, nas sequências de nucleotídeos, representam os sítios para XbaI (TCTAGA) e KpnI (GGTACC). O gene foi sub-clonado no plasmídeo pShuttle (Clontech). O cassete para expressão foi liberado pela digestão com I-CeuI and PI-SceI, e em seguida clonado no clone molecular de Adenovírus - AdCh68 ou AdHu5, digeridos com as mesmas enzimas. Vetores recombinantes adenovirais foram cultivados em células HEK293. Detalhes sobre a geração do adenovírus recombinante foram previamente descritos por Zhou e colaboradores (Zhou et al., 2010). 


\subsection{Transformação bacteriana utilizando vetor plasmidial}

Os genes sintéticos fornecidos pela GenScript foram inseridos no "polylinker" do vetor plasmidial de expressão pET-28a (Novagen). Uma vez gerados, os plasmídios recombinantes foram transformados em E. coli cepa BL21-DE3 (Novagen).

Para cada transformação, 10 a 20 ng de cada vetor plasmidial foram adicionados em tubo tipo eppendorf contendo alíquota de $100 \mu \mathrm{L}$ de bactéria E. coli cepas DH5 $\alpha$ (para clonagem bacteriana) ou BL21-DE3 (para expressão protéica) competentes. Após incubação em gelo por 30 minutos, o tubo foi submetido a $42{ }^{\circ} \mathrm{C}$ por 2 minutos e recolocados em gelo de 5 a 10 minutos. Em seguida, a este tubo, foi adicionado $400 \mu \mathrm{L}$ de meio SOC (preparado imediatamente antes do uso). O tubo foi incubado em Shaker a $37{ }^{\circ} \mathrm{C}$ por 60 minutos sob agitação constante de $200 \mathrm{rpm}$. O volume total contido no tubo foi plaqueado em placa LB-ágar contendo canamicina $30 \mu \mathrm{g} / \mathrm{mL}$, e esta foi incubada em estufa bacteriana à $37^{\circ} \mathrm{C}$, overnight, para seleção dos clones resistentes ao antibiótico. Após o crescimento, colônias foram isoladas e submetidas à análise.

\subsection{Análise das colônias bacterianas por lise alcalina (Mini prep - in house)}

Uma colônia de bactéria recombinante foi inoculada em $3 \mathrm{ml}$ de meio LB brothcanamicina $(30 \mu \mathrm{g} / \mathrm{mL})$ e este foi incubado a $37{ }^{\circ} \mathrm{C}$, overnight (14 a 16 horas), sob agitação constante. A cultura bacteriana foi transferida para tubos de microcentrífuga eppendorf e centrifugadas por 2 minutos, a $13.000 \mathrm{rpm}$, a temperatura ambiente, utilizando microcentrífuga Eppendorf 5415 C. Os sobrenadantes foram descartados. Os pellets bacterianos foram ressuspensos em $100 \mu \mathrm{L}$ de Solução A (solução hipotônica: glicose $50 \mathrm{mM}$, Tris-HCl $25 \mathrm{mM}$, EDTA 10 mM, pH 8,0) e homogeneizados utilizando vortex.

Em seguida, foi adicionado $200 \mu \mathrm{L}$ de solução $\mathrm{B}$ (solução de denaturação: $\mathrm{NaOH}$ 0,2M e SDS 1\%), e os tubos foram invertidos suavemente por 2 vezes e incubados à temperatura ambiente por $4 \mathrm{~min}$. Após este período, foi adicionado $200 \mu \mathrm{L}$ de solução $\mathrm{C}$ (solução de neutralização: Kac $3 \mathrm{M}$, ácido acético glacial $5 \mathrm{M}$, água destilada), e os tubos foram invertidos suavemente por 8 vezes e incubados em gelo por um período de $30 \mathrm{~min}$. Após incubação, estes tubos foram centrifugados a $13.000 \mathrm{rpm}$ por $15 \mathrm{~min}$ à temperatura ambiente . Os sobrenadantes foram transferidos para novos tubos contendo $300 \mu \mathrm{L}$ de isopropanol (Merck) e misturados por inversão por 4 vezes. Posteriormente, os tubos foram incubados a $-20^{\circ} \mathrm{C}$ por $2 \mathrm{~h}$ e, após este período, submetidos à centrifugação a $13.000 \mathrm{rpm}$ por $15 \mathrm{~min}$ a $4{ }^{\circ} \mathrm{C}$. Desta vez, os sobrenadantes foram desprezados, e aos precipitados foram acrescentados $500 \mu \mathrm{L}$ de etanol $70 \%$. 
Estes foram submetidos à agitação utilizando vortex até que desgrudassem do fundo dos tubos. Nova centrifugação foi realizada nas mesmas condições anteriores citadas, porém por 5 min. Novamente os sobrenadantes foram desprezados e os precipitados secos a temperatura ambiente por aproximadamente $20 \mathrm{~min}$. Os precipitados foram ressuspendidos em $60 \mu \mathrm{L}$ solução aquosa contendo RNAse A livre de DNAse (60 $\mu \mathrm{g} / \mathrm{mL}$, Sigma) e incubados a $37^{\circ} \mathrm{C}$, em Banho Maria por $2 \mathrm{~h}$ para ação enzimática.

A análise dos plasmídios recombinantes foi feita em gel de agarose $2 \%$ contendo brometo de etídio, e tampão TAE 1X. A intensidade da banda correspondente ao DNA plasmidial foi comparada com a intensidade das bandas de quantidades conhecidas de DNA do fago $\lambda$ digerido com Hind III (Invitrogen).

\subsection{Eletroforese em gel de agarose}

A eletroforese foi feita em uma cuba para eletroforese horizontal (BioRad) utilizando a voltagem de $100 \mathrm{~V}$ durante aproximadamente $40 \mathrm{~min}$.

\subsection{Análise em sistema de expressão bacteriano, utilizando cepa de $E$ coli}

A expressão em sistema bacteriano foi feita como descrito por Cunha e colaboradores em 2001, e Bargieri e colaboradores em 2008 (Bargieri et al., 2008; Cunha et al., 2001). Préinóculos foram feitos em frascos contendo meio LB líquido e Canamicina (30 $\mu \mathrm{g} / \mathrm{mL})$, a partir de uma alíquota de aproximadamente $100 \mathrm{uL}$ proveniente de glicerol estoque armazenado em freezer $-70{ }^{\circ} \mathrm{C}$, e foram incubados sob agitação constante, $200 \mathrm{rpm}$, sob a temperatura de $37^{\circ} \mathrm{C}$, utilizando Shaker. Após aproximadamente 16 h, $20 \mathrm{~mL}$ dos pré-inóculos foram adicionados aos erlenmeyers contendo cerca de $300 \mathrm{~mL}$ de meio LB/Canamicina $(30 \mu \mathrm{g} / \mathrm{mL})$, e em seguida, incubados sob as mesmas condições acima descritas, até que a densidade óptica, no comprimento de onda $600 \mathrm{~nm}$, chegasse ao valor de 0,6. As culturas bacterianas foram induzidas à expressão protéica com isopropyl- $\beta$-D-thiogalactopyranoside $0,1 \mathrm{mM}$ (IPTG, Sigma), por um período de 4 horas.

Após este período as culturas foram centrifugadas utilizando centrífuga Sorvall. Os sobrenadantes foram desprezados e os "pellets" ressupensos num volume total de $100 \mathrm{~mL}$ de tampão de sonicação ( $\mathrm{NaCl} 300$ mM, NaH2PO4 500 mM, lisozima 1 mg/mL e PMSF 100 mM, pH=8,0, Sigma). O material foi então submetido à ultra-sonicação, onde a cultura bacteriana foi lisada sob incubação no gelo, utilizando um ultra sonicador (Sonics and Materials INC Vibra 
Cell VCX 750). Foi aplicado 3 ciclos com intervalos de 1 segundo por um período de 5 minutos cada. O sobrenadante foi obtido após nova centrifugação utilizando centrífuga Sorvall. O sobrenadante foi ressuspendido em Uréia $8 \mathrm{M}$ (Invitrogen), e em seguida fervidos a $100{ }^{\circ} \mathrm{C}$, por 15 minutos.

\subsection{Purificação das proteínas recombinantes geradas}

\subsubsection{Cromatografia de afinidade}

A purificação foi feita por cromatografia de afinidade utilizando $5 \mathrm{~mL}$ de resina de níquel (Ni2+-NTA, Qiagen). As proteínas foram incubadas juntamente a resina de níquel, submetidas à agitação constante, overnight (12 a 16 h), a $4{ }^{\circ} \mathrm{C}$. Após a incubação, a resina foi extensivamente lavada com tampão de lavagem (Wash: $\mathrm{NaCl}$ 0,12 M, NaH2PO4 0,05 M, glicerol 10\%,pH=8,0), num volume de $200 \mathrm{~mL}$, superior ao recomendado pelo fabricante (5 X o volume total da resina), para retirada de possíveis contaminantes e da uréia. Posteriormente, a resina foi lavada com tampão de eluição (tampão de lavagem contendo Imidazol 500 mM e PMSF 100 mM, pH=8,0, Sigma), para a coleta da proteína de interesse. Cinco diferentes frações foram coletadas e para a confirmação da eluição da proteína, foi feito SDS-PAGE 10\% convencional. As amostras obtidas após eluição (com a presença da proteína de interesse confirmada) foram colocadas em uma membrana de diálise e estas foram dialisadas contra Tris- $\mathrm{HCl} 20 \mathrm{mM}, \mathrm{pH}=8,0$, sob agitação constante, a $4{ }^{\circ} \mathrm{C}$, por um período de aproximadamente 16 horas.

\subsubsection{Cromatografia de troca iônica}

A proteína de interesse foi novamente purificada, desta vez utilizando cromatografia de troca iônica, utilizando coluna Resource Q (GE Healthcare), acoplada ao sistema de FPLC (Akta prime, GE Healthcare). Frações contendo as proteínas recombinantes em alto grau de pureza foram agrupadas. Novamente, para a confirmação da eluição da proteína, foi feito SDS-PAGE $10 \%$ convencional. Após confirmação foi determinada a quantificação de cada proteína purificada utilizando curva de BSA em SDS-PAGE 10\%.

O material foi dialisado contra tampão salino (PBS 1X, pH=7,2), sob agitação constante, a $4{ }^{\circ} \mathrm{C}$, por um período de aproximadamente 16 horas. A concentração das proteínas foi determinada por SDS-PAGE $10 \%$ convencional. 


\subsection{Produção de proteínas recombinantes expressas em fusão com a flagelina (FliC) de Salmonella enterica serovar Typhimurium}

Após a transformação de bactérias E.coli cepa BL21-DE3 com cada um dos vetores de expressão pET28a-FliC-PvCS-VK210, pET28a-FliC-PvCS-VK247, pET28a-FliC-PvCS-Vivaxlike foram geradas três proteínas recombinantes em sistema de expressão bacteriano, representando diferentes formas alélicas do P. vivax (Camacho et al., 2011); Camacho, 2012). As proteínas foram gentilmente cedidas pela estudante Ariane G. A. Camacho, da Universidade Federal de São Paulo, Escola Paulista de Medicina. Estas proteínas recombinantes são denominadas His $_{6}$-FliC-PvCS-VK210, His $_{6}$-FliC-PvCS-VK247, His 6 -FliC-PvCS-Vivax-like.

\subsection{Extração de LPS das proteínas recombinantes PvCSP utilizando agarose de polimixina B (Sigma)}

Para a remoção do LPS das proteínas recombinantes PvCSP produzidas em sistema bacteriano e purificadas através de cromatografia de afinidade e troca iônica, a serem utilizadas em nossas formulações vacinais, usamos agarose de polimixina B (Sigma). Em um tubo tipo Falcon, com capacidade para $15 \mathrm{~mL}, 1 \mathrm{~mL}$ de agarose de polimixina $\mathrm{B}$ foi equilibrada com 10 mL de tampão Tris-HCl 20 mM e $\mathrm{NaCl} 400$ mM, pH 8.0, através de 2 ciclos de centrifugação de $2000 \mathrm{rpm}$, por 5 minutos cada, a temperatura ambiente. Após a centrifugação foi descartado cerca de $3 \mathrm{~mL}$ do sobrenadante e o volume restante foi transferido para um tubo de ensaio de vidro $10 \mathrm{~cm}$ X 10mm. Após a decantação da agarose, foi descartado cerca de $2 \mathrm{~mL}$ do sobrenadante, e a esta foi adicionado $1 \mathrm{mg} / \mathrm{mL}$ de proteína recombinante de interesse $(\mathrm{V} / \mathrm{V})$. A agarose com a proteína foi submetida à agitação constante, overnight, a temperatura ambiente. Após este período, a amostra foi decantada e o sobrenadante contendo a proteína de interesse foi separado. Foi realizada a quantificação da proteína de interesse através da análise em gel de poliacrilamida (SDS-Page) 12\%. A agarose foi reequilibrada com o mesmo volume do tampão inicial utilizado para equilibrá-la, e foi lavada com $5 \mathrm{~mL}$ de solução de desoxicolato de sódio a 1\% (Sigma) seguido de $5 \mathrm{~mL}$ de água MilliQ (Millipore). A agarose foi armazenada em etanol $25 \%$ (Synth) a $4{ }^{\circ} \mathrm{C}$. Todas as solução utilizadas foram preparadas livres de endotoxina, e foram filtradas com filtros para seringa $0.20 \mu \mathrm{m}$ (Corning) esterilizados e descartáveis. 


\subsection{Dosagem do LPS utilizando o Kit E-Toxate (Sigma)}

Para a dosagem do LPS presente nas proteínas recombinantes foi utilizado o kit E-toxate (Sigma) de acordo com as recomendações do fabricante. Cada proteína recombinante foi diluída, em tubos de ensaio de vidro $10 \mathrm{~cm}$ X $10 \mathrm{~mm}$ esterilizados, de acordo com tabela especificada no kit, e foram submetidas a solução reagente de trabalho do kit (E-TOXATE Reagent Working Solution - Sigma). Os tubos foram incubados a $37{ }^{\circ} \mathrm{C}$ por $1 \mathrm{~h}$. A presença de LPS foi considerada positiva quando após o período de incubação, ao inverter os tubos com as diluições a aproximadamente $180{ }^{\circ} \mathrm{C}$, as amostras estavam gelatinosas. E quando a amostra foi considerada positiva, foram feitas novas diluições 1:2 até a obtenção de resultado negativo, fluído, comparado aos controles negativos do ensaio. A dosagem do LPS foi calculada em EU/mL, multiplicando-se o inverso da maior diluição positiva pelo menor concentração do padrão de endotoxina positiva (Endotoxin Standard - Sigma).

\subsection{Produção de proteínas recombinantes contendo sequência GST, em sistema bacteriano, utilizando cepa de $\boldsymbol{E}$ coli}

A expressão em sistema bacteriano foi feita como já descrito acima, porém, pré-inóculos foram feitos em frascos contendo meio LB líquido e Ampicilina $(100 \mu \mathrm{g} / \mathrm{mL})$, a partir de uma alíquota de aproximadamente $100 \mathrm{uL}$ proveniente de glicerol estoque armazenado em freezer -70 ${ }^{\circ} \mathrm{C}$, previamente preparada. Foram incubados sob agitação constante, $200 \mathrm{rpm}$, sob a temperatura de $37{ }^{\circ} \mathrm{C}$, utilizando Shaker. Após aproximadamente 16 h, $20 \mathrm{~mL}$ dos pré-inóculos foram adicionados aos erlenmeyers contendo cerca de $500 \mathrm{~mL}$ de meio LB/Ampicilina $(100 \mu \mathrm{g} / \mathrm{mL})$, e em seguida, incubados sob as mesmas condições acima descritas, até que a densidade óptica, no comprimento de onda $600 \mathrm{~nm}$, chegasse ao valor de 0,6. As culturas bacterianas foram induzidas à expressão protéica com isopropyl- $\beta$-D-thiogalactopyranoside $0,1 \mathrm{mM}$ (IPTG, Sigma), por um período de 3 horas.

Após este período as culturas foram centrifugadas utilizando centrífuga Sorvall. Os sobrenadantes foram desprezados e os "pellets" ressupensos num volume total de $25 \mathrm{~mL}$ de tampão PBS/Triton X - 1\%, na presença de lisozima $1 \mathrm{mg} / \mathrm{mL}$ e PMSF $100 \mathrm{mM}$ (Sigma). O material foi então submetido à ultra-sonicação, onde a cultura bacteriana foi lisada sob incubação no gelo, utilizando um ultra sonicador (Sonics and Materials INC Vibra Cell VCX 750). Foi aplicado 3 ciclos com intervalos de 1 segundo por um período de 5 minutos cada. O sobrenadante foi obtido após nova centrifugação utilizando centrífuga Sorvall. 


\subsection{Purificação de proteínas recombinantes contendo sequência GST em agarose de Glutationa}

\subsubsection{Cromatografia de afinidade}

A purificação foi feita por cromatografia de afinidade utilizando aproximadamente $2 \mathrm{~mL}$ de Glutationa-agarose em tubos de $50 \mathrm{ml}$. A agarose foi submetida a dois ciclos de lavagem com PBS $1 \mathrm{X}(\mathrm{pH}=8,0)$, a $1.000 \mathrm{rpm}$ por 2 minutos. As proteínas foram incubadas juntamente com a agarose, e submetidas à agitação constante, 30 minutos, a temperatura ambiente. Após a incubação, cada agarose misturada a respectiva amostra proteica foi submetida à centrifugação de 1500 rpm por 3 minutos. O Flowthrought foi recolhido para posterior análise. Desta vez, cada agarose foi submetida a cinco ciclos de lavagem com $20 \mathrm{~mL}$ de PBS 1X (pH=8,0), a $1.000 \mathrm{rpm}$ por 2 minutos. Posteriormente, cada agarose foi incubada por 30 minutos, sob agitação constante, a temperatura ambiente, com $2 \mathrm{~mL}$ de tampão de eluição (Tris- $\mathrm{HCl} 1 \mathrm{M}, \mathrm{pH}=8,0$, $\mathrm{NaCl} 5 \mathrm{M}$, Glutationa redutora, Sigma), para a coleta da proteína de interesse. Após o período de incubação, cada agarose foi submetida à centrifugação de $3000 \mathrm{rpm}$ por 3 minutos. Esta etapa de eluição com incubação e centrifugação foi repetida mais duas vezes. Três diferentes frações foram coletadas e para a confirmação da eluição das proteínas de interesse, foi feito SDS-PAGE $13 \%$ convencional.

\subsection{Transferência das proteínas para membranas de nitrocelulose e "immunoblotting"}

As proteínas purificadas contendo cauda de Histidina foram analisadas em gel de poliacrilamida $10 \%$, e as proteínas purificadas contendo sequencia GST foram analisadas em gel de poliacrilamida 13\%. Estas foram transferidas eletroforeticamente para membranas de nitrocelulose (BioRad) usando equipamento "Mini Trans-Blot" (BioRad). Para a transferência foi utilizada voltagem de $100 \mathrm{~V}$ por 60 minutos. Ao final da transferência, as membranas de nitrocelulose foram coradas com o corante transiente Ponceau S 0,2\% (Sigma) por 5 minutos. Os géis utilizados para a transferência foram posteriormente corados com Coomassie blue para a certificação de que as proteínas foram transferidas efetivamente. Em seguida, as membranas foram lavadas com água corrente para a retirada excessiva do corante, e estas foram incubadas em uma solução bloqueio preparada com PBS 1X contendo leite desnatado 5\% (Molico) e albumina bovina sérica (BSA) 2\% (Sigma), por 2 horas. Após o bloqueio, as membranas foram incubadas por 1 hora com anticorpo anti-His (anti Histidina) diluído 1:1000 na solução de 
bloqueio, ou anti-GST diluído 1:500 na solução de bloqueio. Após este período, foram feitos 3 ciclos de lavagens de 10 minutos cada com PBS-Tween 0,05\%. Após lavagem, as membranas foram incubadas por 1 hora com anticorpo anti-IgG de camundongo conjugado à peroxidase (Sigma) diluído 1:2000 na solução de bloqueio. As membranas foram lavadas novamente com PBS-Tween 0,05\%, da mesma forma anteriormente citada. A reação foi revelada utilizando-se 3,3-Diaminobenzidina 0,2 mg/mL (DAB, Sigma) e peróxido de hidrogênio (30\%) em PBS 1X.

\subsection{Animais}

Este estudo foi desenvolvido conforme as recomendações fornecidas pelo Guia para Cuidados e Uso de Animais de Laboratório do Conselho Nacional de Experimentação Animal (http://www.cobea.org.br/). Os protocolos foram aprovados pela Comissão de Ética de Experimentação Animal do Comitê de Ética da Universidade Federal de São Paulo (Id \# CEP 0307/09).

Fêmeas de camundongos isogênicos C57BL/6 (H-2b) de aproximadamente 6 a 8 semanas de idade, mantidos em condições livre de patógenos específicos (SPF - specific pathogen free) foram adquiridas do Centro de Desenvolvimento de Modelos Experimentais para Medicina e Biologia (CEDEME) da Universidade Federal de São Paulo (UNIFESP).

Fêmeas de camundongos deficientes (knock-out) para os receptores tipo Toll 4 (TLR4 ${ }^{-/}$background C57BL/6) de aproximadamente 6 a 8 semanas de idade, mantidos em condições livre de patógenos específicos (SPF - specific pathogen free) foram gentilmente cedidas pelo Dr. Shizuo Akira da Osaka University, Japão. Os experimentos foram aprovados pelo Comitê de Ética em Pesquisa da Universidade Federal de São Paulo e Hospital São Paulo (CEP 0307/09).

\subsubsection{Imunização de camundongos com as proteínas recombinantes geradas na presença de diferentes formulações adjuvantes}

Para a caracterização das propriedades imunogênicas das proteínas recombinantes geradas, os camundongos foram imunizados, num sistema de prime-boost homólogo, com formulações vacinais contendo as proteínas recombinantes geradas mais o adjuvante Completo de Freund (CFA, Sigma), na primeira dose, e Incompleto de Freund (IFA, Sigma) nas doses subsequentes para induzir altos títulos de anticorpos. Camundongos também foram vacinados com formulações vacinais contendo as proteínas recombinantes gerada mais o adjuvante 
Poly(I:C)-HMW (Invivogen), que pode ser utilizado em formulações vacinais para humanos, esperando obter resposta imunológica parecida com CFA/IFA.

Foram feitas formulações vacinais com $10 \mu \mathrm{g}$ de cada proteína individual, ou $10 \mu \mathrm{g}$ de cada proteína em solução (finalizando $30 \mu \mathrm{g}$ totais de proteínas), ou $30 \mu \mathrm{g}$ da proteína contendo as três variações fusionadas geneticamente, na presença dos diferentes adjuvantes: Completo e Incompleto de Freund (v/v) e PBS 1X; Poly(I:C) (50 $\mu \mathrm{g} /$ camundongo) e PBS 1X.

Foram feitas formulações vacinais com $3 \mu \mathrm{g}$ da combinação das 3 proteínas na presença do adjuvante Poly(I:C).

Os adjuvantes CFA/IFA foram emulsificados imediatamente antes da preparação da formulação vacinal, com auxílio de uma seringa de vidro tuberculina (BD).

Os camundongos foram então divididos em 6 grupos, sendo cada grupo com 5 animais. Estes foram imunizados três vezes com intervalo de 3 semanas, onde a primeira dose (dia 0) foi aplicada por via subcutânea (s.c.) nas duas patas traseiras, sendo $50 \mu \mathrm{L}$ em cada uma, e a segunda (dia 21) e terceira (dia 42) doses, onde os animais receberam um reforço, foram aplicadas pela mesma via, porém na base da cauda, com um volume final de $100 \mu \mathrm{L}$.

\subsection{Produção e purificação dos vetores adenovirais recombinantes}

Três vetores adenovirais foram utilizados neste estudo: i) Ad $\beta$-gal; ii) AdHu5-PvCSP e iii) AdCh68-PvCSP.

\subsubsection{Produção de estoque viral}

Para a produção dos adenovírus recombinantes foram preparadas catorze garrafas de cultivo $\left(150 \mathrm{~cm}^{2}\right)$ com células embrionárias de rim humano, HEK293a, com confluência $\geq 90 \%$. Foi estimado que cada garrafa que apresenta monocamada confluente destas células tenha em torno de $10^{7}$ células. As células foram infectadas com amostras purificadas e tituladas de vírus com multiplicidade de infecção de 1 a 10 (m.o.i. 1 a 10), sendo necessárias de $10^{7}$ a $10^{8}$ p.f.u/garrafa. Amostras de vírus foram adicionadas em DMEM a 5\%. As garrafas fechadas foram incubadas a $37^{\circ} \mathrm{C}$, por uma hora. Após o período de incubação, o conteúdo de cada garrafa foi avolumado para $35 \mathrm{~mL}$ com DMEM a 5\%, recém preparado, desta vez, as garrafas semi-abertas foram incubadas a $37{ }^{\circ} \mathrm{C}$ até o desenvolvimento do efeito citopático e desprendimento total das células, cerca de 48 h. O conteúdo das garrafas foi coletado em tubos com capacidade para 50 $\mathrm{mL}$ e centrifugado a $1200 \mathrm{rpm}$ a $4{ }^{\circ} \mathrm{C}$, por $10 \mathrm{~min}$. Os sobrenadantes foram descartados e os 


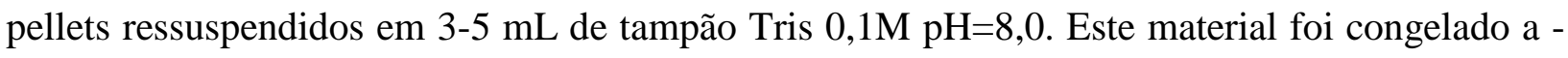
$70{ }^{\circ} \mathrm{C}$.

\subsubsection{Purificação dos vetores adenovirais recombinantes em gradiente de cloreto de césio}

A suspensão de células foi descongelada e misturada a uma solução de deoxicolato sódico 5\%. O volume de deoxicolato usado correspondeu a 1/10 do volume de suspensão de células. A suspensão foi homogenizada e incubada em gelo por $30 \mathrm{~min}$. Para a lise das células, o material foi macerado com ajuda de um potter de vidro até que a consistência da suspensão ficasse líquida, e esta foi avolumada para $16,4 \mathrm{ml}$ com Tris 0,1M pH=8 (este volume correspondeu a $63 \%$ da solução de cloreto de césio). A este volume foi adicionado 9,6 ml de solução saturada de cloreto de césio (este volume correspondeu a 37\% de solução de cloreto de césio). Após homogeneização com vórtex, a amostra foi transferida para tubos de ultracentrífuga (PA, Ultracrimp 11,5ml). Os tubos foram centrifugados a $35.000 \mathrm{rpm}$ a $4{ }^{\circ} \mathrm{C}$ durante $16 \mathrm{~h}$ (Rotor VTI65.1). A banda de adenovírus foi coletada, em fluxo laminar, e dialisada contra Tris 0,01 M $\mathrm{pH}=8$, a $4{ }^{\circ} \mathrm{C}$, por $4 \mathrm{~h}$, sob agitação constante utilizando um agitador magnético. Foram adicionados $10 \%$ glicerol esterilizado ao volume dialisado $(4400 \mu \mathrm{L}+484 \mu \mathrm{L}$ de glicerol autoclavado puro), e este foi aliquotado $(50-100 \mu \mathrm{l})$ e congelado a $-70{ }^{\circ} \mathrm{C}$.

\subsubsection{Titulação de estoques de adenovírus recombinantes}

Em placas de titulação, que consistem em placas de cultivo de 24 poços, foram semeadas células embrionárias de rim humano, HEK293a, numa densidade de 3 x $10^{5}$ células por poço, em DMEM a $5 \%$, e cultivadas durante $24 \mathrm{~h}$ a $37^{\circ} \mathrm{C}$ em estufa com tratamento de $5 \%$ de $\mathrm{CO}_{2}$, até que os poços atingissem confluência $\geq 90 \%$. Paralelamente, foi descongelada uma alíquota de vírus purificado em banho de gelo, sonicada durante 20 segundos em um sonicador de banho (ultrassom), e foi preparada uma diluição inicial de 1:100 $\left(10^{-2}\right)$ do estoque de vírus em DMEM a 5\% (10 uL de vírus purificado + 990 uL de DMEM a 5\%). A partir dessa diluição inicial, foram preparadas diluições em série, com fator 10. As diluições foram preparadas em quadruplicata, da seguinte forma: em uma placa de cultivo de 96 poços, foram adicionados $225 \mathrm{uL}$ de DMEM nas quatro primeiras fileiras completas (linha $\mathrm{A}$ até $\mathrm{D}$, colunas 01 até 12 , completas), com pipetador multicanal foram pipetadas 4 alíquotas de $25 \mathrm{uL}$ da diluição inicial $10^{-2}$ e foram acrescentados à primeira coluna da placa de 96 poços. A operação foi repetida até completar as doze colunas. 
Dessa forma, as diluições feitas na placa de 96 poços foram de $10^{-3}$ (coluna 01) até $10^{-14}$ (coluna 12). Foram usados $200 \mathrm{uL}$ de cada réplica das diluições $10^{-6}$ a $10^{-11}$ para infectar cada poço de cada uma das placas de titulação inicialmente preparadas. As placas foram incubadas por uma hora a $37{ }^{\circ} \mathrm{C}$ em estufa com tratamento de $5 \%$ de $\mathrm{CO}_{2}$. Após a incubação foram adicionados 1500 uL de meio DMEM a 5\% a cada poço de cada uma das placas de titulação. As placas foram incubadas por 7 dias a $37{ }^{\circ} \mathrm{C}$ em estufa com tratamento de $5 \%$ de $\mathrm{CO}_{2}$. O título viral foi calculado a partir da maior diluição de vírus que levou a formação das placas de lise.

\subsubsection{Caracterização da expressão do produto transgênico por imunofluorescência após a infecção in vitro de células HEK293a}

Células embrionárias de rim humano, HEK293a, foram infectadas com os adenovírus recombinantes Adßgal, AdCh68-PvCSP e AdHu5-PvCSP (moi 5 - 5 x $10^{5}$ vp/ml) por 36 horas, em placas de 24 poços. Após o período de incubação, as células foram lavadas por 3 vezes com PBS $1 \mathrm{X}$ e fixadas com paraformaldeído a 4\%, por 30 minutos, a temperatura ambiente. Posteriormente, foram lavadas por 3 vezes com PBS $1 \mathrm{X}$, tratadas por 15 minutos com $50 \mathrm{mM}$ de Cloreto de amônio $\left(\mathrm{NH}_{4} \mathrm{Cl}\right)$. Mais uma vez foram lavadas por 3 vezes com PBS $1 \mathrm{X}$. Na sequência, tratadas com PBS-Triton X-100 a 0,2\% por 30 minutos, a temperatura ambiente. Novamente, foram lavadas com PBS 1X e bloqueadas com tampão fosfato contendo $3 \%$ de albumina sérica bovina (PBS $1 \mathrm{X}+\mathrm{BSA} 3 \%$ ) por 60 minutos a temperatura ambiente. Lamínulas redondas, inicialmente esterilizadas, e presentes nas placas de 24 poços com cultura de células infectadas foram incubadas, ao abrigo da luz, cobertas com soro de camundongos imunizados com as proteínas His ${ }_{6}$-PvCSP-VK210, His ${ }_{6}$-PvCSP-VK247 e His 6 -PvCSP-Vivax-like na presença de Poly(I:C) (1:100), por 1 hora a temperatura ambiente, sob agitação. As lamínulas foram então lavadas por 3 vezes com PBS 1X, e posteriormente, foram incubadas com anticorpo anti-IgG de camundongo conjugado a FITC (1:100) na presença de DAPI (1:500) diluídos em PBS $1 \mathrm{X}+\mathrm{BSA} 3 \%$, por 1h, a temperatura ambiente, ao abrigo da luz, sob agitação. As lamínulas foram então lavadas por 3 vezes, em PBS 1X contendo glicina $50 \mathrm{mM}$, levemente secas e montadas em lâminas com uma gota de tampão glicerina mais PPD (derivado do DAB), seladas com esmalte. Em seguida, foram analisadas em microscópio óptico de fluorescência com aumento de $100 \mathrm{X}$. 


\subsubsection{Imunização de camundongos com os adenovirus recombinantes gerados na presença ou na ausência da formulação adjuvante Poly $(I: C)$}

Para a caracterização das propriedades imunogênicas dos adenovírus recombinantes gerados, os camundongos foram imunizados, em sistemas de prime-boost homólogo e heterólogo, com formulações vacinais contendo adenovírus $\beta$-galactosidase, como controle negativo do experimento, ou AdCh68-PvCSP, ou a mistura das proteínas recombinantes PvCSP geradas, na presença ou na ausência do adjuvante Poly(I:C)-HMW (Invivogen), que pode ser utilizado em formulações vacinais para humanos.

Camundongos foram divididos em 3 grupos, sendo cada grupo com 5 animais. Foram imunizados três vezes, com intervalos de 21 dias, pela via intramuscular (i.m.) no Tibialis anterioris, quando administradas formulações vacinais contendo adenovírus recombinantes, na dose inicial (dia 0) de $2 \times 10^{8}$ pfu, sendo 50 uL da solução em cada músculo. Camundongos que foram imunizados com a mistura das proteínas recombinantes PvCSP, na presença Poly(I:C), receberam doses vacinais, pela via subcutânea (s.c.), de $50 \mathrm{uL}$ em cada pata traseira, na dose inicial (dia 0), e $100 \mathrm{uL}$ na base da cauda nas duas doses subsequentes (dias 21 e 42). Os ensaios imunológicos de resposta celular foram realizados 2 semanas após a última dose.

\subsection{Resposta imune humoral contra as regiões variantes da CSP de $P$. vivax}

\subsubsection{Ensaios Imunoenzimáticos (ELISA) para detecção de anticorpos do tipo IgG total utilizando soros de camundongos imunizados}

A detecção de anticorpos IgG anti-His ${ }_{6}$-PvCSP-VK210, His 6 -PvCSP-VK247 e His $6^{-}$ PvCSP-Vivax-like foi determinada através de ELISA (Enzyme-Linked Immunoabsorbent Assay), utilizando soros de camundongos que receberam vacinas contendo as proteínas recombinantes geradas individualmente, contendo simultaneamente as três proteínas recombinantes e soros daqueles que receberam somente uma proteína contendo as três regiões em fusão.

Amostras de sangue dos animais foram coletadas pela veia da cauda a cada 3 semanas. A primeira sangria foi feita após a $2^{\mathrm{a}}$ dose vacinal (dia 43). A segunda, 3 semanas após a $3^{\mathrm{a}}$ dose vacinal (dia 64). A terceira, 6 semanas após a $3^{\text {a }}$ dose vacinal (dia 83). A quarta, 4 meses após a $1^{\text {a }}$ dose vacinal (dia 121) e a quinta, 6 meses após a $1^{\text {a }}$ dose vacinal (dia 181). O sangue foi centrifugado, a $1.000 \mathrm{rcf}$ por 10 minutos à temperatura ambiente. $\mathrm{O}$ soro foi separado em tubos 
previamente identificados, e estocado a $-20{ }^{\circ} \mathrm{C}$ (freezer) para análise posterior. A longevidade da resposta imune foi acompanhada por até 6 meses.

Os ensaios de ELISA foram feitos em microplacas de poliestireno de 96 poços (“Covalent binding surface", Costar) sensibilizadas com as próprias proteínas recombinantes, His $_{6}$-PvCSP-VK210, His 6 -PvCSP-VK247 e His ${ }_{6}$-PvCSP-Vivax-like, ou GST-PvCSP-VK210, GST-PvCSP-VK247 e GST-PvCSP-Vivax-like, na concentração de 2 ng/uL, ajustada para todas as proteínas com curva de calibração anti-His ${ }_{6}$ (anti cauda de Histidina), ou anti GST, ou através do uso dos monoclonais MAb2F2 (anti-VK210) ou MAb 2E10.E9 (anti-VK247), ou ainda do policlonal anti-Flic Vivax-like (pois este é específico para a repetição dos aminoácidos desta variante da PvCSP), em solução tampão carbonato 0,05 M. As microplacas foram mantidas a temperatura ambiente overnight (14 a 16 h). Estas foram então lavadas 3 vezes com PBS 1X Tween 0,05\% (200 $\mu \mathrm{L} /$ poço) e foram bloqueadas com solução bloqueio ( $5 \%$ de leite desnatado [Molico] e 2\% de BSA [Sigma] em PBS $1 \mathrm{X} \mathrm{pH} \mathrm{7,2)} \mathrm{por} 2 \mathrm{~h}$ à $37^{\circ} \mathrm{C}$. Após este período foi adicionado anticorpo primário diluído em solução bloqueio. Foi utilizado como anticorpo primário o soro dos camundongos imunizados com as proteínas recombinantes. Cada soro foi analisado em diluições seriadas (de 1:200 até 1:6.553.600). Títulos de anticorpos específicos anti-PvCSP foram determinados como a menor diluição entre 0,1 e 0,2 na D.O. $492 \mathrm{~nm}$. As placas foram incubadas por mais $1 \mathrm{~h}$ à $37^{\circ} \mathrm{C}$. As microplacas foram lavadas 5 vezes com PBS $1 \mathrm{X}$ Tween 0,05\% (200 $\mu \mathrm{L} /$ poço) e em seguida, foi adicionado anticorpo secundário murino antiporção Fc da IgG conjugado à peroxidase (Sigma), na diluição de 1:1000. As microplacas foram incubadas por mais $1 \mathrm{~h}$ à $37^{\circ} \mathrm{C}$. Novamente, estas foram lavadas 5 vezes com PBS $1 \mathrm{X}$ Tween 0,05\% (200 $\mu \mathrm{L} /$ poço) e a atividade enzimática foi detectada através de solução de revelação (100 $\mu \mathrm{L} /$ poço) contendo água destilada, tampão fosfato $\mathrm{Na}_{2} \mathrm{HPO}_{4}$ 0,2 M, ácido cítrico 0,2 M, OPD $1 \mathrm{mg} / \mathrm{mL}$ (Sigma) e $\mathrm{H}_{2} \mathrm{O}_{2} 30 \% 1 \mu \mathrm{L} / \mathrm{mL}$, durante $15 \mathrm{~min}$. A reação foi neutralizada pela adição de $\mathrm{H} 2 \mathrm{SO} 44 \mathrm{~N}(50 \mu \mathrm{L} /$ poço) e as leituras foram realizadas a $492 \mathrm{~nm}$ em leitor de microplaca de Elisa (Spectramax).

\subsubsection{ELISA - subclasses de IgG}

A detecção de anticorpos específicos das subclasses de IgG anti-His ${ }_{6}$-PvCSP-VK210, His $_{6}$-PvCSP-VK247 e His 6 -PvCSP-Vivax-like foi determinada através de ELISA (EnzymeLinked Immunoabsorbent Assay), utilizando soros de camundongos que receberam vacinas contendo simultaneamente as três proteínas recombinantes e soros daqueles que receberam 
somente uma proteína contendo as três regiões em fusão na presença dos adjuvantes CFA/IFA e Poly(I:C).

O ensaio foi realizado exatamente como descrito acima, porém foram adicionados anticorpos secundários murinos anti-porção $\mathrm{Fc}$ das subclasses de $\operatorname{IgG}, \operatorname{IgG} 1, \operatorname{IgG} 2 \mathrm{~b}$ e $\operatorname{IgG} 2 \mathrm{c}$ conjugados à peroxidase (Sigma), na diluição de 1:2000. Cada soro foi analisado em diluições seriadas (de 1:200 até 1:6.553.600). Títulos de anticorpos específicos foram determinados como a menor diluição entre 0,1 e 0,2 na D.O. $492 \mathrm{~nm}$.

Foi determinada a razão dos títulos de anticorpos obtidos entre IgG1 e IgG2c.

\subsubsection{Imunofluorescência utilizando soros de camundongos imunizados com as proteínas recombinantes geradas na presença do adjuvante Poly(I:C)}

Soros de animais imunizados simultaneamente com as três proteínas produzidas individualmente mais o adjuvante, $\mathrm{His}_{6} \mathrm{PvCSP}_{\mathrm{N}} \mathrm{VK} 210+\mathrm{His}_{6} \mathrm{PvCSP}_{\mathrm{V}} \mathrm{VK} 247+\mathrm{His}_{6} \mathrm{PvCSP}-$ Vivax-like + Poly(I:C), ou com a proteína híbrida contendo os três epítopos geneticamente fusionados mais o adjuvante, $\mathrm{His}_{6} \mathrm{PvCSP}$-All-CS-epitopes + Poly(I:C), foram selecionados para o ensaio de imunofluorescência, com a finalidade de demonstrar a especificidade dos anticorpos que foram gerados nestes camundongos.

Lâminas contendo esporozoítas de $P$. vivax fixados em ar, gentilmente doadas pelo Dr. Stephen Hoffman da Sanaria Inc., ou pelo Dr. Sócrates Herrera (Malaria Vaccine and Drug Develpment Center, Cali, Colombia) foram bloqueadas com tampão fosfato contendo $3 \%$ de albumina sérica bovina (PBS $1 \mathrm{X}+\mathrm{BSA} 3 \%$ ) por 30 minutos a temperatura ambiente. Em seguida as lâminas foram incubadas em câmara úmida por $1 \mathrm{~h}$ a temperatura ambiente com anticorpo monoclonal 2F2 (anti-PvCSP-VK210) $1 \mu \mathrm{g} / \mathrm{mL}$ como controle positivo ou com soro de camundongos foram imunizados apenas com adjuvante, diluído 1:1.000, como controle negativo. Adicionalmente, foram utilizados soros de animais previamente imunizados com a misturas das três proteínas $\left(\mathrm{His}_{6} \mathrm{PvCSP}-\mathrm{VK} 210+\mathrm{His}_{6} \mathrm{PvCSP}-\mathrm{VK} 247+\mathrm{His}_{6} \mathrm{PvCSP}-\mathrm{Pivax}-\right.$ like $)$ mais Poly(I:C) diluídos 1:1.000, 1:10.000 ou 1:100.000, ou soro de animais imunizados com o protocolo de imunização e reforço heterólogo, diluído 1:100, 1:1.000, 1:10.000 ou 1:100.000. As diluições foram realizadas em PBS 1X + BSA 3\% e testadas em duplicata. Após imersão em PBS 1X para lavagem das lâminas, estas foram incubadas por $1 \mathrm{~h}$ a temperatura ambiente com PBS 1X + BSA 3\% contendo anticorpos caprinos conjugados com FITC, reativos contra IgG murina (Kirkegaard \& Perry Laoratories, Inc), na concentração de 0,02 mg/mL. As lâminas foram então lavadas em PBS 1X contendo glicina $50 \mathrm{mM}$, levemente secas e montadas com 
glicerol tamponado. Em seguida, foram analisadas em microscópio óptico de fluorescência com aumento de $100 \mathrm{X}$.

\subsection{Resposta imune celular estimulada com CSP de $P$. vivax. Medição da resposta imune mediada por linfócitos $\mathrm{T} \mathrm{CD4}^{+}$e $\mathrm{T} \mathrm{CD8}^{+}$}

\subsubsection{Peptídeos sintéticos}

Peptídeos sintéticos foram obtidos da Genscript (Piscataway, NJ). A lista de peptídeos usados se encontra nos Resultados. A pureza destes peptídeos variou de 75,7 \% a 97,5 \%.

\subsubsection{ELISPOT}

Para o ensaio de ELISPOT, foram utilizadas placas de nitrocelulose de 96 poços (Multiscreen HA, Milipore) cobertas com $60 \mu \mathrm{l} /$ poço de PBS estéril contendo $10 \mu \mathrm{g} / \mathrm{mL}$ do anticorpo monoclonal anti-IFN- $\gamma$ de camundongo (R4-6A2, Pharmingen). Após incubação overnight, a temperatura ambiente, a solução contendo o anticorpo monoclonal foi removida por aspiração em capela de fluxo laminar e as placas foram lavadas por 3 vezes com RPMI. As placas foram bloqueadas através da adição de $100 \mu \mathrm{L}$ por poço de meio RPMI contendo $10 \%$ de soro fetal bovino por, pelo menos, $2 \mathrm{~h}$ a $37^{\circ} \mathrm{C}$ em estufa com tratamento de $\mathrm{CO}_{2}$.

As células respondedoras foram obtidas através da maceração individual do baço de camundongos imunizados com adenovírus recombinantes expressando ou não a proteína PvCSPAll-CS-epitopes, ou com a mistura das proteínas recombinantes PvCSP na presença do adjuvante Poly(I:C). Estas células foram lavadas 3 vezes com meio RPMI e então ressuspendidas em meio RPMI completo na concentração de $1 \times 10^{6}$ células viáveis $/ \mathrm{ml}$. O meio completo foi formulado com: $1 \%$ de NEAS, L-glutamina, vitaminas e piruvato, $5 \times 10^{-5} \mathrm{M} 2-\mathrm{ME}, 10 \%$ de soro fetal bovino (Hyclone) e $30 \mathrm{U} / \mathrm{mL}$ de interleucina-2 humana recombinante (cedida por Hoffman-La Roche).

As culturas de esplenócitos foram estimuladas com 29 peptídeos sintéticos (todos obtidos da GeneScript, USA) representantes da proteína PvCSP inteira, ou seja, N e C-terminais, e as três variantes da região central da proteína PvCSP, individualmente ou misturados. A concentração final de cada peptídeo em cultura foi de $10 \mu \mathrm{g} / \mathrm{mL}$. Ou, culturas de esplenócitos foram estimuladas com diferentes proteínas recombinantes PvCSP. 
As placas contendo as culturas foram incubadas por $48 \mathrm{~h}$ a $37{ }^{\circ} \mathrm{C}$ em estufa com tratamento de $5 \%$ de $\mathrm{CO}_{2}$. Após incubação, as células foram desprezadas. Para a remoção de quaisquer células residuais, as placas foram lavadas por 3 vezes com PBS $1 \mathrm{X}$ e 5 vezes com PBS-Tween 20 a 0,05 \%. Cada poço recebeu então $75 \mu \mathrm{L}$ do anticorpo monoclonal anti-IFN- $\gamma$ de camundongo biotinilado XMG1.2 (Pharmingen) diluído em PBS-Tween 20 a 0,05\%, na diluição final de 1:200. As placas foram embrulhadas em papel alumínio para o abrigo da luz e foram incubadas a $4{ }^{\circ} \mathrm{C}$, overnight (aproximadamente $16 \mathrm{~h}$ ). As placas foram lavadas 6 vezes com PBSTween 20 a 0,05\% para a remoção dos anticorpos não ligados. Após a lavagem, foram adicionados $100 \mu \mathrm{L}$ /poço de estreptoavidina-peroxidase (KPL) na proporção de 1:500 diluída em PBS-Tween 20 a $0,05 \%$. As placas foram incubadas por $2 \mathrm{~h}$ a temperatura ambiente e, lavadas 5 vezes com PBS-Tween 20 a 0,05\% e mais 3 vezes com PBS 1X. O ensaio foi revelado com a adição de $100 \mu \mathrm{L} /$ poço do substrato da peroxidase $(50 \mathrm{mM}$ Tris- $\mathrm{HCl}, \mathrm{pH} 7.5$, contendo $1 \mathrm{mg} / \mathrm{ml}$ de $\mathrm{DAB}$ e $1 \mu \mathrm{L} / \mathrm{mL}$ de $30 \%$ de peróxido de hidrogênio, ambos da SIGMA). Depois da incubação de 15 min a temperatura ambiente, a reação foi interrompida através do descarte da solução substrato e da lavagem das placas com água corrente. As placas foram secas a temperatura ambiente e o número de células produtoras de IFN- $\gamma$ (CFS - células formadoras de SPOTS) foram estimadas com o auxílio de uma lupa.

\subsubsection{Isolamento de linfócitos, coloração na superfície celular e coloração intra-celular (ICS)}

As células respondedoras foram obtidas através da maceração individual do baço de camundongos imunizados com adenovírus recombinantes expressando ou não a proteína PvCSPAll-CS-epitopes, ou com a mistura das proteínas recombinantes PvCSP na presença do adjuvante Poly(I:C). Os eritrócitos foram lisados usando tampão hemolítico, ACK, $\left(0.15 \mathrm{M} \mathrm{NH}_{4} \mathrm{Cl}, 1 \mathrm{mM}\right.$ $\mathrm{KHCO}_{3}, 0.1 \mathrm{mM}$ EDTA, pH 7.2-7.3). Após duas lavagens com RPMI, os esplenócitos foram ressuspendidos em meio R10 \% (RPMI 1640 com 10\% de soro fetal bovino). A viabilidade das células foi determinada utilizando o corante Azul de Tripan (0.2\%). A concentração das células foi estimada em câmara de Neubaue, em $5 \times 10^{6}$ células/mL. A estas culturas de esplenócitos foram adicionados $2 \mathrm{ug} / \mathrm{mL}$ de anticorpo anti-CD28, $5 \mathrm{ug} / \mathrm{mL}$ de monensina (BD Biosciences) e $10 \mathrm{ug} / \mathrm{mL}$ de brefeldina A (BD Biosciences). As células em cultura foram estimuladas com os

peptídeos e com as proteínas PvCSP, anteriormente citadas, na concentração de $10 \mathrm{ug} / \mathrm{mL}$, ou com Concanavalina A (ConA, Sigma), na concentração de $2 \mathrm{ug} / \mathrm{mL}$. As células foram cultivadas em triplicatas, em placas de microtitulação de 96 poços, com fundo V (Corning), num volume final de $200 \mathrm{uL}$ por poço. Após $12 \mathrm{~h}$ de incubação, a $37{ }^{\circ} \mathrm{C}$ em estufa com tratamento de $5 \%$ de 
$\mathrm{CO}_{2}$, a placa foi centrifugada a $1700 \mathrm{rpm}$, por 5 minutos, a $4{ }^{\circ} \mathrm{C}$. O sobrenadante foi desprezado e a placa lavada com tampão MAC`s (0,5 \% BSA, 2 mM EDTA, PBS 1X) e mais uma vez centrifugada a $1700 \mathrm{rpm}$, por 5 minutos, a $4{ }^{\circ} \mathrm{C}$. O sobrenadante foi desprezado e foi adicionado anti-CD16/CD32 (1:100) (Fc block- BD Biosciences). Após 15 minutos de incubação a $4{ }^{\circ} \mathrm{C}$, a placa foi lavada com tampão MAC`s, e mais uma vez centrifugada a $1700 \mathrm{rpm}$, por 5 minutos, a $4{ }^{\circ} \mathrm{C}$. As células foram marcadas com um mix de anticorpos para superfície (1:100) com antiCD8 marcado com PECy7 (clone 53-6.7) e anti- CD4 marcado com PerCp Cy5.5 (clone RM45). A placa foi incubada por 20 minutos, a $4{ }^{\circ} \mathrm{C}$. A placa foi lavada 2 vezes com tampão MAC`s, e mais uma vez centrifugada a $1700 \mathrm{rpm}$, por 5 minutos, a $4{ }^{\circ} \mathrm{C}$. Após este período, a placa foi passada no vortex até desfazer os pellets. Foi adicionado $100 \mathrm{uL} /$ poço de tampão de fixação e permeabilização (Cytofix/Cytoperm - BD Biosciences) e a placa foi incubada por $20 \mathrm{~min}$, a $4{ }^{\circ} \mathrm{C}$. Após este período, foi adicionado $100 \mathrm{uL}$ /poço de tampão Perm/Wash (BD Biosciences), para a lavagem da placa, e mais uma vez centrifugada a $1700 \mathrm{rpm}$, por 5 minutos, a $4{ }^{\circ} \mathrm{C}$, por 2 vezes. $\mathrm{O}$ sobrenadante foi desprezado e foi adicionado um mix de anticorpos para marcação intracelular (1:100) com anti-IL-2 marcado com FITC (JES6-5H4), anti-IFN- $\gamma$ marcado com APC (Clone XMG1.2) e anti-TNF- $\alpha$ marcado com PE (Clone MP6-XT 22). A placa foi incubada por 20 minutos, a $4{ }^{\circ} \mathrm{C}$. Após incubação, foi adicionado $100 \mathrm{uL} /$ poço de tampão MAC`s, as células marcadas foram homogeneizadas, e distribuídas em tubos para a leitura no citômetro (Cluster tubes - Corning) e foram fixadas com $100 \mathrm{uL}(\mathrm{V} / \mathrm{V})$ de paraformaldeído a 1\%. A fluorescência celular foi medida através do FACS Canto II (BD - Biosciences) com aquisição de $10^{6}$ células (eventos), e os dados foram analisados através do software FlowJo (Tree Star, Ashland, OR).

\subsection{Análises estatísticas}

Os resultados obtidos foram apresentados como média \pm desvio padrão e analisados pelo teste paramétrico de análise de variância One-way Anova. As diferenças entre os grupos de camundongos imunizados foram determinadas através do Tukey HSD test, disponíveis no site http://faculty.vassar.edu/lowry/VassarStats.htm. 
4 RESULTADOS 


\subsection{Desenho dos genes sintéticos para expressão de proteínas recombinantes representando} as diferentes variantes da CSP de Plasmodium vivax (PvCSP) em bactérias E. coli

O intuito inicial do nosso trabalho foi o de gerar quatro proteínas recombinantes baseadas nas sequiencias primárias deduzidas da CSP das diferentes cepas de $P$. vivax. Nós utilizamos como base para os desenhos de nossos genes, na região 5', sequiências de nucleotídeos que codificam 77 aminoácidos (aa) altamente conservados da porção N-terminal da PvCSP:

THCGHNVDLSKAINLNGVNFNNVDASSLGAAHVGQSASRGRGLGENPDDEEGDAKKK KDGKKAEPKNPRENKLKQPG

Na região 3’ dos genes, nós utilizamos como base, sequiências de nucleotídeos que codificam 75 aa altamente conservados da porção C-terminal da PvCSP:

\section{GGNAGGQGQNNEGANAPNEKSVKEYLDKVRATVGTEWTPCSVTCGVGVRVRRRVNA ANKKPEDLTLNDLETDVCT}

As regiões centrais de cada gene contém seqüências de nucleotídeos que codificam as repetições de aa características de cada variante de $P$. vivax, individualmente ou todas juntas num mesmo polipeptídeo. Estas regiões estão coloridas nos esquemas abaixo e representam: VK210$\left(\text { DRADGQPAG) }{ }_{2}(\text { DRAAGQPAG) })_{2} \text { DRADGQPAGD, VK-247- (APGANQEGGAA }\right)_{4}$ e Vivaxlike- (ANGAGNQPG) . $_{\text {. }}$

$\mathrm{Na}$ figura 10 está sendo representada a PvCSP mostrando as regiões $\mathrm{N}$ - e C-terminal conservadas, para as três diferentes formas alélicas desta proteína, e um domínio central com variação na sequência de aa. 


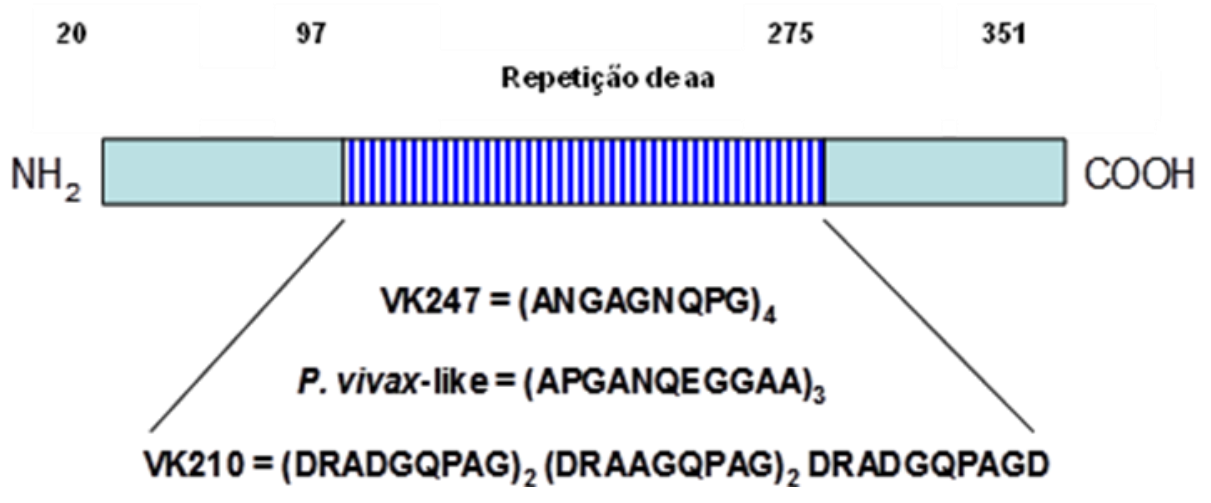

Figura 10: Representação esquemática da CSP do $P$. vivax e as seqüências das regiões centrais com repetições de aa presentes em cada forma alélica (VK210, VK247 e Vivax-like).

Genes sintéticos com códons otimizados para expressão em E. coli foram introduzidos no vetor de expressão pET-28a que contém uma sequência que codifica para uma cauda de hexahistina $\left(\mathrm{His}_{6}\right)$. Desta forma sintetizamos genes que juntamente com o vetor, codificam as seguintes proteínas:

\section{1) His 6 -PvCSP-VK210}

$\begin{array}{rrrrrr}1 \underline{0} & 2 \underline{0} & 3 \underline{0} & 4 \underline{0} & 5 \underline{0} & 6 \underline{0} \\ \text { MGSSHHHHHH } & \text { SSGLVPRGSH } & \text { MTHCGHNVDL } & \text { SKAINLNGVN } & \text { FNNVDASSLG } & \text { AAHVGQSASR }\end{array}$

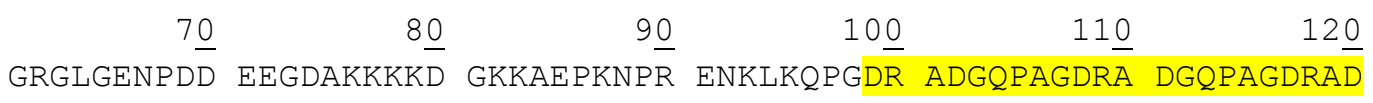

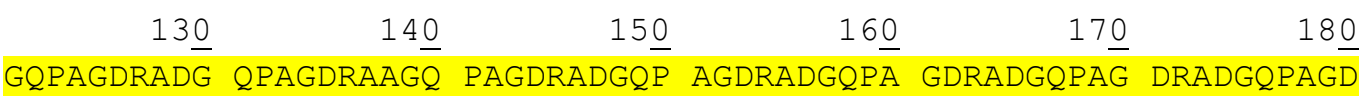

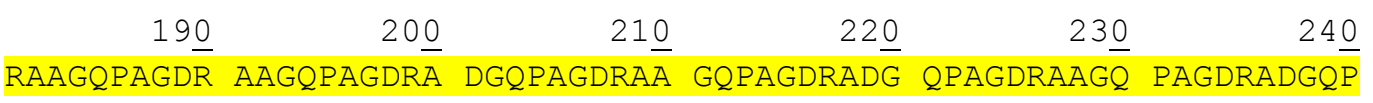

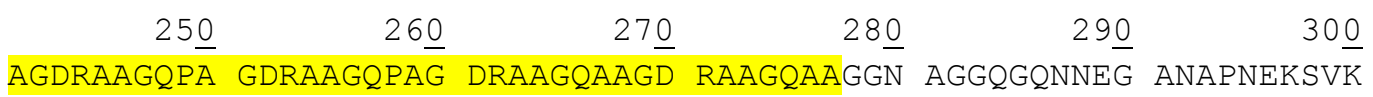

$\begin{array}{rrrrr}31 \underline{0} & 32 \underline{0} & 33 \underline{0} & 34 \underline{0} & 35 \underline{0} \\ \text { EYLDKVRATV } & \text { GTEWTPCSVT } & \text { CGVGVRVRRR VNAANKKPED } & \text { LTLNDLETDV CT }\end{array}$

pI e PM teóricos: 5.70 / 35207.42 


\section{2) His $_{6}$-PvCSP-VK247}

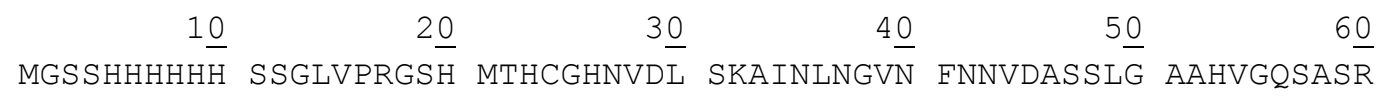

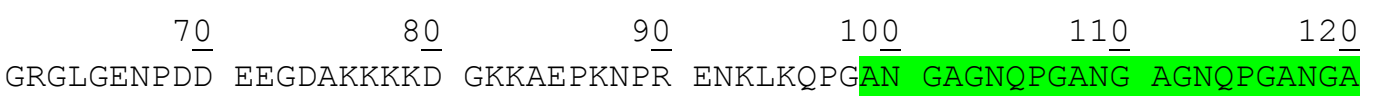

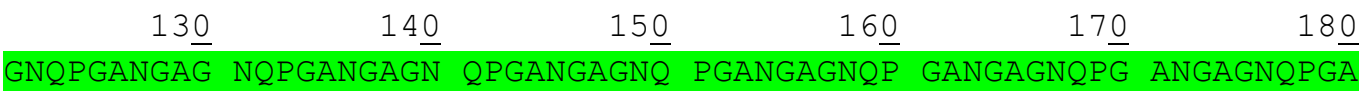

$\begin{array}{rrrrr}19 \underline{0} & 20 \underline{0} & 21 \underline{0} & 22 \underline{0} & 23 \underline{0}\end{array}$

$25 \underline{0} \quad 26 \underline{0} \quad 27 \underline{0} \quad 28 \underline{0} \quad 29 \underline{0} \quad 30 \underline{0}$

PGANGAGNQP GANGAGNQPG ANGAGNQPGA NGAGNQPGGN AGGQGQNNEG ANAPNEKSVK

$\begin{array}{rrrrr}31 \underline{0} & 32 \underline{0} & 33 \underline{0} & 34 \underline{0} & 35 \underline{0} \\ \text { EYLDKVRATV } & \text { GTEWTPCSVT } & \text { CGVGVRVRRR } & \text { VNAANKKPED } & \text { LTLNDLETDV }\end{array}$

pI e PM teóricos: 8.68 / 33633.48

\section{3) His 6 -PvCSP-Vivax-like}

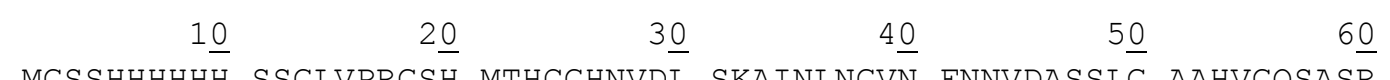

MGSSHHHHHH SSGLVPRGSH MTHCGHNVDL SKAINLNGVN FNNVDASSLG AAHVGQSASR

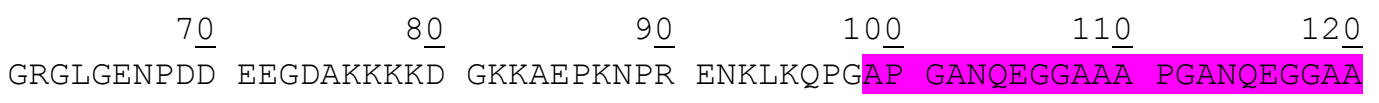

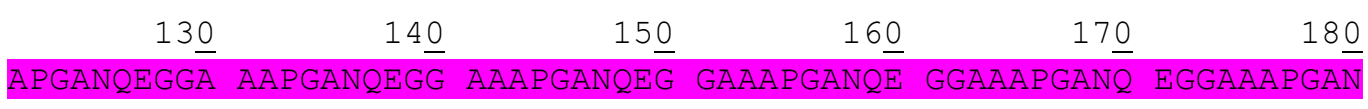

$19 \underline{0} 20 \underline{0} \quad 21 \underline{0} \quad 22 \underline{0} \quad 23 \underline{0} \quad 24 \underline{0}$

QEGGAAAPGA NQEGGAAAPG ANQEGGAAAP GANQEGGAAA PGANQEGGAA APGANQEGgA

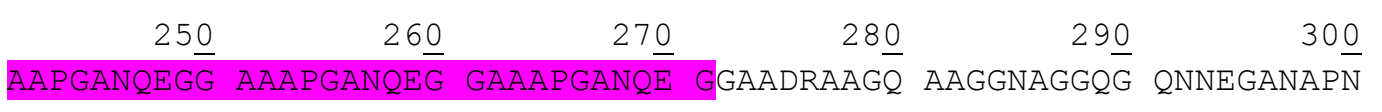

$31 \underline{0} \quad 32 \underline{0} \quad 33 \underline{0} \quad 34 \underline{0} \quad 35 \underline{0}$

EKSVKEYLDK VRATVGTEWT PCSVTCGVGV RVRRRVNAAN KKPEDLTLND LETDVCT

pI e PM teóricos: 5.23 / 33878.94

Foi desenhado um quarto gene que codifica para uma proteína híbrida contendo as três diferentes regiões repetidas da PvCSP. 


\section{4) His 6 -PvCSP-All-CS-epitopes}

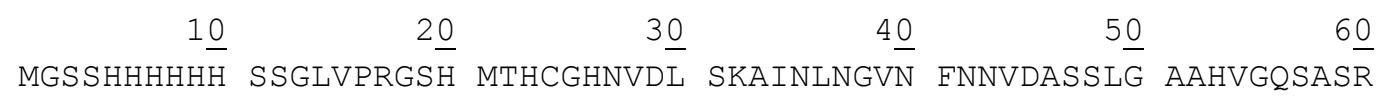

$\begin{array}{rrrrrr}7 \underline{0} & 8 \underline{0} & 9 \underline{0} & 10 \underline{0} & 11 \underline{0} & 12 \underline{0} \\ \text { GRGLGENPDD } & \text { EEGDAKKKKD } & \text { GKKAEPKNPR } & \text { ENKLKQPGPG } & \text { DRADGQPAGD } & \text { RADGQPAGDR }\end{array}$

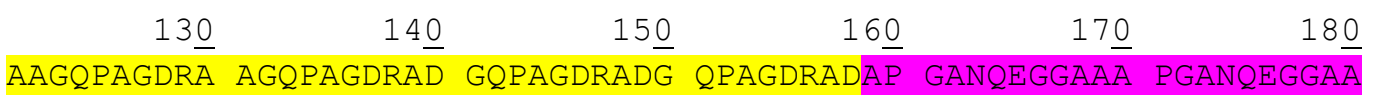

$19 \underline{0} \quad 20 \underline{0} \quad 21 \underline{0} \quad 22 \underline{0} \quad 23 \underline{0} \quad 24 \underline{0}$

APGANQEGGA AAAPGANQEG GAAAPGANQE GGAAAPGANQ EGGAAAANGA GNQPGANGA

$25 \underline{0} \quad 26 \underline{0} \quad 27 \underline{0} \quad 28 \underline{0} \quad 29 \underline{0} \quad 30 \underline{0}$

NQPGANGAGN QPGANGAGNQ PGANGAGNQP GDRAAGQAAG GNAGGQGQNN EGANAPNEKS

$\begin{array}{rrrrr}31 \underline{0} & 32 \underline{0} & 33 \underline{0} & 34 \underline{0} & 35 \underline{0} \\ \text { VKEYLDKVRA } & \text { TVGTEWTPCS VTCGVGVRVR } & \text { RRVNAANKKP } & \text { EDLTLNDLET } & \text { DVCT }\end{array}$

pI e PM teóricos: 5.69 / 34346.40

\subsection{Expressão e purificação das proteínas recombinantes bacterianas representando as diferentes variantes alélicas da PvCSP}

As proteínas recombinantes denominadas His $_{6}-\mathrm{PvCSP}-\mathrm{VK} 210$, His 6 -PvCSP-VK247, His $_{6}$-PvCSP-Vivax-like, His ${ }_{6}$-PvCSP-All-CS-epitopes foram expressas em E.coli cepa BL21DE3. Nenhuma das proteínas expressas se apresentou na fração solúvel. Foi necessária para solubilização a adição de $8 \mathrm{M}$ uréia. As proteínas foram então purificadas por cromatografia de afinidade em resina $\mathrm{Ni}^{2+}{ }_{-}$NTA seguida de cromatografia de troca iônica como descrito em Materiais e Métodos. A figura 11 A mostra que em condições redutoras as proteínas recombinantes migram em 10\% de SDS-PAGE com peso molecular (PM) aparente >50KDa.

Com a finalidade de verificar se as proteínas recombinantes purificadas por cromatografia de afinidade eram realmente as nossas proteínas de interesse ( His $_{6}$-PvCSP-VK210, His $_{6}$-PvCSPVK247, His 6 -PvCSP-Vivax-like, His 6 -PvCSP-All-CS-epitopes), foi realizado o ensaio imunoblot utilizando o AC policlonal anti-His ${ }_{6}$ (anti-cauda de hexa histidina). Observamos que o anticorpo (Ac) foi capaz de reconhecer as quatro proteínas testadas, indicando que elas eram as proteínas de interesse, uma vez que também se apresentaram com o peso molecular (PM) aparente $>50 \mathrm{KDa}$ (figura $11 \mathrm{~B}$ ). 


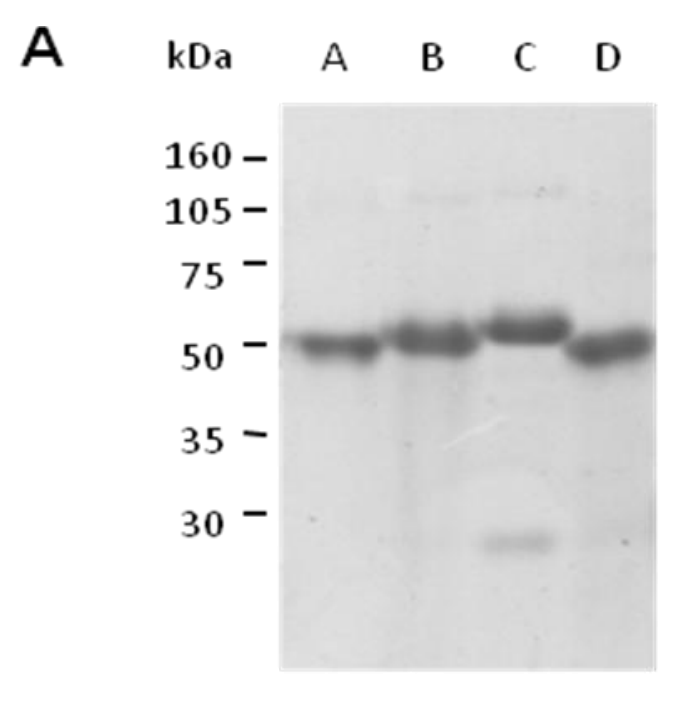

B

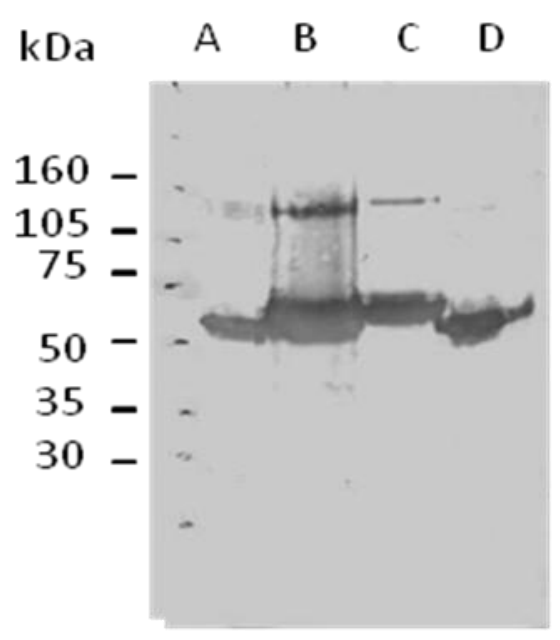
A $-\mathrm{His}_{6}-\mathrm{P} \vee \mathrm{CS}-\mathrm{VK} 210$
B - $\mathrm{His}_{6}-\mathrm{P} \vee \mathrm{CS}-\mathrm{VK} 247$
C - His - PvCSVivax-like
D $-\mathrm{His}_{6}$-PvCSAll-CS-epitopes

Figura 11: Proteínas recombinantes PvCSP. (A) Peso molecular (PM) aparente em SDSPAGE das proteínas recombinantes purificadas. Foi adicionado no gel cerca de $2 \mu \mathrm{g}$ de cada proteína por amostra, e o gel foi corado com Comassie blue. (B) Ensaio de Immunoblot das proteínas purificadas utilizando Ac específico para a sequência da cauda de hexa histidinas (His ${ }_{6}$ ). Foi adicionado no SDS-PAGE cerca de $2 \mu \mathrm{g}$ de cada proteína por amostra.

Para determinar se as proteínas recombinantes continham os epítopos imunodominantes da PvCSP, testamos por ELISA o reconhecimento destas proteínas através do uso de Ac. Na figura $12 \mathrm{~A}$ observamos que o Ac policlonal anti-His 6 foi capaz de reconhecer igualmente as quatro proteínas recombinantes: His $_{6}$-PvCSP-VK210, His 6 -PvCSP-VK247, His 6 -PvCSP-Vivaxlike e $\mathrm{His}_{6}$-PvCSP-All-CS-epitopes. Na figura 12 B notamos que o Ac monoclonal (MAb) antiVK210 (2F2), reagiu contra as quatro proteínas recombinantes testadas, porém com melhor reconhecimento das proteínas $\mathrm{His}_{6} \mathrm{PvCSP}_{\mathrm{V}} 210$ e His 6 -PvCSP-All-CS-epitopes, devido a presença do epítopo imunodominante VK210. Houve reconhecimento cruzado com as duas outras formas alélicas, principalmente a proteína recombinante representando a forma alélica His $_{6}$-PvCSP-Vivax-like. 
A
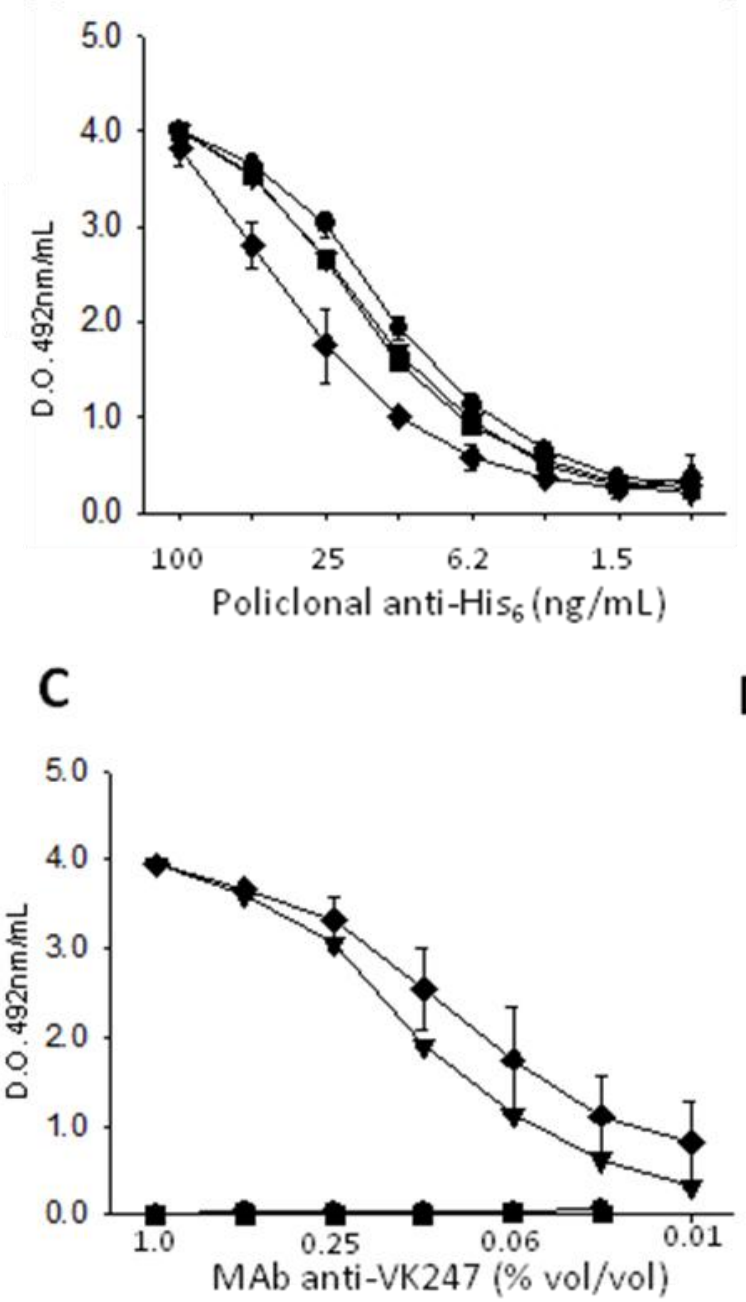

Proteínas recombinantes:

- His PvCSP-VK210

₹ His. $\mathrm{PvCSP}-\mathrm{VK} 247$

- His. PVCSP-Vivax-like

$\checkmark$ His. PvCSP-All-CS-epitopes
B

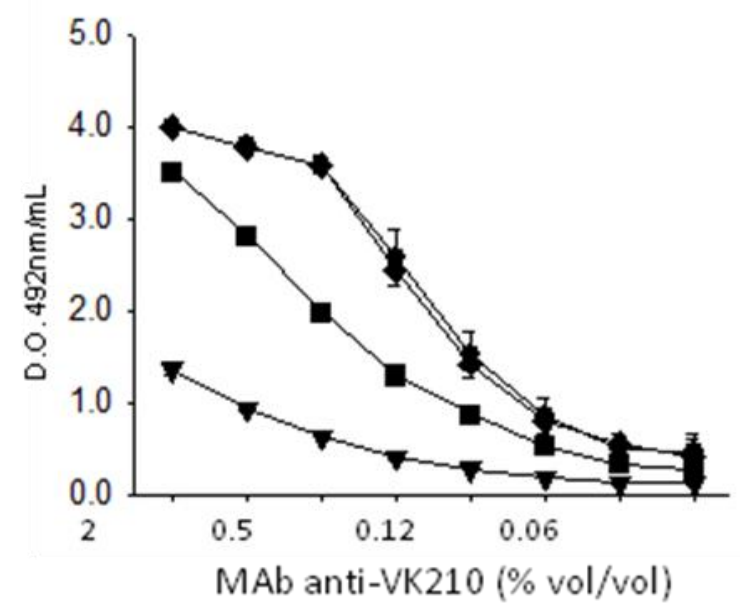

D

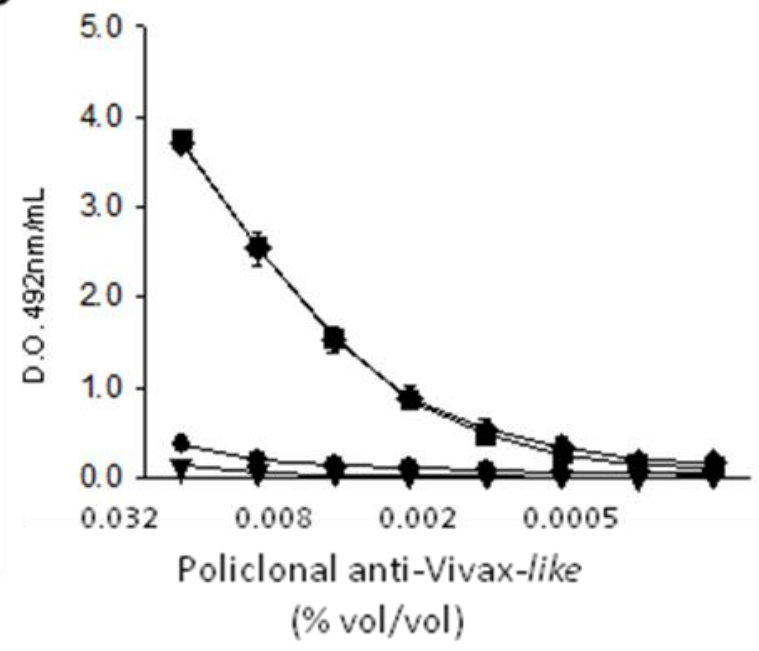

Figura 12: ELISA utilizando:

(A) Ac policlonal anti-His 6 ;

(B) MAb para o epítopo VK210 (2F2);

(C) MAb para o epítopo VK247 (2E10.E9);

(D) Ac policlonal anti-His 6 -Flic-PvCSP-Vivax-like.

Os Ac foram utilizados nas concentrações indicadas. 
A figura $12 \mathrm{C}$ mostra o reconhecimento do epítopo VK247 com o uso do MAb antiVK247 (2E10.E9) presente nas proteínas recombinantes His ${ }_{6} \mathrm{PvCSP}_{2}$-VK247 e His 6 -PvCSP-AllCS-epitopes. As duas outras formas alélicas não foram reconhecidas. Na ausência de um Ac monoclonal anti-Vivax-like, utilizamos um pool de soros de camundongos que foram imunizados com a proteína His ${ }_{6}$-Flic-PvCSP-Vivax-like (Camacho, 2012), que contêm somente Ac contra o epítopo imunodominante Vivax-like da PvCSP. Este anti-soro reagiu especificamente com as proteínas His $_{6}$-PvCSP-Vivax-like ou His ${ }_{6}$-PvCSP-All-CS-epitopes (figura 12 D). As duas outras formas alélicas não foram reconhecidas.

Com estes resultados concluímos que cada uma das proteínas expressa um dos epítopos imunodominantes da PvCSP. Importante foi o fato de que, como por nós planejado, a proteína His $_{6}$-PvCSP-All-CS-epitopes expressa todos os três epítopos imunodominantes.

\subsection{Imunogenicidade em camundongos imunizados com as diferentes formulações vacinais contendo as proteínas recombinantes representando as distintas formas alélicas da PvCSP}

Para a caracterização das propriedades imunogênicas destas proteínas recombinantes purificadas, camundongos C57BL/6 foram imunizados três vezes pela via subcutânea (s.c.) com intervalos de 3 semanas entre cada dose (figura 13A). Em cada dose foram administradas $10 \mu \mathrm{g}$ de cada proteína recombinante $\mathrm{His}_{6} \mathrm{PvCSP}-\mathrm{VK} 210$ ou $\mathrm{His}_{6} \mathrm{PvCSP}_{\mathrm{P}} \mathrm{VK} 247$ ou His ${ }_{6} \mathrm{PvCSP}-\mathrm{Vivax}-$ like ou $30 \mu \mathrm{g}$ da proteína com os três epítopos fusionados geneticamente, His ${ }_{6} \mathrm{PvCSP}-\mathrm{All}-\mathrm{CS}$ epitopes, na presença dos adjuvantes CFA/IFA ou Poly(I:C).

Assim, os diferentes grupos foram:

1) Somente Adjuvante

2) $10 \mu \mathrm{g} \mathrm{de}$ His $_{6}-\mathrm{PvCSP}-\mathrm{VK} 210$

3) $10 \mu \mathrm{g}$ de His $_{6}$-PvCSP-VK247

4) $10 \mu \mathrm{g}$ de $\mathrm{His}_{6}$-PvCSP-Vivax-like

5) $10 \mu \mathrm{g} \mathrm{de} \mathrm{His}_{6}-\mathrm{PvCSP}-\mathrm{VK} 210+$

$10 \mu \mathrm{g}$ de His $_{6}$-PvCSP-VK247 +

$10 \mu \mathrm{g}$ de His $_{6}$-PvCSP-Vivax-like

6) $30 \mu \mathrm{g}$ de His $_{6}$-PvCSP-All-CS-epitopes

No primeiro experimento utilizamos como adjuvante o padrão ouro da imunologia representado pelos adjuvantes Completo e Incompleto de Freund (CFA/IFA) para compor as 
formulações vacinais a serem testadas. Camundongos C57BL/6 foram imunizados com três doses vacinais, a cada 21 dias, pela via s.c., e seus soros foram analisados de acordo com o cronograma descrito na figura 13A. Nestes animais foram detectados Ac contra cada uma das diferentes proteínas recombinantes. Os camundongos que foram imunizados com as proteínas recombinantes, tanto individualmente quanto misturadas, na presença dos adjuvantes CFA/IFA desenvolveram altos títulos de Ac do tipo IgG, e estes títulos se mantiveram altos até a última medição feita com mais de 180 dias após a primeira imunização (figuras 13B-D). Portanto, estes títulos alcançaram seu valor máximo. Podemos afirmar que os AC detectados foram específicos para as proteínas recombinantes, já que os animais que receberam somente adjuvante (Grupo 1) não apresentaram Ac específicos.

Com as comparações dos títulos de Ac pudemos concluir que todos os três tipos de imunizações feitas foram equivalentes na indução de Ac contra as proteínas His ${ }_{6} \mathrm{PvCSP}-\mathrm{VK} 210$, $\mathrm{His}_{6} \mathrm{PvCSP}-\mathrm{VK} 247$ e His ${ }_{6} \mathrm{PvCSP}-$ Vivax-like. Assim, os títulos foram semelhantes em animais que receberam somente uma proteína, as três proteínas misturadas ou contendo a proteína que possui todos os epítopos em fusão (His ${ }_{6} \mathrm{PvCSP}-\mathrm{All}-\mathrm{CS}$ epitopes).

No segundo experimento utilizamos o adjuvante Poly(I:C), agonista do receptor tipo Toll 3 (TLR3), e que vem sendo testado para uso em seres humanos (Caskey et al., 2011). Os camundongos foram imunizados seguindo o mesmo esquema de imunização do experimento anterior (figura 13A). Nos camundongos que foram imunizados com as proteínas recombinantes, tanto individualmente quanto misturadas, na presença do adjuvante Poly(I:C) foram detectados Ac contra cada uma das diferentes proteínas recombinantes, e estes desenvolveram altos títulos de Ac do tipo IgG. Os resultados obtidos neste segundo experimento foram distintos dos observados com as imunizações utilizando CFA/IFA. Os títulos de Ac do tipo IgG apresentaram aumento significativo em muitos casos após a terceira dose vacinal (figura 13E-G). Os títulos de Ac dos camundongos que receberam a formulação vacinal contendo as três proteínas recombinantes misturadas, His 6 -PvCSP-VK210, His ${ }_{6}$-PvCSP-VK247, His 6 -PvCSP-Vivax-like, se mantiveram altos até a última medição feita com mais de 180 dias após a primeira imunização. Estes animais apresentaram consistentemente títulos ligeiramente mais altos que os animais imunizados com somente uma das proteínas recombinantes. O mais importante foi o fato de que estes animais apresentaram títulos de Ac significativamente mais altos que os animais imunizados com a proteína recombinante His 6 -PvCSP-All-CS-epitopes. Esta observação pode ser notada para todas as três diferentes formas alélicas da PvCSP.

As comparações entre os títulos de Ac obtidos dos soros dos camundongos imunizados com as três proteínas misturadas e dos soros dos camundongos imunizados com a proteína 
contendo os três epítopos fusionados geneticamente, $\mathrm{His}_{6} \mathrm{PvCSP}-\mathrm{All}-\mathrm{CS}$-epitopes, após a terceira dose vacinal, demonstram que (figura 14):

i) Quando as formulações vacinais continham os adjuvantes CFA/IFA, os títulos de Ac obtidos foram similares, não apresentando diferenças estatísticas significativas;

ii) Quando as formulações vacinais continham o adjuvante Poly(I:C), os títulos de Ac obtidos dos animais que receberam as três proteínas misturadas na mesma formulação foram maiores se comparados aos animais que receberam cada proteína isoladamente ou a proteína $\mathrm{His}_{6} \mathrm{PvCSP}$-All-CS-epitopes, apresentando diferença estatística $(\mathrm{p}<0,01)$.

Comparando os títulos de Ac induzidos nos animais imunizados com as três proteínas misturadas na presença tanto dos adjuvantes CFA/IFA quanto Poly(I:C), concluímos que estas formulações induziram títulos de Ac similares. Porém, a formulação vacinal contendo a proteína recombinante $\mathrm{His}_{6} \mathrm{PvCSP}-\mathrm{All}-\mathrm{CS}$ epitopes induz títulos de $\mathrm{AC}$ maiores quando usada na presença dos adjuvantes CFA/IFA (figura 14).

A fim de determinarmos se doses menores dos antígenos recombinantes seriam efetivas para a indução de altos títulos de Ac específicos, camundongos C57BL/6 foram imunizados com doses contendo 10 ou $1 \mu \mathrm{g}$ de cada proteína recombinante. Assim, o total da mistura de proteínas recombinantes por camundongos foi de 30 ou $3 \mu \mathrm{g}$, na presença de $50 \mu \mathrm{g}$ do adjuvante Poly(I:C).

Assim, os diferentes grupos foram:

1) $\operatorname{Poly}(\mathrm{I}: \mathrm{C})$

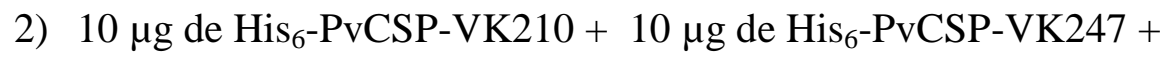
$10 \mu \mathrm{g}$ de His $_{6}$-PvCSP-Vivax-like + Poly(I:C)

3) $1 \mu \mathrm{g}$ de His $_{6}-\mathrm{PvCSP}-\mathrm{VK} 210+1 \mu \mathrm{g}$ de $\mathrm{His}_{6}-\mathrm{PvCSP}-\mathrm{VK} 247+$

$1 \mu \mathrm{g}$ de His $_{6}$-PvCSP-Vivax-like + Poly(I:C)

O esquema de imunização e análise seguiu o cronograma descrito na figura 15A. As formulações vacinais com $30 \mu \mathrm{g}$ ou $3 \mu \mathrm{g}$ de proteínas induziram títulos similares de Ac IgG específicos contra as três diferentes formas alélicas da PvCSP e que se mantiveram altos durante o período analisado. $\mathrm{O}$ resultado indica que doses menores de proteínas recombinantes são eficazes (figura 15B-D). 

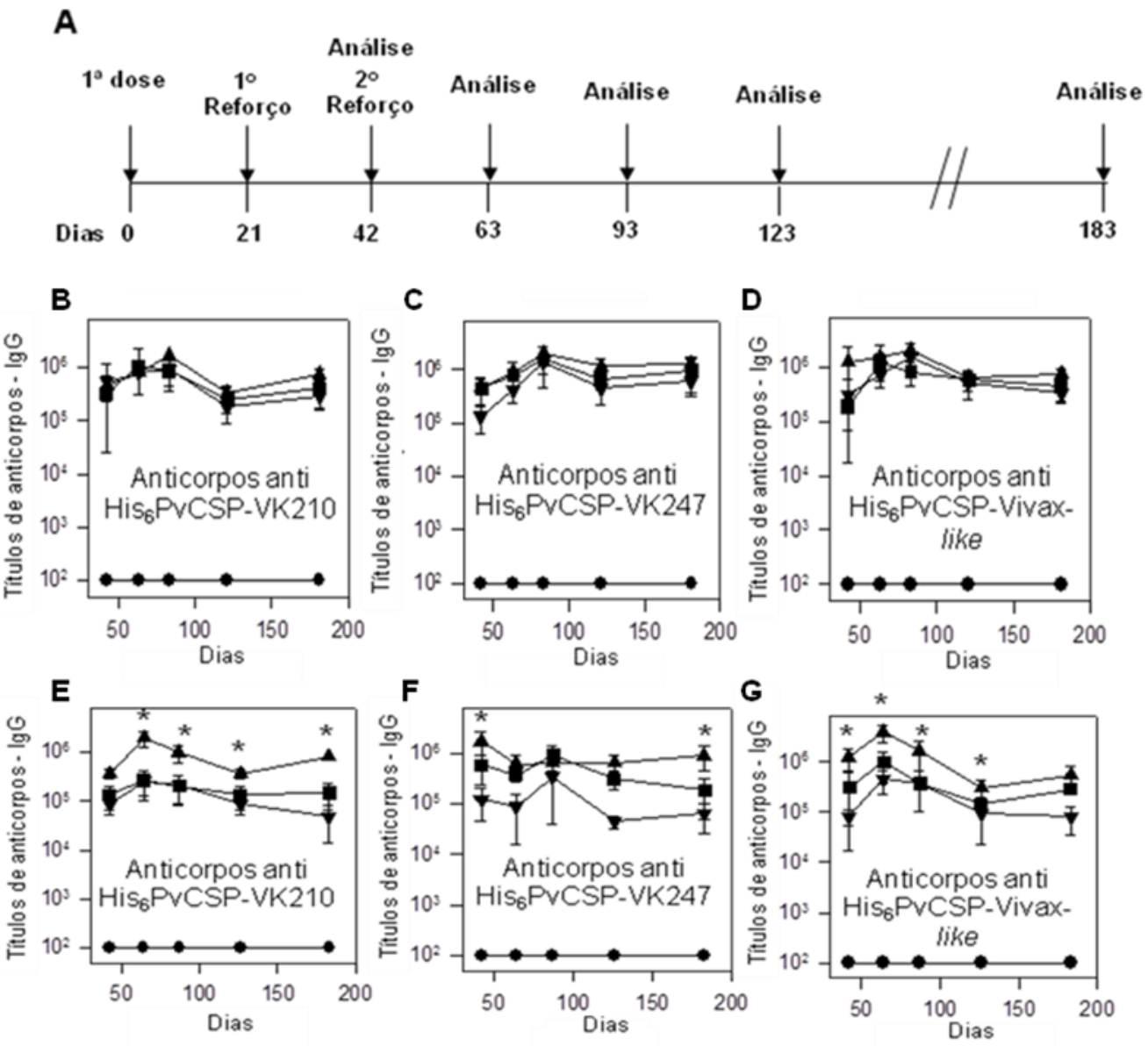

Imunizaçōes:

Adjuvantes usados nas imunizações:

- Adjuvante

- Uma Proteína

B - D CFA/IFA

A Três proteínas misturadas * $\mathrm{P}<.01$

E-G Poly $(l: C)$

v His ${ }_{6}$ PvCSP-All-CS-epitopes

Figura 13: Títulos de Ac séricos (IgG) induzidos nos camundongos C57BL/6 imunizados com as diferentes formulações vacinais (indicadas na legenda). (A) Camundongos foram imunizados três vezes, pela via s.c., com intervalos de 21 dias. Os títulos de Ac foram analisados de acordo com o cronograma. (B - D) Camundongos foram imunizados na presença dos adjuvantes CFA/IFA ou CFA/IFA + His $_{6}$-PvCSP-VK210 ou CFA/IFA + His 6 -PvCSP-VK247 ou CFA/IFA + His $_{6}$-PvCSP-Vivax-like ou CFA/IFA + mistura de proteínas (His ${ }_{6}$-PvCSP-VK210 + His $_{6}$-PvCSP-VK247+ His 6 -PvCSP-Vivax-like) ou CFA/IFA + His 6 -PvCSP-All-CS-epitopes. (E - G) Camundongos foram imunizados da mesma forma acima citada, porém na presença do adjuvante Poly(I:C). Asteriscos denotam diferenças significativas encontradas entre os grupos de camundongos imunizados (One-Way ANOVA; TuKey HSD; p<0.01). Resultados expressos como média \pm S.D. (n=6/grupo). 

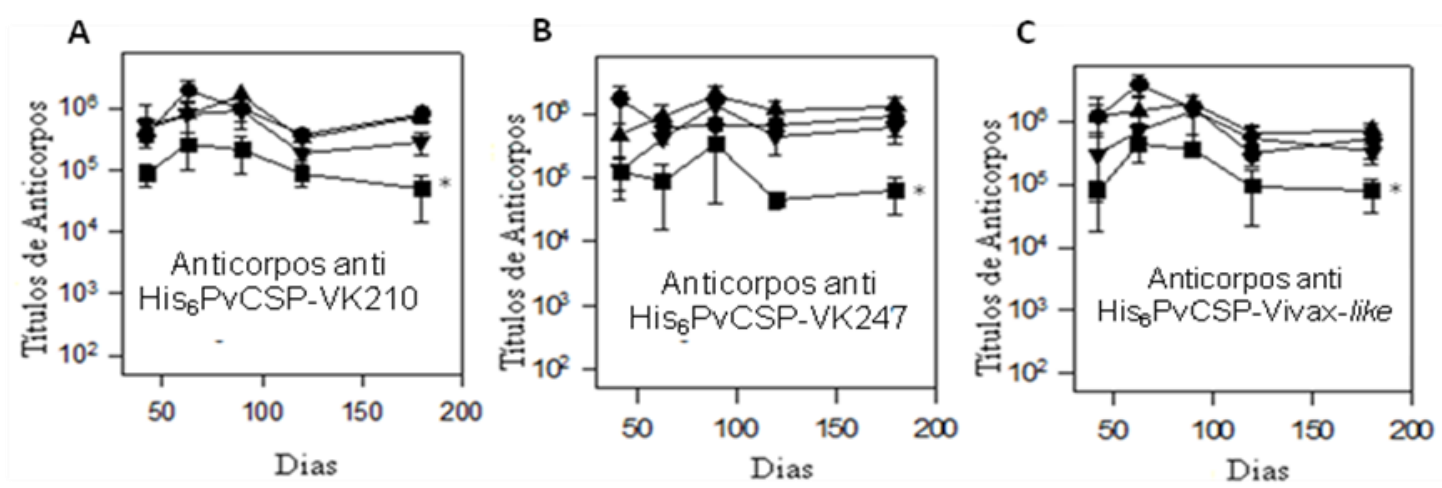

Imunizações:

- Três proteínas misturadas + Poly $(\mathrm{I}: \mathrm{C})$

- His ${ }_{6}$ PvCSP-All-CS-epitopes + Poly $(\mathrm{I}: \mathrm{C}){ }^{*} \mathrm{P}<.01$

$\Delta$ Três proteinas misturadas + CFA

$\boldsymbol{\nabla} \mathrm{His}_{6}$ PvCSP-All-CS-epitopes + CFA

Figura 14: Comparação entre os títulos de Ac nos soros dos camundongos C57BL/6 imunizados com as três proteínas misturadas na presença dos adjuvantes Poly(I:C) ou CFA/IFA, e dos soros dos camundongos C57BL/6 imunizados com His 6 PvCSP-All-CSepitopes, na presença dos mesmos adjuvantes, após a terceira dose vacinal. (A) Títulos de Ac obtidos contra a proteína His $_{6}$-PvCSP-VK210, (B) contra a proteína His ${ }_{6}$-PvCSP-VK247, e (C) contra a proteína His $_{6}-\mathrm{PvCSP}-$ Vivax-like. Asteriscos mostram a diferença significativa encontrada entre os grupos de camundongos imunizados (One-Way ANOVA; TuKey HSD; $\mathrm{p}<0.01)$. Resultados expressos como média \pm S.D.

Devido ao fato de que proteínas recombinantes bacterianas sempre contêm resíduos de LPS, imunizamos camundongos geneticamente deficientes (Knockout - KO) para o Toll-like receptor 4 (TLR4). O esquema de imunização seguiu o cronograma descrito na figura 16A. Camundongos C57BL/6 $\left(\mathrm{tlr} 4^{+/+}\right.$) ou $\mathrm{tlr} 4^{-/-}$foram imunizados com formulações vacinais contendo uma proteína não relacionada ao $P$. vivax, flagelina recombinante, na presença de $50 \mu \mathrm{g}$ do adjuvante Poly(I:C), ou com formulações vacinais contendo uma mistura das três proteínas recombinantes PvCSP, na presença do mesmo adjuvante.

Assim, os diferentes grupos foram:

1) $\mathrm{tlr}^{+/+}$- Flic Rec + Poly(I:C)

2) tlr $^{+/+}-(1 \mu \mathrm{g})$ His $_{6}$-PvCSP-VK210 + $(1 \mu \mathrm{g})$ His $_{6}$-PvCSP-VK247 + $(1 \mu \mathrm{g}) \mathrm{His}_{6}$-PvCSPVivax-like + Poly(I:C)

3) $t l r 4^{-/-}$- Flic Rec + Poly(I:C) 


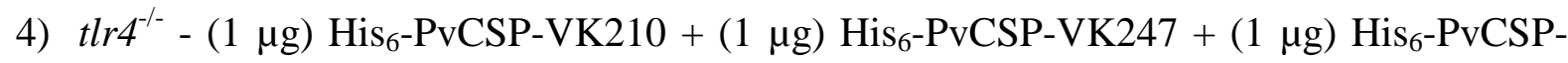
Vivax-like + Poly(I:C)

A

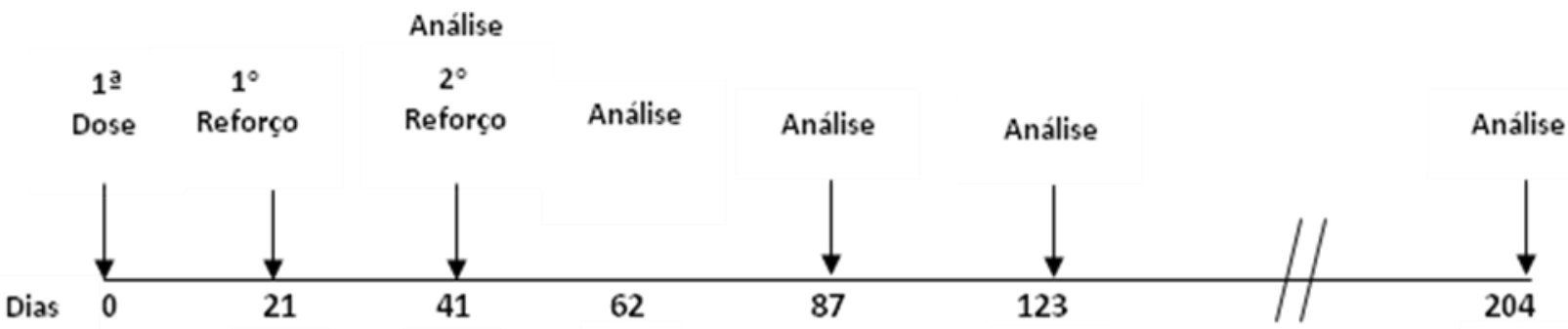

B

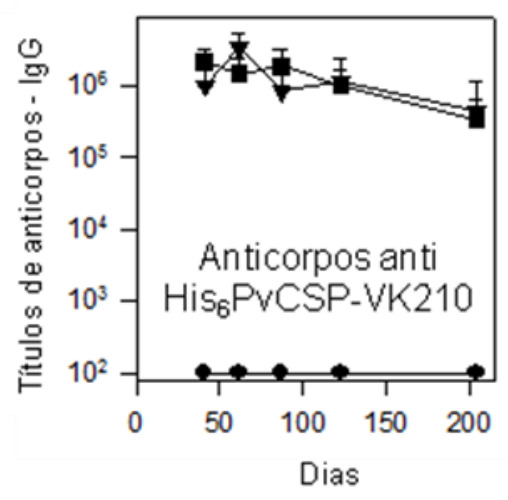

C

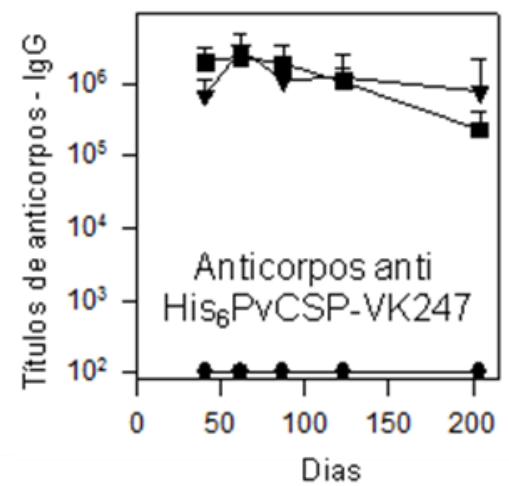

D

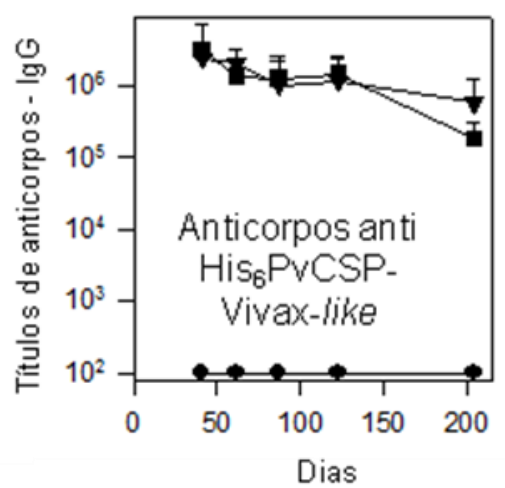

Adjuvante

V Adjuvante + mistura de proteinas PvCSP (30 mg/mou se/dose)

- Adjuvante + mistura de proteínas PVCSP (3 mg/mouse/dose)

Figura 15: Títulos de Ac séricos (IgG) induzidos nos camundongos C57BL/6 imunizados com as diferentes doses da formulação vacinal. (A) C57BL/6 foram imunizados com a mistura das três proteínas recombinantes PvCSP nas doses de $10 \mu \mathrm{g}$ ou $1 \mu \mathrm{g}$ de cada uma, na presença do adjuvante Poly(I:C), e os títulos de Ac IgG foram analisados de acordo com o cronograma. Os animais imunizados tanto com $30 \mu \mathrm{g}$ (triângulos) ou $3 \mu \mathrm{g}$ (quadrados) da mistura de proteínas PvCSP responderam igualmente bem para (B) His ${ }_{6}-\mathrm{PvCSP}_{-V K} 210$, ou (C) His ${ }_{6}-\mathrm{PvCSP}_{\mathrm{V}} \mathrm{VK} 247$, ou (D) His $_{6}$-PvCSP-Vivax-like. (One-Way ANOVA, p=NS; TuKey HSD, realizados entre os grupos experimentais, não incluindo o grupo controle). Resultados expressos como média \pm S.D. ( $n=6 /$ grupo $)$. 
A

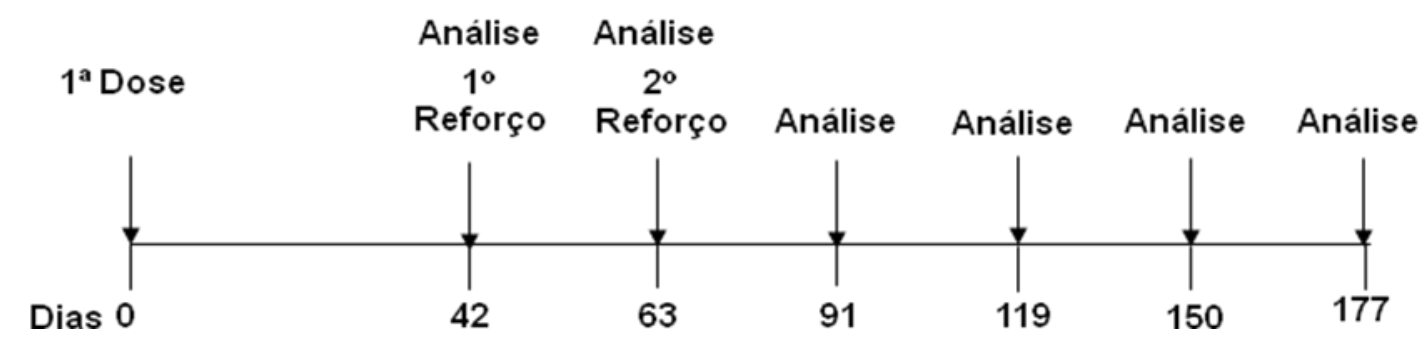

B

Anticorpo anti $\mathrm{His}_{6} \mathrm{PVCSP}-\mathrm{VK} 210$

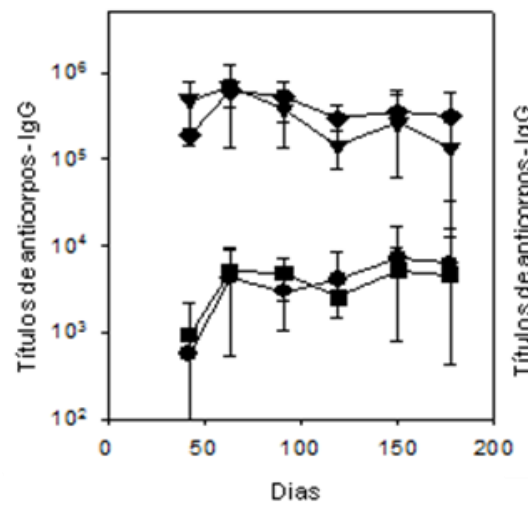

C

Anticorpo anti $\mathrm{His}_{6}$ PVCSP-VK247

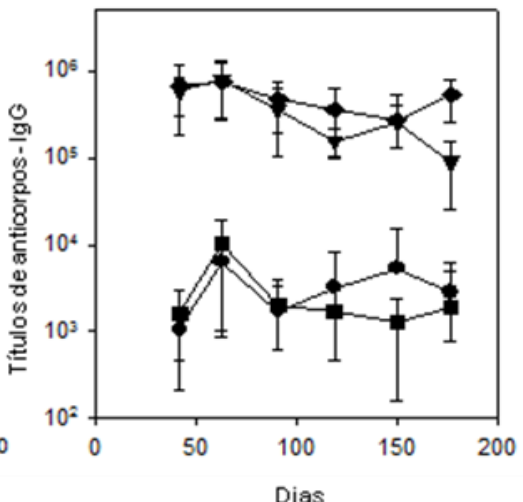

D

\section{Anticorpo anti} $\mathrm{His}_{6}$ PVCSP-Vivax-like

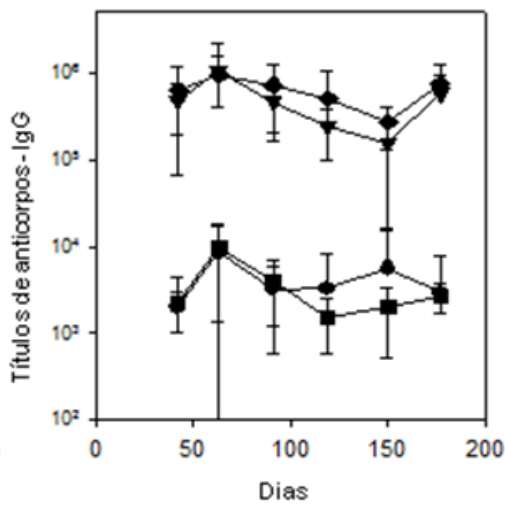

Animall Antigeno

- tir $^{+/+} / \mathrm{FliC}$

- tir $^{t /+} /$ Mistura de proteínas PVCSP

- $\operatorname{tir}^{-6} / \mathrm{FliC}$

- tir $^{-/} /$Mistura de proteínas PVCSP

Figura 16: Títulos de Ac séricos (IgG) induzidos nos camundongos C57BL/6 $\mathrm{tlr}^{+/+}$ou $\mathrm{tlr}^{-/-}$ imunizados com as proteínas recombinantes da PvCSP. (A) Camundongos foram imunizados com três doses vacinais e os títulos de Ac foram analisados de acordo com o cronograma. (B - D) Dois grupos de camundongos $t l r 4^{+/+}$ou $t l r 4^{-/-}$foram imunizados ou com flagelina recombinante $\left(\right.$ Flic Rec) + Poly(I:C), ou com Poly(I:C) + His ${ }_{6}-$ PvCSP-VK210 + His $6_{6}$ PvCSP-VK247 + His $_{6}{ }^{-}$ PvCSP-Vivax-like ( $3 \mu \mathrm{g} / \mathrm{dose} / \mathrm{animal})$. Os títulos de Ac gerados tanto em animais $\mathrm{tlr} 4^{+/+}$ou $t l r 4^{-/-}$ imunizados com a mistura de proteínas PvCSP na presença do adjuvante Poly(I:C) foram semelhantes quando testados para a presença de AC para (B) His $6^{-} \mathrm{PvCSP}_{-V K 210}$, ou (C) $\mathrm{His}_{6}{ }^{-}$ PvCSP-VK247, ou (D) His ${ }_{6}$-PvCSP-Vivax-like. (One-Way ANOVA, p=NS; TuKey HSD, realizados entre os grupos experimentais, não incluindo o grupo controle). Resultados expressos como média \pm S.D. (n=5/grupo). 
Essencialmente não observamos diferenças significativas nos títulos de Ac séricos contra qualquer uma das proteínas recombinantes testadas, quando comparamos os camundongos selvagens $t l r 4^{+/+}$e os $t l r 4^{-/-}$, imunizados com a formulação vacinal contendo a mistura das proteínas PvCSP na presença do adjuvante Poly(I:C) (figuras 16B-D). Assim, confirmamos que neste sistema não há uma interferência crítica do LPS bacteriano nos resultados obtidos após as imunizações experimentais em camundongos C57BL/6.

Adicionalmente, fizemos um experimento utilizando o adjuvante Hiltonol (Poly-ICLC), uma versão mais estável e clinicamente aprovada do adjuvante Poly(I:C), e que vem sendo testado em primatas não-humanos, e tem se mostrado mais eficiente do que este, visando uso em vacinação humana (Caskey et al., 2011; Matthews et al., 2013). Camundongos C57BL/6 foram imunizados com a mistura das três proteínas recombinantes da PvCSP, nas doses de $1 \mu \mathrm{g} / \mathrm{cada}$, na presença do adjuvante Hiltonol (Poly-ICLC) ou do adjuvante Poly(I:C) (figura 17). Os camundongos foram imunizados por três vezes, pela via s.c., de acordo com o esquema de imunização apresentado na figura 17A. Os títulos dos Ac foram analisados por ELISA por aproximadamente 190 dias após a primeira dose vacinal (figura 17A).

Através dos resultados apresentados concluímos que não houve diferença estatisticamente significativa entre os dois adjuvantes testados nos títulos de Ac específicos contra qualquer uma das três proteínas recombinantes da PvCSP (figuras 17B-D). 
A

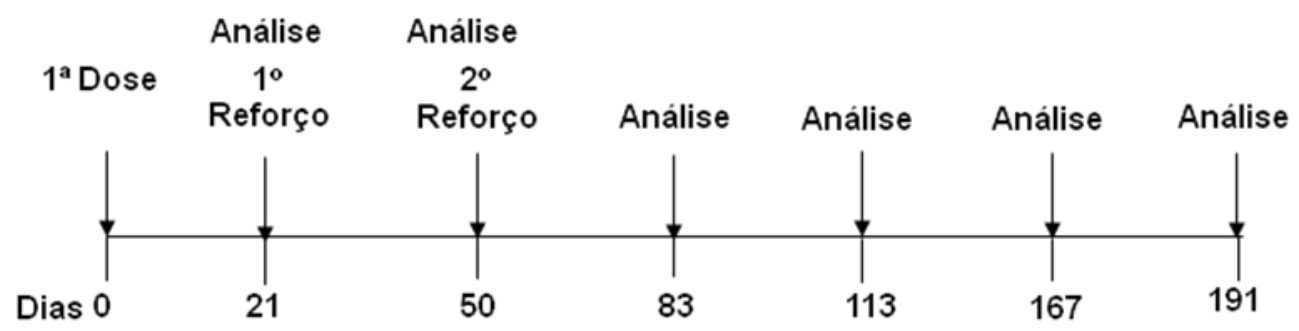

B

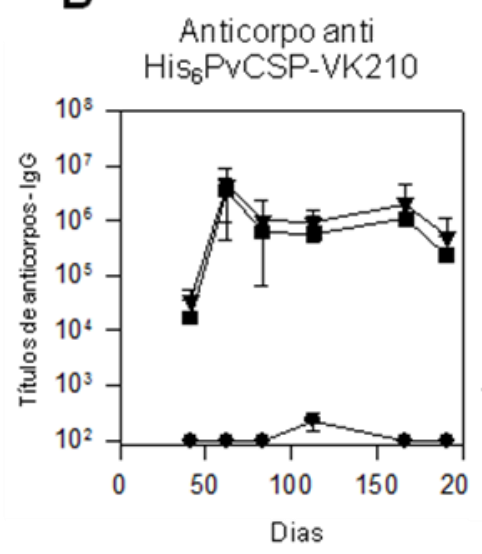

C

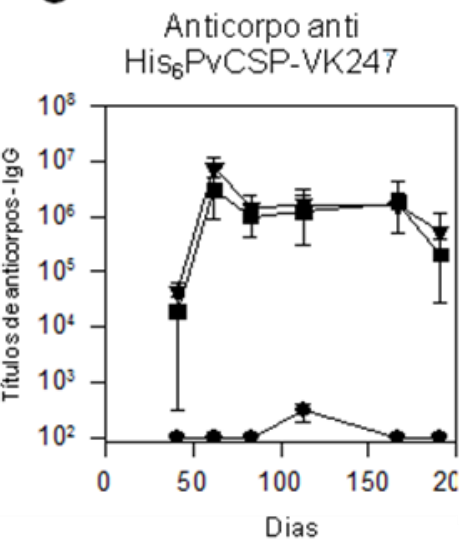

D

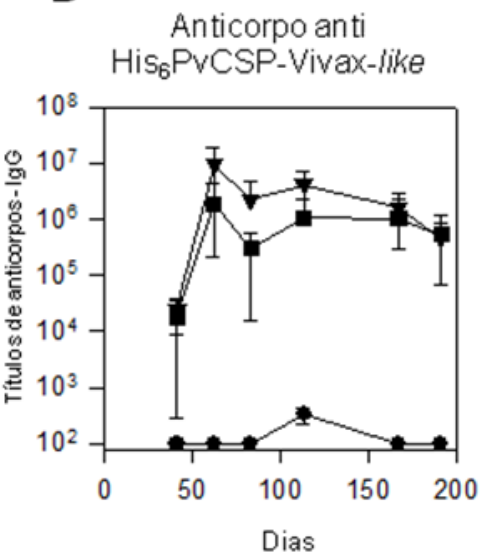

Imunizaçōes:

- Hiltonol

齐 Hiltonol + His6-PvCSP-VK210 + His6-PVCSP-VK247 + His6-PVCSP-Vivax-like (3ug)

- Poly(l:C) + His6-PvCSP-VK210 + His6-PvCSP-VK247 + His6-PvCSP-Vivax-like (3ug)

Figura 17: Comparação da resposta imune induzida na presença dos adjuvantes PolyICLC (Hiltonol) e Poly(I:C). (A) Camundongos foram imunizados com três doses vacinais pela via s.c. e os títulos de Ac foram analisados de acordo com o cronograma. (B - D) Os animais foram imunizados com formulações vacinais contendo Hiltonol, ou Hiltonol + His $_{6}$-PvCSPVK210 + His $_{6}$-PvCSP-VK247 + His $_{6}$-PvCSP-Vivax-like (3 $\mu \mathrm{g} /$ dose/animal), ou Poly(I: C) + His $_{6}$-PvCSP-VK210 + His $_{6}$-PvCSP-VK247 + His 6 -PvCSP-Vivax-like (3 $\mu \mathrm{g} /$ dose/animal). Os títulos de Ac dos animais que receberam as proteínas recombinates da PvCSP foram igualmente altos para (B) His ${ }_{6}$-PvCSP-VK210, ou (C) His 6 -PvCSP-VK247, ou (D) His 6 -PvCSP-Vivax-like. (One-Way ANOVA, p=NS; TuKey HSD, realizados entre os grupos experimentais, não incluindo o grupo controle). Resultados expressos como média \pm S.D. ( $\mathrm{n}=5$ /grupo). 


\subsection{Imunogenicidade dos adenovírus recombinantes, símio do tipo 68 e humano do tipo 5, deficientes em replicação, expressando as três regiões imunodominantes em fusão da CSP de Plasmodium vivax}

A fim de desenvolvermos protocolos de vacinação do tipo prime-boost heterólogo (adenovírus e proteína recombinantes), iniciamos estudos para a caracterização das propriedades imunogênicas de dois adenovírus recombinantes contendo o gene da PvCSP. Para tal, utilizamos os adenovírus recombinantes deficientes em replicação AdCh68 e AdHu5 expressando a PvCSP. Estes adenovírus recombinantes foram então denominados AdCh68-PvCSP e AdHu5-PvCSP, respectivamente.

A sequência da proteína expressa em cada um dos adenovírus recombinantes está descrita abaixo e representada na figura 18B:

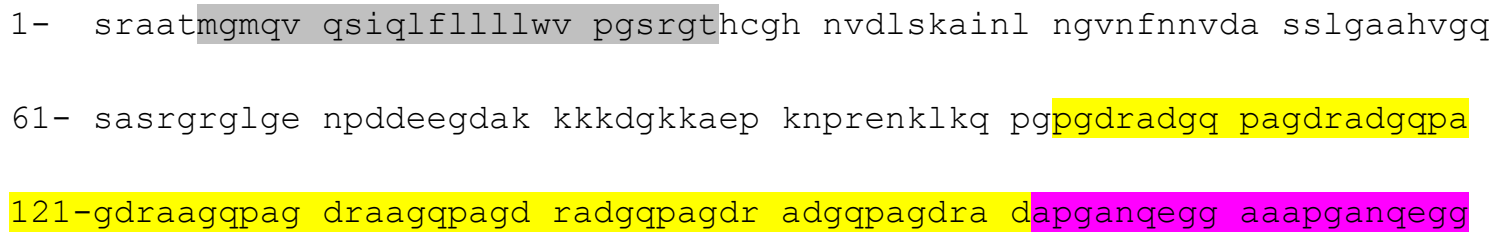

A região mgmqv qsiqlfllllwv pgsrgt representa uma sequência contendo um peptídeo sinal que visa levar a secreção da proteína. As regiões coloridas representam as diferentes regiões imunodominantes de cada uma das formas alélicas da PvCSP. A figura 18A mostra uma representação esquemática do adenovírus expressando a proteína His ${ }_{6} \mathrm{PvCSP}-\mathrm{All}-\mathrm{CS}$-epitopes, incluindo a região do peptídeo sinal. A fim de determinar se o adenovírus recombinante símio de fato expressava a proteína $\mathrm{His}_{6} \mathrm{PvCSP}$-All-CS-epitopes, fizemos ensaios de imunofluorescência indireta (IFI) utilizando FITC (figura 18C). Células HEK293a foram cultivadas com amostras purificadas e tituladas do AdCh68-PvCSP, com uma multiplicidade de infecção de 5 pfu por célula (m.o.i. 5). 
A

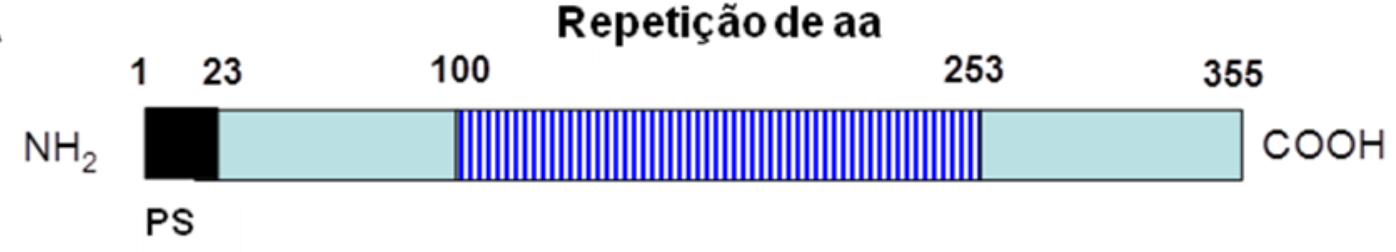

B

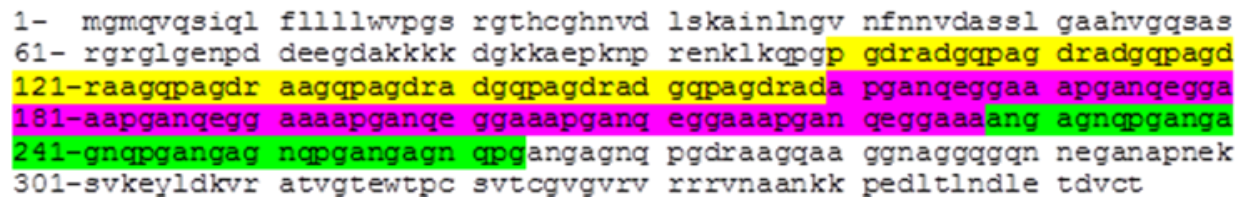

C

\section{Adeno- $\beta$ gal \\ M.O.I. 5 \\ Adeno- C68-PvCSP \\ M.O.I. 5}

\section{Contraste de Fase}
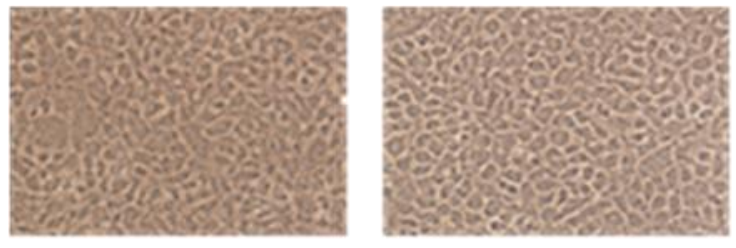

DAPI
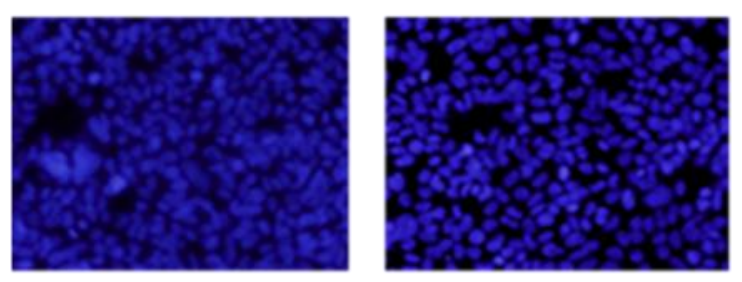

FITC
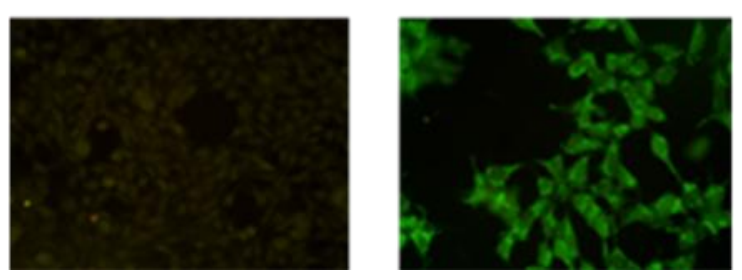

Figura 18: Adenovírus recombinantes deficientes em replicação expressando a PvCSP. (A) representação esquemática da proteína PvCSP-All-CS-epitopes expressa nos adenovírus recombinantes, incluindo um peptídeo sinal na extremidade $\mathrm{N}$-terminal da construção. (B) Sequência deduzida de aa da proteína PvCSP-All-CS-epitopes expressa nos adenovírus recombinantes. (C) Cultura de células HEK293a foi infectada com o adenovírus recombinante controle Ad $\beta$-gal ou AdCh68-PvCSP, com uma multiplicidade de infecção de 5 pfu por células (m.o.i. 5). As células foram coradas com DAPI, ou usadas em ensaios de imunofluorescência indireta (IFI) utilizando os AC específicos de animais imunizados com as três proteínas 
recombinantes da PvCSP representando as diferentes formas alélicas e seguido de conjugado anti-mouse FITC.

Os ensaios de IFI confirmaram a expressão da proteína PvCSP pelo adenovírus símio. Ensaios similares com células HEK293 infectadas com o adenovírus recombinante AdHu5PvCSP apresentaram resultados de expressão semelhantes (dados não apresentados). Utilizando estes adenovírus recombinantes, realizamos experimentos imunizando camundongos C57BL/6. Os camundongos receberam a primeira dose vacinal (prime) contendo $2 \mathrm{X} 10^{7}$ pfu/dose/camundongo dos adenovírus recombinantes AdHu5- $\beta$ gal (controle), AdCh68-PvCSP ou AdHu5-PvCSP administrados pela via i.m. (figura 19A). Após 21 dias da primeira dose vacinal medimos a resposta imune pela determinação de Ac específicos para cada uma das três formas alélicas da PvCSP, através de Elisa. Observamos que os grupos de camundongos imunizados tanto com formulações vacinais contendo AdCh68-PvCSP ou AdHu5-PvCSP responderam igualmente bem com títulos de AC na faixa de $10^{4}$ (figura 19A). Após 42 dias da primeira dose vacinal receberam uma dose vacinal reforço (boost) contendo o adjuvante Poly(I:C) $(50 \mu \mathrm{g})$, ou uma mistura das proteínas recombinantes PvCSP, His ${ }_{6}$-PvCSP-VK210 + His $_{6}$-PvCSP-VK247 + His $_{6}$-PvCSP-Vivax-like (1 $\mu \mathrm{g} /$ cada), na presença do Poly(I:C), administradas pela via s.c., com volume final da formulação de $100 \mu \mathrm{L} / a n i m a l$ (figura 19B). Após 63 dias da primeira dose vacinal medimos a resposta imune pela determinação de AC específicos para cada uma das três formas alélicas da PvCSP. Observamos que após a dose reforço (boost), houve um aumento significativo na resposta imune dos animais que foram imunizados com AdCh68-PvCSP ou AdHu5-PvCSP e que receberam a mistura das proteínas recombinantes PvCSP na presença do Poly(I:C) (Grupos 5 e 6, respectivamente - figura 19B), em relação aos outros grupos testados no experimento. Não observamos diferenças estatísticas entre os grupos 5 e 6. Os resultados demonstram claramente que os adenovírus AdCh68-PvCSP e AdHu5-PvCSP são imunogênicos capazes de induzir uma resposta primária e que esta pode ser re-estimulada num protocolo de prime-boost heterólogo com proteínas recombinantes na presença do adjuvante Poly(I:C).

Para determinarmos a longevidade desta resposta imune medida pela presença de Ac séricos específicos contra a PvCSP, imunizamos mais uma vez estes camundongos, administrando uma segunda dose reforço com formulações vacinais contendo o adjuvante Poly(I:C), ou uma mistura das proteínas recombinantes PvCSP, His 6 -PvCSP-VK210 + His $_{6}$ PvCSP-VK247 + His $_{6}$-PvCSP-Vivax-like (1 $\mu \mathrm{g} /$ cada), na presença do adjuvante Poly(I:C) (figura 20B-D). Analisamos os títulos dos Ac no soro destes camundongos imunizados com 
adenovírus recombinantes, em sistema de prime-boost heterólogo, por aproximadamente 170 dias, de acordo com o esquema de imunização observado na figura $20 \mathrm{~A}$.
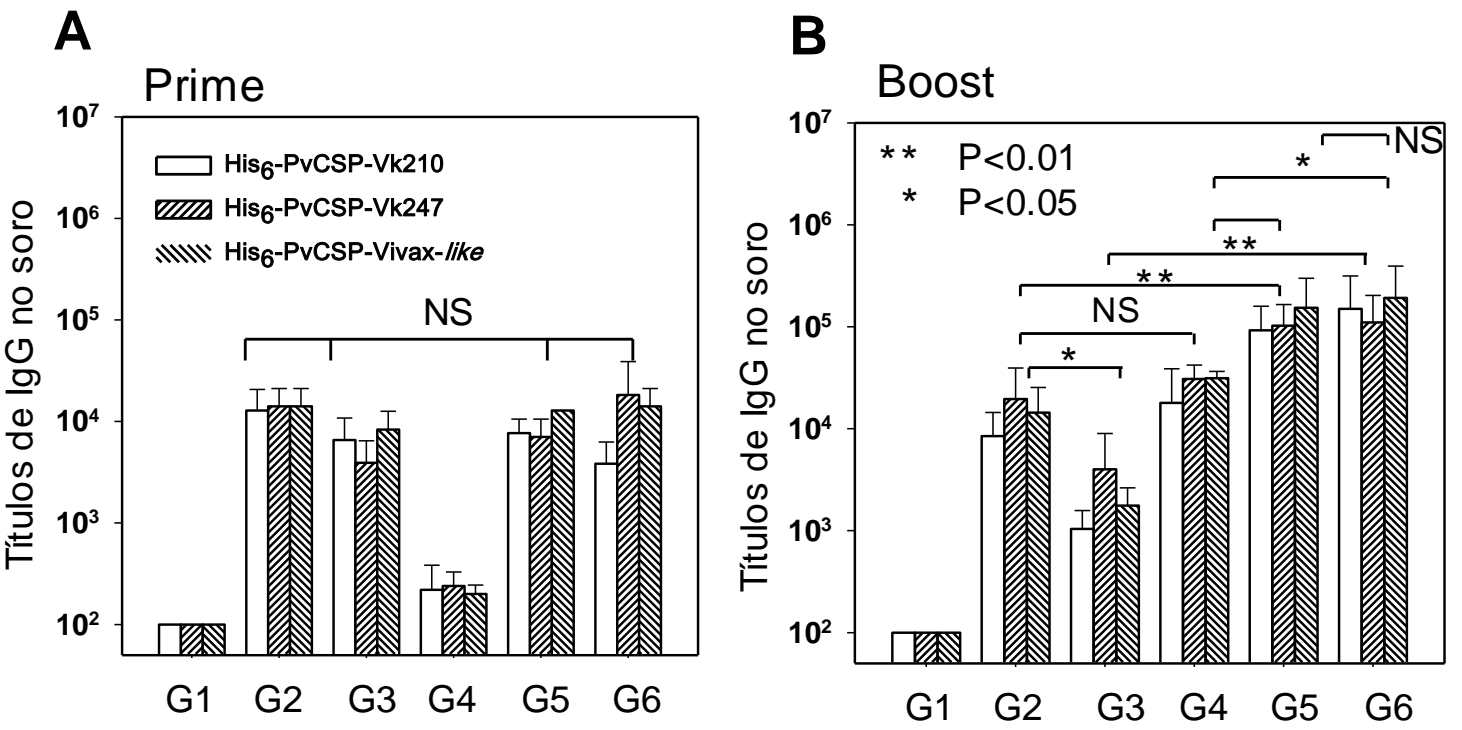

1a dose vacinal (Prime) / Reforço (Boost)

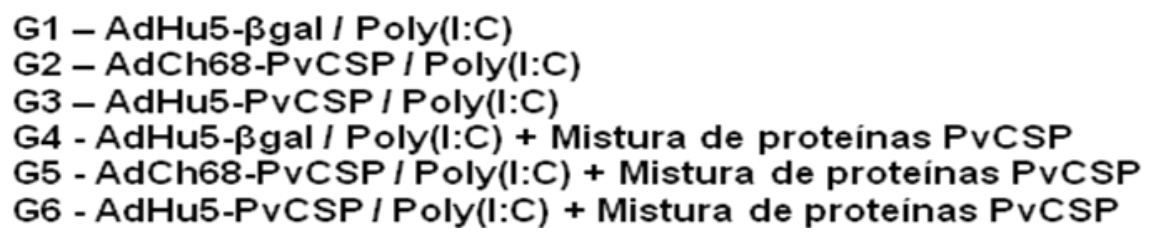

Figura 19: Indução da resposta de Ac específicos em camundongos imunizados com adenovírus recombinantes expressando PvCSP como parte de um regime de vacinação do tipo prime-boost heterólogo. (A) Camundongos C57BL/6 foram imunizados pela via i.m. com

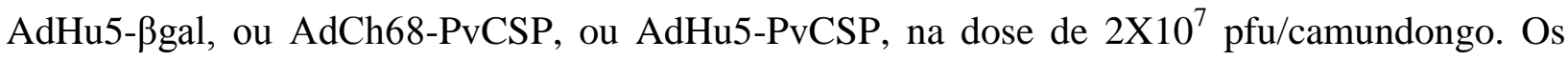
títulos de Ac IgG foram determinados 21 dias após a primeira dose vacinal (prime). (B) 42 dias após a primeira dose vacinal, os camundongos receberam uma dose reforço (boost), pela via s.c., contendo somente o adjuvante Poly(I:C), ou a mistura das proteínas recombinantes PvCSP, His $6^{-}$ PvCSP-VK210 + His $_{6}-$ PvCSP-VK247 + His 6 -PvCSP-Vivax-like, na presença do Poly(I:C). Os títulos de Ac IgG foram determinados 63 dias após a primeira dose vacinal (boost). Camundongos imunizados com AdCh68-PvCSP ou AdHu5-PvCSP + mistura das proteínas recombinantes PvCSP, na presença do Poly(I:C) (G5 e G6, respectivamente) apresentaram títulos de AC superiores aos outros grupos controles analisados (One-Way ANOVA, Tukey HSD, sendo G2 e G3 p<0.05 e G4 p<0.01). Não houve diferença estatística entre os grupos 5 e 6 $(\mathrm{p}=\mathrm{NS})$. Resultados expressos como média \pm S.D. $(\mathrm{n}=5)$. 
A fim de determinar a especificadade dos Ac contra a PvCSP utilizamos diversas proteínas recombinantes esquematizadas na figura 21A. As proteínas recombinantes que apresentam em sua porção N-terminal a flagelina de Salmonella thyphimurium (Flic), contêm somente a porção de repetição de aa central da CSP, representando cada forma alélica da PvCSP: PvCSP-VK210, PvCSP-VK247, ou PvCSP-Vivax-like. As proteínas recombinantes sem a Flic, apresentam porções conservadas entre os alelos, $\mathrm{N}$ - e C-terminal, flanqueando a região de repetição de aa central de cada variante da PvCSP: PvCSP-VK210, PvCSP-VK247, ou PvCSPVivax-like. E por último, há uma proteína recombinante que não apresenta a porção central, apenas as porções conservadas entre os alelos, N- e C-terminal, chamada de PvCSP-No Repeats.

$\mathrm{Na}$ figura 21B comparamos os títulos de Ac séricos IgG gerados pelos camundongos imunizados com os protocolos de prime-boost homólogo contendo Poly(I:C) + His 6 -PvCSPVK210 + His $_{6}$-PvCSP-VK247 + His 6 -PvCSP-Vivax-like (30 $\mu \mathrm{g} /$ dose/animal). Alternativamente usamos os soros dos animais imunizados com o regime de prime-boost heterólogo AdCh68PvCSP seguido de Poly(I:C) + His ${ }_{6}$-PvCSP-VK210 + His $_{6}$-PvCSP-VK247 + His 6 -PvCSP-Vivaxlike (30 $\mu \mathrm{g} / \mathrm{dose} / \mathrm{animal})$. Os títulos de Ac nos soros dos camundongos foram determinados por ELISA contra cada uma das proteínas representadas na figura 21A. Os resultados nos mostram que ambos os grupos de animais apresentaram Ac para todas as proteínas recombinantes contendo epítopos da PvCSP. Desta forma concluimos que ambos os protcolos de vacinação induzem Ac do tipo IgG contra as diferentes regiões da PvCSP. 
A

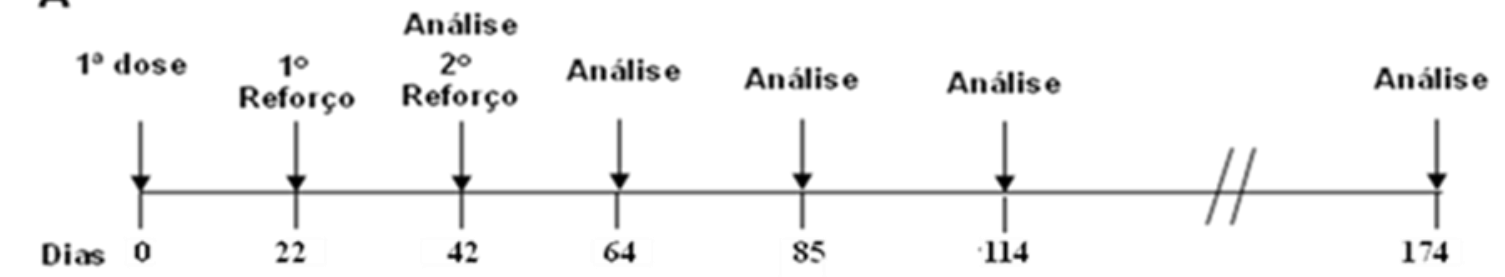

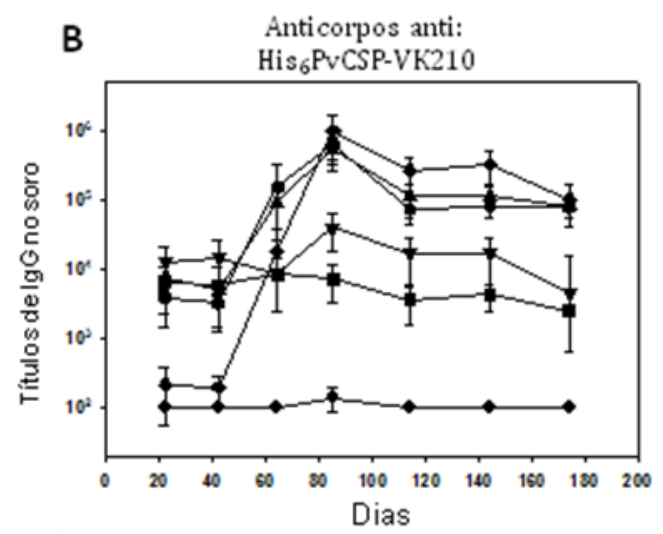

D Anticorpos anti:

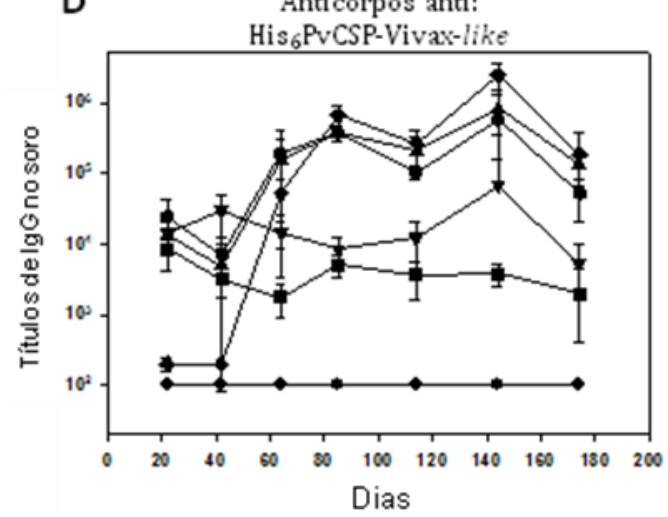

C Anticorpos anti:

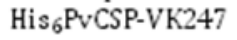

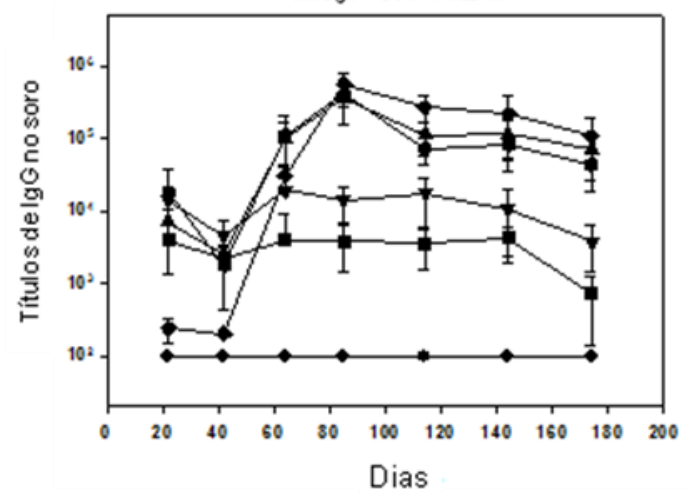

1' dose vacinal (Prime) / Reforço (Boost)

- G1 - AdHu5-ßgal / Poly(I:C)

- G2 - AdCh68-PvCSP I Poly(I:C)

- G3 - AdHu5-PvCSP / Poly(I:C)

- G4 - AdHu5- $\beta$ gal / Poly(I:C) + Mistura de proteinas PvCSP

- G5 - AdCh68-PvCSP / Poly(I:C) + Mistura de proteinas PVCSP

- G6 - AdHu5-PvCSP I Poly(I:C) + Mistura de proteinas PvCSP

Figura 20: Longevidade da resposta de Ac específicos em camundongos imunizados com adenovírus recombinantes expressando PvCSP como parte de um regime de vacinação do tipo prime-boost heterólogo. (A) Camundongos C57BL/6 foram imunizados como descrito na figura anterior. Uma terceira dose foi administrada pela via s.c., com formulação vacinal contendo somente o adjuvante Poly(I:C), ou a mistura das proteínas recombinantes PvCSP, His $6^{-}$ PvCSP-VK210 + His $_{6}-$ PvCSP-VK247 + His $_{6}$-PvCSP-Vivax-like, na presença do Poly(I:C) - 3 $\mu \mathrm{g} /$ dose/camundongo. Os títulos de Ac séricos do tipo IgG foram determinados para (B) His $6^{-}$ 
PvCSP-VK210, ou (C) His 6 -PvCSP-VK247, ou (D) His 6 -PvCSP-Vivax-like. Camundongos que foram imunizados com AdHu5-ßgal ou AdCh68-PvCSP ou AdHu5-PvCSP, e receberam as duas doses reforços com a mistura das CSP na presença do adjuvante (G4, G5 e G6) responderam igualmente (One-Way ANOVA, Tukey HSD, p=NS). Resultados expressos como média \pm S.D. $(n=5)$.

A

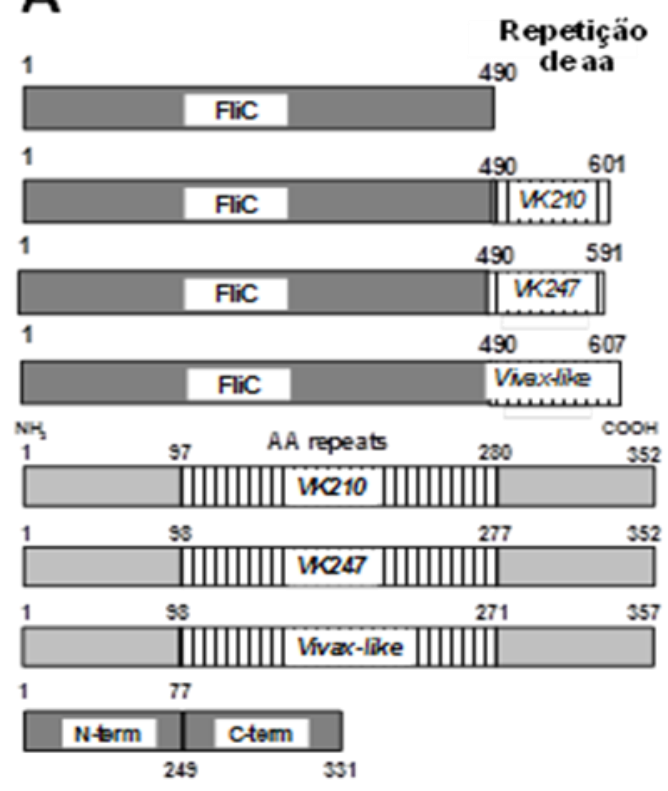

B

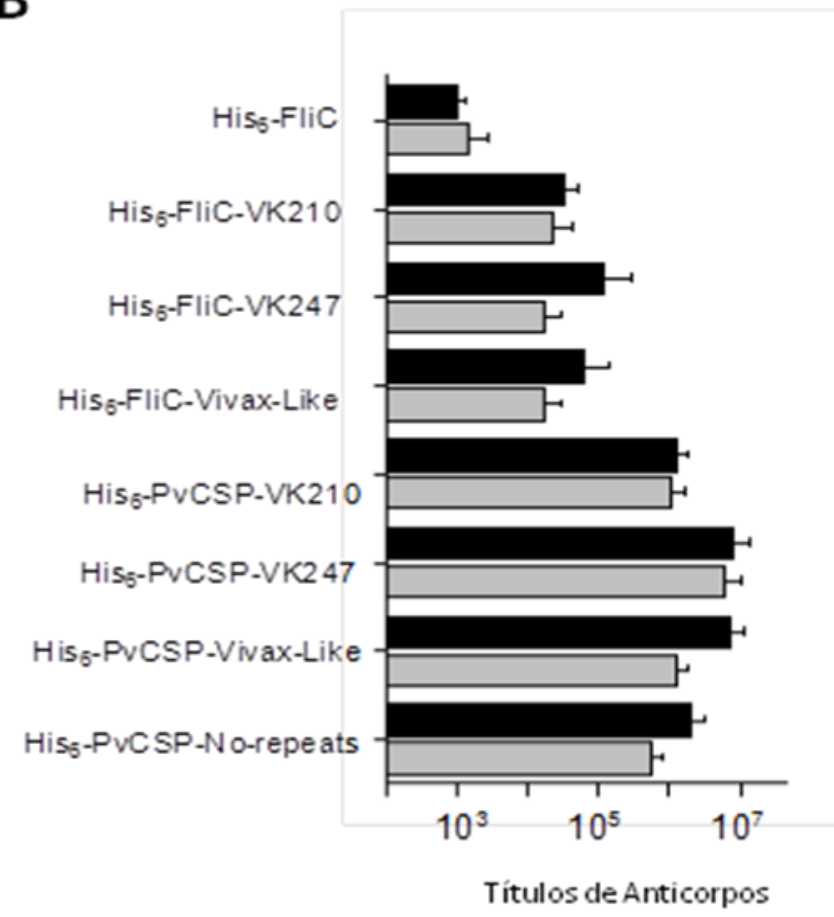

Regime de Prime-boost

Homólogo (proteína/proteína)

Heterólogo (adenovírus/proteína)

Figura 21: Especificidade dos Ac gerados após vacinações experimentais homóloga (proteína-proteína) ou heteróloga (adenovírus-proteína). (A) Representação esquemática de cada proteína recombinante utilizada. (B) Foram utilizados soros de camundongos imunizados em regime de prime-boost homólogo (proteína-proteína) ou heterólogo (adenovírus-proteína) para a determinação da especificidade de Ac IgG anti-PvCSP. (One-Way ANOVA, p=NS) Resultados expressos como média \pm S.D..

Com o intuito de confirmar a presença dos Ac específicos para as regiões repetidas da PvCSP, geramos novas proteínas recombinantes contendo estas regiões em fusão com a proteína 
GST. Na figura 22 estão representadas as proteínas recombinantes contendo os domínios centrais de cada variante alélica.

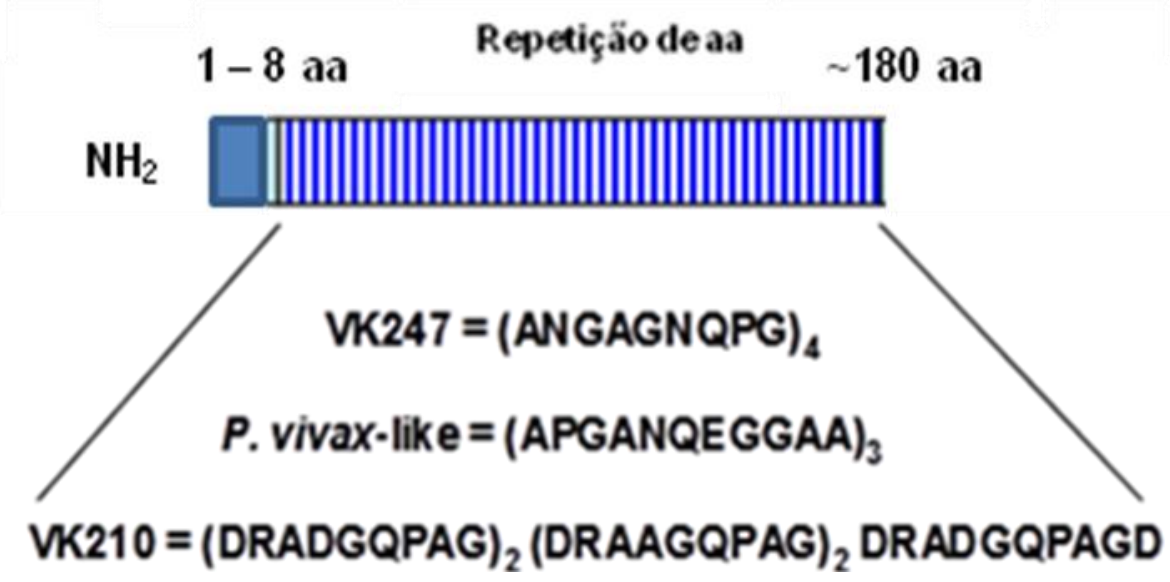

Figura 22: Representação esquemática das proteínas de fusão contendo as seqüências das regiões centrais repetidas de aa presentes em cada forma alélica da PvCSP (VK 210, VK247 e Vivax-like).

Os genes sintéticos com códons otimizados para expressão em E. coli foram introduzidos no vetor de expressão pGEX3X que contém uma sequência que codifica para a proteína Glutationa S-transferase (GST). Desta forma sintetizamos genes que codificam as seguintes proteínas:

\section{1) GST- PvCSP-VK210}

ENKLKQPGDRADGQPAGDRADGQPAGDRADGQPAGDRADGQPAGDRAAGQPAGDRADGQPAGDR ADGQPAGDRADGQPAGDRADGQPAGDRAAGQPAGDRAAGQPAGDRADGQPAGDRAAGQPAGDRA DGQPAGDRAAGQPAGDRADGQPAGDRAAGQPAGDRAAGQPAGDRAAGQAAGD

\section{2) GST- PvCSP-VK247}

ENKLKQPGANGAGNQPGANGAGNQPGANGAGNQPGANGAGNQPGANGAGNQPGANGAGNQPGAN GAGNQPGANGAGNQPGANGAGNQPGAGNQPGANGAGNQPGANGAGNQPGANGAGNQPGANGAGN QPGANGAGNQPGANGAGNQPGANGAGNQPGGN 


\section{3) GST- PvCSP-Vivax-like}

ENKLKQPGAPGANQEGGAAAPGANQEGGAAAPGANQEGGAAAPGANQEGGAAAPGANQEGGAAA PGANQEGGAAAPGANQEGGAAAPGANQEGGAAAPGANQEGGAAAPGANQEGGAAAPGANQEGGA AAPGANQEGGAAAPGANQEGGAAAPGANQEGGAAAPGANQEGGAAAPGANQEG

Para determinarmos a especificidade dos Ac gerados em camundongos C57BL/6 imunizados tanto em regime de imunização homólogo quanto heterólogo, testamos os soros contra três proteínas que apresentam repetições de aa centrais de cada alelo da PvCSP. Os camundongos dos grupos 1 e 2 receberam a primeira dose vacinal (prime), contendo somente o adjuvante Poly(I:C) $(50 \mu \mathrm{g})$, ou uma mistura das proteínas recombinantes PvCSP, $\mathrm{His}_{6}$-PvCSPVK210 + His $_{6}$-PvCSP-VK247 + His 6 -PvCSP-Vivax-like (1 $\left.\mu \mathrm{g} / \mathrm{cada}\right)$, na presença do Poly(I:C), pela via s.c., respectivamente. Os camundongos dos grupos 3, 4, 5 e 6 receberam a primeira dose vacinal (prime) contendo somente adenovírus recombinante AdHu5-ßgal (grupos 3 e 4), ou AdCh68-PvCSP (grupo 5), ou AdHu5-PvCSP (grupo 6), na dose de $2 \mathrm{X}^{7} 0^{7} \mathrm{pfu} / \mathrm{camundongo}$, pela via i.m.. Após 21 e 42 dias, para os grupos 1 e 2, foram administradas doses-reforço (boost) iguais as doses iniciais. Após 42 e 63 dias, para o grupo 3, foi administrada dose-reforço (boost) contendo o adjuvante Poly(I:C) (50 $\mu \mathrm{g})$, e para os grupos 4, 5 e 6 foram administradas dosesreforço (boost) contendo uma mistura das proteínas recombinantes PvCSP, His 6 -PvCSP-VK210 + His ${ }_{6}$-PvCSP-VK247 + His $_{6}$-PvCSP-Vivax-like (1 $\left.\mu \mathrm{g} / \mathrm{cada}\right)$, na presença do Poly(I:C), pela via s.c.. O sangue dos camundongos foi coletado antes de cada uma das 3 doses vacinais e os soros foram analisados por ELISA, três semanas após a terceira dose vacinal. Os soros foram testados contra cada uma das três proteínas recombinantes acima representadas e comparados entre grupos (figura 23).

Pudemos observar que camundongos que foram imunizados somente com o adjuvante, ou com AdHu5- $\beta$ gal ou AdCh68-PvCSP ou AdHu5-PvCSP, e receberam as doses- reforço com a mistura das PvCSP na presença do adjuvante Poly(I:C) (grupos 2, 4, 5 e 6) responderam igualmente sem diferenças estatísticas, em relação a cada uma das proteínas analisadas. Os títulos de Ac específicos gerados pelos camundongos dos grupos 2, 4, 5 e 6 quando testados contra as proteínas GST-PvCSP-VK210 ou GST-PvCSP-VK247, ficaram próximos de $10^{4}$. E quando testados contra a proteína GST-PvCSP-Vivax-like ficaram próximos de $10^{3}$ (figura 23). Desta forma confirmamos que os diferentes regimes de vacinação expeimental induzem Ac do tipo IgG contra as regiões repetidas da PvCSP. Observamos também que os diferentes regimes de vacinação não são distntos nos títulos de Ac induzidos. 


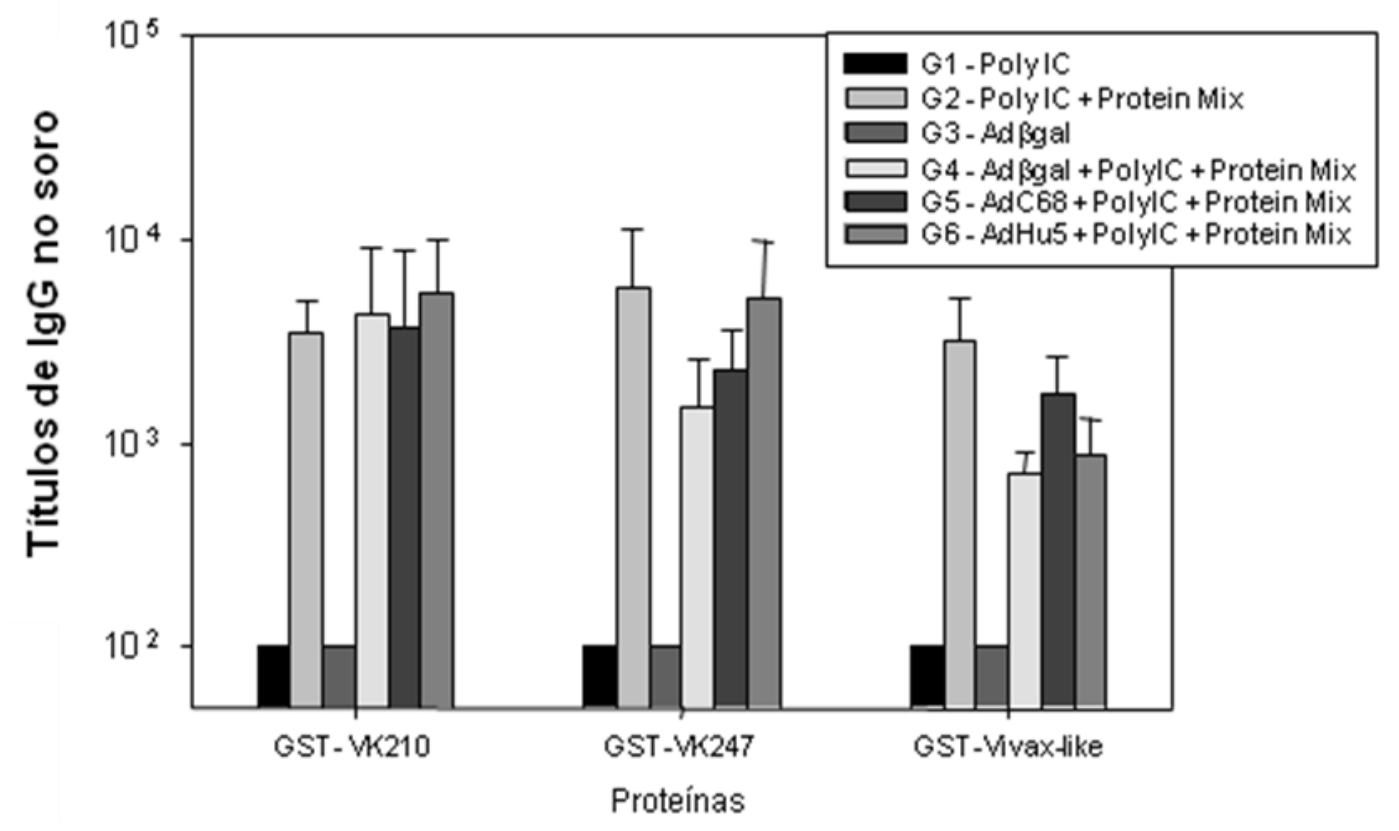

Figura 23: Resposta imune de Ac específicos contra as regiões repetidas da PvCSP em camundongos imunizados segundo os regimes de vacinação homólogo ou heterólogo. Camundongos C57BL/6 receberam a primeira dose vacinal contendo somente o adjuvante Poly(I:C) (50 $\mu \mathrm{g}$ - controle) pela via s.c., ou adenovírus recombinante AdHu5-ßgal (controle), ou AdCh68-PvCSP, ou AdHu5-PvCSP, na dose de 2X107 pfu/camundongo, pela via i.m.. Após receberem 2 doses vacinais como reforço (boost), sendo que os grupos 1 e 3 receberam doses vacinais contendo o adjuvante Poly(I:C) $(50 \mu \mathrm{g})$, e os demais grupos $(2,4,5$ e 6$)$ uma mistura das proteínas recombinantes PvCSP, His 6 -PvCSP-VK210 + His $_{6}$-PvCSP-VK247 + His 6 -PvCSPVivax-like (1 $\mu \mathrm{g} / \mathrm{cada})$, na presença do Poly(I:C), pela via s.c., os soros destes camundongos foram analisados através de Elisa, 3 semanas após a última dose vacinal. Os títulos de Ac séricos do tipo IgG foram determinados contra a GST-PvCSP-VK210, ou GST-PvCSP-VK247, ou GSTPvCSP-Vivax-like. Não houve diferenças signficativas entre os títulos de Ac dos grupos 2, 4, 5 e 6 (One-Way ANOVA, Tukey HSD, p=NS). Resultados expressos como média \pm S.D. $(n=5)$.

A fim de determinar se os Ac gerados pelos diferentes protocolos de vacinação experimental seriam capazes de reconhecer a proteína nativa na superfície de esporozoítas de $P$. vivax das formas variantes da PvCSP, VK210, e VK247, fizemos ensaios de IFI (figura 24 A-D).

$\mathrm{Na}$ figura 24A verificamos que os Ac gerados por camundongos que foram imunizados tanto com o protocolo de prime-boost homólogo (a mistura das três proteínas recombinantes PvCSP na presença de Poly(I:C) ou heterólogo AdCh68-PvCSP mais a mistura das três proteínas 
recombinantes PvCSP, ambas na presença do adjuvante Poly(I:C), foram capazes de reconhecer esporozoítas do $P$. vivax variante VK247. Na figura 24C verificamos que os Ac gerados por camundongos que foram imunizados com a mistura das três proteínas recombinantes PvCSP na presença do adjuvante Poly(I:C), foram capazes de reconhecer esporozoítas do $P$. vivax variante VK210. As figuras 24B e 24D mostram os controles negativos, onde verificamos que soros de camundongos imunizados somente com o adjuvante Poly(I:C), não apresentam Ac contra a proteína PvCSP presente na superfície de esporozoítas do P. vivax.

Através deste ensaio, pudemos determinar que os Ac produzidos são de fato capazes de reconhecer a proteína nativa (figura 24A-D).

Com a finalidade de determinar a qualidade da resposta imune humoral, foram determinados as subclasses de $\operatorname{IgG}$ (IgG1, IgG2b e IgG2c) anti-PvCSP, utilizando os soros dos camundongos que apresentaram maiores títulos de $\mathrm{AC}$ específicos contra as proteínas recombinantes PvCSP (figura 25).

Foram utilizados os soros dos camundongos imunizados com as três proteínas

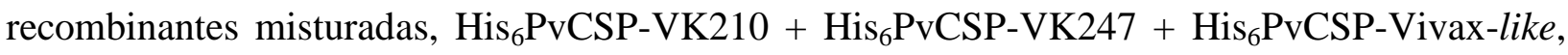
na presença dos adjuvantes CFA/IFA ou Poly(I:C), e os soros dos camundongos que foram imunizados com o AdCh68-PvCSP e receberam os reforços com His ${ }_{6} \mathrm{PvCSP}_{\mathrm{N}} \mathrm{K} 210+$

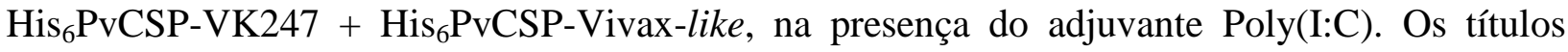
foram determinados pela detecção de Ac contra a proteína $\mathrm{His}_{6} \mathrm{PvCSP}-\mathrm{VK} 210$.

Todos os camundongos imunizados com estas formulações vacinais desenvolveram altos títulos de IgG1, sendo o grupo que recebeu os adjuvantes CFA/IFA apresentou razão IgG1/IgG2c de 19,2, indicando um perfil de resposta com uma tendência Th2. Já os grupos que receberam o AdCh68-PvCSP ou adjuvante Poly(I:C), desenvolveram títulos de IgG2c um pouco mais alto do que IgG1 apresentando razão $\operatorname{IgG1/IgG2c~de~2,5~e~0,95,~respectivamente,~indicando~}$ um perfil de resposta mais balanceada entre Th1 e Th2. Portanto, houve uma diferença significativa nos títulos de Ac do tipo $\operatorname{IgG} 2 \mathrm{c}$ quando foram usados os dois adjuvantes distintos. Assim a reposta imune de Ac induzida na presença de Poly(I:C) apresentou uma predominância de IgG2C sobre IgG1 (figura 25). 


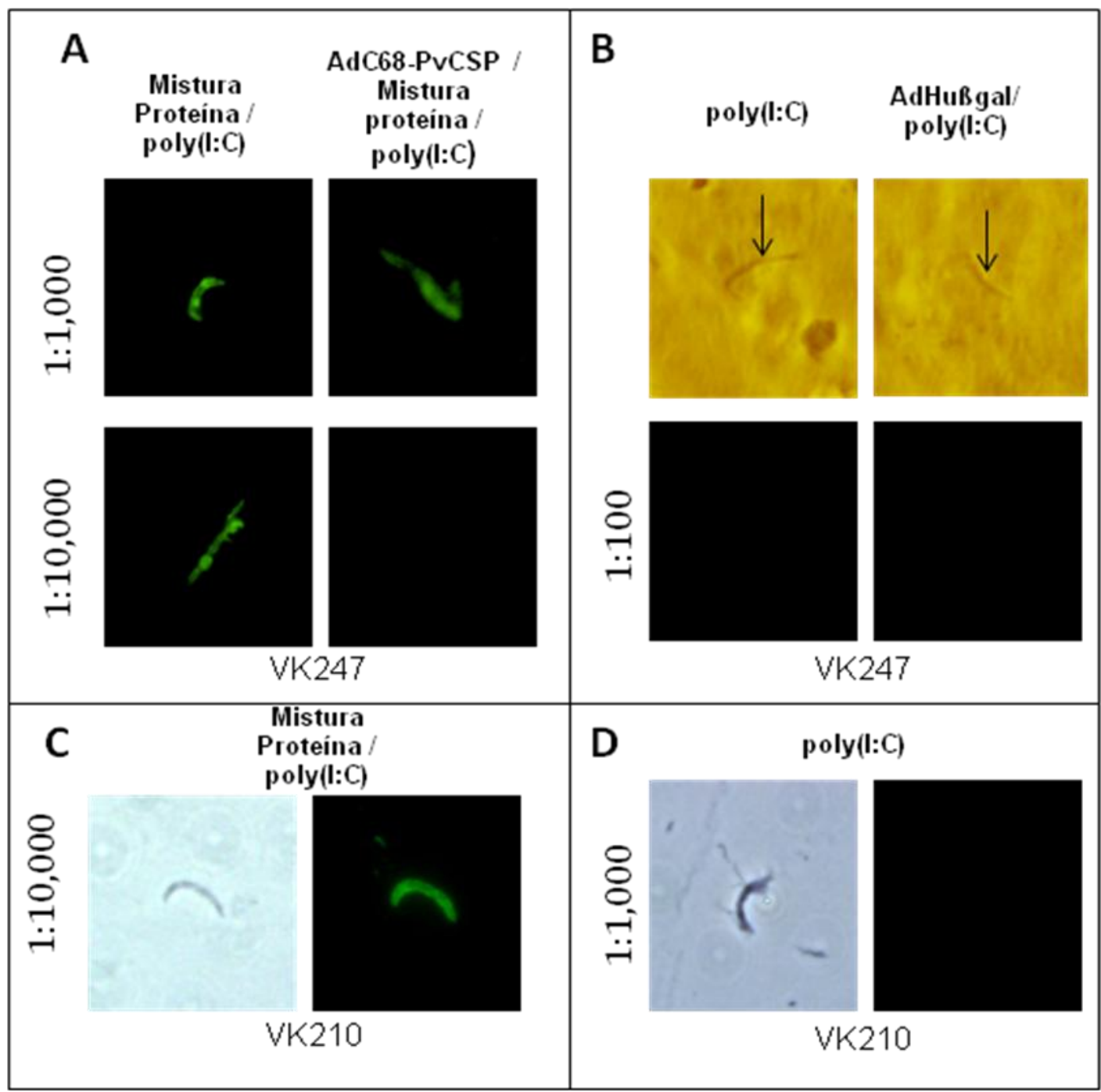

Figura 24: Reconhecimento da PvCSP nativa por Ac de C57BL/6 imunizados com os regimes de prime-boost homólogo ou heterólogo. (A) Ac gerados por camundongos que foram imunizados tanto com Poly(I:C) + His $_{6}$-PvCSP-VK210 + His $_{6}-$ PvCSP-VK247 + His 6 -PvCSPVivax-like (30 $\mu \mathrm{g} / \mathrm{dose} / \mathrm{animal})$, quanto com AdCh68-PvCSP + Poly(I:C) + His 6 -PvCSP-VK210 + His $_{6}$-PvCSP-VK247 + His $_{6}$-PvCSP-Vivax-like (30 $\left.\mu \mathrm{g} / \mathrm{dose} / \mathrm{animal}\right)$ foram capazes de reconhecer esporozoítas do $P$. vivax variante PvCSP-VK247. (B) AC gerados por camundongos que foram imunizados tanto com Poly(I:C) quanto com AdHu5-ßgal + Poly(I:C) não reconheceram esporozoítas nativos da variante PvCSP-VK247 (grupos controles do ensaio). (C) Ac gerados por camundongos que foram imunizados com Poly(I:C) + His 6 -PvCSP-VK210 + His $_{6}$-PvCSP-VK247 + His $_{6}$-PvCSP-Vivax-like $(30 \mu \mathrm{g} /$ dose/animal $)$, foram capazes de reconhecer esporozoítas do P. vivax variante PvCSP-VK210. (D) Ac gerados por camundongos que foram imunizados com Poly(I:C) não reconheceram esporozoítas nativos da variante PvCSPVK210 (grupo controle do ensaio). 
Anticorpos anti: His6 PVCS VK210

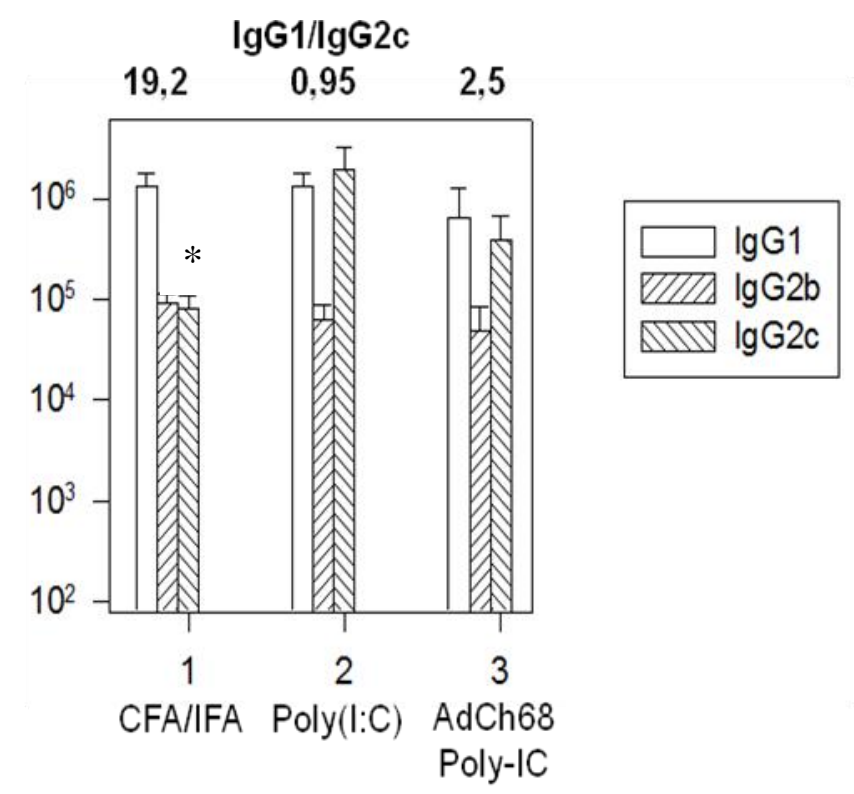

Imunizaçōes

1 - CFA/IFA + His6-PvCS-VK210 + His6-PvCS-VK247 + His6-PvCS-Vivax-like (30ug)

2 - Poly-IC + His6-PvCS-VK210 + His6-PvCS-VK247 + His6-PvCS-Vivax-like (30ug)

3 - AdChPVCS + Poly-IC + His - -PvCS-VK210 + His 6 -PvCS-VK247 + His ${ }_{6}-$ PvCS-Vivax-like (30ug)

Figura 25: Determinação das subclasses de IgG dos Ac específicos nos soros dos animais vacinados com os diferentes protocolos experimentais. Títulos de Ac séricos (IgG) de camundongos C57BL/6 imunizados em sistema de prime-boost homólogo ou heterólogo. Os títulos foram determinados por ELISA contra a proteína His ${ }_{6} \mathrm{PvCS}-\mathrm{VK} 210$. (One-Way ANOVA e TuKey HSD, p<0,01).

\subsection{Indução da resposta imune celular contra a PvCSP após os regimes de vacinação homólogo ou heterólogo}

Após determinarmos que nossas formulações vacinais contendo proteínas recombinantes da PvCSP foram capazes de induzir uma resposta humoral, com altos títulos de AC séricos do tipo IgG, testamos se estas seriam capazes de induzir uma resposta imune mediada por linfócitos T. Para tal, usamos como estímulo as próprias proteínas recombinantes PvCSP, ou peptídeos sintéticos representantes das porções da PvCSP. 
Camundongos C57BL/6 foram imunizados com os protocolos de vacinação homóloga ou heteróloga como descrito na figura 26A. Os animais controles (grupo 1) foram primados, pela via i.m., com $2 \mathrm{X}^{8} 0^{8} \mathrm{pfu}$ de AdHu- $\beta$-gal, por camundongo, e as duas doses subsequentes foram administradas com o adjuvante Poly(I:C); Camundongos do grupo 2 foram primados, pela via i.m., com $2 \mathrm{X}^{8} 0^{8}$ pfu de AdCh68-PvCSP, por camundongo, e as duas doses subsequentes foram administradas com o adjuvante Poly(I:C) + His ${ }_{6}$-PvCSP-VK210 + His ${ }_{6}-\mathrm{PvCSP}-\mathrm{VK} 247+$ His $_{6}{ }^{-}$ PvCSP-Vivax-like (30 $\mu \mathrm{g} /$ dose/camundongo), pela via s.c.; Camundongos do grupo 3 receberam as três doses vacinais iguais, pela via s.c., contendo Poly(I:C) + His $_{6}-\mathrm{PvCSP}-\mathrm{VK} 210+\mathrm{His}_{6}{ }^{-}$ PvCSP-VK247 + His 6 -PvCSP-Vivax-like (30 $\mu \mathrm{g} /$ dose/camundongo). Catorze dias após a última imunização, células esplênicas dos camundongos foram novamente estimuladas in vitro na presença dos peptídos sintéticos demonstrados na figura 26B ou com as proteínas recombinantes. A expressão intracelular das citocinas IFN $\gamma, \mathrm{TNF}-\alpha$ e IL-2, após estímulo in vitro dos linfócitos $\mathrm{T} \mathrm{CD}^{+}$e $\mathrm{T} \mathrm{CD}^{+}$com peptídeos sintéticos individuais representantes da proteína PvCSP, pode ser vista na figura 26C. Observamos que houve um acúmulo das diferentes citocinas somente nos linfócitos ativados com o controle positivo Concanavalina A (ConA) (figura 26C).

Tentamos também detectar a secreção de IFN $\gamma$ nestas culturas com o ensaio de ELISPOT. Como descrito acima, só conseguimos detectar secreção de IFN $\gamma$ no controle positivo do ensaio, cultura de linfócito estimulada com ConA (figura 27). A exceção foi um único peptídeo representando a região repetida da variante alélica Vivax-like que foi capaz de estimular um pequeno número de células a produzirem IFN $\gamma$ (figura 27).

Pudemos concluir destes ensaios, que a indução de linfócitos T efetores nestes regimes de vacinação utilizados é baixa. 
A
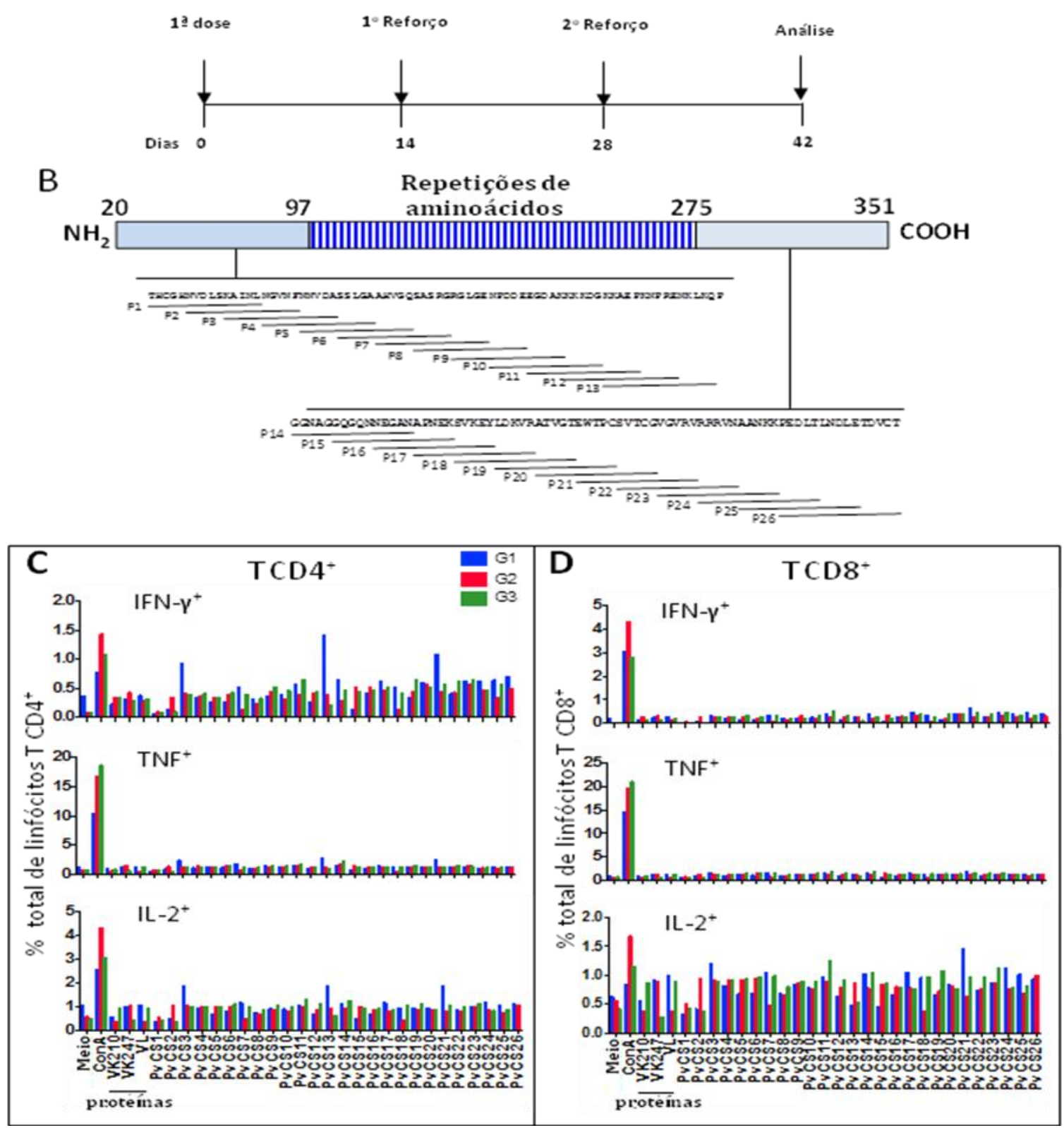

Figura 26: Resposta imune celular após a vacinação com a PvCSP recombinante. (A) Camundongos C57BL/6 foram imunizados com três doses vacinais, a cada 14 dias, e a as análises foram feitas de acordo com o protocolo representado; (B) Representação dos 26 peptídeos sintéticos que se sobrepõe a cada 10 aa, deduzidos das sequências das regiões $\mathrm{N}$ - e Cterminais inteiras, e que foram utilizados para estimular os esplenócitos; (C e D) Camundongos do grupo 1 (controle) foram primados, pela via i.m., com formulação vacinal contendo $2 \times 10^{8}$ pfu de AdHu- $\beta$-gal, por camundongo, e as duas doses subsequentes foram administradas com o adjuvante Poly(I:C); Camundongos do grupo 2 foram primados, pela via i.m., com formulação vacinal contendo $2 \mathrm{X}^{8} 0^{8} \mathrm{pfu}$ de AdCh68-PvCSP, por camundongo, e as duas doses subsequentes 
foram administradas com o adjuvante Poly(I:C) + His 6 -PvCSP-VK210 + His 6 -PvCSP-VK247 + His $_{6}$-PvCSP-Vivax-like (30 $\mu \mathrm{g} /$ dose/camundongo), pela via s.c.; Camundongos do grupo 3 receberam as três doses vacinais iguais, pela via s.c., contendo Poly(I:C) + His 6 -PvCSP-VK210 + His ${ }_{6}$-PvCSP-VK247 + His ${ }_{6}$-PvCSP-Vivax-like (30 $\mu \mathrm{g} /$ dose/camundongo). Catorze dias após a última imunização, células esplênicas dos camundongos, na presença de anti-CD28, monensina e brefeldina-A, foram estimuladas ou não in vitro, com peptídeos sintéticos ou com proteínas recombinantes representantes da PvCSP, ou ConA (controle positivo). Após $12 \mathrm{~h}$ de incubação, as células foram marcadas com anti-CD4, anti-CD8, anti-IL-2, anti-IFN $\gamma$ e anti-TNF- $\alpha$. Resultados foram expressos através da frequencia (\%) dos linfócitos $\mathrm{TCD}^{+}$ou $\mathrm{TCD}^{+}$marcados para cada uma destas citocinas. O resultado é proveniente de pools de células dos animais por grupo.

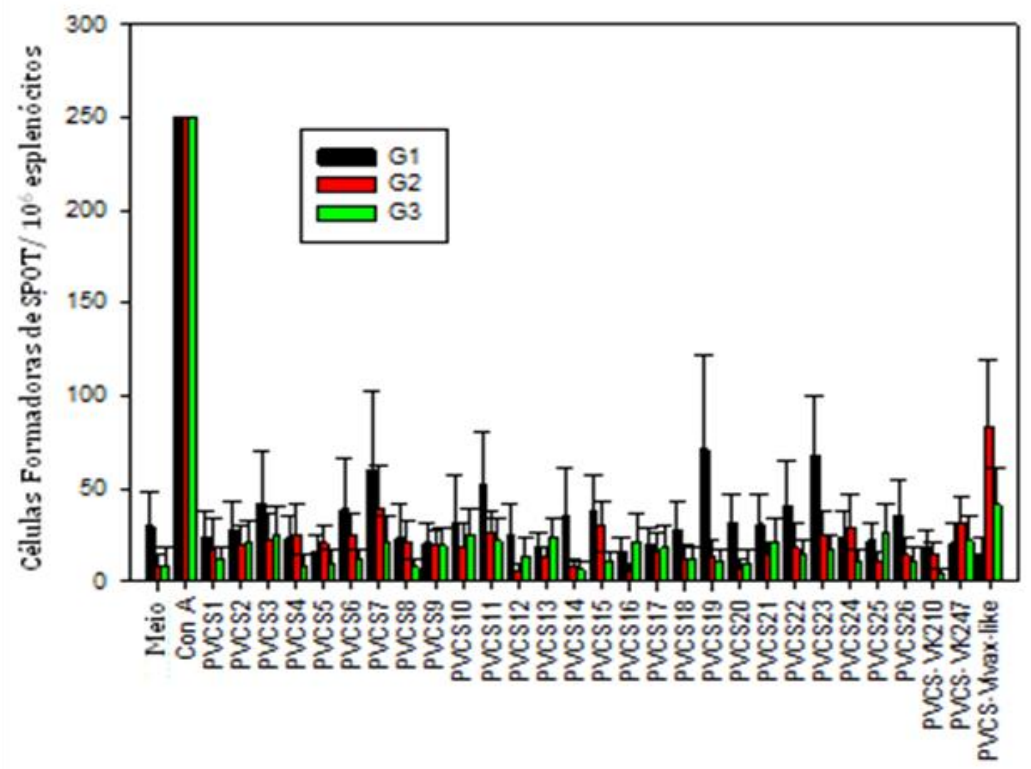

Figura 27: Resposta imune celular após a vacinação com a PvCSP recombinante. Camundongos C57BL/6 foram imunizados como descrito na figura 26. Catorze dias após a última imunização, o baço dos camundongos foram acessados e, foram feitas culturas de esplenócitos estimulados ou não, ex vivo, com peptídeos sintéticos representando a PvCSP inteira ou com ConA (controle positivo), por 48h. Foram contados os número de células formadoras de "spots" (CFS) por $10^{6}$ esplenócitos, representando a produção de IFN $\gamma$ pós estímulos. Resultados foram expressos através da frequência destas células (CFS) obtidas através do pool de células de 5 camundongos por grupo. 
5 DISCUSSÃO 
No presente estudo, testamos se proteínas recombinantes e vetores adenovirais poderiam ser usados para o desenvolvimento de uma vacina universal baseada na CSP contra a malária causada pelo $P$. vivax. Usando protocolos de vacinação homólogos ou heterólogos, fomos capazes de demonstrar com sucesso, que os camundongos isogênicos imunizados com nossas formulações vacinais, foram capazes de gerar altos títulos de Ac reconhecendo as três formas alélicas da CSP de P. vivax. Estas vacinas foram formuladas tanto com a combinação das três proteínas recombinantes representando cada forma alélica da CSP, His 6 -PvCSP-VK210, His $_{6}{ }^{-}$ PvCSP-VK247 e His 6 -PvCSP-Vivax-like, quanto com uma única proteína recombinante contendo os epítopos das três diferentes formas alélicas da CSP fusionados num mesmo polipeptídeo, $\mathrm{His}_{6}$-PvCSP-All-CS-epitopes.

A via de imunização, com as formulações vacinais contendo proteínas recombinantes utilizada por nós foi a via parenteral subcutânea na ausência ou na presença de formulações adjuvantes CFA/IFA ou Poly(I:C). O adjuvante Poly(I:C), um RNA de dupla fita sintético chamado de ácido poliinosínico:policitidílico, é agonista de TLR-3. Este adjuvante foi escolhido para ser usado nas nossas formulações vacinais, pois recentemente foi relatado o uso de Poly(ICLC) injetado subcutaneamente em voluntários humanos induzindo resposta imune inata, desencadeando muitas vias que imitam os resultados obtidos em estudos realizados com a vacina contendo o vírus vivo atenuado causador da febre amarela YF17D (Caskey et al., 2011). Trabalho recentemente publicado usando a CSP de P. falciparum como candidata vacinal, desenvolveu formulações capazes de induzir potente resposta imune humoral, celular e protetora utilizando como adjuvante o Poly(ICLC). As proteínas que foram expressas em sistema bacteriano (E. coli) induziram respostas com altos títulos de Ac contra a região central contendo repetição de aminoácidos (NANP) e induziram potentes respostas específicas mediadas por células T CD4 ${ }^{+}$efetoras multifuncionais, presentes no sangue, no baço e no fígado (Kastenmuller et al., 2012). O desafio dos camundongos imunizados foi feito com parasitos transgênicos $P$. berghei expressando a CSP de P. falciparum ( $P b$-CS $(P f)$ ). Houve cerca de $50 \%$ de proteção esterilizante que foi correlacionada com altos títulos de Ac séricos, mas não com a resposta mediada por células $\mathrm{T} \mathrm{CD}^{+}$. Através destes resultados pode ser concluído que o uso deste potente adjuvante, em formulações vacinais, pode contribuir para a prevenção da infecção malárica (Kastenmuller et al., 2012).

Observamos que a resposta imune medida pela concentração de Ac séricos após três doses de antígenos presentes na formulação vacinal contendo Poly(I:C) foi comparável aos adjuvantes CFA/IFA, considerados como o padrão ouro da imunologia. Esta semelhança se deu nos títulos de Ac e na longevidade destes. Entretanto, na presença do adjuvante Poly(I:C), 
achamos que a mistura das proteínas foi um pouco mais imunogênica. Este aumento da imunogenicidade não foi observado quando estes antígenos foram emulsionados com os adjuvantes CFA/IFA nas formulações vacinais. A razão precisa para estas diferenças encontradas não está clara. Com tudo, estes dados mostram a importância de se testar diferentes formulações vacinais para que possamos selecionar a melhor vacina.

Adicionalmente, testamos formulações vacinais na qual a CSP foi expressa a partir de vetores adenovirais Ch68 ou Hu5 ambos deficientes em replicação. Estes vetores expressam a proteína híbrida $\mathrm{His}_{6}$-PvCSP-All-CS-epitopes. Estas formulações foram utilizadas em sistema de prime-boost heterólogo. Utilizando tanto protocolos de imunização homóloga (proteína/proteína) quanto heteróloga (vetor adenviral/proteína), os camundongos imunizados foram capazes de gerar títulos de Ac específicos tão altos quanto os títulos de Ac observados nas imunizações com formulações vacinais contendo as proteínas recombinantes emulsificadas nos adjuvantes CFA/IFA. Em adição, a resposta induzida por estes Ac em ambos os protocolos vacinais, foi de longa duração, pois títulos significativos foram observados durante todo o período do estudo de aproximadamente 180 dias.

Nós focamos nossos esforços na indução persistente destes altos títulos de Ac específicos contra a CSP. Ac contra este antígeno vêm sendo descritos como um mecanismo capaz de vacinar contra a malária em diversos modelos experimentais assim como em seres humanos (Cohen et al., 2010). Tomando como base um ensaio clínico humano de fase II onde utilizam a vacina RTS,S/AS, a concentração de Ac é correlacionada fortemente com a imunidade estéril (prevenção da doença). Em indivíduos que receberam esta vacina, e que foram experimentalmente desafiados com esporozoítas de $P$. falciparum através da picada de mosquitos infectados, a eficácia da vacina foi correlacionada com altos títulos de Ac contra a CSP e esporozoítas (Kester et al., 2009). Similarmente, outro estudo clínico de fase II realizado com crianças africanas não demonstrou uma relação linear entre títulos de Ac contra a CSP e baixa incidência de malária (Olotu et al., 2011).

Há muito tempo que é conhecida a capacidade de Ac contra as regiões repetidas da CSP de diversas espécies de esporozoítas em inibir a infecção experimental (Yoshida et al., 1980). Diversos mecanismos anti-parasitários são descritos mediados por Ac contra a CSP. Estes Ac são capazes de reduzir o número de esporozoítas no sítio do inóculo e a viabilidade dos parasitos durante a picada do mosquito. Através de um modelo murino experimental, foi demonstrado um imunocomplexo formado durante a picada do mosquito que reduziu o número de esporozoítas depositados na derme durante o repasto sanguíneo (Kebaier et al., 2009). Os parasitos injetados em camundongos imunes foram imobilizados e não foram capazes de invadir os vasos 
sanguíneos na derme (Kebaier et al., 2009). Quando esporozoítas foram inoculados intravenosamente, ou seja, não precisando ultrapassar a barreira da pele, Ac anti-CSP bloquearam eficientemente a infecção dos hepatócitos (Kebaier et al., 2009). A inibição da infecção de hepatócitos pode também estar relacionada com a redução da habilidade da migração e do ataque dos esporozoítas aos hepatócitos (Coppi et al., 2011; Lacroix, Menard, 2008; Montagna et al., 2012). Recentemente, outro estudo tentou demonstrar o possível efeito de Ac anti-CSP sobre a capacidade de esporozoítas atravessarem as células, pois a motilidade dos esporozoítas pode ser medida indiretamente através da secreção de CSP durante o movimento de migração. Uso de um anticorpo monoclonal anti-CSP foi capaz de inibir a travessia de esporozoítas por células, portanto eles acreditam que Ac induzidos através de vacinas contendo a CSP podem inibir a migração de esporozoítas, no estágio inicial da infecção, da pele até o fígado (Mishra et al., 2012).

No caso do $P$. vivax, um estudo recente confirmou a especificidade de Ac inibitórios contra a região central repetida da CSP através do uso de esporozoítas transgênicos de $P$. berghei expressando o domínio de repetição central da cepa VK210. A infectividade deste parasito foi drasticamente inibida em camundongos sendo demonstrada in vivo, através de transferência passiva de Ac monoclonal anti-VK210 (Espinosa et al., 2013). Estas observações confirmaram dados similares obtidos a partir de outros parasitas demonstrando que o domínio de repetição central da CSP é um alvo importante para neutralizar a infectividade dos esporozoítas.

Em adição ao domínio central de repetição de aminoácidos, no caso da CSP de $P$. vivax, humanos que foram imunizados com formulações vacinais contendo longos peptídeos sintéticos representando as porções $\mathrm{N}$ e $\mathrm{C}$ terminais da CSP, geraram Ac que puderam inibir a invasão de esporozoítas in vitro (Arevalo-Herrera et al., 2011). Estes resultados indicam que vacinas que induzem altos títulos de Ac contra as diferentes regiões da CSP podem ser úteis para o desenvolvimento de uma vacina eficaz.

Nos protocolos de vacinação descritos nesta tese, fomos capazes de induzir a geração de altos títulos de Ac contra as três diferentes formas alélicas da CSP que reagem contra os diferentes domínios da proteína. Análises usando esporozoítas das cepas VK210 e VK247 de $P$. vivax, demonstraram que estas formulações vacinais induziram Ac que foram capazes de reconhecer também a CSP nativa de esporozoítas detectados através do ensaio de imunofluorescência indireta. Entretanto a habilidade para estes Ac neutralizarem esporozoítas in vivo deve ser ainda avaliada utilizando parasitas transgênicos que expressem a CSP de $P$. vivax (Espinosa et al., 2013). 
A classificação das subclasses de IgG encontradas nos soros de camundongos imunizados é útil para a avaliação e qualificação da resposta imune humoral nas vacinas e nas infecções. Em particular, as respostas predominantes relativas aos Ac IgG1 e IgE contra as respostas relativas aos Ac IgG2a (razão IgG1/IgG2) acredita-se estarem relacionadas com a estimulação das células Th2 e estas auxiliarem na estimulação das células Th1 (Gupta, Siber, 1995).

Portanto, acessamos a qualidade da resposta imune humoral através da determinação das subclasses de IgG e, esta se mostrou distinta. Pudemos observar que os camundongos imunizados com todas as formulações vacinais testadas por nós desenvolveram altos títulos de IgG1. Entretanto, grupos de camundongos que receberam doses vacinais contendo o adjuvante Poly(I:C) bem como grupos de camundongos imunizados com o vetor adenoviral recombinante, apresentaram predominância da subclasse $\operatorname{IgG} 2$ c sobre a subclasse $\operatorname{IgG} 1$, indicando um perfil de resposta mais para Th1. Esta predominância da subclasse IgG1 já havia sido observada em estudos anteriores realizados por nosso grupo, através da análise dos soros dos camundongos que foram imunizados com formulações vacinais contendo as PvCSP recombinantes fusionadas a Flic (flagelina de Salmonella thiphymurium) na porção N-terminal, His ${ }_{6}$-FliC-PvCSP-VK210, His $_{6}$-FliC-PvCSP-VK247, His 6 -FliC-PvCSP-Vivax-like e His ${ }_{6}$-FliC-PvCSP-All-CS-epitopes (Camacho et al., 2011; Camacho 2012; Leal et al., 2013).

Em adição aos Ac, células $\mathrm{T} \mathrm{CD}^{+}$e $\mathrm{CD}^{+}$vêm sendo descritas como potenciais mediadoras da eliminação do estágio pré-eritrocítico em modelos murinos de experimentação (Nardin, Nussenzweig, 1993; Arevalo-Herrera et al., 2011; Douradinha, Doolan, 2011; Schwenk, Richie, 2011; Sinnis, Zavala, 2012; Soares et al., 2012; Vaughan, Kappe, 2012). A produção de IFN- $\gamma$ tanto por células $\mathrm{T} \mathrm{CD}^{+}$quanto por células $\mathrm{T} \mathrm{CD} 8^{+}$é considerada o mecanismo mais importante envolvido na imunidade protetora do estágio pré-eritrocítico (Arevalo-Herrera et al., 2011). De fato, inúmeros epítopos para células T já foram descritos na CSP (Arevalo-Herrera et al., 2011; Douradinha, Doolan, 2011; Nardin, Nussenzweig, 1993; Schwenk, Richie, 2011; Sinnis, Zavala, 2012; Soares et al., 2012; Vaughan, Kappe, 2012). Os resultados nos modelos murinos estimularam ensaios clínicos usando DNA plasmidial, vírus recombinante e, mais recentemente, formulações vacinais contendo esporozoítas atenuados por radiação. Entretanto, apesar do entusiasmo gerado através destes modelos murinos, vacinas baseadas em células T contra estágios pré-eritrocíticos têm apenas fornecido imunidade estéril contra infecções causadas pelo P. falciparum em alguns indivíduos vacinados (Chuang et al., 2013; Ewer et al., 2013).

A razão precisa para estes resultados tão pobres não está clara. Apesar das células $\mathrm{T}$ estarem presentes e circularem no fígado humano, talvez a frequência destas células $\mathrm{T}$ geradas 
através dos diferentes protocolos vacinais tenha sido baixa, não apresentando número suficiente para serem capazes de vasculhar todo o fígado. Na verdade, desde que os primeiros resultados de transferência adotiva de células $\mathrm{T}$ foram mostrados há mais de 20 anos atrás, tem-se o conhecimento de que um grande número de células efetoras $\mathrm{T} \mathrm{CD} 8^{+}$necessitam ser transferidas para camundongos a fim de proporcionar imunidade estéril ( Rodrigues et al., 1991; Rodrigues et al., 1992; Romero et al., 1989). Mais recentemente, um estudo elegante utilizando modelo murino confirmou que um grande número de células efetoras $\mathrm{T} \mathrm{CD} 8^{+}$multifuncionais devem ser geradas para proporcionar proteção estéril (Schmidt et al., 2008).

Ensaios pré-clínicos de imunização utilizando modelos animais, como camundongos e primatas não humanos, têm sido realizados nos últimos anos, com a finalidade do desenvolvimento de uma vacina, utilizando candidatos vacinais contra estágios pré-eritrocíticos de $P$. vivax (Lumsden et al., 2011; Moon et al., 2012; Yadava et al., 2007). Um único ensaio clínico de fase I foi publicado usando formulações vacinais contendo peptídeos sintéticos longos baseados na CSP de P. vivax na presença do adjuvante Montanide (Corradin et al., 2012).

Apesar das nossas formulações vacinais induzirem altos títulos de Ac, gerado pelos camundongos imunizados com formulações vacinais contendo a proteína PvCSP, ao realizarmos diversos ensaios para acessar a resposta imune celular mediada por células $\mathrm{T}$ produtoras de citocinas, como IFN- $\gamma$, TNF- $\alpha$ e IL-2, após estímulo com antígenos provenientes da PvCSP, como ensaios de ELISPOT e de Marcação intracelular (ICS) de linfócitos provenientes do baço de camundongos imunizados, não obtivemos resultados positivos.

Os reagentes e protocolos que descrevemos neste presente estudo, quando utilizamos regimes de imunização homólogos ou heterólogos, podem ser transferidos para ensaios clínicos humanos, uma vez que o adjuvante Poly(ICLC) atualmente está sendo testado para uso em humano (Caskey et al., 2011; Kastenmuller et al., 2012; Park et al., 2013). Similarmente, adenovírus recombinantes humanos do tipo 5 deficientes em replicação estão sendo usados em vários ensaios clínicos humanos (Casazza et al., 2013; De Rosa et al., 2011; Frahm et al., 2012; McElrath et al., 2008), e podem ser promissores para a geração de imunogenicidade de novas formulações vacinais através da indução de respostas humorais e celulares.

As formulações descritas aqui fornecem novos candidatos vacinais contra o $P$. vivax com cobertura universal que justificam ensaios clínicos. 
6 CONCLUSÃO 
Os resultados apresentados nesta tese corroboram com a hipótese de que é possível produzir formulações vacinais baseadas na CSP que induzam imunidade contra as três formas alélicas deste antígeno do parasita e que podem servir como base para o desenvolvimento de uma vacina universal contra a malária causada pelo $P$. vivax. 


\section{REFERÊNCIAS}


Abdulla S, Oberholzer R, Juma O, Kubhoja S, Machera F, Membi C, et al. Safety and immunogenicity of rts,s/as02d malaria vaccine in infants. N Engl J Med. 2008;359(24):253344.

Agnandji ST, Lell B, Fernandes JF, Abossolo BP, Methogo BG, Kabwende AL, et al. A phase 3 trial of rts,s/as01 malaria vaccine in african infants. N Engl J Med. 2012;367(24):2284-95.

Agnandji ST, Lell B, Soulanoudjingar SS, Fernandes JF, Abossolo BP, Conzelmann C, et al. First results of phase 3 trial of rts,s/as01 malaria vaccine in african children. $\mathrm{N}$ Engl J Med. 2011;365(20):1863-75.

Amino R, Thiberge S, Shorte S, Frischknecht F, Menard R. Quantitative imaging of plasmodium sporozoites in the mammalian host. C R Biol. 2006;329(11):858-62.

Anstey NM, Handojo T, Pain MC, Kenangalem E, Tjitra E, Price RN, et al. Lung injury in vivax malaria: Pathophysiological evidence for pulmonary vascular sequestration and posttreatment alveolar-capillary inflammation. J Infect Dis. 2007;195(4):589-96.

Antinori S, Galimberti L, Milazzo L, Corbellino M. Biology of human malaria plasmodia including plasmodium knowlesi. Mediterr J Hematol Infect Dis. 2012;4(1):e2012013.

Arevalo-Herrera M, Solarte Y, Marin C, Santos M, Castellanos J, Beier JC, et al. Malaria transmission blocking immunity and sexual stage vaccines for interrupting malaria transmission in latin america. Mem Inst Oswaldo Cruz. 2011;106 Suppl 1:202-11.

Autino B, Corbett Y, Castelli F, Taramelli D. Pathogenesis of malaria in tissues and blood. Mediterr J Hematol Infect Dis. 2012;4(1):e2012061.

Bargieri DY, Rosa DS, Braga CJ, Carvalho BO, Costa FT, Espindola NM, et al. New malaria vaccine candidates based on the plasmodium vivax merozoite surface protein-1 and the tlr-5 agonist salmonella typhimurium flic flagellin. Vaccine. 2008;26(48):6132-42.

Bargieri, D.Y. Seleção e desenvolvimento de adjuvantes para uso em imunizações com proteínas recombinantes de Plasmodium. [tese (Doutorado em Ciências)]. São Paulo: Escola Paulista de Medicina, Universidade Federal de São Paulo, UNIFESP; 2009.

Bargieri DY, Soares IS, Costa FT, Braga CJ, Ferreira LC, Rodrigues MM. Malaria vaccine development: Are bacterial flagellin fusion proteins the bridge between mouse and humans? J Parasitol Res. 2011;2011:965369.

Bejon P, Lusingu J, Olotu A, Leach A, Lievens M, Vekemans J, et al. Efficacy of rts,s/as01e vaccine against malaria in children 5 to 17 months of age. N Engl J Med. 2008;359(24):252132.

\footnotetext{
${ }^{1}$ De acordo com: International Committee of Medical Journal Editors. [Internet]. Uniform requirements for manuscripts submitted to Biomedical Journal: sample references. [updated $2011 \mathrm{Jul} 15]$. Available from: http://www.icmje.org.
} 
Bell BA, Wood JF, Bansal R, Ragab H, Cargo J, 3rd, Washington MA, et al. Process development for the production of an e. Coli produced clinical grade recombinant malaria vaccine for plasmodium vivax. Vaccine. 2009;27(9):1448-53.

Bruna-Romero O, Gonzalez-Aseguinolaza G, Hafalla JC, Tsuji M, Nussenzweig RS. Complete, long-lasting protection against malaria of mice primed and boosted with two distinct viral vectors expressing the same plasmodial antigen. Proc Natl Acad Sci U S A. 2001;98(20):11491-6.

Butler NS, Schmidt NW, Vaughan AM, Aly AS, Kappe SH, Harty JT. Superior antimalarial immunity after vaccination with late liver stage-arresting genetically attenuated parasites. Cell Host Microbe. 2011;9(6):451-62.

Camacho, A.G.A. Ativação de TLR5/MyD88 é importante para a imunogenicidade de proteínas de fusão recombinantes contendo epítopos imunodominantes da proteína do circumsporozoíta de Plasmodium vivax e a flagelina FliC de Salmonella enterica Typhimurium. [dissertação (Mestrado em Ciências)]. São Paulo: Escola Paulista de Medicina, Universidade Federal de São Paulo, UNIFESP; 2012.

Camacho AG, Teixeira LH, Bargieri DY, Boscardin SB, Soares IS, Nussenzweig RS, et al. Tlr5-dependent immunogenicity of a recombinant fusion protein containing an immunodominant epitope of malarial circumsporozoite protein and the flic flagellin of salmonella typhimurium. Mem Inst Oswaldo Cruz. 2011;106 Suppl 1:167-71.

Carvalho BO, Lopes SC, Nogueira PA, Orlandi PP, Bargieri DY, Blanco YC, et al. On the cytoadhesion of plasmodium vivax-infected erythrocytes. J Infect Dis. 2010;202(4):638-47.

Casazza JP, Bowman KA, Adzaku S, Smith EC, Enama ME, Bailer RT, et al. Therapeutic vaccination expands and improves the function of the hiv-specific memory t-cell repertoire. $\mathrm{J}$ Infect Dis. 2013;207(12):1829-40.

Caskey M, Lefebvre F, Filali-Mouhim A, Cameron MJ, Goulet JP, Haddad EK, et al. Synthetic double-stranded rna induces innate immune responses similar to a live viral vaccine in humans. J Exp Med. 2011;208(12):2357-66.

Cavasini CE, de Mattos LC, Couto AA, Couto VS, Gollino Y, Moretti LJ, et al. Duffy blood group gene polymorphisms among malaria vivax patients in four areas of the brazilian amazon region. Malar J. 2007;6:167.

Chehuan YF, Costa MR, Costa JS, Alecrim MG, Nogueira F, Silveira H, et al. In vitro chloroquine resistance for plasmodium vivax isolates from the western brazilian amazon. Malar J. 2013;12:226.

Chenet SM, Tapia LL, Escalante AA, Durand S, Lucas C, Bacon DJ. Genetic diversity and population structure of genes encoding vaccine candidate antigens of plasmodium vivax. Malar J. 2012;11:68.

Chuang I, Sedegah M, Cicatelli S, Spring M, Polhemus M, Tamminga C, et al. DNA prime/adenovirus boost malaria vaccine encoding p. Falciparum csp and ama1 induces sterile protection associated with cell-mediated immunity. PLoS One. 2013;8(2):e55571. 
Cohen J, Benns S, Vekemans J, Leach A. [the malaria vaccine candidate rts,s/as is in phase iii clinical trials]. Ann Pharm Fr. 2010;68(6):370-9.

Collins WE, Barnwell JW. A hopeful beginning for malaria vaccines. N Engl J Med. 2008;359(24):2599-601.

Collins WE, Contacos PG. Immunization of monkeys against plasmodium cynomolgi by $\mathrm{x}$ irradiated sporozoites. Nat New Biol. 1972;236(67):176-7.

Collins WE, Jeffery GM, Roberts JM. A retrospective examination of anemia during infection of humans with plasmodium vivax. Am J Trop Med Hyg. 2003;68(4):410-2.

Coppi A, Natarajan R, Pradel G, Bennett BL, James ER, Roggero MA, et al. The malaria circumsporozoite protein has two functional domains, each with distinct roles as sporozoites journey from mosquito to mammalian host. J Exp Med. 2011;208(2):341-56.

Corradin G, Cespedes N, Verdini A, Kajava AV, Arevalo-Herrera M, Herrera S. Malaria vaccine development using synthetic peptides as a technical platform. Adv Immunol. 2012;114:107-49.

Cunha MG, Rodrigues MM, Soares IS. Comparison of the immunogenic properties of recombinant proteins representing the plasmodium vivax vaccine candidate msp1(19) expressed in distinct bacterial vectors. Vaccine. 2001;20(3-4):385-96.

De Rosa SC, Thomas EP, Bui J, Huang Y, deCamp A, Morgan C, et al. Hiv-DNA priming alters $\mathrm{t}$ cell responses to hiv-adenovirus vaccine even when responses to DNA are undetectable. J Immunol. 2011;187(6):3391-401.

Doolan DL, Hoffman SL. Pre-erythrocytic-stage immune effector mechanisms in plasmodium spp. Infections. Philos Trans R Soc Lond B Biol Sci. 1997;352(1359):1361-7.

Douradinha B, Doolan DL. Harnessing immune responses against plasmodium for rational vaccine design. Trends Parasitol. 2011;27(6):274-83.

Epstein JE, Rao S, Williams F, Freilich D, Luke T, Sedegah M, et al. Safety and clinical outcome of experimental challenge of human volunteers with plasmodium falciparuminfected mosquitoes: An update. J Infect Dis. 2007;196(1):145-54.

Epstein JE, Tewari K, Lyke KE, Sim BK, Billingsley PF, Laurens MB, et al. Live attenuated malaria vaccine designed to protect through hepatic cd8(+) t cell immunity. Science. 2011;334(6055):475-80.

Espinosa DA, Yadava A, Angov E, Maurizio PL, Ockenhouse CF, Zavala F. Development of a chimeric plasmodium berghei strain expressing the repeat region of the p. Vivax circumsporozoite protein for in vivo evaluation of vaccine efficacy. Infect Immun. 2013;81(8):2882-7.

Ewer KJ, O'Hara GA, Duncan CJ, Collins KA, Sheehy SH, Reyes-Sandoval A, et al. Protective cd8(+) t-cell immunity to human malaria induced by chimpanzee adenovirus-mva immunisation. Nat Commun. 2013;4:2836. 
Frahm N, DeCamp AC, Friedrich DP, Carter DK, Defawe OD, Kublin JG, et al. Human adenovirus-specific t cells modulate hiv-specific t cell responses to an ad5-vectored hiv-1 vaccine. J Clin Invest. 2012;122(1):359-67.

Foquet L, Hermsen CC, van Gemert GJ, Van Braeckel E, Weening KE, Sauerwein R, et al. Vaccine-induced monoclonal antibodies targeting circumsporozoite protein prevent Plasmodium falciparum infection. J Clin Invest. 2013 Dec 2.

Friesen J, Matuschewski K. Comparative efficacy of pre-erythrocytic whole organism vaccine strategies against the malaria parasite. Vaccine. 2011;29(40):7002-8.

Gething PW, Elyazar IR, Moyes CL, Smith DL, Battle KE, Guerra CA, et al. A long neglected world malaria map: Plasmodium vivax endemicity in 2010. PLoS Negl Trop Dis. 2012;6(9):e1814.

Good MF, Doolan DL. Malaria vaccine design: Immunological considerations. Immunity. 2010;33(4):555-66.

Gordon DM, Cosgriff TM, Schneider I, Wasserman GF, Majarian WR, Hollingdale MR, et al. Safety and immunogenicity of a plasmodium vivax sporozoite vaccine. Am J Trop Med Hyg. 1990;42(6):527-31.

Gruner AC, Mauduit M, Tewari R, Romero JF, Depinay N, Kayibanda M, et al. Sterile protection against malaria is independent of immune responses to the circumsporozoite protein. PLoS One. 2007;2(12):e1371.

Guerra CA, Howes RE, Patil AP, Gething PW, Van Boeckel TP, Temperley WH, et al. The international limits and population at risk of plasmodium vivax transmission in 2009. PLoS Negl Trop Dis. 2010;4(8):e774.

Gupta RK, Siber GR. Method for quantitation of igg subclass antibodies in mouse serum by enzyme-linked immunosorbent assay. J Immunol Methods. 1995;181(1):75-81.

Hafalla JC, Bauza K, Friesen J, Gonzalez-Aseguinolaza G, Hill AV, Matuschewski K. Identification of targets of $\mathrm{cd} 8(+) \mathrm{t}$ cell responses to malaria liver stages by genome-wide epitope profiling. PLoS Pathog. 2013;9(5):e1003303.

Hafalla JC, Silvie O, Matuschewski K. Cell biology and immunology of malaria. Immunol Rev. 2011;240(1):297-316.

Herrington DA, Nardin EH, Losonsky G, Bathurst IC, Barr PJ, Hollingdale MR, et al. Safety and immunogenicity of a recombinant sporozoite malaria vaccine against plasmodium vivax. Am J Trop Med Hyg. 1991;45(6):695-701.

Hill AV. Vaccines against malaria. Philos Trans $\mathrm{R}$ Soc Lond B Biol Sci. 2011;366(1579):2806-14.

Hoffman SL, Billingsley PF, James E, Richman A, Loyevsky M, Li T, et al. Development of a metabolically active, non-replicating sporozoite vaccine to prevent plasmodium falciparum malaria. Hum Vaccin. 2010;6(1):97-106. 
John GK, Douglas NM, von Seidlein L, Nosten F, Baird JK, White NJ, et al. Primaquine radical cure of plasmodium vivax: A critical review of the literature. Malar J. 2012;11:280.

Kappe SH, Buscaglia CA, Nussenzweig V. Plasmodium sporozoite molecular cell biology. Annu Rev Cell Dev Biol. 2004;20:29-59.

Kastenmuller K, Espinosa DA, Trager L, Stoyanov C, Salazar AM, Pokalwar S, et al. Fulllength plasmodium falciparum circumsporozoite protein administered with long-chain poly(i.C) or the toll-like receptor 4 agonist glucopyranosyl lipid adjuvant-stable emulsion elicits potent antibody and cd4 $+\mathrm{t}$ cell immunity and protection in mice. Infect Immun. 2012;81(3):789-800.

Kebaier C, Voza T, Vanderberg J. Kinetics of mosquito-injected plasmodium sporozoites in mice: Fewer sporozoites are injected into sporozoite-immunized mice. PLoS Pathog. 2009;5(4):e1000399.

Kester KE, Cummings JF, Ofori-Anyinam O, Ockenhouse CF, Krzych U, Moris P, et al. Randomized, double-blind, phase $2 \mathrm{a}$ trial of falciparum malaria vaccines $\mathrm{rts}, \mathrm{s} / \mathrm{as} 01 \mathrm{~b}$ and rts,s/as02a in malaria-naive adults: Safety, efficacy, and immunologic associates of protection. J Infect Dis. 2009;200(3):337-46.

Kumar KA, Sano G, Boscardin S, Nussenzweig RS, Nussenzweig MC, Zavala F, et al. The circumsporozoite protein is an immunodominant protective antigen in irradiated sporozoites. Nature. 2006;444(7121):937-40.

Lacerda MV, Mourao MP, Alexandre MA, Siqueira AM, Magalhaes BM, Martinez-Espinosa FE, et al. Understanding the clinical spectrum of complicated plasmodium vivax malaria: A systematic review on the contributions of the brazilian literature. Malar J. 2012;11:12.

Lacroix C, Menard R. Trap-like protein of plasmodium sporozoites: Linking gliding motility to host-cell traversal. Trends Parasitol. 2008;24(10):431-4.

Leach A, Vekemans J, Lievens M, Ofori-Anyinam O, Cahill C, Owusu-Agyei S, et al. Design of a phase iii multicenter trial to evaluate the efficacy of the rts,s/as01 malaria vaccine in children across diverse transmission settings in africa. Malar J. 2011;10:224.

Leal MT, Camacho AG, Teixeira LH, Bargieri DY, Soares IS, Tararam CA, et al. Immunogenicity of recombinant proteins consisting of plasmodium vivax circumsporozoite protein allelic variant-derived epitopes fused with salmonella enterica serovar typhimurium flagellin. Clin Vaccine Immunol. 2013;20(9):1418-25.

Li S, Rodrigues M, Rodriguez D, Rodriguez JR, Esteban M, Palese P, et al. Priming with recombinant influenza virus followed by administration of recombinant vaccinia virus induces cd8+ t-cell-mediated protective immunity against malaria. Proc Natl Acad Sci U S A. 1993;90(11):5214-8.

Lumsden JM, Nurmukhambetova S, Klein JH, Sattabongkot J, Bennett JW, Bertholet S, et al. Evaluation of immune responses to a plasmodium vivax csp-based recombinant protein 
vaccine candidate in combination with second-generation adjuvants in mice. Vaccine. 2012;30(22):3311-9.

Lumsden JM, Pichyangkul S, Srichairatanakul U, Yongvanitchit K, Limsalakpetch A, Nurmukhambetova $S$, et al. Evaluation of the safety and immunogenicity in rhesus monkeys of a recombinant malaria vaccine for plasmodium vivax with a synthetic toll-like receptor 4 agonist formulated in an emulsion. Infect Immun. 2011;79(9):3492-500.

Marques MM, Costa MR, Santana Filho FS, Vieira JL, Nascimento MT, Brasil LW, et al. Plasmodium vivax chloroquine resistance and anemia in the western brazilian amazon. Antimicrob Agents Chemother. 2013.

Matthews K, Chung NP, Klasse PJ, Moutaftsi M, Carter D, Salazar AM, et al. Clinical adjuvant combinations stimulate potent b-cell responses in vitro by activating dermal dendritic cells. PLoS One. 2013;8(5):e63785.

McElrath MJ, De Rosa SC, Moodie Z, Dubey S, Kierstead L, Janes H, et al. Hiv-1 vaccineinduced immunity in the test-of-concept step study: A case-cohort analysis. Lancet. 2008;372(9653):1894-905.

Menard R, Tavares J, Cockburn I, Markus M, Zavala F, Amino R. Looking under the skin: The first steps in malarial infection and immunity. Nat Rev Microbiol. 2013;11(10):701-12.

Mendes C, Dias F, Figueiredo J, Mora VG, Cano J, de Sousa B, et al. Duffy negative antigen is no longer a barrier to plasmodium vivax--molecular evidences from the african west coast (angola and equatorial guinea). PLoS Negl Trop Dis. 2011;5(6):e1192.

Mishra S, Nussenzweig RS, Nussenzweig V. Antibodies to plasmodium circumsporozoite protein (csp) inhibit sporozoite's cell traversal activity. J Immunol Methods. 2012;377(12):47-52.

Montagna GN, Matuschewski K, Buscaglia CA. Plasmodium sporozoite motility: An update. Front Biosci (Landmark Ed). 2012;17:726-44.

Moon JJ, Suh H, Li AV, Ockenhouse CF, Yadava A, Irvine DJ. Enhancing humoral responses to a malaria antigen with nanoparticle vaccines that expand th cells and promote germinal center induction. Proc Natl Acad Sci U S A. 2012;109(4):1080-5.

Moon JJ, Suh H, Polhemus ME, Ockenhouse CF, Yadava A, Irvine DJ. Antigen-displaying lipid-enveloped plga nanoparticles as delivery agents for a plasmodium vivax malaria vaccine. PLoS One. 2012;7(2):e31472.

Mota MM, Rodriguez A. Migration through host cells: The first steps of plasmodium sporozoites in the mammalian host. Cell Microbiol. 2004;6(12):1113-8.

Mueller AK, Camargo N, Kaiser K, Andorfer C, Frevert U, Matuschewski K, et al. Plasmodium liver stage developmental arrest by depletion of a protein at the parasite-host interface. Proc Natl Acad Sci U S A. 2005;102(8):3022-7. 
Murphy SC, Kas A, Stone BC, Bevan MJ. A t-cell response to a liver-stage plasmodium antigen is not boosted by repeated sporozoite immunizations. Proc Natl Acad Sci U S A. 2013;110(15):6055-60.

Nardin EH, Nussenzweig RS. T cell responses to pre-erythrocytic stages of malaria: Role in protection and vaccine development against pre-erythrocytic stages. Annu Rev Immunol. 1993;11:687-727.

Nussenzweig RS, Vanderberg J, Most H, Orton C. Protective immunity produced by the injection of X-irradiated sporozoites of plasmodium berghei. Nature. 1967;216(5111):160-2.

Oliveira-Ferreira J, Lacerda MV, Brasil P, Ladislau JL, Tauil PL, Daniel-Ribeiro CT. Malaria in brazil: An overview. Malar J. 2010;9:115.

Olotu A, Lusingu J, Leach A, Lievens M, Vekemans J, Msham S, et al. Efficacy of rts,s/as01e malaria vaccine and exploratory analysis on anti-circumsporozoite antibody titres and protection in children aged 5-17 months in kenya and tanzania: A randomised controlled trial. Lancet Infect Dis. 2011;11(2):102-9.

Olotu A, Moris P, Mwacharo J, Vekemans J, Kimani D, Janssens M, et al. Circumsporozoitespecific $\mathrm{t}$ cell responses in children vaccinated with $\mathrm{rts}, \mathrm{s} / \mathrm{as} 01 \mathrm{e}$ and protection against $\mathrm{p}$ falciparum clinical malaria. PLoS One. 2011;6(10):e25786.

Olotu A, Fegan G, Wambua J, Nyangweso G, Awuondo KO, Leach A, et al. Four-year efficacy of RTS,S/AS01E and its interaction with malaria exposure. N Engl J Med. 2013 Mar 21;368(12):1111-20.

Park H, Adamson L, Ha T, Mullen K, Hagen SI, Nogueron A, et al. Polyinosinicpolycytidylic acid is the most effective tlr adjuvant for siv gag protein-induced $t$ cell responses in nonhuman primates. J Immunol. 2013;190(8):4103-15.

Parroche P, Lauw FN, Goutagny N, Latz E, Monks BG, Visintin A, et al. Malaria hemozoin is immunologically inert but radically enhances innate responses by presenting malaria DNA to toll-like receptor 9. Proc Natl Acad Sci U S A. 2007;104(6):1919-24.

PATH-MVI. Malaria Vaccine Initiative. Accelerating Malaria Vaccine Development. RTS,S trial sites [mapa] [Internet]. 2014. [acesso em 06 jan 2014]. Disponível em: http://www.malariavaccine.org/rd-trial-sites.php.

PATH-MVI. Malaria Vaccine Initiative. Accelerating Malaria Vaccine Development. RTS,S malaria vaccine candidate. 2014. [acesso em 06 jan 2014]. Disponível em: http://www.malariavaccine.org/rd-rtss.php.

Price RN, Tjitra E, Guerra CA, Yeung S, White NJ, Anstey NM. Vivax malaria: Neglected and not benign. Am J Trop Med Hyg. 2007;77(6 Suppl):79-87.

Rappuoli R, Medaglini D. Aditec: Joining forces for next-generation vaccines. Sci Transl Med. 2012;4(128):128cm4.

Rieckmann KH, Beaudoin RL, Cassells JS, Sell KW. Use of attenuated sporozoites in the immunization of human volunteers against falciparum malaria. Bull World Health Organ. 1979;57 Suppl 1:261-5. 
Rodrigues M, Nussenzweig RS, Romero P, Zavala F. The in vivo cytotoxic activity of cd8+t cell clones correlates with their levels of expression of adhesion molecules. J Exp Med. 1992;175(4):895-905.

Rodrigues MM, Cordey AS, Arreaza G, Corradin G, Romero P, Maryanski JL, et al. Cd8+ cytolytic $t$ cell clones derived against the plasmodium yoelii circumsporozoite protein protect against malaria. Int Immunol. 1991;3(6):579-85.

Romero P, Maryanski JL, Corradin G, Nussenzweig RS, Nussenzweig V, Zavala F. Cloned cytotoxic $\mathrm{t}$ cells recognize an epitope in the circumsporozoite protein and protect against malaria. Nature. 1989;341(6240):323-6.

Schmidt NW, Podyminogin RL, Butler NS, Badovinac VP, Tucker BJ, Bahjat KS, et al. Memory cd8 $\mathrm{t}$ cell responses exceeding a large but definable threshold provide long-term immunity to malaria. Proc Natl Acad Sci U S A. 2008;105(37):14017-22.

Schneider J, Gilbert SC, Blanchard TJ, Hanke T, Robson KJ, Hannan CM, et al. Enhanced immunogenicity for $\mathrm{cd} 8+\mathrm{t}$ cell induction and complete protective efficacy of malaria DNA vaccination by boosting with modified vaccinia virus ankara. Nat Med. 1998;4(4):397-402.

Schofield L, Villaquiran J, Ferreira A, Schellekens H, Nussenzweig R, Nussenzweig V. Gamma interferon, cd8+ $\mathrm{t}$ cells and antibodies required for immunity to malaria sporozoites. Nature. 1987;330(6149):664-6.

Schwenk RJ, Richie TL. Protective immunity to pre-erythrocytic stage malaria. Trends Parasitol. 2011;27(7):306-14.

Secretaria de Vigilância em Saúde. Portal da saúde - Malária: situação epidemiológica. 2012. [acesso em 11 fev 2013]. Disponível em: http://portal.saude.gov.br/portal/saude/profissional/visualizar_texto.cfm?idtxt=31086\&janela $=2$.

Seder RA, Chang LJ, Enama ME, Zephir KL, Sarwar UN, Gordon IJ, et al. Protection against malaria by intravenous immunization with a nonreplicating sporozoite vaccine. Science. 2013;341(6152):1359-65.

Shanmugasundram A, Gonzalez-Galarza FF, Wastling JM, Vasieva O, Jones AR. Library of apicomplexan metabolic pathways: A manually curated database for metabolic pathways of apicomplexan parasites. Nucleic Acids Res. 2012;41(Database issue):D706-13.

Sinnis P, Zavala F. The skin: Where malaria infection and the host immune response begin. Semin Immunopathol. 2012;34(6):787-92.

Soares IS, Francoso KS, Jampaulo VO, Rodrigues MM. Cd8(+) t-cell-mediated immunity against malaria: A novel heterologous prime-boost strategy. Expert Rev Vaccines. 2012;11(9):1039-41.

Spring M, Murphy J, Nielsen R, Dowler M, Bennett JW, Zarling S, et al. First-in-human evaluation of genetically attenuated plasmodium falciparum sporozoites administered by bite of anopheles mosquitoes to adult volunteers. Vaccine. 2013;31(43):4975-83. 
Suwanarusk R, Cooke BM, Dondorp AM, Silamut K, Sattabongkot J, White NJ, et al. The deformability of red blood cells parasitized by plasmodium falciparum and p. Vivax. J Infect Dis. 2004;189(2):190-4.

Tam JP, Clavijo P, Lu YA, Nussenzweig V, Nussenzweig R, Zavala F. Incorporation of $t$ and $\mathrm{b}$ epitopes of the circumsporozoite protein in a chemically defined synthetic vaccine against malaria. J Exp Med. 1990;171(1):299-306.

Tao D, Barba-Spaeth G, Rai U, Nussenzweig V, Rice CM, Nussenzweig RS. Yellow fever $17 \mathrm{~d}$ as a vaccine vector for microbial ctl epitopes: Protection in a rodent malaria model. J Exp Med. 2005;201(2):201-9.

Tauil PL. The prospect of eliminating malaria transmission in some regions of brazil. Mem Inst Oswaldo Cruz. 2011;106 Suppl 1:105-6.

Teixeira LH, Tararam CA, Lasaro MO, Camacho AG, Ersching J, Leal MT, et al. Immunogenicity of a prime-boost vaccine containing the circumsporozoite proteins of plasmodium vivax in rodents. Infect Immun. 2013.

Tsuji M. A retrospective evaluation of the role of $t$ cells in the development of malaria vaccine. Exp Parasitol. 2010;126(3):421-5.

Vasconcelos JR, Dominguez MR, Araujo AF, Ersching J, Tararam CA, Bruna-Romero O, et al. Relevance of long-lived cd8(+) t effector memory cells for protective immunity elicited by heterologous prime-boost vaccination. Front Immunol. 2012;3:358.

Vaughan AM, Kappe SH. Malaria vaccine development: Persistent challenges. Curr Opin Immunol. 2012;24(3):324-31.

Weiss WR, Sedegah M, Beaudoin RL, Miller LH, Good MF. Cd8+ $t$ cells (cytotoxic/suppressors) are required for protection in mice immunized with malaria sporozoites. Proc Natl Acad Sci U S A. 1988;85(2):573-6.

White NJ. Determinants of relapse periodicity in plasmodium vivax malaria. Malar J. 2011;10:297.

Yadava A, Nurmukhambetova S, Pichugin AV, Lumsden JM. Cross-species immunity following immunization with a circumsporozoite protein-based vaccine for malaria. $\mathrm{J}$ Infect Dis. 2012;205(9):1456-63.

Yadava A, Sattabongkot J, Washington MA, Ware LA, Majam V, Zheng H, et al. A novel chimeric plasmodium vivax circumsporozoite protein induces biologically functional antibodies that recognize both vk210 and vk247 sporozoites. Infect Immun. 2007;75(3):117785 .

Yoshida N, Nussenzweig RS, Potocnjak P, Nussenzweig V, Aikawa M. Hybridoma produces protective antibodies directed against the sporozoite stage of malaria parasite. Science. 1980;207(4426):71-3. 
WHO. World Health Organization: World Malaria Report. 2011. [acesso em 03 abr 2012]. Disponível

em: http://www.who.int/malaria/world_malaria_report_2011/WMR2011_noprofiles_lowres.pdf.

World malaria report 2013. Geneva, World Health Organization. 2013. [acesso em 06 jan 2014]. Disponível em: http:// www.who.int/iris/bitstream/10665/97008/1/9789241564694_eng.pdf.

Zhou D, Zhou X, Bian A, Li H, Chen H, Small JC, et al. An efficient method of directly cloning chimpanzee adenovirus as a vaccine vector. Nat Protoc. 2010;5(11):1775-85. 
APÊNDICES 


\section{APÊNDICE A}

"TLR5-dependent immunogenicity of a recombinant fusion protein containing an immunodominant epitope of malarial circumsporozoite protein and the FliC flagellin of Salmonella Typhimurium." (Camacho et al., 2011) 


\title{
TLR5-dependent immunogenicity of a recombinant fusion protein containing an immunodominant epitope of malarial circumsporozoite protein and the FliC flagellin of Salmonella Typhimurium
}

\author{
Ariane Guglielmi Ariza Camacho', ${ }^{1,2}$, Laís Helena Teixeira ${ }^{1,3}$, Daniel Youssef Bargieri ${ }^{1,2}$, \\ Silvia Beatriz Boscardin ${ }^{3}$, Irene da Silva Soares ${ }^{4}$, Ruth Sonntag Nussenzweig ${ }^{5,6}$, \\ Victor Nussenzweig ${ }^{6}$, Mauricio Martins Rodrigues ${ }^{1,2}{ }^{+}$
}
${ }^{1}$ Centro de Terapia Celular e Molecular 2Departamento de Microbiologia, Imunologia e Parasitologia, Escola Paulista de Medicina, Universidade Federal de São Paulo, Rua Mirassol 207, 04044-010 São Paulo, SP, Brasil ²Departamento de Parasitologia, Instituto de Ciência Biomédicas ${ }^{4}$ Departamento de Análises Clínicas e Toxicológicas, Faculdade de Ciências Farmacêuticas, Universidade de São Paulo, São Paulo, SP, Brasil ${ }^{5}$ Michael Heidelberger Division, Department of Pathology
${ }^{6}$ Department of Medical and Molecular Parasitology, New York University School of Medicine, New York, NY, USA

Recently, we described the improved immunogenicity of new malaria vaccine candidates based on the expression of fusion proteins containing immunodominant epitopes of merozoites and Salmonella enterica serovar Typhimurium flagellin (FliC) protein as an innate immune agonist. Here, we tested whether a similar strategy, based on an immunodominant B-cell epitope from malaria sporozoites, could also generate immunogenic fusion polypeptides. A recombinant His6-tagged FliC protein containing the C-terminal repeat regions of the VK210 variant of Plasmodium vivax circumsporozoite (CS) protein was constructed. This recombinant protein was successfully expressed in Escherichia coli as soluble protein and was purified by affinity to Ni-agarose beads followed by ion exchange chromatography. A monoclonal antibody specific for the CS protein of $\mathrm{P}$. vivax sporozoites (VK210) was able to recognise the purified protein. C57BL/6 mice subcutaneously immunised with the recombinant fusion protein in the absence of any conventional adjuvant developed protein-specific systemic antibody responses. However, in mice genetically deficient in expression of TLR5, this immune response was extremely low. These results extend our previous observations concerning the immunogenicity of these recombinant fusion proteins and provide evidence that the main mechanism responsible for this immune activation involves interactions with TLR5, which has not previously been demonstrated for any recombinant FliC fusion protein.

Key words: TLR5 - flagellin - CS protein - P. vivax

Intravenous vaccination with radiation-attenuated sporozoites (RAS) of Plasmodium can provide solid protection against malaria (Nussenzweig et al. 1967). Immunity generated by vaccination with RAS sporozoites is targeted towards a dominant protective antigen, the circumsporozoite (CS) protein (Kumar et al. 2006). Nevertheless, there exist other protective antigens yet to be characterised (Kumar et al. 2006, Mauduit et al. 2009). Following immunisation with RAS, the CS protein is recognised by antibodies and $\mathrm{CD} 4^{+}$and $\mathrm{CD} 8^{+} \mathrm{T}$ cells that can eliminate pre-erythrocytic stages of the parasite (Nardin et al. 1989, Romero et al. 1989, Malik et al. 1991, Rénia et al. 1991, Rodrigues et al. 1991). These results led to the development of vaccine formulations aimed at eliciting high

Financial support: FAPESP (2009/15132-4), INCTV-CNPq (to MMR, ISS, SBB), CNPq (to MMR, ISS, AGC), CAPES (to LHT), FAPESP (to DYB) AGC, ISS and MMR are recipients of fellowships from CNPq, LHT is supported by a fellowship from CAPES and DYB is supported by a Manlio Cantarini fellowship.

+Corresponding author: mrodrigues@unifesp.br

Received 14 February 2011

Accepted 27 April 2011 antibody titres against sporozoites and/or large numbers of $\mathrm{CD}^{+}$and $\mathrm{CD} 8^{+} \mathrm{T}$ cells specific for liver stage components of malaria (reviewed by Bargieri et al. 2011).

Confirmation that the CS protein can be used for a human vaccine came from recent studies using the deadly parasite Plasmodium falciparum. This vaccine formulation consisted of a large C-terminal fragment of the CS protein fused to the antigen $\mathrm{S}$ of hepatitis $\mathrm{B}$ (conventional hepatitis B vaccine, Engerix $B^{\circledR}$ ) and was expressed as a recombinant protein in Saccharomyces cerevisiae. The fusion protein, named RTS, when expressed with antigen S, naturally assembles into virus-like particles called RTS,S. The efficacy of the RTS,S formulation depended on the use of adjuvant systems (AS) consisting of two different formulations of monophosphoryl lipid A (a detoxified form of lipopolysaccharides) and QS21 (saponin purified from Quillaja saponaria) in either an oil-in-water emulsion (AS02) or a liposomal suspension (AS01) (Cohen et al. 2010).

Recent Phase II trials in naïve human volunteers challenged with $P$. falciparum sporozoites found efficacies ranging from $32-50 \%$. Immunological studies performed on these vaccinated individuals indicated that protection correlated with the concentration of specific antibodies and the frequency of interferon gamma (IFN$\gamma)$-producing cells detected by enzyme-linked immuno- 
sorbent spot (Kester et al. 2009). A number of Phase IIb trials have been completed and others continue to be carried out in the field. Although results from field trials are more difficult to interpret, studies performed in children in the endemic areas have shown between $49.5-62 \%$ efficacy in retarding the first malaria episode during the six-month period studied (Abdulla et al. 2008, Bejon et al. 2008). As protective immunity was found to be highly dependent on the adjuvants used in the formulation, these studies highlight the importance of adjuvant development for an effective malaria vaccine. Similar studies with the CS protein of Plasmodium vivax have been initiated but have not reported findings to date.

Based on the ability of flagellin to efficiently induce humoral and cellular immune responses against foreign antigens, we explored the use of this molecule for the generation of fusion proteins containing malarial antigens. For our initial studies, we selected the 19-kDa Cterminal region of merozoite surface protein-1 $\left(\mathrm{MSP}^{-} \mathrm{1}_{19}\right)$ from P. vivax or P. faciparum. MSP-1 $1_{19}$ was fused to the C-terminal end of FliC flagellin from Salmonella typhimurium. This fusion protein was able to bind and activate TLR5 expressed by in vitro-cultured transfected cells and it was recognised by serum from patients with $P$. vivax malaria. Moreover, the fusion protein was recognised by monoclonal antibodies against three-dimensional structural epitopes of MSP- $_{19}$, which indicated that it was correctly folded when expressed in Escherichia coli (Bargieri et al. 2008, 2010).

We immunised mice and rabbits with recombinant fusion protein in the absence of additional adjuvant. Immunised animals developed strong, specific and longlasting antibody-mediated responses. Antibody titres after the second immunisation were similar to those following immunisation with recombinant $\mathrm{MSP}_{19}$ emulsified in complete/incomplete Freund's adjuvant. Additionally, the antibodies generated by these immunisations recognised $P$. vivax or $P$. falciparum merozoites as detected by immunofluorescence (Bargieri et al. 2008, 2010). Most importantly, rabbits injected with PfMSP- $1_{19}$ fused to flagellin raised high antibody titres that dramatically inhibited the in vitro growth of the parasite lines 3D7, S20 and FCR3 (Bargieri et al. 2010).

In the absence of other adjuvant, the immune response following immunisation was biased toward a type 2 response with a high IgG1/2 ratio and limited amounts of IFN- $\gamma$ secretion by splenic immune cells. Nevertheless, the addition of other adjuvants to the fusion protein, such as a TLR-9 agonist, modulated the immune response towards a type 1 response with a lower $\operatorname{IgGl} / 2$ ratio and significantly greater secretion of IFN- $\gamma$ (Bargieri et al. 2008).

In this study, we have investigated the immunogenicity of a fusion polypeptide containing the immunodominant region of the CS protein from P. vivax and the innate immune agonist Salmonella Typhimurium FliC flagellin. The immunogenicity of the recombinant fusion protein was assessed by immunisation of mice with the recombinant protein alone. Additionally, we investigated whether the antibody response was dependent on expression of the TLR5 molecule.

\section{MATERIALS AND METHODS}

Generation of the recombinant protein His${ }_{6}$ FliC-PvCS-VK210 - Generation of the original plasmid has been described previously (Bargieri et al. 2008). The $M S P-1_{19}$ gene was removed by treatment with the enzymes HindIII and XhoI. The synthetic gene containing the sequence of nucleotides CAAGCTTGCGCAAGCGATATGGCGAAAAAAGAA ACCGT GT GGCGTC T GGA A GA A T T TGGCCGTTTCGATCGTGCAGATGGTCAGCCGGCAGGTGACCGCGCCGACGGTCAGCCGGCAGGTGATCGTGCAGCCGGTCAGCCGGCGGGTGATCGTGCAGCGGGCCAGCCGGCGGGTGATCGCGCCGATGGTCAACCGGCCGGTGATGACCGCGCCGATGGCCAACCGGCCGGTGACCGCGCCGAT G GTCA GC CGGCCGGCGAC CGCGCCGCCGGCCAACCGGCCGGCGACCGCGCAGCCGGCCAACCGGCCGGTGATCGCGCAGATGGTCAGCCGGCCGGTGATTAACTCGAG was cloned into this vector. Regions in underlined font represent recognition sites for HindIII and XhoI. The recombinant protein was expressed and purified as described previously (Bargieri et al. 2008). Briefly, recombinant E. coli BL21 DE3 (Novagen) was cultivated at $37^{\circ} \mathrm{C}$ in flasks containing Luria broth (LB) and kanamycin $(30 \mu \mathrm{g} / \mathrm{mL})$. Protein expression was induced at an $\mathrm{OD}_{600}$ of 0.6 with $0.1 \mathrm{mM}$ IPTG (Invitrogen) for $4 \mathrm{~h}$. After centrifugation, bacteria were lysed on ice with an ultrasonic processor (Sonics \& Materials INC, Vibra Cell VCX 750 ) in a phosphate buffer with $1.0 \mathrm{mg} / \mathrm{mL}$ lysozyme (Sigma) and 1mM PMSF (Sigma). Bacterial lysates were centrifuged and the supernatant was applied to a column containing $\mathrm{Ni}^{2+}$-NTA-agarose resin (Quiagen). After several washes, bound protein was eluted with 0.5 M imidazole (Sigma). Eluted protein was dialysed against $20 \mathrm{mM}$ Tris- $\mathrm{HCl}(\mathrm{pH} 8.0)$ and the recombinant protein was purified by ion-exchange chromatography using a Resource Q column (GE Healthcare) coupled to an FPLC system (GE Healthcare). Fractions containing highly pure recombinant protein were pooled and extensively dialysed against phosphate-buffered saline (PBS) ( $\mathrm{pH}$ 7.2). Protein concentration was determined by the Bradford assay and by sodium dodecyl sulfate polyacrylamide gel electrophoresis (SDS-PAGE) analyses.

FliC purification - Native Salmonella Typhimurium FliC was purified from the attenuated Salmonella Typhimurium SL3201 strain, which expresses FliC but not $\mathrm{FljB}$ (Bargieri et al. 2008). Briefly, bacteria were grown in LB supplemented with kanamycin $(30 \mu \mathrm{g} / \mathrm{mL})$ overnight at $37^{\circ} \mathrm{C}$ under aeration ( $\left.80 \mathrm{rpm}\right)$. Cells were washed once with PBS and submitted to mechanical shearing during four 2 min cycles in a bench vortex mixer. The cell suspensions were centrifuged to remove cellular debris and, following acetone precipitation, the flagellar filaments were collected from the supernatant and suspended in PBS. The purity of the preparations was monitored by SDS-PAGE.

Immunisation regimens - Six-eight-week-old female C57BL/6 (H-2 $\left.{ }^{b}\right)$ or genetically deficient TLR5 (KO) (Feuillet et al. 2006) mice were purchased from the Fed- 
eral University of São Paulo (UNIFESP), Brazil. Mice were immunised subcutaneously three times each three weeks apart. The first immunisation was given in the hind footpads with a final volume of $50 \mu \mathrm{L}$ in each footpad and the second and third immunisations were in the base of the tail in a final volume of $100 \mu \mathrm{L}$. For each immunisation, $5 \mu \mathrm{g}$ or $10 \mu \mathrm{g}$ of fusion protein or FliC was used.

Immunological assays - For immunologic characterisation, proteins on SDS-PAGE gels were transferred electrophoretically onto nitrocellulose membranes (Millipore, CA, USA). The membranes were blocked for up to $1 \mathrm{~h}$ using nonfat milk in PBS $(5 \% \mathrm{w} / \mathrm{vol})$ and bovine serum albumin $(2 \% \mathrm{w} / \mathrm{vol})$ containing $0.1 \%$ Tween 20 (PBS-T). After washing with $0.05 \%$ PBS-T, the blots were incubated for $1 \mathrm{~h}$ at room temperature with the appropriate primary antibody diluted in PBS-T. The primary antibodies used were the following: (i) mouse monoclonal antibodies (MAb) to $\mathrm{His}_{6}$ (Amersham/GE) diluted 1:1,000, (ii) MAb 2F2 to PvCS protein from the VK210 strain $(1 \mu \mathrm{g} / \mathrm{mL})$ (Nardin et al. 1982) and (iii) MAb to PvCS protein from the VK247 strain. After washing, peroxidase-labeled goat anti-mouse IgG (Sigma, St. Louis, Mo) diluted 1:1,000 was added for $1 \mathrm{~h}$. The blots were then washed and developed with diaminobenzidin solution $(0.285 \mathrm{mg} / \mathrm{mL}$, Sigma).

Serum anti-PvCS antibodies were detected by enzyme linked immunosorbent assay (ELISA) as described previously (Bargieri et al. 2008). Recombinant $\mathrm{His}_{6} \mathrm{PvCS}$ protein $(200 \mathrm{ng} /$ well $)$ was used as the solid phase-bound antigen. This recombinant protein contains the entire PvCS protein, including the $\mathrm{N}$ and $\mathrm{C}$-terminal portions and repeats (VK210) and further information will be published in detail elsewhere. Mouse sera were tested at serial dilutions starting at 1:200 and a peroxidase-conjugated goat anti-mouse IgG (Sigma) was applied at a final dilution of 1:1,000. Anti-PvCS antibody titres were determined for the highest dilution yielding an $\mathrm{OD}_{492}$ greater than 0.1 . The results are presented as mean \pm standard deviation.

Statistical analyses - The one-way analysis of variance (ANOVA), Student's $t$ test, Tukey honestly significant difference test and Kruskal-Wallis ANOVA were used to compare the differences between the mean values of the tested immunisation groups.

Ethics - The use of animals and the experimental procedures, including the number of mice per experimental group, have been approved by the Ethics Committee for Animal Care of the UNIFESP (Id \# CEP 0307/09).

\section{RESULTS}

Production and purification of flagellin fusion protein - We generated a recombinant fusion protein containing a hexa-histidine tag $\left(\mathrm{His}_{6}\right)$ consisting of the immunodominant region of the PvCS protein (VK210 strain) linked to the C-terminal end of FliC (His FliC-PvCS-VK210). The schematic representations of the recombinant polypeptide and purified protein are presented in Fig. 1A, B, respectively. The purified protein migrated under denatured and reduced condition as a main band of $\sim 65 \mathrm{kDa}$ and a larger band of $\sim 130 \mathrm{kDa}$. Both bands were deter-
A
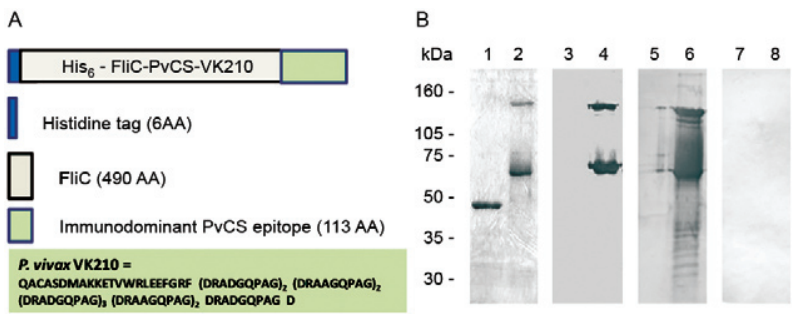

Fig. 1: generation and characterisation of recombinant Plasmodium vivax circumsporozoite protein VK 210 strain. A: schematic representation of the recombinant protein used in the present study; B: sodium dodecyl sulfate polyacrylamide gel electrophoresis (SDS-PAGE) and immunoblot analysis of the recombinant protein. Lanes 1, 2: SDSPAGE of purified Salmonella Typhimurium FliC flagellin and $\mathrm{His}_{6}-$ FliC-PvCS-VK210 proteins, respectively; 3, 4: immunoblot of the same two proteins described in Lanes 1, 2 probed with a mouse monoclonal antibodies (MAb) to $\mathrm{His}_{6}$; 5, 6: immunoblot of the same two proteins described in Lanes 1,2 probed with a MAb to repeats of PvCS protein VK210 strain; 7, 8: immunoblot of the same two proteins described in Lanes 1, 2 probed with a MAb to repeats of PvCS protein VK247 strain. Each Lane was loaded with approximately $1 \mu \mathrm{g}$ of protein separated on a 15\% SDS-PAGE and stained with Coomassie Blue (Lanes 1, 2).

mined to be recombinant protein by the recognition of the His ${ }_{6}$ MAb (Fig. 1B, Lanes 3, 4). The larger band most likely represents a dimeric form of the recombinant protein. The native FliC protein purified from monophasic Salmonella Typhimurium of strain SL3201 migrated as predicted at $\sim 49 \mathrm{kDa}$ (Fig. 1B, Lane 1) and was used as a control in immunologic assays.

To determine whether the fusion polypeptide retained the ability to be recognised by the MAb 2F2 specific for the immunodominant epitope of the PvCS protein of strain VK210, we performed ELISA and immunoblot assays. This MAb recognised the recombinant protein in both assays. Fig. 1B, Lane 6 shows the immunoblot confirming recognition of the recombinant protein $\mathrm{His}_{6}$ FliC-PvCS-VK210 by MAb 2F2 (Nardin et al. 1982). This epitope was not recognised by a MAb to the immunodominant epitope of the PvCS protein from strain VK247 (Fig. 1B, Lane 8). In control experiments, this MAb recognised the PvCS protein from the VK247 strain (LHT, unpublished observations).

Induction of PvCS protein-specific antibody responses in mice immunised with $\mathrm{His}_{6}$ FliC-PvCS-VK210 The serum IgG responses to PvCS protein of the VK210 strain were determined in C57BL/6 mice immunised subcutaneously with purified $\mathrm{His}_{6}$ FliC-PvCS-VK210 protein $(5 \mu \mathrm{g} / \mathrm{dose} / \mathrm{mouse})$. Mice parenterally immunised with the recombinant protein developed significant levels of specific IgG titres. Maximal IgG antibody titres were achieved after the second immunisation (Fig. 2), as a third immunising dose was not found to improve antibody titres $(p>0.05)$. These titres were maintained for 15 weeks ( 9 weeks after the third dose) (Fig. 2).

TLR5-dependence on PvCS protein-specific antibody responses in mice immunised with His FliC-PvCS-VK210 - Because FliC activates a variety of innate pattern-asso- 


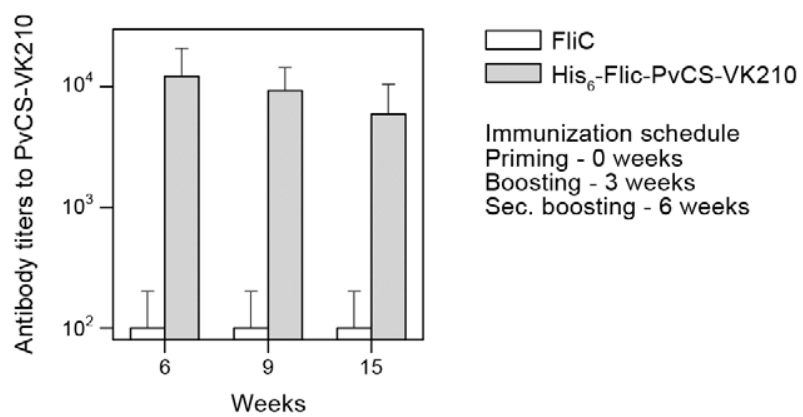

Fig. 2: detection of total IgG responses to $\mathrm{His}_{6}-\mathrm{PvCS}_{\mathrm{V}} \mathrm{VK} 210$ in serum samples of immunised mice. Female C57BL/6 mice were immunised three times with $5 \mu \mathrm{g}$ of the purified Salmonella Typhimurium FliC flagellin or $\mathrm{His}_{6}$-FliC-PvCS-VK210 proteins antibody titres were detected by conventional enzyme linked immunosorbent assay. Data are representative of two experiments using five mice per group.

ciated receptors during the immune response to flagellin (Sanders et al. 2009, Mizel \& Bates 2010, Vijay-Kumar et al. 2010), we sought to determine whether TLR5 was particularly important for this process in response to immunisation. To this end, we immunised WT C57BL6 mice or TLR5 KO mice with His ${ }_{6}$ FliC-PvCS-VK210. Three weeks after the second dose, we evaluated serum antibody titres in these animals. As shown in Fig. 3, the antibody titres from immunised TLR5 KO mice represented only $3.24 \%$ of the titres detected from WT immunised mice. These results unequivocally demonstrate that the main route for immune activation following immunisation with our fusion recombinant protein was via TLR5.

\section{DISCUSSION}

In the present study, we tested whether a straightforward and inexpensive fusion protein containing the prototypic innate immune activator FliC from Salmonella and an immunodominant epitope from the malaria sporozoite could elicit specific humoral immune responses to the $\mathrm{CS}$ protein, the best-studied malaria vaccine candidate. From our studies, we concluded that parenteral immunisation with the fusion protein $\mathrm{His}_{6}$ FliC-PvCS-VK210 elicited specific adaptive immune responses in vaccinated mice.

Various systems using flagellin components as carriers or adjuvants for fusion proteins containing recombinant antigens have been described in the last few years. A detailed review of these data was very recently published (Mizel \& Bates 2010). Most importantly for vaccine development, the influenza vaccine candidate VAX125, which consists of an influenza antigen fused to flagellin, was given a complete Phase I clinical trial that tested safety, reactivity, immunogenicity, tolerogenicity and escalating dose-range. The results from this trial showed recombinant flagellin to be generally welltolerated by vaccinated individuals. Importantly, $91 \%$ of individuals receiving any dose of recombinant protein developed titres of neutralising antibodies compatible with protective status against influenza infection (clinicaltrials.gov/NCT00921947) (Treanor et al. 2010).

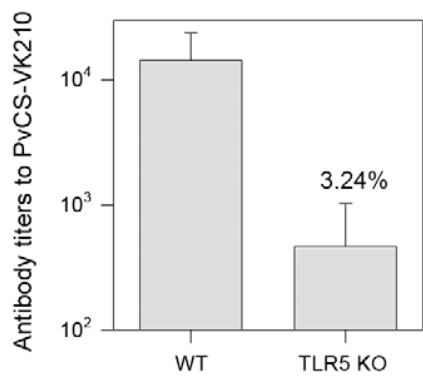

$\square$ His $_{6}$-Flic-PvCS-VK210

Immunization schedule Priming - 0 weeks Boosting - 3 weeks Antibody titers - 6 weeks

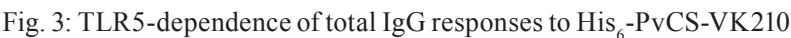
in serum samples of immunised mice. Female WT C57BL/6 or TLR5 $\mathrm{KO}$ mice were immunised twice with $10 \mu \mathrm{g}$ of the purified $\mathrm{His}_{6}-\mathrm{FliC}$ PvCS-VK 210 protein. Antibody titres were detected by conventional enzyme linked immunosorbent assay. Antibody titres of TLR5 KO were significantly lower than WT mice $(\mathrm{p}<0.001)$. Data are representative of two experiments using five mice per group.

The immunogenicity of our recombinant protein was independent of the use of conventional adjuvants, which led us to hypothesise that the main adjuvant activity seen was due to the innate immune agonist FliC. Previous studies have shown flagellin to activate multiple patternassociated molecules such as TLR5 and NLRC4 (also known as Ipaf) (Sanders et al. 2009, Mizel \& Bates 2010, Vijay-Kumar et al. 2010), which had made it difficult to determine the precise nature of the adjuvant activity using single KO mice (Sanders et al. 2009, Vijay-Kumar et al. 2010). Only very recently, by using double KO mice lacking both TLR5 and NLRC4, it was possible to demonstrate the contribution of these molecules to the adjuvant activity of flagellin when admixed to ovalbumin (VijayKumar et al. 2010). We were able to decipher the main adjuvant contribution as originating at TLR5 because the TLR5 KO mice displayed significantly impaired immune responses after vaccination (Fig. 3). One likely explanation for such dominance of the TLR5 pathway comes from a very recently published article that found the adjuvant activity of flagellin to rely on the ability of TLR5 to function as an endocytic receptor and thereby enhance specific immune responses (Letran et al. 2011).

Another possible explanation for this dominance of the TLR5 pathway is that the NLRC4 activation domain of flagellin is possibly disrupted or blocked by the presence of the malarial epitope in the recombinant fusion protein. The NLRC4 activation domain is located at the D0 domain of FliC and requires the most C-terminal 35 AA of the protein. Therefore, the introduction of the malarial epitope may result in a domain that is no longer functional (Lightfield et al. 2008). Alternatively, the recombinant flagellin may not be capable of translocation to the cell cytoplasm where NLRC4 activation takes place. It will be important in the future to determine why this recombinant protein lost the ability to efficiently activate NLRC4; in the meantime, it can be a useful tool to study TLR 5 activation by flagellin that is independent of the activation of NLRC4.

In summary, the present study has reproduced and extended upon our recent reports on the use of Salmonella flagellin as an adjuvant and antigen carrier to allow for 
additional plasticity in the design and production of vaccine antigens endowed with enhanced immunogenicity for important malarial antigens. Considering the results from recent studies in humans, our findings strongly argue in favour of implementation of future clinical trials. In addition, the present study has dissected important mechanistic information on the immunostimulatory properties of these immunisations by showing that TLR5 is the primary receptor activated by our recombinant protein.

\section{REFERENCES}

Abdulla S, Oberholzer R, Juma O, Kubhoja S, Machera F, Membi C, Omari S, Urassa A, Mshinda H, Jumanne A, Salim N, Shomari M, Aebi T, Schellenberg DM, Carter T, Villafana T, Demoitié MA, Dubois MC, Leach A, Lievens M, Vekemans J, Cohen J, Ballou WR, Tanner M 2008. Safety and immunogenicity of RTS,S/ AS02D malaria vaccine in infants. N Engl J Med 359: 2533-2544.

Bargieri DY, Leite JA, Lopes SC, Sbrogio-Almeida ME, Braga CJ, Ferreira LC, Soares IS, Costa FT, Rodrigues MM 2010. Immunogenic properties of a recombinant fusion protein containing the C-terminal $19 \mathrm{kDa}$ of Plasmodium falciparum merozoite surface protein-1 and the innate immunity agonist FliC flagellin of Salmonella typhimurium. Vaccine 28: 2818-2826.

Bargieri DY, Rosa DS, Braga CJ, Carvalho BO, Costa FT, Espíndola NM, Vaz AJ, Soares IS, Ferreira LC, Rodrigues MM 2008. New malaria vaccine candidates based on the Plasmodium vivax merozoite surface protein-1 and the TLR-5 agonist Salmonella Typhimurium FliC flagellin. Vaccine 26: 6132-6142.

Bargieri DY, Soares IS, Costa FTM, Braga CJ, Ferreira LCS, Rodrigues MM 2011. Malaria vaccine development: are bacterial flagellin fusion proteins the bridge between mouse and humans? J Parasitol Res doi:10.1155/2011/965369.

Bejon P, Lusingu J, Olotu A, Leach A, Lievens M, Vekemans J, Mshamu S, Lang T, Gould J, Dubois MC, Demoitié MA, Stallaert JF, Vansadia P, Carter T, Njuguna P, Awuondo KO, Malabeja A, Abdul O, Gesase S, Mturi N, Drakeley CJ, Savarese B, Villafana T, Ballou WR, Cohen J, Riley EM, Lemnge MM, Marsh K, von Seidlein L 2008. Efficacy of RTS,S/AS01E vaccine against malaria in children 5 to 17 months of age. N Engl J Med 359: 2521-2532.

Cohen J, Nussenzweig V, Nussenzweig R, Vekemans J, Leach A 2010. From the circumsporozoite protein to the RTS, S/AS candidate vaccine. Hum Vaccin 6: 90-96.

Feuillet V, Medjane S, Mondor I, Demaria O, Pagni PP, Galán JE, Flavell RA, Alexopoulou L 2006. Involvement of Toll-like receptor 5 in the recognition of flagellated bacteria. Proc Natl Acad Sci USA 103: 12487-12492.

Kester KE, Cummings JF, Ofori-Anyinam O, Ockenhouse CF, Krzych U, Moris P, Schwenk R, Nielsen RA, Debebe Z, Pinelis E, Juompan L, Williams J, Dowler M, Stewart VA, Wirtz RA, Dubois MC, Lievens M, Cohen J, Ballou WR, Heppner DG Jr, RTS,S Vaccine Evaluation Group 2009. Randomized, double-blind, phase 2a trial of falciparum malaria vaccines RTS,S/AS01B and RTS,S/AS02A in malaria-naive adults: safety, efficacy, and immunologic associates of protection. J Infect Dis 200: 337-346.

Kumar KA, Sano G, Boscardin S, Nussenzweig RS, Nussenzweig MC, Zavala F, Nussenzweig V 2006. The circumsporozoite protein is an immunodominant protective antigen in irradiated sporozoites. Nature 444: 937-940.

Letran SE, Lee SJ, Atif SM, Uematsu S, Akira S, McSorley SJ 2011. TLR5 functions as an endocytic receptor to enhance flagellinspecific adaptive immunity. Eur J Immunol 41: 29-38.

Lightfield KL, Persson J, Brubaker SW, Witte CE, von Moltke J, Dunipace EA, Henry T, Sun YH, Cado D, Dietrich WF, Monack DM, Tsolis RM, Vance RE 2008. Critical function for Naip5 in inflammasome activation by a conserved carboxy-terminal domain of flagellin. Nat Immunol 9: 1171-1178.

Malik A, Egan JE, Houghten RA, Sadoff JC, Hoffman SL 1991. Human cytotoxic T lymphocytes against the Plasmodium falciparum circumsporozoite protein. Proc Natl Acad Sci USA 88: 3300-3304.

Mauduit M, Grüner AC, Tewari R, Depinay N, Kayibanda M, Chavatte JM, Franetich JF, Crisanti A, Mazier D, Snounou G, Rénia L 2009. A role for immune responses against non-CS components in the cross-species protection induced by immunization with irradiated malaria sporozoites. PLOS ONE 4: e7717.

Mizel SB, Bates JT 2010. Flagellin as an adjuvant: cellular mechanisms and potential. J Immunol 185: 5677-5682.

Nardin EH, Herrington DA, Davis J, Levine M, Stuber D, Takacs B, Caspers P, Barr P, Altszuler R, Clavijo P 1989. Conserved repetitive epitope recognized by $\mathrm{CD} 4^{+}$clones from a malaria-immunized volunteer. Science 246: 1603-1606.

Nardin EH, Nussenzweig V, Nussenzweig RS, Collins WE, Harinasuta KT, Tapchaisri P, Chomcharn Y 1982. Circumsporozoite proteins of human malaria parasites Plasmodium falciparum and Plasmodium vivax. J Exp Med 156: 20-30.

Nussenzweig RS, Vanderberg J, Most H, Orton C 1967. Protective immunity produced by the injection of $\mathrm{x}$-irradiated sporozoites of Plasmodium berghei. Nature 216: 160-162.

Rénia L, Marussig MS, Grillot D, Pied S, Corradin G, Miltgen F, Del Giudice G, Mazier D 1991. In vitro activity of $\mathrm{CD} 4^{+}$and $\mathrm{CD} 8^{+}$ $\mathrm{T}$ lymphocytes from mice immunized with a synthetic malaria peptide. Proc Natl Acad Sci USA 88: 7963-7967.

Rodrigues MM, Cordey AS, Arreaza G, Corradin G, Romero P, Maryanski JL, Nussenzweig RS, Zavala F 1991. CD8 ${ }^{+}$cytolytic T cell clones derived against the Plasmodium yoelii circumsporozoite protein protect against malaria. Int Immunol 3: 579-585.

Romero P, Maryanski JL, Corradin G, Nussenzweig RS, Nussenzweig V, Zavala F 1989. Cloned cytotoxic T cells recognize an epitope in the circumsporozoite protein and protect against malaria. Nature 341: 323-326.

Sanders CJ, Franchi L, Yarovinsky F, Uematsu S, Akira S, Núñez G, Gewirtz AT 2009. Induction of adaptive immunity by flagellin does not require robust activation of innate immunity. Eur J Immunol 39: 359-371.

Treanor JJ, Taylor DN, Tussey L, Hay C, Nolan C, Fitzgerald T, Liu G, Kavita U, Song L, Dark I, Shaw A 2010. Safety and immunogenicity of a recombinant hemagglutinin influenza-flagellin fusion vaccine (VAX125) in healthy young adults. Vaccine 28: 8268-8274.

Vijay-Kumar M, Carvalho FA, Aitken JD, Fifadara NH, Gewirtz AT 2010. TLR5 or NLRC4 is necessary and sufficient for promotion of humoral immunity by flagellin. Eur J Immunol 40: 3528-3534. 


\section{APÊNDICE B}

"Immunogenicity of recombinant proteins consisting of Plasmodium vivax circumsporozoite protein allelic variant-derived epitopes fused with Salmonella enterica Serovar Typhimurium flagellin." (Leal et al., 2013) 


\title{
Immunogenicity of Recombinant Proteins Consisting of Plasmodium vivax Circumsporozoite Protein Allelic Variant-Derived Epitopes Fused with Salmonella enterica Serovar Typhimurium Flagellin
}

\author{
Monica Teixeira Andrade Leal, ${ }^{\mathrm{a}, \mathrm{b}}$ Ariane Guglielmi Ariza Camacho, ${ }^{\mathrm{a}, \mathrm{b}}$ Laís Helena Teixeira, ${ }^{\mathrm{a}, \mathrm{c}}$ Daniel Youssef Bargieri, ${ }^{\mathrm{a}, \mathrm{b}}$ \\ Irene Silva Soares, ${ }^{d}$ Cibele Aparecida Tararam, ${ }^{a, b}$ Mauricio M. Rodrigues ${ }^{a, b}$ \\ Centro Terapia Celular e Molecular (CTCMol), Universidade Federal de São Paulo, Escola Paulista de Medicina, São Paulo, Brazila; Departamento de Microbiologia, \\ Imunologia e Parasitologia, Universidade Federal de São Paulo, Escola Paulista de Medicina, São Paulo, Brazil'b; Departamento de Imunologia, Instituto de Ciência \\ Biomédicas, Universidade de São Paulo, Cidade Universitária, São Paulo, Brazil`; Departamento de Análises Clínicas e Toxicológicas, Faculdade de Ciências Farmacêuticas, \\ Universidade de São Paulo, Cidade Universitária, São Paulo, Brazil ${ }^{\text { }}$
}

A Plasmodium falciparum circumsporozoite protein (CSP)-based recombinant fusion vaccine is the first malaria vaccine to reach phase III clinical trials. Resistance to infection correlated with the production of antibodies to the immunodominant central repeat region of the CSP. In contrast to $P$. falciparum, vaccine development against the CSP of Plasmodium vivax malaria is far behind. Based on this gap in our knowledge, we generated a recombinant chimeric protein containing the immunodominant central repeat regions of the $P$. vivax CSP fused to Salmonella enterica serovar Typhimurium-derived flagellin (FliC) to activate the innate immune system. The recombinant proteins that were generated contained repeat regions derived from each of the 3 different allelic variants of the $P$. vivax CSP or a fusion of regions derived from each of the 3 allelic forms. Mice were subcutaneously immunized with the fusion proteins alone or in combination with the Toll-like receptor 3 (TLR-3) agonist poly(I-C), and the anti-CSP serum IgG response was measured. Immunization with a mixture of the 3 recombinant proteins, each containing immunodominant epitopes derived from a single allelic variant, rather than a single recombinant protein carrying a fusion of regions derived from each of 3 allelic forms elicited a stronger immune response. This response was independent of TLR-4 but required TLR-5/MyD88 activation. Antibody titers significantly increased when poly $(\mathrm{I} \cdot \mathrm{C})$ was used as an adjuvant with a mixture of the 3 recombinant proteins. These recombinant fusion proteins are novel candidates for the development of an effective malaria vaccine against $P$. vivax.

or the past 20 years, a Plasmodium falciparum circumsporozoite protein (CSP)-based recombinant malaria vaccine has been at the forefront of malaria vaccine research (reviewed in reference 1). This vaccine comprises a recombinant fusion protein of the C-terminal portion of the P. falciparum CSP (RT) and the hepatitis B surface antigen (S). The fusion protein (RTS) when expressed together with the hepatitis B antigen (S) in Saccharomyces cerevisiae naturally assembles into a virus-like particle termed RTS,S. This particle is part of the vaccine formulation RTS,S/ AS01E that also includes monophosphoryl lipid A and QS21 in a liposomal suspension (1).

This vaccine formulation is the first of the malaria vaccines to reach phase III clinical trials. The vaccination efficiency, which was measured for 14 months after the administration of the first dose, was $50.4 \%$, and it was determined by examining the retardation of the first clinical malaria episode in 5- to 17-month-old African children (2). A parallel study in 6- to 12-week-old infants vaccinated with RTS,S/AS01E revealed a vaccine efficacy of $30.1 \%$ (3). In spite of the initial success in the 5- to 17-month-old children, the efficacy of RTS,S/AS01E declined to $16.8 \%$ over a 4 -year period (4).

An examination of the mechanism of vaccine action revealed that an increase in anti-CSP antibody titers correlated with protection against clinical malaria episodes (5). This field observation is in agreement with the results obtained from the phase IIb clinical trials in adults, which showed that anti-CSP antibodies played a prominent role in conferring resistance to malaria challenge (6). These putative protective antibodies mainly target the immunodominant repeat region of the P. falciparum CSP (6).
There still remains a tremendous need to develop new malaria vaccine candidates, especially those targeting Plasmodium vivax, the second-most-prevalent cause of malaria worldwide (7). On the basis of the results obtained with the P. falciparum CSP-derived vaccine, we generated recombinant polypeptides containing various immunodominant regions of the $P$. vivax CSP fused with a strong agonist of the innate immune system, the flagellin (FliC) protein of Salmonella enterica serovar Typhimurium. The enhanced immunogenicity of FliC-containing fusion proteins has been previously demonstrated in studies of $P$. vivax and $P$. falciparum merozoite-derived vaccines (8-10).

In contrast to the $P$. falciparum CSP, 3 different allelic forms of the $P$. vivax CSP have been identified to date. The 2 most common alleles are VK210 and VK247 (11, 12). A third allelic form (called $P$. vivax-like) may exist but is still a matter of debate. Several reports have described the existence of this allelic form in different parts of the world (13-16). However, one study that analyzed 126 samples from $P$. vivax-infected individuals from Central America, South America, Africa, southeast Asia, and India failed to detect

Received 13 May 2013 Returned for modification 13 June 2013 Accepted 8 July 2013

Published ahead of print 17 July 2013

Address correspondence to Mauricio M. Rodrigues, mrodrigues@unifesp.br. M.T.A.L. and A.G.A.C. contributed equally to this work.

Copyright $\odot$ 2013, American Society for Microbiology. All Rights Reserved. doi:10.1128/CVI.00312-13 
this allelic form of the CSP (17). The variations between the allelic forms mainly occur in the central immunodominant repeat region. Distinct nonapeptides have been identified for each of the allelic forms, GDRA(D/A)GQPA in the VK210 CSP, ANGA(G/ D) (N/D)QPG in the VK247 CSP, and APGANQ(E/G)GAA in the $P$. vivax-like CSP. The existence of 3 allelic forms requires a vaccine to elicit antibodies against all 3 immunodominant epitopes of the $P$. vivax CSP in order to have universal coverage. To achieve this, 2 approaches were used in this study. The first approach involved mixing 3 recombinant fusion proteins, each of which expressed 1 of the 3 allelic forms. Alternatively, a single recombinant fusion protein that contained representative epitopes from the 3 allelic forms (All-CS-epitopes) was generated. The immunogenicity of the recombinant fusion proteins was assessed by immunizing mice with the recombinant proteins individually, the mixture of the 3 allelic forms, or the protein containing a fusion of all 3 immunodominant epitopes (All-CS-epitopes). The serum IgG immune response was compared following the immunization of mice with each of the different preparations, given alone or in combination with an adjuvant, the TLR-3 agonist poly(I.C).

\section{MATERIALS AND METHODS}

Ethics statement. This study was carried out in strict accordance with the recommendations provided by the Guide for the Care and Use of Laboratory Animals of the Brazilian National Council of Animal Experimentation (http://www.cobea.org.br/). The protocol was approved by the Committee on the Ethics of Animal Experiments of the Institutional Animal Care and Use Committee at the Federal University of São Paulo (no. CEP 0426/09).

Mice. Wild-type (WT) female 6- to 8-week-old C57BL/6 ( $\left.\mathrm{H} 2^{\mathrm{b}}\right)$ mice and age- and sex-matched TLR-4, TLR-5, or MyD88 knockout (KO) (1820) mice were purchased from the Center for Development of Experimental Models (CEDEME), Federal University of São Paulo, Brazil.

Generation of recombinant fusion proteins. Details on the generation of the His-FliC-VK210 fusion protein have been previously described (21). To generate the other recombinant fusion proteins, we followed the same strategy, using the following recombinant gene sequences: for VK247, 5'-CAAGCTTGCGCCAGCGATATGGCGAAAAAAGAAACC GTGTGGCGTCTGGAAGAATTTGGCCGCTTCGCAAACGGTGCAG GTAATCAGCCGGGTGCCAATGGCGCCGGTAATCAGCCGGGTGC GAATGGCGCGGGTAATCAGCCGGGTGCTAATGGCGCTGGTAAT CAGCCGGGTGCAAATGGCGCAGGCAACCAGCCGGGTGCCAATG GTGCCGGCAATCAGCCGGGTGCCAACGGCGCAGGCAATCAACC GGGTGCCAATGGCGCAGGCAATCAGCCGGGTTAACTCGAG-3'; for $P$. vivax-like, 5'-CAAGCTTGCGCCAGCGATATGGCGAAAAAAG AAACCGTGTGGCGTCTGGAAGAATTTGGCCGCTTCGCACCGGG TGCGAACCAGGAAGGCGGTGCAGCAGCACCGGGTGCGAATCAG GAAGGCGGTGCGGCCGCACCGGGTGCCAATCAAGAAGGCGGTG CCGCCGCACCGGGTGCAAATCAAGAAGGCGGTGCGGCAGCCCC GGGCGCCAATCAGGAAGGCGGTGCCGCCGCCCCGGGTGCTAAC CAAGAAGGCGGTGCTGCGGCCCCGGGCGCCAACCAAGAAGGCG GTGCCGCGGCCCCGGGCGCTAACCAGGAAGGCGGTGCCGCGTA ACTCGAG-3'; and for All-CS-epitopes, 5' -CAAGCTTGCGCAAGCGA TATGGCGAAAAAAGAAACCGTGTGGCGTCTGGAAGAATTTGGCC GTTTCGATCGTGCAGATGGTCAGCCGGCAGGTGACCGCGCCGA CGGTCAGCCGGCAGGTGATCGTGCAGCCGGTCAGCCGGCCGGT GATCGTGCAGCGGGCCAGCCGGCGGGTGATCGCGCCGATGGTC AACCGGCGGGTGATGCAAACGGTGCAGGTAATCAGCCGGGCGC CAATGGCGCAGGTAATCAGCCGGGTGCCAATGGTGCCGGCAAT CAGCCGGGCGCCAACGGCGCCGGTAATCAGCCGGGTGCACCGG GTGCAAACCAGGAAGGCGGTGCAGCAGCACCGGGTGCAAATCA AGAAGGCGGTGCCGCAGCCCCGGGCGCCAATCAAGAAGGCGGT GCGGCCGCCCCGGGTGCAAATCAGGAAGGCGGTGCCGCCTAA CTCGAG-3'. The regions in bold type represent the target sites for
HindIII and XhoI. The recombinant protein was expressed and purified as previously described $(8,21)$. Protein concentrations were determined by the Bradford assay and SDS-PAGE analysis.

FliC purification. Native Salmonella Typhimurium FliC was purified from the attenuated Salmonella Typhimurium SL3201 strain, which expresses FliC but not FljB (8). The purity of the preparations was verified by SDS-PAGE.

Immunization regimen. Mice were subcutaneously (s.c.) immunized thrice with 1 or $10 \mu \mathrm{g}$ of the fusion protein or the purified FliC, with immunizations being administered 3 weeks apart. In the first immunization, a final volume of $50 \mu \mathrm{l}$ was injected into each hind footpad, while for the second and third immunizations, a final volume of $100 \mu$ l was injected at the base of the tail. In some experiments, the recombinant fusion proteins were administered with an adjuvant. The TLR-3 agonist poly(I.C) $(50 \mu \mathrm{g} /$ dose/mouse) (InvivoGen, San Diego, CA) or complete (CFA) or incomplete (IFA) Freund's adjuvant (Sigma-Aldrich Co., St. Louis, MO), administered as an emulsion $(1: 1[\mathrm{vol} / \mathrm{vol}])$ with the immunogen, were used.

Immunological assays. Serum anti- $P$. vivax CSP (PvCSP) antibodies were detected by enzyme-linked immunosorbent assay (ELISA) as described previously $(8,21)$. Briefly, the recombinant proteins hexahistidine $\left(\mathrm{His}_{6}\right)$-PvCSP-VK210, $\mathrm{His}_{6}$-PvCSP-VK247, and $\mathrm{His}_{6}$-PvCSP-P. vivaxlike (100 to $400 \mathrm{ng} /$ well) were employed as capture agents. A detailed description of these proteins, which contain the entire PvCSP protein, including the $\mathrm{N}$ - and C-terminal portions and the repeats (VK210, VK247, or P. vivax-like), will be published elsewhere. Serum samples from immunized and nonimmunized mice were tested at serial dilutions from $1: 200$ to $1: 819,200$. A peroxidase-conjugated goat anti-mouse IgG (Sigma-Aldrich Co.) was used as the detection antibody at a final dilution of 1:1,000. The highest dilution yielding an optical density at $492 \mathrm{~nm}$ $\left(\mathrm{OD}_{492}\right)$ of $>0.1$ was considered the anti-PvCSP antibody titer. We performed, in parallel, a standard curve of purified mouse IgG (Sigma) using the capture anti-Fab (fragment, antigen binding) antibody (Sigma) according to the protocol suggested in reference 22. According to our standard curve of mouse IgG titers, antibody titers of $10^{4}$ represent $\sim 5 \mu \mathrm{g} / \mathrm{ml}$ of specific IgG. The results are presented as means \pm the standard deviation (SD).

Statistical analyses. One-way analysis of variance (ANOVA), the Student $t$ test, the Tukey honestly significant difference (HSD) test, and the Kruskal-Wallis one-way analysis of variance were used to compare the differences between the mean values of the antibody titers in the immunization groups. Differences were considered significant when the $P$ value was $<0.05$.

\section{RESULTS}

Recombinant flagellin fusion proteins. We generated 3 recombinant fusion proteins containing a hexahistidine tag $\left(\mathrm{His}_{6}\right)$ and the allelic variants of the CSP immunodominant regions (VK210, VK247, or P. vivax-like) fused to the C-terminal end of FliC. In addition, we generated a fourth recombinant protein expressing all 3 CSP immunodominant regions as a fusion polypeptide linked to the C-terminal end of FliC (schematically represented in Fig. 1). This recombinant protein contained fewer repeats of each allelic form of the CSP due to the constraint of the number of amino acids that we can add to the C-terminal region. We observed that recombinant proteins with larger amino acid insertions were not stable (M. T. A. Leal and M. M. Rodrigues, unpublished data).

Under denaturing (reducing) conditions, the purified proteins yielded 2 bands, a predominant band of $\sim 60$ to $70 \mathrm{kDa}$ and a larger band of $\sim 130 \mathrm{kDa}$ (Fig. $2 \mathrm{~A}$ ). The recombinant protein in the bands was identified using a monoclonal antibody (MAb) to the $\mathrm{His}_{6}$ tag (Fig. 2B). The larger band most likely represents a dimer of the recombinant protein, which remains in this form even under denaturing conditions. 
Histidine tag (6aa)

FliC (490 aa)

P. vivax immundominant $\mathrm{CS}$ epitopes

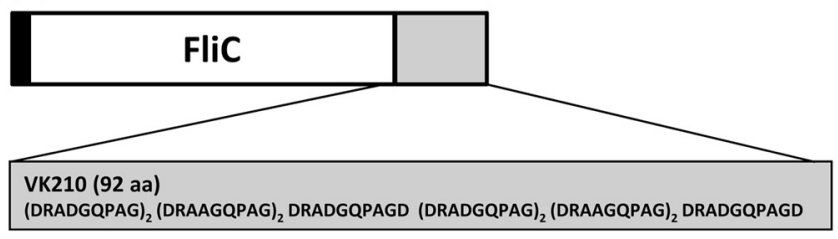

VK247 (72 aa) $=\left(\right.$ (ANGAGNQPG $_{8}$

P. vivax-like $(88 \mathrm{aa})=(\text { APGANQEGGAA })_{8}$

All-CS-epitopes $(126$ aa $)=$

(DRADGQPAG) ${ }_{2}$ (DRAAGQPAG) ${ }_{2}$ DRADGQPAGD (ANGAGNQPG) ${ }_{4}$ (APGANQEGGAA)

FIG 1 Schematic representation of the recombinant proteins used in the present study.

In previous studies, we determined that the fusion polypeptide $\mathrm{His}_{6}$-FliC-VK210 retained the ability to be recognized by MAb (2F2) specific for the immunodominant VK210 epitope $(21,23)$. ELISA and an immunoblot assay performed with MAb (2F2) showed that this epitope is available for immune recognition in the fusion protein $\mathrm{His}_{6}$-FliC-All-CS-epitope (data not shown). The anti-Vk247 MAb (2E10.E9) (A. Cochrane, unpublished data) recognized the $\mathrm{His}_{6}$-FliC-VK247 and $\mathrm{His}_{6}$-FliC-All-CS-epitope recombinant proteins (Fig. 2C).

CSP-specific antibody responses in mice immunized with the recombinant fusion proteins. The anti-CSP serum IgG response was determined in 6 groups of C57BL/ 6 mice immunized with either the purified fusion proteins or native FliC. Each mouse received $10 \mu \mathrm{g}$ of protein per immunization, in the absence of any adjuvants. The vaccination timeline is depicted in Fig. 3A.

Mice immunized with the recombinant proteins $\mathrm{His}_{6}$-FliCVK210 (G2), His $_{6}$-FliC-VK247 (G3), or His ${ }_{6}$-FliC-P. vivax-like (G4) developed significant anti-PvCSP IgG titers, with the antibodies recognizing the homologous allelic forms (Fig. 3B, C, and D). After 2 or 3 immunizations, the antibody titers to the CSP allelic variants VK210 and VK247 were in the range of $10^{4}$ (equivalent to $5 \mu \mathrm{g} / \mathrm{ml}$ of specific IgG). In contrast, the antibody titers to the $P$. vivax-like CSP allelic form were significantly higher (in the range of $10^{5}$ ) (Fig. 3D).

The sera of mice immunized with the individual proteins (G2, $\mathrm{G} 3$, and G4) were tested for the presence of cross-reactive antibodies using the $\mathrm{His}_{6}$-PvCSP-VK210, His $_{6}$-PvCSP-VK247, or $\mathrm{His}_{6}$-PvCSP-P. vivax-like protein on the plates. We found that mice immunized with $\mathrm{His}_{6}$-FliC-VK247 (G3) or $\mathrm{His}_{6}$-FliC-P. vivax-like (G4) developed cross-reactive anti-PvCSP IgG titers to $\mathrm{His}_{6}$-PvCSP-VK210. However, these titers were significantly lower than those of mice immunized with G2 $(P<0.01$ in both cases, data not shown). In addition, mice immunized with $\mathrm{His}_{6}{ }^{-}$ FliC-VK210 (G2) or His $_{6}$-FliC-P. vivax-like (G4) developed negligible IgG titers to $\mathrm{His}_{6}$-PvCSP-VK247 (data not shown). Finally, mice immunized with $\mathrm{His}_{6}$-FliC-VK210 (G2) or $\mathrm{His}_{6}$-FliCVK247 (G3) failed to generate IgG titers to the $\mathrm{His}_{6}$-PvCS-P. vivax-like protein (data not shown). We concluded that the cross-

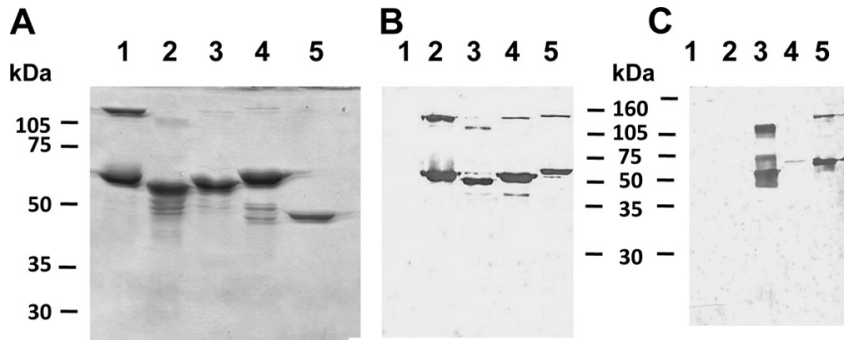

FIG 2 SDS-PAGE of the recombinant proteins. (A) Each lane was loaded with approximately $1 \mu \mathrm{g}$ of protein, separated by $15 \%$ SDS-PAGE, and stained with Coomassie blue. Lane 1, $\mathrm{His}_{6}$-FliC-VK210; lane 2, $\mathrm{His}_{6}$-FliC-VK247; lane 3, $\mathrm{His}_{6}$ FliC-P. vivax-like; lane 4, $\mathrm{His}_{6}$-FliC-All-CS-epitopes; lane 5, native FliC. (B) Recombinant proteins separated by SDS-PAGE were probed with an anti-His ${ }_{6} \mathrm{MAb}$. Lane 1, native FliC; lane 2, $\mathrm{His}_{6}$-FliC-VK210; lane 3, $\mathrm{His}_{6}$-FliC-VK247; lane 4, His $_{6}$-FliC-P. vivax-like; lane 5, His $_{6}$-FliC-All-CS-epitopes. (C) Recombinant proteins separated by SDS-PAGE were probed with an MAb against the VK247 CSP. Lanes 1 to 5 contain the same samples as those described in panel B.

reactive IgG antibodies are very limited and it is not possible to use a single variant as a universal vaccine.

Mice immunized with the mixture of $\mathrm{His}_{6}$-FliC-VK210, His $_{6}$ FliC-VK247, and $\mathrm{His}_{6}$-FliC-P. vivax-like (G5) proteins produced immune responses targeting all 3 allelic forms. The immune response in mice injected with this mixture was as high as or slightly lower than (Fig. 3B, C, and D) that in mice receiving single-fusionprotein immunizations. In one case only (VK210), there was a statistically significant difference between groups 2 and $5(P<$ 0.05, one-way ANOVA). In contrast, mice immunized with the recombinant fusion protein $\mathrm{His}_{6}$-FliC-All-CS-epitopes (G6) failed to generate a significant antibody response to the VK210 or VK247 CSP variants (Fig. 3B and C). Hence, we concluded that immunization with a mixture of the 3 different allelic forms is the most suitable strategy to elicit an effective immune response.

To understand the nature of the humoral immune response, we examined the subclass distribution of IgG anti-CSP response in mice from groups 2, 3, and 4. All mice immunized with the recombinant fusion proteins developed higher IgG1 levels, with IgG1/IgG2c ratios ranging from 10.66 to 512 (Fig. 4).

The PvCSP-specific antibody response in mice immunized with His $_{6}$-FliC-PvCS-VK210 is dependent on TLR-5 and MyD88 activation. The innate immune agonist FliC activates different pattern recognition receptors (24-26). In our study, we investigated the activation of TLR-4, TLR-5, and MyD88 by immunizing wild-type (WT), as well as TLR-4, TLR-5, and MyD88 KO mice with $\mathrm{His}_{6}$-FliC-VK210. We estimated the serum antibody titers in these animals after each immunization. The antibody titers in TLR-5 or MyD88 KO mice were significantly lower than those in WT mice (Fig. 5). In contrast, TLR-4 KO mice mounted a humoral immune response similar to that observed in WT mice. These results demonstrated that TLR-5 and MyD88 but not TLR- 4 signaling were required for the immunogenicity of the recombinant fusion proteins. In addition to the antibody titers, we estimated the IgG1/IgG2c ratio in these animals. We found that in WT, TLR-5, MyD88, or TLR-4-KO mice, the ratios were 217.6, $38.4,65.6$, and 64, respectively (data not shown).

Use of poly $(\mathrm{I} \cdot \mathrm{C})$ as an adjuvant improved antibody response to the admixed proteins. To increase the antibody titers to all 3 allelic variants of CSP, we employed new vaccine formulations that contained a mixture of the recombinant fusion protein and a 

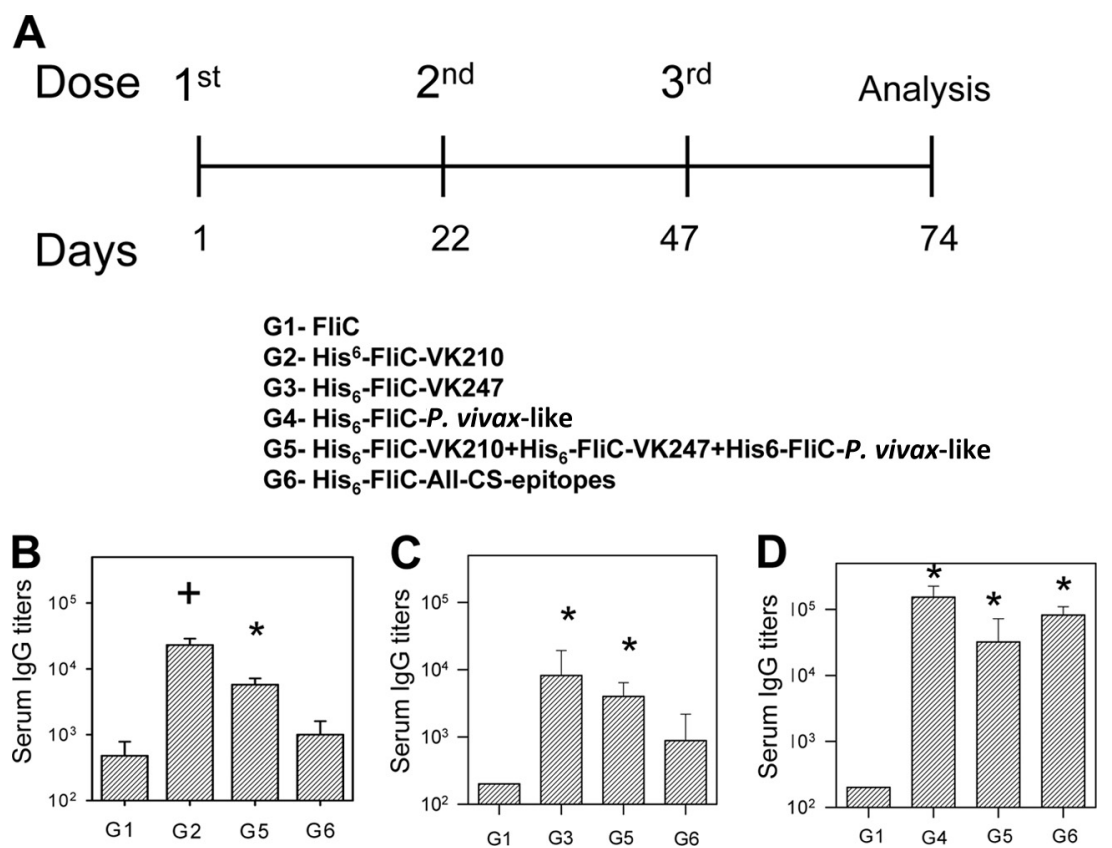

FIG 3 Immunogenicity of recombinant fusion proteins. (A) C57BL/6 mice $(n=6)$ were immunized s.c. with 3 doses $(10 \mu \mathrm{g} /$ animal/dose) of the indicated proteins (G1 to G6) at the indicated times. The serum antibody levels measured 74 days after the administration of the first dose were determined by ELISA using plates coated with the capture agents $\mathrm{His}_{6}-\mathrm{PvCSP}-\mathrm{VK} 210$ (B), His ${ }_{6}-\mathrm{PvCSP}-\mathrm{VK} 247$ (C), and His 6 -PvCSP-P. vivax-like (D). The results are expressed as means \pm SD. ${ }^{*}$, the values are significantly higher than those in controls immunized with FliC alone $(\mathrm{G} 1)(P<0.05$, one-way ANOVA). + , the value of G2 is significantly higher than those of all other groups (G1, G5, and G6) $(P<0.05$, one-way ANOVA).

strong adjuvant. Initially, mice were immunized with the recombinant fusion protein $\mathrm{His}_{6}$-FliC-All-CS-epitopes alone or in combination with either CFA/IFA or poly $(\mathrm{I} \cdot \mathrm{C})$. Following the administration of 3 doses, we found that the antibody titers to all 3 allelic forms were similar, regardless of whether the protein was used alone or in combination with either adjuvant (Fig. 6).

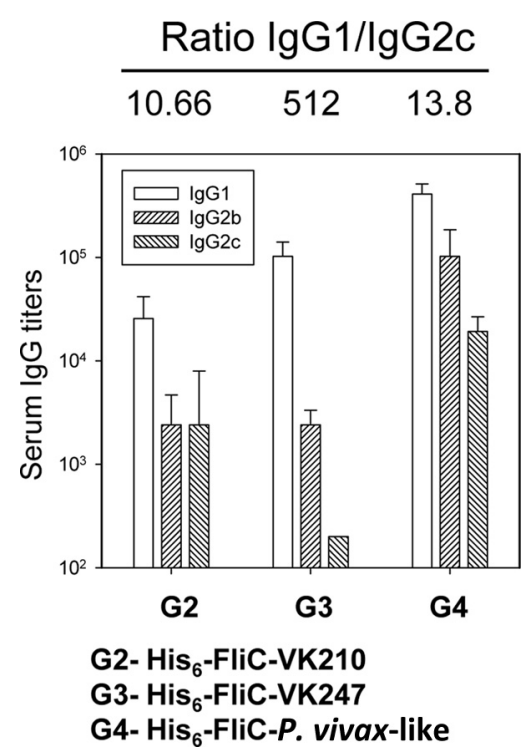

FIG 4 Determination of IgG subclasses in C57BL/6 mice $(n=4)$ immunized with 3 doses of the indicated proteins. The serum antibody titers, measured 74 days after the first dose, were determined by ELISA using plates coated with the proteins representing the homologous alleles ( $\mathrm{His}_{6}-\mathrm{PvCSP}-\mathrm{VK} 210$ [G2], $\mathrm{His}_{6}$ PvCSP-VK247 [G3], or His $_{6}$-PvCSP-P. vivax-like [G4] protein). The results are expressed as means \pm SD.
Subsequently, mice were immunized with the mixture of recombinant fusion proteins either alone or in combination with poly (I.C). After the second dose, the antibody titers to all 3 different allelic forms of CSP were higher in mice immunized with the protein mixture in combination with poly $(\mathrm{I} \cdot \mathrm{C})$ than in mice im-
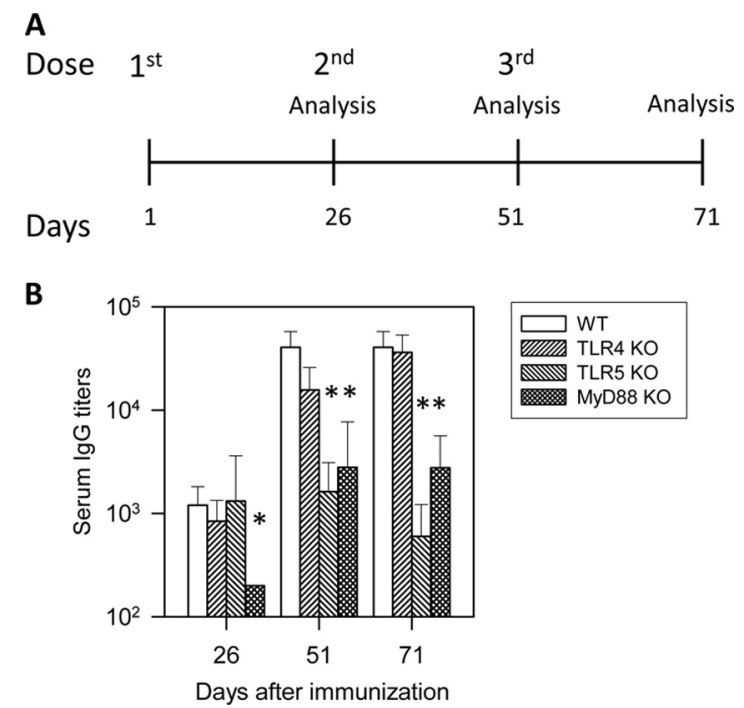

FIG 5 TLR-5/MyD88 dependence of the serum IgG response in mice immunized with the recombinant fusion protein $\mathrm{His}_{6}$-FliC-VK210. (A) C57BL/6 mice $(n=6)$ were immunized s.c. with 3 doses ( $10 \mu \mathrm{g} / \mathrm{animal} / \mathrm{dose})$ of recombinant protein at the indicated time points. Serum samples were collected at the indicated time points following the first dose, and serum antibody titers were determined by ELISA by using plates coated with $\mathrm{His}_{6}{ }_{6}$-PvCSP-VK210. (B) The results are expressed as means $\pm \mathrm{SD}$. ${ }^{*}$, the values are significantly lower in TLR-5 or MyD88 KO mice than in immunized WT controls $(P<0.001)$. 
A

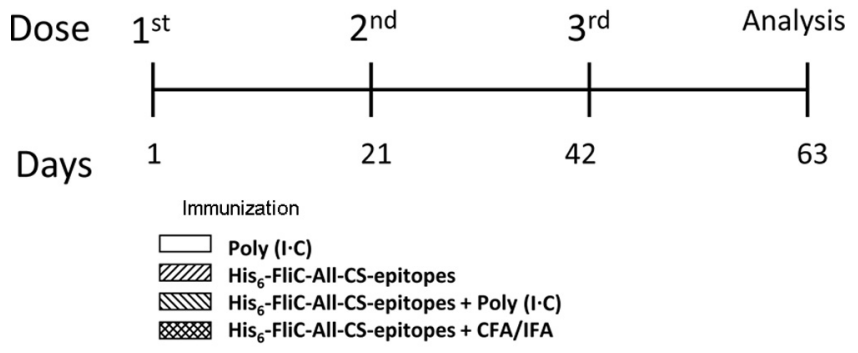

B

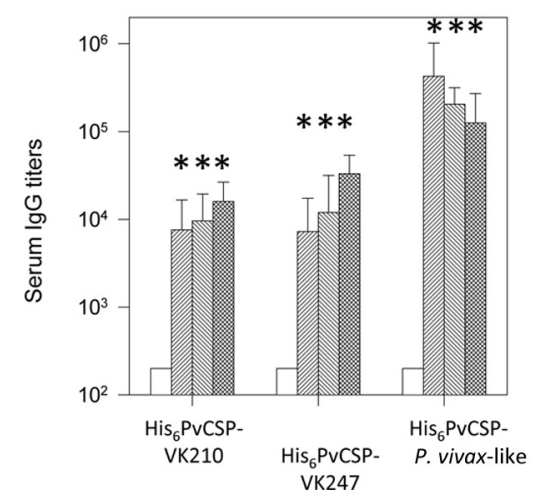

FIG 6 Presence of strong adjuvants did not increase the immunogenicity of the recombinant fusion protein $\mathrm{His}_{6}$-FliC-All-CS-epitopes. (A) C57BL/6 mice $(n=6)$ were immunized s.c. with 3 doses $(10 \mu \mathrm{g} / \mathrm{animal} / \mathrm{dose})$ of recombinant protein according to the timeline in the presence or absence of the indicated adjuvants. The serum antibody titer, 53 days after administration of the first dose, was quantified by ELISA by using plates coated with $\mathrm{His}_{6}$-PvCSP-VK210, $\mathrm{His}_{6}$-PvCSP-VK247, or $\mathrm{His}_{6}$-PvCSP-P. vivax-like proteins. (B) Results are expressed as means $\pm \mathrm{SD} .{ }^{*}$, the values are significantly higher than those in controls injected with only poly (I.C) $(P<0.001$, one-way ANOVA). No statistically significant differences were found when we compared the three formulations used with or without adjuvants (one-way ANOVA).

munized with the recombinant proteins alone (Fig. 7B, C, and D). The increase in IgG titers persisted for 180 days after the first immunization (138 days after the last dose). The IgG1/IgG2c ratios in mice immunized with the recombinant fusion protein mixture in the presence of poly $(\mathrm{I} \cdot \mathrm{C})$ were $0.4\left(\mathrm{His}_{6}\right.$-PvCSP-VK210), 1.4 ( His $_{6}-\mathrm{PvCSP}-\mathrm{VK} 247$ ), and 0.8 ( $\mathrm{His}_{6}$-PvCSP-P. vivax-like) (data not shown). In contrast, for the animals immunized with the recombinant proteins in the absence of poly(I.C), the IgG1/IgG2c ratios were 129 ( $\mathrm{His}_{6}$-PvCSP-VK210), 78 ( $\mathrm{His}_{6}$-PvCSP-VK247), and 69 (His $_{6}$-PvCSP-P. vivax-like) (data not shown). These results indicate that the immunogenicity of the recombinant fusion protein mixture can be improved by coimmunization with the TLR-3 agonist poly(I.C). Furthermore, we observed that these mice developed a balanced IgG1/IgG2c immune response in the presence of this adjuvant, and this finding was very much in contrast to that observed when the proteins were administered alone (Fig. 4).

\section{DISCUSSION}

In the present study, we evaluated the immunogenicity of recombinant proteins consisting of the immunodominant epitope of $P$. vivax sporozoites fused to an innate immune agonist, Salmonella Typhimurium-derived FliC. Using a mixture of 3 recombinant proteins, IgG antibody responses to all 3 P. vivax CSP allelic forms were successfully elicited in mice. The immune response was specific and long lasting. These are characteristics of T-cell-depen- dent antibody responses. However, we did not specifically investigate whether $\mathrm{T}$ cells were required. The antibody titers to the 3 CSP allelic variants might be further increased by coimmunization with the TLR-3 agonist, poly $(\mathrm{I} \cdot \mathrm{C})$.

When the effectiveness of the different strategies was compared, immunization with the mixture of the 3 recombinant proteins was found to be superior to immunization with a fusion protein ( $\mathrm{His}_{6}$-FliC-All-CS-epitopes) containing the epitopes derived from all 3 allelic variants. Mice immunized with the $\mathrm{His}_{6}{ }^{-}$ FliC-All-CS-epitopes recombinant protein developed high antibody titers against the allelic variant $P$. vivax-like but mounted significantly lower responses against the VK210 and VK247 allelic variants. Importantly, the immune response to this recombinant protein was not improved by coadministration of an immune adjuvant, poly(I.C). The precise reason why this adjuvant did not improve the antibody response is not clear. However, it does not exclude the possibility that better results can be obtained using other adjuvant formulations.

On the other hand, high titers of antibodies recognizing all $3 P$. vivax CSP allelic variants could be elicited by immunization of mice with a mixture of the 3 recombinant proteins. Furthermore, this humoral response could be improved and balanced by coadministration of the TLR-3 agonist poly $(\mathrm{I} \cdot \mathrm{C})$. The use of poly $(\mathrm{I} \cdot \mathrm{C})$ as an adjuvant is being clinically tested in humans (27).

Flagellins as carriers/adjuvants in recombinant protein constructs have been tested in different systems (reviewed in reference 28). Two of these recombinant fusion proteins, VAX125 and VAX128, consisting of influenza epitope-flagellin fusions, have been successfully used during phase I clinical trials. VAX125 and VAX128C were generally well tolerated and were immunogenic in naive individuals. A large fraction of the vaccinated individuals developed titers of neutralizing antibodies, which is consistent with seroprotection $(28,29)$. These findings suggest that these vaccine formulations may confer a degree of protection during pandemic influenza.

While we used FliC, the studies described above used FlijB flagellin. The difference between them is restricted to the hypervariable domain. No formal comparison of both proteins as an adjuvant/carrier has been published to date. However, a comparison made in the mouse model yielded comparable results (L. C. S. Ferreira, unpublished data).

Similar to VAX125 and VAX128C, our recombinant fusion proteins were immunogenic even in the absence of conventional adjuvants. We found that the main adjuvant activity was mediated by the ability of FliC to activate the TLR-5/MyD88 pathway, as TLR-5 and MyD88 KO mice each displayed a significantly impaired immune response after vaccination. A contribution of contaminating bacterial lipopolysaccharide (LPS) to the observed immunogenicity of our formulations seems unlikely, considering that the response in TLR-4 KO mice was similar to that in WT mice.

The importance of antibodies targeted to the repeat domain of CSP for immunity against the malaria sporozoites has been known for a long time. The first MAbs specific to the CSP of Plasmodium berghei passively transferred protection against the experimental infection (30). These initial findings have been reproduced in several species of Plasmodium, including $P$. vivax (31). More-recent studies of phase I or II clinical assays of immunization with the RTS,S/AS01E vaccine demonstrated a strong 

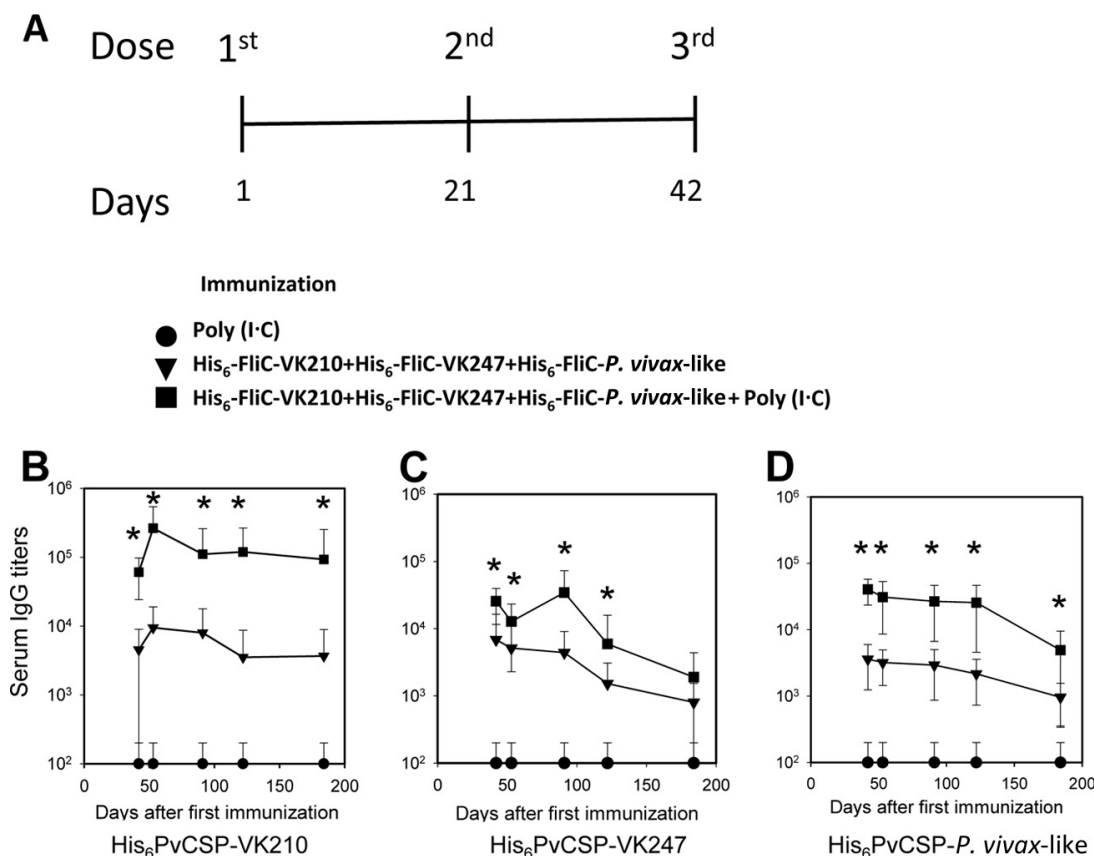

FIG 7 Kinetics of the IgG immune response in C57BL/6 mice immunized with a mixture of 3 recombinant fusion proteins administered with or without the TLR-3 agonist poly(I.C). (A) Groups of mice $(n=6)$ were immunized s.c. with 3 doses $(1 \mu \mathrm{g} / \mathrm{animal} / \mathrm{dose})$ of a mixture of recombinant proteins at the indicated time points in the presence or absence of the indicated adjuvants. Serum samples were collected at different time points until day 184 following the first dose, and

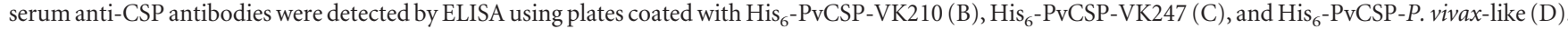
The results are expressed as means $\pm \mathrm{SD} .{ }^{*}$, the values are significantly higher in mice immunized with recombinant protein mixture in the presence of poly(I-C) than in mice injected with the mixture alone $(P<0.05$ in all cases $)$.

correlation between protective immunity and the presence of antibodies to the repeat domain of the $P$. falciparum $\operatorname{CSP}(5,6)$.

Although we have clearly demonstrated the presence of $P$. vivax CSP-specific antibodies targeting the repeat domain of the different allelic variants, their function remains elusive. Preliminary immunofluorescence analyses of the VK210 and VK247 strains showed that these antibodies recognized $P$. vivax sporozoites. However, detailed analyses need to be performed. Moreover, the ability of these antibodies to neutralize sporozoites in vitro has yet to be evaluated.

In contrast to $P$. falciparum, the development of a vaccine against the preerythrocytic forms of $P$. vivax has been limited to preclinical immunization models developed mostly in mice. A single phase I clinical trial has been performed. Studies in mice and a nonhuman primate examined the recombinant VMP001 protein generated in Escherichia coli. This protein contains repeat regions derived from the VK210 allelic variant of the $P$. vivax CSP. A repeat sequence derived from the VK247 allele was also introduced into the C-terminal region. This protein has been shown to be immunogenic in different vaccine formulations and is capable of inducing an immune response mediated by antibodies and $\mathrm{CD}^{+}{ }^{+} \mathrm{T}$ cells (32-36). The specificities of the antibodies induced by the vaccine VMP001 were not investigated by binding inhibition experiments. While in our case the immune responses are focused on the repeat region, animals immunized with VMP001 reacted strongly with the $\mathrm{C}$-terminal region $(32,36)$. Interestingly, VMP001 induced partial cross-protective immunity in mice challenged with $P$. berghei sporozoites (37). The region(s) of the PvCSP that elicited this cross-protective immune response remains unknown.
Studies performed in parallel used long recombinant $P$. vivax CSP-derived peptides to develop a synthetic malaria vaccine (38). Peptides representing CSP N- or C-terminal portions or the amino acid repetitions (allele VK210) have been tested in phase I clinical trials. This vaccine formulation, which contains the adjuvant Montanide ISA 720, was safe and well tolerated following administration by the intramuscular route. Vaccinated individuals developed antibodies that targeted 3 different epitopes of the $P$. vivax CSP, and gamma interferon (IFN- $\gamma$ )-producing cells were observed (39).

In summary, our findings extend the understanding of the use of Salmonella flagellin as an adjuvant and antigen carrier in vaccine formulations in general. More specifically, we generated recombinant fusion proteins consisting of fusions of different $P$. vivax CSP allelic variants with flagellin and showed that a formulation consisting of the mixture of these 3 allelic variant-flagellin fusions, administered in the presence of the adjuvant poly $(\mathrm{I} \cdot \mathrm{C})$, is sufficient to induce strong and long-lasting anti-CSP immunity in mice. As both flagellin and poly $(\mathrm{I} \cdot \mathrm{C})$ have been considered to be promising adjuvants in human trials, this formulation might be a potentially new $P$. vivax vaccine candidate with broad coverage.

\section{ACKNOWLEDGMENTS}

This work was supported by grants from the FAPESP (no. 2009/15132-4), PNPD/CAPES, and INCTV-CNPq (to M.M.R. and I.S.S.) and fellowships from the CNPq (to M.M.R., I.S.S., and A.G.C.), FAPESP (to M.T.A.L., D.Y.B., and C.A.T.), and CAPES (to L.H.T.).

We thank Vander O. Jampaulo and Alba M. Gimenez for helping with the last few experiments. We also thank L. C. S. Ferreira from the University of São Paulo for sharing unpublished data with us. 


\section{REFERENCES}

1. Cohen J, Nussenzweig V, Nussenzweig R, Vekemans J, Leach A. 2010. From the circumsporozoite protein to the RTS, S/AS candidate vaccine. Hum. Vaccin. 6:90-96.

2. Agnandji ST, Lell B, Soulanoudjingar SS, Fernandes JF, Abossolo BP, Conzelmann C, Methogo BG, Doucka Y, Flamen A, Mordmüller B, Issifou S, Kremsner PG, Sacarlal J, Aide P, Lanaspa M, Aponte JJ, Nhamuave A, Quelhas D, Bassat Q, Mandjate S, Macete E, Alonso P, Abdulla S, Salim N, Juma O, Shomari M, Shubis K, Machera F, Hamad AS, Minja R, Mtoro A, Sykes A, Ahmed S, Urassa AM, Ali AM, Mwangoka G, Tanner M, Tinto H, D'Alessandro U, Sorgho H, Valea I, Tahita MC, Kaboré W, Ouédraogo S, Sandrine Y, Guiguemdé RT, Ouédraogo JB, Hamel MJ, Kariuki S, Odero C, et al. 2011. First results of phase 3 trial of RTS,S/AS01 malaria vaccine in African children. N. Engl. J. Med. 365:1863-1875.

3. Agnandji ST, Lell B, Fernandes JF, Abossolo BP, Methogo BGNO, Kabwende AL, Adegnika AA, Mordmüller B, Issifou S, Kremsner PG, Sacarlal J, Aide P, Lanaspa M, Aponte JJ, Machevo S, Acacio S, Bulo H, Sigauque B, Macete E, Alonso P, Abdulla S, Salim N, Minja R, Mpina M, Ahmed S, Ali AM, Mtoro AT, Hamad AS, Mutani P, Tanner M, Tinto H, D'Alessandro U, Sorgho H, Valea I, Bihoun B, Guiraud I, Kaboré B, Sombié O, Guiguemdé RT, Ouédraogo JB, Hamel MJ, Kariuki S, Oneko M, Odero C, Otieno K, Awino N, McMorrow M, Muturi-Kioi V, Laserson KF, Slutsker L, et al. 2012. A phase 3 trial of RTS,S/AS01 malaria vaccine in African infants. N. Engl. J. Med. 367:22842295.

4. Olotu A, Lusingu J, Leach A, Lievens M, Vekemans J, Msham S, Lang T, Gould J, Dubois MC, Jongert E, Vansadia P, Carter T, Njuguna P, Awuondo KO, Malabeja A, Abdul O, Gesase S, Mturi N, Drakeley CJ, Savarese B, Villafana T, Lapierre D, Ballou WR, Cohen J, Lemnge MM, Peshu N, Marsh K, Riley EM, von Seidlein L, Bejon P. 2011. Efficacy of RTS,S/AS01E malaria vaccine and exploratory analysis on anticircumsporozoite antibody titres and protection in children aged 5-17 months in Kenya and Tanzania: a randomised controlled trial. Lancet Infect. Dis. 11:102-109.

5. Olotu A, Fegan G, Wambua J, Nyangweso G, Awuondo KO, Leach A, Lievens M, Leboulleux D, Njuguna P, Peshu N, Marsh K, Bejon P. 2013. Four-year efficacy of RTS,S/AS01E and its interaction with malaria exposure. N. Engl. J. Med. 368:1111-1120.

6. Kester KE, Cummings JF, Ofori-Anyinam O, Ockenhouse CF, Krzych U, Moris P, Schwenk R, Nielsen RA, Debebe Z, Pinelis E, Juompan L, Williams J, Dowler M, Stewart VA, Wirtz RA, Dubois MC, Lievens M, Cohen J, Ballou WR, Heppner DG, Jr, RTS,S Vaccine Evaluation Group. 2009. Randomized, double-blind, phase 2a trial of falciparum malaria vaccines RTS,S/AS01B and RTS,S/AS02A in malaria-naive adults: safety, efficacy, and immunologic associates of protection. J. Infect. Dis. 200:337-346.

7. Guerra CA, Howes RE, Patil AP, Gething PW, Van Boeckel TP, Temperley WH, Kabaria CW, Tatem AJ, Manh BH, Elyazar IRF, Baird JK, Snow RW, Hay SI. 2010. The international limits and population at risk of Plasmodium vivax transmission in 2009. PLoS Negl. Trop. Dis. 4:774. doi:10.1371/journal.pntd.0000774.

8. Bargieri DY, Rosa DS, Braga CJ, Carvalho BO, Costa FT, Espíndola NM, Vaz AJ, Soares IS, Ferreira LC, Rodrigues MM. 2008. New malaria vaccine candidates based on the Plasmodium vivax merozoite surface protein-1 and the TLR-5 agonist Salmonella Typhimurium FliC flagellin. Vaccine 26:6132-6142.

9. Bargieri DY, Leite JA, Lopes SC, Sbrogio-Almeida ME, Braga CJ, Ferreira LC, Soares IS, Costa FT, Rodrigues MM. 2010. Immunogenic properties of a recombinant fusion protein containing the C-terminal 19 $\mathrm{kDa}$ of Plasmodium falciparum merozoite surface protein-1 and the innate immunity agonist FliC flagellin of Salmonella Typhimurium. Vaccine 28: $2818-2826$.

10. Bargieri DY, Soares IS, Costa FTM, Braga CJ, Ferreira LCS, Rodrigues MM. 2011. Malaria vaccine development: are bacterial flagellin fusion proteins the bridge between mouse and humans? J. Parasitol. Res. 2011: 965369.

11. Arnot DE, Barnwell JW, Tam JP, Nussenzweig V, Nussenzweig RS, Enea V. 1985. Circumsporozoite protein of Plasmodium vivax: gene cloning and characterization of the immunodominant epitope. Science 230: 815-818.

12. Rosenberg R, Wirtz RA, Lanar DE, Sattabongkot J, Hall T, Waters AP,
Prasittisuk C. 1989. Circumsporozoite protein heterogeneity in the human malaria parasite Plasmodium vivax. Science 245:973-976.

13. Qari SH, Shi YP, Povoa MM, Alpers MP, Deloron P, Murphy GS, Harjosuwarno S, Lal AA. 1993. Global occurrence of Plasmodium vivaxlike human malaria parasite. J. Infect. Dis. 168:1485-1489.

14. de Arruda M, Souza RC, Veiga ME, Ferreira AF, Zimmerman RH. 1998. Prevalence of Plasmodium vivax variants VK247 and $P$. vivax-like human malaria: a retrospective study in indigenous Indian populations of the Amazon region of Brazil. Trans. R. Soc. Trop. Med. Hyg. 92:628. doi:10 .1016/S0035-9203(98)90788-X.

15. Marrelli MT, Branquinho MS, Hoffmann EH, Taipe-Lagos CB, Natal D, Kloetzel JK. 1998. Correlation between positive serology for Plasmodium vivax-like/Plasmodium simiovale malaria parasites in the human and anopheline populations in the State of Acre, Brazil. Trans. R. Soc. Trop. Med. Hyg. 92:149-151.

16. Bonilla JA, Validum L, Cummings R, Palmer CJ. 2006. Genetic diversity of Plasmodium vivax Pvcsp and Pvmsp1 in Guyana, South America. Am. J. Trop. Med. Hyg. 75:830-835.

17. Gopinath R, Wongsrichanalai C, Cordón-Rosales C, Mirabelli L, Kyle D, Kain KC. 1994. Failure to detect a Plasmodium vivax-like malaria parasite in globally collected blood samples. J. Infect. Dis. 170:1630-1633.

18. Takeuchi O, Hoshino K, Kawai T, Sanjo H, Takada H, Ogawa T, Takeda K, Akira S. 1999. Differential roles of TLR2 and TLR4 in recognition of gram-negative and gram-positive bacterial cell wall components. Immunity 11:443-451.

19. Feuillet V, Medjane S, Mondor I, Demaria O, Pagni PP, Galán JE, Flavell RA, Alexopoulou L. 2006. Involvement of Toll-like receptor 5 in the recognition of flagellated bacteria. Proc. Natl. Acad. Sci. U. S. A. 103: 12487-12492.

20. Kawai T, Adachi O, Ogawa T, Takeda K, Akira S. 1999. Unresponsiveness of MyD88-deficient mice to endotoxin. Immunity 11:115-122.

21. Camacho AG, Teixeira LH, Bargieri DY, Boscardin SB, Soares IS, Nussenzweig RS, Nussenzweig V, Rodrigues MM. 2011. TLR5dependent immunogenicity of a recombinant fusion protein containing an immunodominant epitope of malarial circumsporozoite protein and the FliC flagellin of Salmonella Typhimurium. Mem. Inst. Oswaldo Cruz 106(Suppl 1):167-171. http://dx.doi.org/10.1590/S0074-0276201100090 0021.

22. Gupta RK, Siber GR. 1995. Method for quantitation of IgG subclass antibodies in mouse serum by enzyme-linked immunosorbent assay. J. Immunol. Methods 181:75-81.

23. Nardin EH, Nussenzweig V, Nussenzweig RS, Collins WE, Harinasuta KT, Tapchaisri P, Chomcharn Y. 1982. Circumsporozoite proteins of human malaria parasites Plasmodium falciparum and Plasmodium vivax. J. Exp. Med. 156:20-30.

24. Sanders CJ, Franchi L, Yarovinsky F, Uematsu S, Akira S, Nuñez G, Gewirtz AT. 2009. Induction of adaptive immunity by flagellin does not require robust activation of innate immunity. Eur. J. Immunol. 39:359371 .

25. Vijay-Kumar M, Carvalho FA, Aitken JD, Fifadara NH, Gewirtz AT. 2010. TLR5 or NLRC4 is necessary and sufficient for promotion of humoral immunity by flagellin. Eur. J. Immunol. 40:3528-3534.

26. Mizel SB, Bates JT. 2010. Flagellin as an adjuvant: cellular mechanisms and potential. J. Immunol. 185:5677-5682.

27. Caskey M, Lefebvre F, Filali-Mouhim A, Cameron MJ, Goulet JP, Haddad EK, Breton G, Trumpfheller C, Pollak S, Shimeliovich I, Duque-Alarcon A, Pan L, Nelkenbaum A, Salazar AM, Schlesinger SJ, Steinman RM, Sékaly RP. 2011. Synthetic double-stranded RNA induces innate immune responses similar to a live viral vaccine in humans. J. Exp. Med. 208:2357-2366.

28. Treanor JJ, Taylor DN, Tussey L, Hay C, Nolan C, Fitzgerald T, Liu G, Kavita U, Song L, Dark I, Shaw A. 2010. Safety and immunogenicity of a recombinant hemagglutinin influenza-flagellin fusion vaccine (VAX125) in healthy young adults. Vaccine 28:8268-8274.

29. Taylor DN, Treanor JJ, Sheldon EA, Johnson C, Umlauf S, Song L, Kavita U, Liu G, Tussey L, Ozer K, Hofstaetter T, Shaw A. 2012. Development of VAX128, a recombinant hemagglutinin (HA) influenzaflagellin fusion vaccine with improved safety and immune response. Vaccine 30:5761-5769.

30. Yoshida N, Nussenzweig RS, Potocnjak P, Nussenzweig V, Aikawa M. 1980. Hybridoma produces protective antibodies directed against the sporozoite stage of malaria parasite. Science 207:71-73.

31. Charoenvit Y, Collins WE, Jones TR, Millet P, Yuan L, Campbell GH, 
Beaudoin RL, Broderson JR, Hoffman SL. 1991. Inability of malaria vaccine to induce antibodies to a protective epitope within its sequence. Science 251:668-671.

32. Yadava A, Sattabongkot J, Washington MA, Ware LA, Majam V, Zheng H, Kumar S, Ockenhouse CF. 2007. A novel chimeric Plasmodium vivax circumsporozoite protein induces biologically functional antibodies that recognize both VK210 and VK247 sporozoites. Infect. Immun. 75:11771185.

33. Bell BA, Wood JF, Bansal R, Ragab H, Cargo J, III, Washington MA Wood CL, Ware LA, Ockenhouse CF, Yadava A. 2009. Process development for the production of an E. coli produced clinical grade recombinant malaria vaccine for Plasmodium vivax. Vaccine 27:1448-1453.

34. Lumsden JM, Pichyangkul S, Srichairatanakul U, Yongvanitchit $\mathrm{K}$, Limsalakpetch A, Nurmukhambetova S, Klein J, Bertholet S, Vedvick TS, Reed SG, Sattabongkot J, Bennett JW, Polhemus ME, Ockenhouse CF, Howard RF, Yadava A. 2011. Evaluation of the safety and immunogenicity in rhesus monkeys of a recombinant malaria vaccine for Plasmodium vivax with a synthetic Toll-like receptor 4 agonist formulated in an emulsion. Infect. Immun. 79:3492-3500.

35. Moon JJ, Suh H, Li AV, Ockenhouse CF, Yadava A, Irvine DJ. 2012. Enhancing humoral responses to a malaria antigen with nanoparticle vac- cines that expand Tfh cells and promote germinal center induction. Proc. Natl. Acad. Sci. U. S. A. 109:1080-1085.

36. Lumsden JM, Nurmukhambetova S, Klein JH, Sattabongkot J, Bennett JW, Bertholet S, Fox CB, Reed SG, Ockenhouse CF, Howard RF, Polhemus ME, Yadava A. 2012. Evaluation of immune responses to a Plasmodium vivax CSP-based recombinant protein vaccine candidate in combination with second-generation adjuvants in mice. Vaccine 30: 3311-3319.

37. Yadava A, Nurmukhambetova S, Pichugin AV, Lumsden JM. 2012. Cross-species immunity following immunization with a circumsporozoite protein-based vaccine for malaria. J. Infect. Dis. 205:1456-1463.

38. Corradin G, Céspedes N, Verdini A, Kajava AV, Arévalo-Herrera M, Herrera S. 2012. Malaria vaccine development using synthetic peptides as a technical platform. Adv. Immunol. 114:107-149.

39. Arévalo-Herrera M, Soto L, Perlaza BL, Céspedes N, Vera O, Lenis AM, Bonelo A, Corradin G, Herrera S. 2011. Antibody-mediated and cellular immune responses induced in naive volunteers by vaccination with long synthetic peptides derived from the Plasmodium vivax circumsporozoite protein. Am. J. Trop. Med. Hyg. 84(2 Suppl):35-42. doi:10.4269/ajtmh .2011.09-0507. 


\section{APÊNDICE C}

"Immunogenicity of a prime-boost vaccine containing the circumsporozoite proteins of Plasmodium vivax in rodents" (Teixeira et al., 2013) 


\title{
Immunogenicity of a Prime-Boost Vaccine Containing the Circumsporozoite Proteins of Plasmodium vivax in Rodents
}

\author{
Lais H. Teixeira, ${ }^{a, b}$ Cibele A. Tararam, ${ }^{a, b}$ Marcio O. Lasaro, ${ }^{c *}$ Ariane G. A. Camacho, ${ }^{a, b}$ Jonatan Ersching, ${ }^{a, b}$ Monica T. Leal, ${ }^{a, b}$ \\ Sócrates Herrera, ${ }^{d}$ Oscar Bruna-Romero, ${ }^{\text {e }}$ Irene S. Soares, ${ }^{f}$ Ruth S. Nussenzweig, ${ }^{\text {g }}$ Hildegund C. J. Ertl, ${ }^{\text {c }}$ Victor Nussenzweig, ${ }^{\text {g }}$ \\ Mauricio M. Rodrigues ${ }^{a, b}$ \\ Centro de Terapia Celular e Molecular (CTCMol)a and Departamento de Microbiologia, Imunologia e Parasitologia, ${ }^{b}$ Universidade Federal de São Paulo-Escola Paulista de \\ Medicina, São Paulo, SP, Brazil; The Wistar Institute, Philadelphia, Pennsylvania, USA'; Malaria Vaccine and Drug Development Center, Cali, Colombia ; Departamento de \\ Microbiologia, Imunologia e Parasitologia, Universidade Federal de Santa Catarina, Florianópolis, SC, Brazile; Departamento de Análises Clínicas e Toxicológicas, Faculdade \\ de Ciências Farmacêuticas, Universidade de São Paulo, São Paulo, SP, Brazilf; Michael Heidelberger Division, Department of Pathology, New York University School of \\ Medicine, New York, New York, USA
}

Plasmodium vivax is the most widespread and the second most prevalent malaria-causing species in the world. Current measures used to control the transmission of this disease would benefit from the development of an efficacious vaccine. In the case of the deadly parasite $P$. falciparum, the recombinant RTS,S vaccine containing the circumsporozoite antigen (CSP) consistently protects 30 to $50 \%$ of human volunteers against infection and is undergoing phase III clinical trials in Africa with similar efficacy. These findings encouraged us to develop a $P$. vivax vaccine containing the three circulating allelic forms of $P$. vivax CSP. Toward this goal, we generated three recombinant bacterial proteins representing the CSP alleles, as well as a hybrid polypeptide called PvCSP-All-CSP-epitopes. This hybrid contains the conserved $\mathrm{N}$ and $\mathrm{C}$ termini of $P$. vivax CSP and the three variant repeat domains in tandem. We also generated simian and human recombinant replication-defective adenovirus vectors expressing PvCSP-All-CSP-epitopes. Mice immunized with the mixture of recombinant proteins in a formulation containing the adjuvant poly $(\mathrm{I} \cdot \mathrm{C})$ developed high and long-lasting serum IgG titers comparable to those elicited by proteins emulsified in complete Freund's adjuvant. Antibody titers were similar in mice immunized with homologous (protein-protein) and heterologous (adenovirus-protein) vaccine regimens. The antibodies recognized the three allelic forms of CSP, reacted to the repeated and nonrepeated regions of CSP, and recognized sporozoites expressing the alleles VK210 and VK247. The vaccine formulations described in this work should be useful for the further development of an anti-P. vivax vaccine.

$\mathrm{H}$ uman malaria infection starts when an Anopheles mosquito injects sporozoites of Plasmodium species into the skin of a person. The sporozoites traverse the skin, enter the blood circulation, and infect hepatocytes. While sporozoites are in the skin or migrating to the liver, their infectivity can be abolished by antibodies against the circumsporozoite antigen (CSP). The neutralizing antibodies are predominantly, but not exclusively, directed against the immunodominant B epitopes in the CSP repeat domain (reviewed in reference 1 ).

Multiple trials with experimental animals and more recently with humans provide a solid basis for the use of vaccines against CSP to prevent malaria. Thus far, the only vaccine against the deadly Plasmodium falciparum parasite tested in a phase III clinical trial is RTS,S, a fusion protein between portions of CSP and the hepatitis B surface antigen ( $S$ ) that is administered in a powerful adjuvant system (AS), either an oil-in-water emulsion (AS02) or a liposomal suspension (AS01). These adjuvants contain monophosphoryl lipid A (a detoxified form of lipopolysaccharide [LPS]) and QS21 (purified saponin from Quillaja saponaria). Clinical phase IIa trials with naive, vaccinated volunteers who were challenged with bites from mosquitoes infected with $P$. falciparum reported protective efficacies of 32 to $50 \%$. Protective immunity largely correlated with the serum levels of specific IgG antibodies against the repeats in the CSP antigen and, to a lesser extent, with the frequency of $\mathrm{CD} 4{ }^{+} \mathrm{T}$ cells expressing two or more of the following cytokines: interleukin-2 (IL-2), tumor necrosis factor alpha (TNF- $\alpha$ ), and gamma interferon (IFN- $\gamma$ ) (2).

One of these formulations (RTS,S/AS01E) is currently being tested in a large phase III clinical trial of African children living in areas where malaria is endemic. The results reported from this trial indicate 49.5 or $30.1 \%$ protective efficacy during a 14 -month period postvaccination in 5- to 17 -month-old or 6- to 12 -weekold African children, respectively $(3,4)$. These trials and previous human trials have established that immunodominant CSP is a worthwhile candidate antigen to be included in future vaccine formulations to combat malaria infections, including infections with $P$. vivax.

$P$. vivax is the most widespread malaria-causing species in the world and is the second most prevalent. It is estimated that more than 2.8 billion people are at risk of contracting $P$. vivax infection (5). Nevertheless, only three clinical trials based on subunit $P$. vivax vaccines have been completed (http://www.clinicaltrials .gov/). One complication of $P$. vivax vaccine development is that, in contrast to $P$. falciparum, different allelic forms of $P$. vivax CSP

Received 4 November 2013 Accepted 30 November 2013

Published ahead of print 9 December 2013

Editor: J. H. Adams

Address correspondence to Mauricio M. Rodrigues, mrodrigues@unifesp.br.

* Present address: Marcio O. Lasaro, Biotherapeutics Department, Boehringer Ingelheim Pharmaceutics Inc., Ridgefield, Connecticut, USA.

L.H.T. and C.A.T. contributed equally to this work

Copyright @ 2014, American Society for Microbiology. All Rights Reserved. doi:10.1128/IAl.01410-13 
have been described. The two most common CSP alleles are VK210 and VK247 $(6,7)$. A third allelic form exists at a low frequency $(8-12)$. The main variation among these allelic forms is in the central repeat region of CSP, which is a possible target of neutralizing antibodies.

To generate a vaccine with universal coverage against $P$. vivax malaria strains, we tested a prime-boost regimen using recombinant proteins and adenovirus vectors expressing epitopes from the three CSP alleles as antigens. We used two approaches to generate these vaccines. The first consisted of mixing recombinant proteins expressing the three CSP alleles to generate a vaccine. Additionally, we generated a single recombinant fusion protein called PvCSP-All-CS-epitopes that contains epitopes from the three $P$. vivax CSP alleles. We primed animals with either a simian or a human recombinant replication-defective adenovirus vector expressing PvCSP-All-CS-epitopes in some experiments. In most of the experiments, recombinant antigens were administered in a formulation containing the adjuvant poly $(\mathrm{I} \cdot \mathrm{C})$. We compared the immunogenicities of homologous (protein-protein) and heterologous (adenovirus-protein) immunization regimens. We primarily measured the magnitude and longevity of the serum IgG responses to all of CSP and the CSP domains. In selected experiments, we also evaluated the cell-mediated immune response to CSP.

\section{MATERIALS AND METHODS}

Ethics statement. This study was carried out in strict accordance with the recommendations provided by Guide for the Care and Use of Laboratory Animals of the Brazilian National Council of Animal Experimentation (http://www.cobea.org.br/). The protocol was approved by the Committee on the Ethics of Animal Experiments of the Institutional Animal Care and Use Committee at the Federal University of Sao Paulo (ID number CEP 0307/09). Six- to 8-week-old isogenic female C57BL/6 (H-2 $\left.{ }^{\mathrm{b}}\right)$ mice were maintained under specific-pathogen-free conditions were purchased from the Center for Development of Experimental Models for Medicine and Biology (Federal University of São Paulo, São Paulo, Brazil). tlr4 knockout $\left(t l r 4^{-1-}\right)$ C57BL/6 mice were kindly provided by Shizuo Akira, Osaka University, Osaka, Japan (13). Experiments were approved by the Ethics Committee in Research of the Federal University of São Paulo and São Paulo Hospital (CEP 0307/09).

Generation of recombinant bacterial proteins containing sequences of the CSP antigen of $P$. vivax. For immunization, recombinant bacterial proteins representing the different allelic forms of $P$. vivax CSP were expressed and purified as described below. These recombinant proteins were named $\mathrm{His}_{6}$-PvCSP-VK210, $\mathrm{His}_{6}$-PvCSP-VK247, His ${ }_{6}$-PvCSPVivax-like, and $\mathrm{His}_{6}$-PvCSP-All-CSP-epitopes. The deduced amino acid sequences of the recombinant proteins are depicted in Fig. 1B. Codonoptimized synthetic genes were purchased from GenScript Inc. that contained the sequences of nucleotides PvCSP-vk210, PvCSP-vk247, PvCSPVivax-like, and PvCSP-All-CSP-epitopes. These genes were subcloned into the commercial pET28a expression vector (Novagen), expressed, and purified as follows. Recombinant Escherichia coli BL21(DE3) (Novagen) transformed with each recombinant plasmid was cultivated at $37^{\circ} \mathrm{C}$ in flasks containing Luria broth (LB) and kanamycin $(30 \mu \mathrm{g} / \mathrm{ml})$. Protein expression was induced at an optical density at $600 \mathrm{~nm}\left(\mathrm{OD}_{600}\right)$ of 0.6 with $0.1 \mathrm{mM}$ isopropyl- $\beta$-D-thiogalactopyranoside (Invitrogen) for $4 \mathrm{~h}$. After centrifugation, bacteria were lysed on ice with an ultrasonic processor (Sonics and Materials Inc. Vibra Cell VCX 750) in phosphate buffer ( $\mathrm{pH}$ 8.0 ) with $1.0 \mathrm{mg} / \mathrm{ml}$ lysozyme (Sigma) and $1 \mathrm{mM}$ phenylmethylsulfonyl fluoride (Sigma). The bacterial lysate was centrifuged, and the supernatant was resuspended in $8 \mathrm{M}$ urea (Invitrogen). After being boiled at $100^{\circ} \mathrm{C}$ for $15 \mathrm{~min}$, the proteins were applied to a column with $\mathrm{Ni}^{2+}$ nitrilotriacetic acid-agarose resin (Qiagen). After several washes, bound proteins were eluted with $0.5 \mathrm{M}$ imidazole (Sigma). The eluted protein was dialyzed against $20 \mathrm{mM}$ Tris- $\mathrm{HCl}(\mathrm{pH} 8.0)$, and the recombinant proteins were purified by ion-exchange chromatography with a Resource Q column (GE Healthcare) coupled to a fast protein liquid chromatography system (GE Healthcare). Fractions containing the recombinant proteins with a high degree of purity were pooled and incubated with polymyxin B-agarose (Sigma) overnight. Unbound material was extensively dialyzed against phosphate-buffered saline (PBS; pH 7.2). Protein concentration was determined with the Bradford assay and by SDS-PAGE analyses. LPS determination was done with the E-TOXATE kit (Sigma). Tests were performed with different dilutions of each sample, and the results demonstrated that the LPS contamination varied between 300 and 3,000 endotoxin $\mathrm{U} / \mathrm{mg}$ of purified protein.

In addition, for epitope mapping, we used $\mathrm{His}_{6}$-FliC, $\mathrm{His}_{6}$-FliCPvCSP-VK210, His $_{6}$-FliC-PvCSP-VK247, and His $_{6}$-FliC-PvCSP-Vivaxlike. These proteins were generated as described in detail in reference 14. Finally, a recombinant protein devoid of the repeat regions expressing the $\mathrm{N}$ - and C-terminal regions of CSP was generated and named $\mathrm{His}_{6}$-PvCSPNo-repeats. These recombinant proteins were expressed and purified as described previously (15).

Generation of recombinant replication-defective adenovirus vectors expressing sequences encoding the CSP antigens of $P$. vivax. Recombinant replication-defective human adenovirus serotype 5 (AdHu5) and chimpanzee adenovirus serotype 68 (AdC68) vectors were generated, purified, quality controlled, and titrated as previously described (16), with the sequence ad-PvCSP. For the deduced amino acid sequence of the CS antigen, see Fig. 6B.

Immunization regimens. Mice were given three immunizations 3 weeks apart subcutaneously (s.c.) in the two hind footpads with a final volume of $50 \mu \mathrm{l}$ for each footpad (first dose) and a final volume of $100 \mu \mathrm{l}$ at the base of the tail (second and third doses). For each dose, the indicated amount of protein was used. Complete Freund's adjuvant (CFA) and incomplete Freund's adjuvant (IFA) (Sigma) were emulsified with the protein antigens $(1: 1, \mathrm{vol} / \mathrm{vol})$ prior to injection. For the CFA-IFA immunization regimens, CFA was used for the first dose and IFA was used for subsequent doses. As additional adjuvants, $50 \mu \mathrm{g}$ of high-molecularweight poly (I.C) (InvivoGen) or Hiltonol (PolyICL, Oncovir Inc., kindly provided by A. M. Salazar) was mixed with the protein antigens in a final volume of $100 \mu \mathrm{l}$.

Recombinant adenovirus vectors were injected intramuscularly (i.m.) into the tibialis anterioris with a final volume of $50 \mu \mathrm{l}$ for each leg.

Peptide synthesis. Synthetic peptides were purchased from GenScript (Piscataway, NJ). Peptide purity was higher than 90\%. Peptide identities were confirmed by a Q-TOF Micro equipped with an electrospray ionization source (Micromass UK Ltd., Manchester, United Kingdom).

Immunological assays. Serum IgG anti- $P$. vivax CSP antibodies were detected by enzyme-linked immunosorbent assay (ELISA) as previously described $(14,15)$. The recombinant proteins (100 to $200 \mathrm{ng} /$ well) were used as the solid-phase bound antigen. A peroxidase-conjugated goat anti-mouse IgG (Sigma) was applied at a final dilution of 1:1,000, while the sera from mice were tested at serial dilutions starting with 1:200. Specific antibody titers were determined as the highest dilution yielding an $\mathrm{OD}_{492}$ higher than 0.1. In parallel, we performed a standard curve of purified mouse IgG (Sigma) by using the anti-Fab (Sigma) capture antibody according to the protocol suggested in reference 17.

Detection of IgG subclass responses was performed as described above, except that the secondary antibody was specific for mouse IgG1, IgG2b, and IgG2c (Southern Technologies). The results are presented as means \pm standard deviations (SD).

Monoclonal antibodies (MAbs) against $P$. vivax CS proteins representing the allelic forms VK210 (2F2) and VK247 (2E10.E9; Alan Cochrane, unpublished results) were generated after immunization with radiation-attenuated sporozoites (18). The hybridomas used were obtained from the Malaria Research and Reference Reagent Resource Center (MR4). Polyclonal antibodies against the P. vivax-like epitopes were ob- 


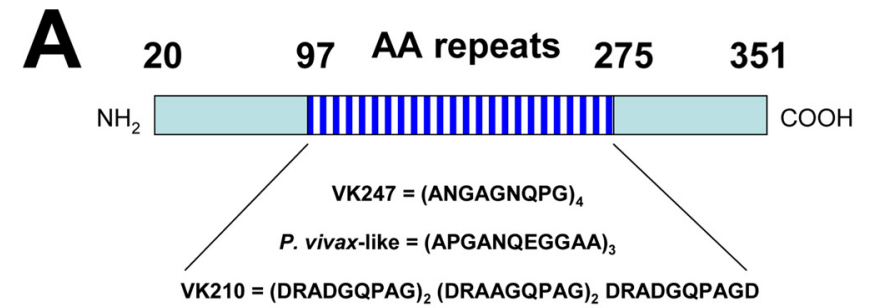

C

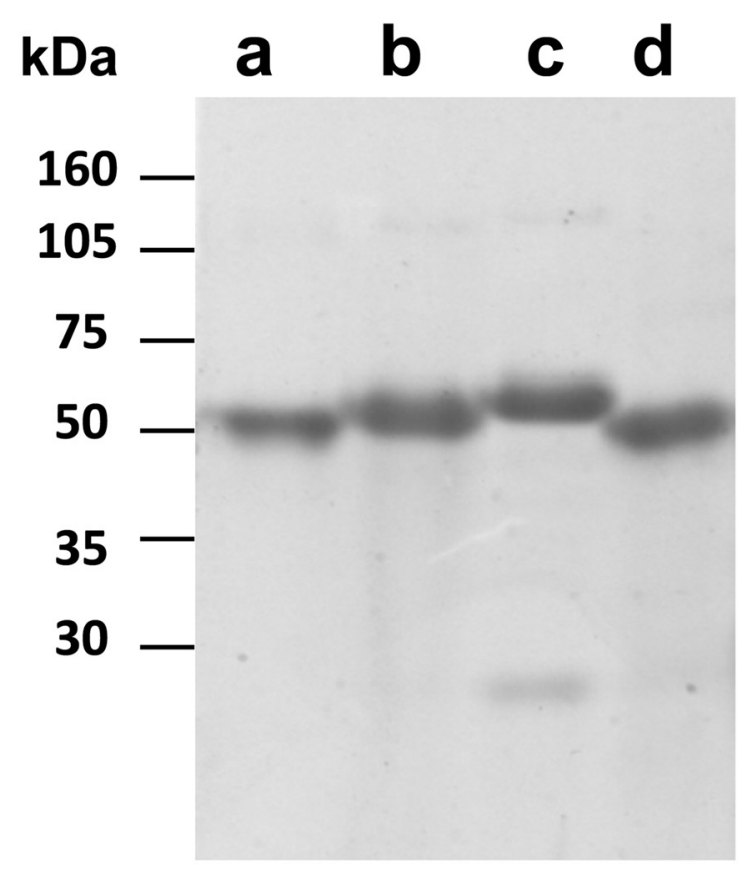

\section{$\mathrm{His}_{6}-\mathrm{PvCSP}-\mathrm{VK210}$}

\begin{tabular}{|c|c|c|c|c|c|}
\hline 10 & 20 & 30 & 40 & 50 & 60 \\
\hline SSHHHHH $\bar{H}$ & SSGLVPRGSH & 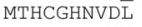 & SKAINLNGVN & FNNVDASSL $\bar{G}$ & AAHVGQSASR \\
\hline 70 & 80 & 90 & 100 & 110 & 120 \\
\hline RGLGENPDD & EEGDAKKKK KD & GKKAEPKNP $\bar{R}$ & ENKLKQPGDR & ADGQPAGDR $\bar{A}$ & DGQPAGDRAD \\
\hline 13 & & & 160 & 170 & \\
\hline QPAGDRADG & QPAGDRAAG $\bar{Q}$ & PAGDRADGQ $\overline{\mathrm{P}}$ & AGDRADGQP $\bar{A}$ & GDRADGQPAG & DRADGQPAGD \\
\hline & & 210 & 220 & $23 \underline{0}$ & \\
\hline AAGQPAGD & AAGQPAGDR & GQPAGDRA $\bar{A}$ & GQPAGDRADG & 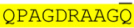 & PAGDRADGQ \\
\hline $25 \underline{0}$ & $26 \underline{0}$ & $27 \underline{0}$ & 280 & 290 & 30 \\
\hline GDRAAGQP $\bar{A}$ & GDRAAGQPAG & AAGQAAG $\bar{D}$ & 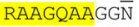 & AGGQGQNNE $\bar{G}$ & ANAPNEKSVK \\
\hline 310 & 325 & 330 & 340 & 350 & \\
\hline
\end{tabular}

His $_{6}$-PvCSP-VK247

\begin{tabular}{|c|c|c|c|c|c|}
\hline $1 \underline{0}$ & $2 \underline{0}$ & $3 \underline{0}$ & 40 & $5 \underline{0}$ & $6 \underline{0}$ \\
\hline GSSHHHHH & SSGLVPRGS $\bar{H}$ & MTHCGHNVD $\bar{I}$ & SKAINLNGVN & FNNVDASSLG & AAHVGQSASR \\
\hline $7 \underline{0}$ & $8 \underline{0}$ & 90 & 100 & 110 & \\
\hline RGLGENPDD & EEGDAKKKK $\bar{D}$ & GKKAEPKNP $\bar{R}$ & ENKLKQPGA $\bar{N}$ & GAGNQPGANG & AGN \\
\hline 130 & 140 & 150 & 160 & 170 & 180 \\
\hline SNQPGANGAG & NQPGANGAGN & QPGANGAGNQ & PGANGAGNQP & GANGAGNQPG & ANGAGNQPGA \\
\hline 190 & 200 & 210 & 220 & 230 & 240 \\
\hline NGAGNQPGAN & GAGNQPGANG & AGNQPGANGA & GNQPGANGĀ & NQPGANGAGN & QPGANGAGNQ \\
\hline 250 & 260 & 270 & $28 \underline{0}$ & $29 \underline{0}$ & $30 \underline{0}$ \\
\hline GANGAGNQP & GANGAGNQPG & ANGAGNQPGA & NGAGNQPGGN & AGGQGQNNEG & ANAPNEKSVK \\
\hline $31 \underline{0}$ & $32 \underline{0}$ & $33 \underline{0}$ & $34 \underline{0}$ & $35 \underline{0}$ & \\
\hline & ${ }^{\prime T} \bar{T}$ & & & & \\
\hline
\end{tabular}

His $_{6}$-PvCSP-Vivax-like

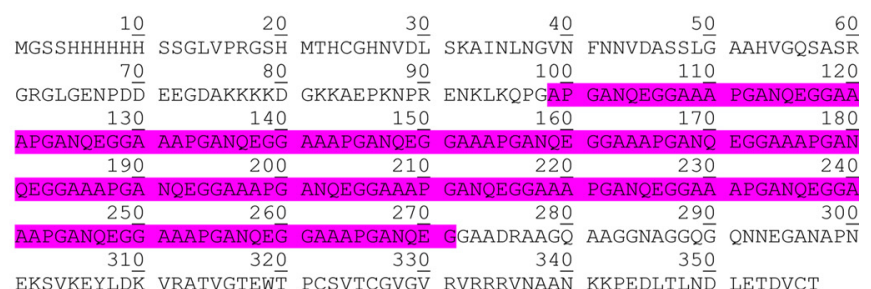

His $_{6}$-PvCSP-All CS epitopes

\begin{tabular}{|c|c|c|c|c|c|}
\hline $1 \underline{0}$ & $2 \underline{0}$ & $3 \underline{0}$ & $4 \underline{0}$ & $5 \underline{0}$ & $6 \underline{0}$ \\
\hline GSSHHHHH & SSGLVPRGSH & 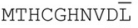 & SKAINLNGVN̄ & FNNVDASSL $\bar{G}$ & AAHVGQSASR \\
\hline $7 \underline{0}$ & 80 & 90 & 100 & 110 & $12 \underline{0}$ \\
\hline GRGLGENPDD & EEGDAKKKKD & GKKAEPKNPR & ENKLKQPGPG & DRADGQPAGD & RADGQPAGDR \\
\hline 130 & 140 & 150 & 160 & 170 & 180 \\
\hline AAGQPAGDRA $\bar{A}$ & AGQPAGDRA $\bar{D}$ & GQPAGDRADG & QPAGDRADAP & & \\
\hline 190 & 200 & 210 & 220 & 230 & 240 \\
\hline 10 & JQF & 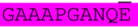 & SANQ & ANGA & GNQPGANGAG \\
\hline 250 & 260 & 270 & $28 \underline{0}$ & $29 \underline{0}$ & $30 \underline{0}$ \\
\hline 2PGANGAGN & QPGANGAGNQ & PGANGAGNQP & GDRAAGQAA $\overline{\bar{G}}$ & GNAGGQGQNN & 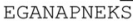 \\
\hline & 320 & 330 & $34 \underline{0}$ & $35 \underline{0}$ & \\
\hline
\end{tabular}

FIG 1 Production and purification of $P$. vivax CSP recombinant proteins. (A) Schematic representation of the P. vivax CSP antigen and the sequences of the repeat regions present in each allelic form (PvCSP-VK210, PvCSP-VK247, or PvCSP-Vivax-like). (B) The predicted amino acid sequence of each recombinant protein. (C) Recombinant proteins were purified by affinity purification followed by anion-exchange chromatography and separated by SDS-PAGE under

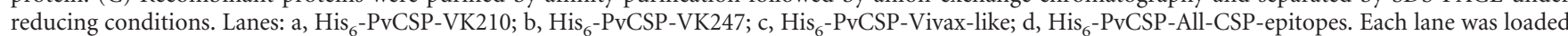
with $1 \mu \mathrm{g}$ of protein.

tained from C57BL/6 mice immunized with the $\mathrm{His}_{6}$-FliC-PvCSP-Vivaxlike antigen as described previously (14). MAbs to the His tag were purchased from GE Healthcare Systems.

Cell-mediated immunity assays. Splenocytes collected from immunized C57BL/6 mice were used for enzyme-linked immunospot (ELISPOT) assays to measure the secretion of IFN- $\gamma$ and for in vivo cytotoxicity assays. These assays were performed as in our previous studies $(19,20)$.

For assays of the expression of the intracellular cytokines (ICs) IFN- $\gamma$ and TNF- $\alpha$, splenocytes collected from C57BL/6 mice were treated with ACK buffer $\left(\mathrm{NH}_{4} \mathrm{Cl}, 0.15 \mathrm{M}\right.$; $\mathrm{KHCO}_{3}, 10 \mathrm{mM}$; Na $\mathrm{N}_{2}$-EDTA, $0.1 \mathrm{mM} ; \mathrm{pH}$ 7.4) to lyse the erythrocytes. ICs were evaluated after in vitro culture of splenocytes in the presence or absence of the indicated antigenic stimulus.
Cells were washed in cell culture medium consisting of RPMI 1640 medium, $\mathrm{pH}$ 7.4, supplemented with $10 \mathrm{mM}$ HEPES, $0.2 \%$ sodium bicarbonate, $59 \mathrm{mg} /$ liter of penicillin, $133 \mathrm{mg} /$ liter of streptomycin, and $10 \%$ HyClone fetal bovine serum (HyClone, Logan, UT). The viability of the cells was evaluated with $0.2 \%$ trypan blue. The cell concentration was adjusted to $5 \times 10^{6} / \mathrm{ml}$ of cell culture medium containing anti-CD28 (2 $\mu \mathrm{g} / \mathrm{ml})$, brefeldin A $(10 \mu \mathrm{g} / \mathrm{ml})$, and monensin $(5 \mu \mathrm{g} / \mathrm{ml}$; BD Pharmingen). To half of the cultures, a final concentration of $10 \mu \mathrm{g} / \mathrm{ml}$ of the indicated peptides or recombinant proteins or $2 \mu \mathrm{g} / \mathrm{ml}$ of concanavalin A (ConA; Sigma) was added. The cells were cultivated in V-bottom 96-well plates (Corning) in a final volume of $200 \mu \mathrm{l}$ in duplicate at $37^{\circ} \mathrm{C}$ in a humid environment containing $5 \% \mathrm{CO}_{2}$. After a 12-h incubation, cells were stained for surface markers with peridinin chlorophyll protein- 
Cy5.5-labeled anti-CD4 (clone RM4-5) or PECy7-labeled CD8 (clone 536.7) on ice for $20 \mathrm{~min}$. To detect IFN- $\gamma$ and TNF- $\alpha$ by intracellular staining, cells were then washed twice in buffer containing PBS, $0.5 \%$ bovine serum albumin (BSA), and 2 mM EDTA, fixed in 4\% PBS-paraformaldehyde solution for $10 \mathrm{~min}$, and permeabilized for $15 \mathrm{~min}$ in a solution of PBS, $0.1 \%$ BSA, and $0.1 \%$ saponin. After being washed twice, cells were stained for intracellular markers with fluorescein isothiocyanate (FITC)labeled anti-IL-2 antibody (JES6-5H4), allophycocyanin-labeled antiIFN- $\gamma$ antibody (clone XMG1.2), and phycoerythrin -labeled anti-TNF- $\alpha$ antibody (clone MP6-XT22) for 20 min on ice. Finally, cells were washed twice and fixed in 1\% PBS-paraformaldehyde. At least 300,000 cells were acquired on a BD FacsCanto flow cytometer and then analyzed with FlowJo (Tree Star, Ashland, OR).

$P$. vivax slide preparation and indirect immunofluorescence assay (IIA). Sera from animals immunized simultaneously with the three recombinant proteins (a mixture of the $\mathrm{His}_{6}$-PvCSP-VK210, $\mathrm{His}_{6}$-PvCSP-

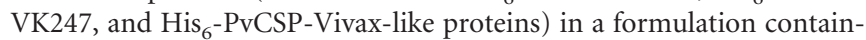
ing the adjuvant poly $(\mathrm{I} \cdot \mathrm{C})$ or from mice that received a heterologous prime-boost vaccination regimen (adenovirus-protein mixture) were selected for the immunofluorescence assay. $P$. vivax sporozoites expressing PvCSP VK210 or VK247 were obtained as previously described $(21,22)$. Slides containing sporozoites fixed in air were blocked with PBS-3\% BSA for $30 \mathrm{~min}$ at room temperature. Slides were incubated in a humid chamber for $1 \mathrm{~h}$ at room temperature with $1 \mu \mathrm{g} / \mathrm{ml}$ of the MAb 2F2 (antiPvCSP-VK210 MAb) as a positive control or with sera from mice were immunized with adjuvant only diluted 1:1,000 as a negative control. Additionally, we used sera from immunized animals that had been diluted $1: 100,1: 1,000,1: 10,000$, and 1:100,000. After immersion in PBS to wash the slides, the slides were incubated for $1 \mathrm{~h}$ at room temperature with PBS-3\% BSA containing FITC-conjugated goat antibody reactive against murine IgG (Kirkegaard \& Perry Laboratories, Inc.) at a concentration of $0.02 \mathrm{mg} / \mathrm{ml}$. The slides were washed in PBS containing $50 \mathrm{mM}$ glycine, slightly dried, and mounted with buffered glycerol. We analyzed the slides under an optical microscope with fluorescence at a magnification of $\times 100$.

Statistical analyses. One-way analysis of variance (ANOVA) and Tukey's honestly significant difference (HSD) test were used to compare the differences between the serum IgG titers of the different groups.

Nucleotide sequence accession numbers. Sequences for PvCSPvk210, PvCSP-vk247, PvCSP-Vivax-like, PvCSP-All-CSP-epitopes, and ad-PvCSP were deposited into GenBank under accession numbers KF971719 to KF971723, respectively.

\section{RESULTS}

Production and purification of $P$. vivax CSP recombinant proteins and recognition by MAbs. Figure $1 \mathrm{~A}$ shows a schematic representation of the $P$. vivax CSP antigen and the sequences of the repeated regions present in the allelic forms of CSP (VK210, VK247, and $P$. vivax-like). Codon-optimized genes were synthesized that contained the same coding regions for the $\mathrm{N}$ and $\mathrm{C}$ termini. The central domain encoded the different allelic forms of the $P$. vivax CSP protein. These genes were expressed as recombinant fusion proteins representing each individual allelic form of the $P$. vivax CSP antigen linked to a hexahistidine $\left(\mathrm{His}_{6}\right)$ tag. These antigens were named $\mathrm{His}_{6}$-PvCSP-VK210, His $_{6}$-PvCSP-VK247, and $\mathrm{His}_{6}$-PvCSP-Vivax-like. The predicted amino acid sequence of each recombinant fusion protein is shown in Fig. 1B. In addition, a fourth synthetic gene was constructed encoding the three distinct allelic forms expressed as a single fusion polypeptide called $\mathrm{His}_{6}$-PvCSP-All-CSP-epitopes (Fig. 1B).

Recombinant proteins were purified as described in Materials and Methods and separated by SDS-PAGE under reducing conditions. Although the predicted molecular masses of the recombinant proteins were $35,207.42,33,633.48,33,878.94$, and $34,346.40$
$\mathrm{Da}$, the apparent molecular masses determined by SDS-PAGE varied from approximately 50,000 to $55,000 \mathrm{Da}$ (Fig. 1C).

To determine whether the polypeptides retained the epitopes recognized by specific MAbs generated against radiation-attenuated $P$. vivax sporozoites, we performed an ELISA with each of the four recombinant proteins bound to the plates. As depicted in Fig. $2 \mathrm{~A}$, all four recombinant proteins were recognized well by a MAb against the His tag. The MAb against allelic variant VK210 (2F2) recognized recombinant proteins $\mathrm{His}_{6}{ }_{-} \mathrm{PvCSP}-\mathrm{VK} 210$ and $\mathrm{His}_{6}{ }^{-}$ PvCSP-All-CSP-epitopes equally well. This MAb extensively cross-reacted with the recombinant protein $\mathrm{His}_{6}$-PvCSP-Vivaxlike and reacted to a minor extent with $\mathrm{His}_{6}$-PvCSP-VK247 (Fig. 2B).

The MAb against the VK247 allele (2E10.E9) reacted with the recombinant proteins $\mathrm{His}_{6}$-PvCSP-VK247 and $\mathrm{His}_{6}$-PvCSP-AllCSP-epitopes equally well. No cross-reactivity with the recombinant protein $\mathrm{His}_{6}$-PvCSP-VK210 or $\mathrm{His}_{6}$-PvCSP-Vivax-like was detected (Fig. 2C). Finally, polyclonal antibodies to the P. vivaxlike repeat region reacted equally well with the recombinant proteins $\mathrm{His}_{6}$-PvCSP-Vivax-like and $\mathrm{His}_{6}$-PvCSP-All-CS-epitopes. No cross-reactivity was detected with the recombinant protein $\mathrm{His}_{6}$-PvCSP-VK210 or $\mathrm{His}_{6}$-PvCSP-VK247 (Fig. 2D). On the basis of these results, we concluded that the repeat epitopes present in the different allelic variants of $P$. vivax were preserved in the bacterial recombinant proteins. Most relevant, the recombinant $\mathrm{His}_{6}$-PvCSP-All-CSP-epitopes were equally recognized by all three different MAbs and polyclonal sera used, indicating the presence of the three distinct epitopes in this fusion polypeptide.

Induction of specific antibody responses in mice immunized with recombinant $P$. vivax CSP antigens. The serum IgG responses to $P$. vivax CSP antigens were determined in C57BL/6 mice immunized s.c. with purified proteins in the presence of the adjuvant $\operatorname{poly}(\mathrm{I} \cdot \mathrm{C})$ or emulsified in complete/incomplete Freund's adjuvant (CFA-IFA). Mice were immunized with three doses 21 days apart, and the antibody titers were analyzed according to the timeline described in Fig. 3A. Twelve mouse groups were immunized with (i) poly (I.C), (ii) poly (I.C) plus $\mathrm{His}_{6}$-PvCSP-VK210 $(10 \mu \mathrm{g} /$ dose/mouse), (iii) poly(I.C) plus $\mathrm{His}_{6}$-PvCSP-VK247 (10 $\mu \mathrm{g} /$ dose/ mouse), (iv) poly(I.C) plus $\mathrm{His}_{6}$-PvCSP-Vivax-like $(10 \mu \mathrm{g} /$ dose/ mouse), (v) poly(I.C) plus a protein mixture (His ${ }_{6}$-PvCSP-VK210, His $_{6}$-PvCSP-VK247, and $\mathrm{His}_{6}$-PvCSP-Vivax-like, $30 \mu \mathrm{g} / \mathrm{dose} /$ mouse), (vi) poly(I·C) plus $\mathrm{His}_{6}$-PvCSP-All-CSP-epitopes $(30 \mu \mathrm{g} /$ dose/mouse), (vii) CFA-IFA, (viii) CFA-IFA plus $\mathrm{His}_{6}$-PvCSP-VK210 (10 $\mu \mathrm{g} /$ dose/mouse), (ix) CFA-IFA plus $\mathrm{His}_{6}$-PvCSP-VK247 $(10 \mu \mathrm{g} /$ dose/mouse), (x) CFA-IFA plus His ${ }_{6}$-PvCSP-Vivax-like $(10 \mu \mathrm{g} /$ dose/mouse), (xi) CFA-IFA plus a protein mixture (His ${ }_{6}$-PvCSPVK210, His $_{6}$-PvCSP-VK247, and $\mathrm{His}_{6}$-PvCSP-Vivax-like, $30 \mu \mathrm{g} /$ dose/mouse), and (xii) CFA-IFA plus $\mathrm{His}_{6}$-PvCSP-All-CSPepitopes (30 $\mu \mathrm{g} /$ dose/mouse).

At the indicated days, the titer of antibody to each individual allelic form of $P$. vivax CSP was determined by ELISA. In all of the groups of mice immunized with a formulation containing recombinant CSP antigen and adjuvant, the antibody titers were above $10^{5}$ after the second dose. According to our standard curve of mouse IgG, this antibody titer represents approximately $50 \mu \mathrm{g} / \mathrm{ml}$ of specific IgG. After the third dose, in some cases, we observed an enhancement of these titers to $\geq 10^{6}$. High antibody titers lasted for a period of 183 days after the first immunization. At that time, titers were still in the range of $10^{5}$ to $10^{6}$.

By comparing the antibody titers of groups of mice immunized 

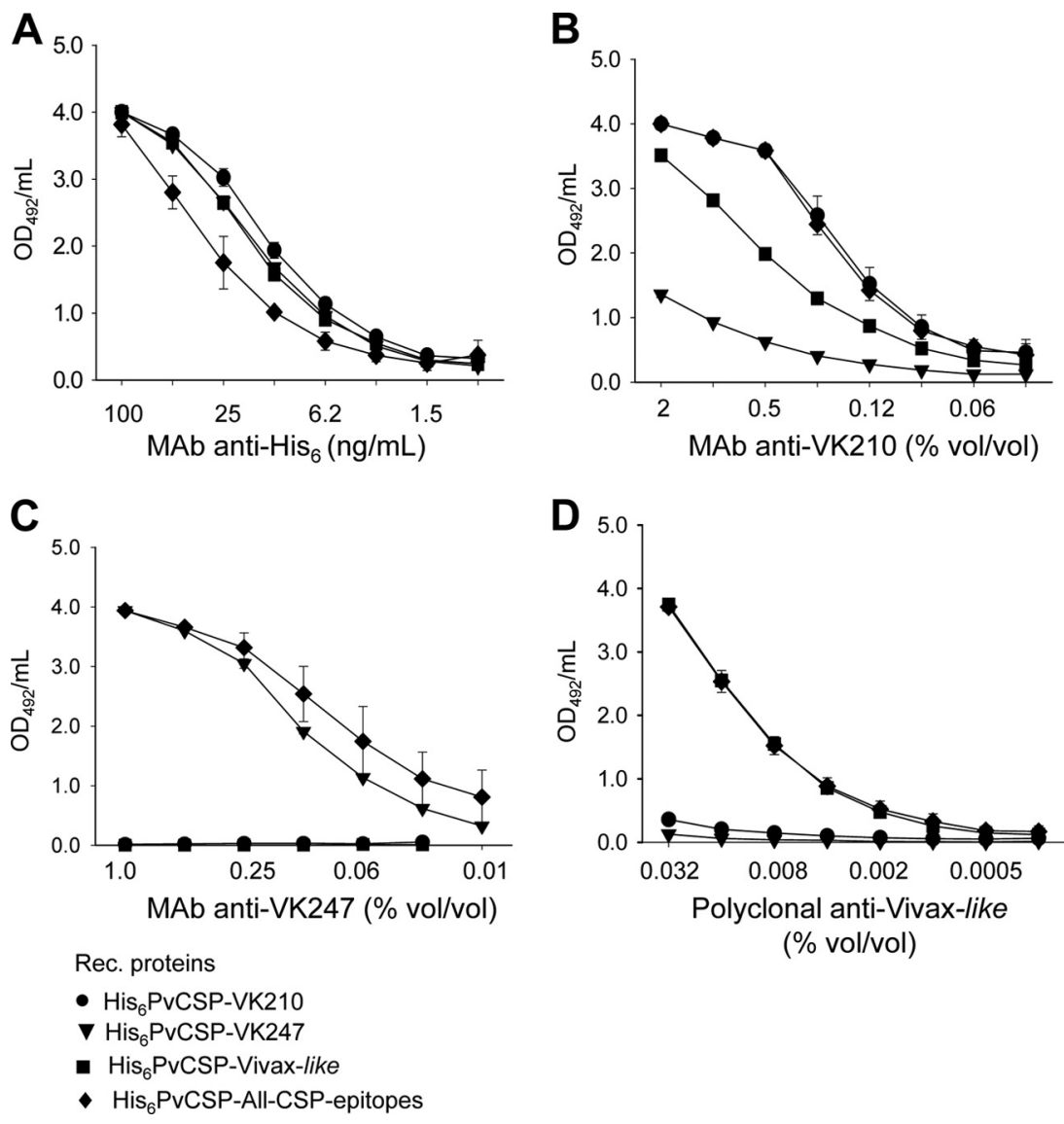

(\% vol/vol)

FIG 2 Antibody recognition of P. vivax CSP recombinant proteins. ELISAs were performed with each of the four PvCSP recombinant (Rec.) proteins bound to the plates to determine whether the polypeptides retained the epitopes recognized by specific MAbs generated against radiation-attenuated $P$. vivax sporozoites. (A) MAb against the His tag. (B) MAb 2F2 specific to the allelic form PvCSP-VK210. (C) MAb 2E10.E9 specific to the allelic form PvCSP-VK247. (D) Polyclonal antibodies to the PvCSP-Vivax-like repeat region.

with the recombinant antigens in the presence of the adjuvant poly (I.C) (Fig. 3B to D), we found that immunization with the protein mixture generated higher antibody titers than immunization with each individual protein or with the protein $\mathrm{His}_{6}-\mathrm{PvCSP}-$ All-CSP-epitopes ( $P<0.01$ in all cases for the period of 183 days). In contrast, all groups of mice immunized with the recombinant CSP antigens emulsified in CFA-IFA produced similar antibody titers (Fig. 3E to G; no statistically significant difference in all cases for the period of 183 days).

We then compared groups of mice injected with the protein mixture or $\mathrm{His}_{6}$-PvCSP-All-CSP-epitopes in formulations containing the adjuvants poly(I.C) or CFA-IFA. We found that immunization with the protein mixture generated similar antibody titers when emulsified in CFA-IFA or mixed with the adjuvant poly (I.C) (no statistically significant difference). In contrast, mice immunized with $\mathrm{His}_{6}$-PvCSP-All-CSP-epitopes emulsified in CFA-IFA displayed significantly higher antibody titers than animals injected with the antigen in the presence of poly $(\mathrm{I} \cdot \mathrm{C})$. These experiments allowed us to conclude that immunization with the protein mixture was superior to immunization with $\mathrm{His}_{6}-\mathrm{PvCSP}-$ All-CSP-epitopes when poly $(\mathrm{I} \cdot \mathrm{C})$ was used as the adjuvant. Additionally, we concluded that when using the protein mixture in the presence of poly $(\mathrm{I} \cdot \mathrm{C})$, the antibody titers could be as high and long lasting as the titers generated by this same protein mixture emulsified in CFA-IFA.
Although the anti-PvCSP-specific IgG antibody titers after immunization with the protein mixture in formulations containing CFA-IFA or poly(I.C) were equally high, these immune responses differed significantly in terms of the subclasses of IgG that were elicited. Responses generated in the presence of CFA-IFA resulted in predominately IgG1 rather than IgG2c (ratio of 19.1), while responses generated in the presence of poly $(\mathrm{I} \cdot \mathrm{C})$ resulted in an IgG1-to-IgG2c subclass ratio of 0.95 .

To compare the potency of poly(I-C) with the commercially available Hiltonol [poly(ICLC)] that is being used in human trials (23), we performed side-by-side comparison experiments by immunizing mice with (i) poly(I-C), (ii) poly (I.C) plus a protein mixture $\left(\mathrm{His}_{6}-\mathrm{PvCSP}-\mathrm{VK} 210\right.$, $\mathrm{His}_{6}-\mathrm{PvCSP}-\mathrm{VK} 247$, and $\mathrm{His}_{6}{ }^{-}$ PvCSP-Vivax-like, $30 \mu \mathrm{g} /$ dose/mouse), or (iii) Hiltonol plus the same protein mixture. We observed that the antibody titers of mice immunized with the protein mixture in the presence of either adjuvant elicited similarly high antibody titers that lasted until at least day 160 (no statistically significant difference; data not shown).

We then determined whether lower doses of the recombinant protein mixture could be as effective in eliciting high and sustained antibody immune responses. For this purpose, mice were immunized side by side with 10 or $1 \mu \mathrm{g}$ of each of the three recombinant proteins in the presence of the adjuvant poly $(\mathrm{I} \cdot \mathrm{C})$. Mice immunized with 30 or $3 \mu \mathrm{g}$ of the total protein mixture 

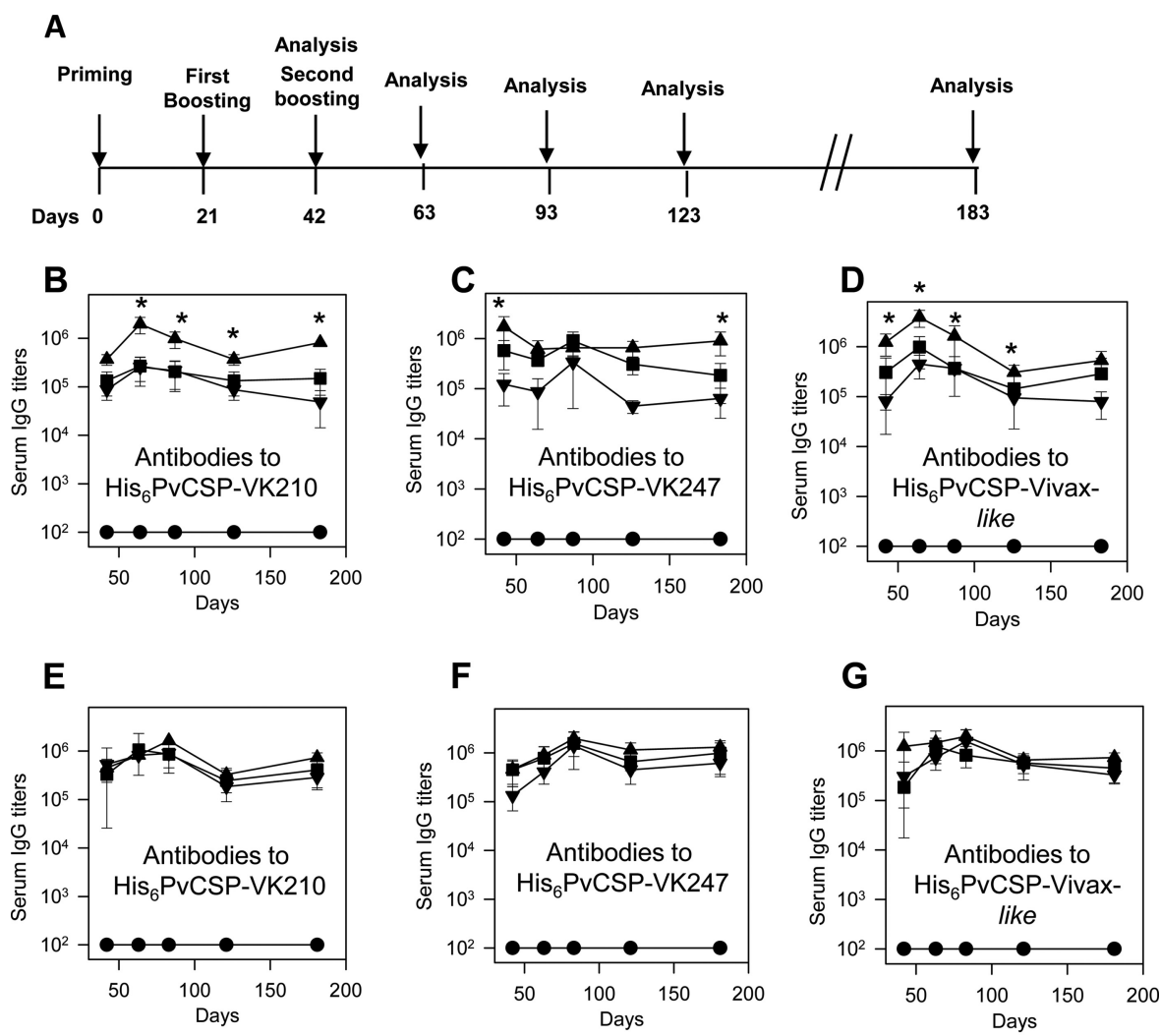

Antigens used for immunizations
- Adjuvant only
Single Protein
A Protein Mix
$\nabla \mathrm{His}_{6} \mathrm{PvCSP}_{\mathrm{C}} \mathrm{All} \mathrm{CS}$ epitopes

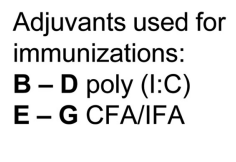

FIG 3 Induction of specific antibody responses in mice immunized with recombinant $P$. vivax CSP antigens. (A) Mice were immunized with three doses 21 days apart, and the antibody titers were analyzed according to the timeline shown. The serum IgG responses to $P$. vivax CS antigens were determined in C57BL/6 mice immunized s.c. with the purified proteins in a formulation containing the adjuvant poly $(\mathrm{I} \cdot \mathrm{C})(\mathrm{B}$ to $\mathrm{D})$ or emulsified in $\mathrm{CFA}$ or IFA (E to G). Mice were immunized

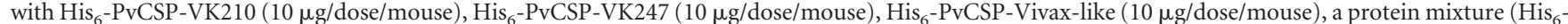
PvCSP-VK210, His $_{6}$-PvCSP-VK247, and $\mathrm{His}_{6}$-PvCSP-Vivax-like, $30 \mu \mathrm{g} / \mathrm{dose} / \mathrm{mouse}$ ), or His ${ }_{6}$-PvCSP-All-CS-epitopes (30 $\mu$ g/dose/mouse). Serum IgG titers of antibodies against recombinant proteins representing each allelic form of PvCSP were measured as indicated. The results are expressed as means \pm SD $(n=6)$ Statistical comparisons by one-way ANOVA of the antibody titers from mice immunized with formulations containing the adjuvant poly(I.C) (B to D) show significantly higher antibody levels in animals immunized with the protein mixture $(P<0.01$, asterisks $)$. Comparisons of the antibody titers of mice immunized with formulations containing the adjuvant CFA-IFA and recombinant proteins did not show statistically significant differences.

responded equally well. Antibody titers above $10^{5}$ lasted for more than 200 days (Fig. 4A to C; no statistically significant difference).

Purified bacterial recombinant proteins often contain traces of contaminating LPS that can interfere with immunogenicity. To show that contaminating LPS was not influencing the immunogenicity results, we performed a side-by-side comparison of the antibody immune responses to the protein mixture when administered to $t l r 4^{+/+}$or $t l r 4^{-1-}$ mice in the presence of poly $(\mathrm{I} \cdot \mathrm{C})$. After immunization, both mouse strains responded equally well for the entire 177-day observation period (Fig. 5A to $\mathrm{C}$; no statistically significant difference). These observations ruled out any possible interference from LPS contamination in our samples.

Induction of specific antibody responses in mice immunized with recombinant adenovirus vectors expressing $P$. vivax CSP as part of a heterologous prime-boost regimen for vaccination. In addition to the recombinant proteins, we generated two recombinant replication-defective adenovirus vectors expressing the gene encoding the PvCSP-All-CSP-epitopes antigen. Schematic representations of the deduced amino acid sequences of the proteins expressed by these recombinant adenovirus vectors are depicted in Fig. 6A and B. Antigen expression was confirmed by infection of HEK-293 cells and immunofluorescence analyses (data not shown). The recombinant adenoviruses were designated AdC68-PvCSP and AdHu5-PvCSP. Immunization of C57BL/6 mice with $2 \times 10^{7} \mathrm{PFU}$ of either of these recombinant adenovirus vectors elicited specific IgG antibodies against each individual allelic form of PvCSP. This dose was determined experimentally as the minimum dose to elicit antibody titers higher than $10^{3}$. After 21 days, titers of antibodies to all three different alleles of recombinant PvCSP were in the range of $10^{4}$. No statistically significant difference was observed in the serum IgG titers between the groups of mice vaccinated with AdC68-PvCSP or AdHu5-PvCSP (Fig. 6C). As expected, control mice injected with the same dose of AdHu $5 \beta$-gal did not generate any $P$. vivax-specific antibodies. However, at a later time point, the antibody titers of mice immu- 

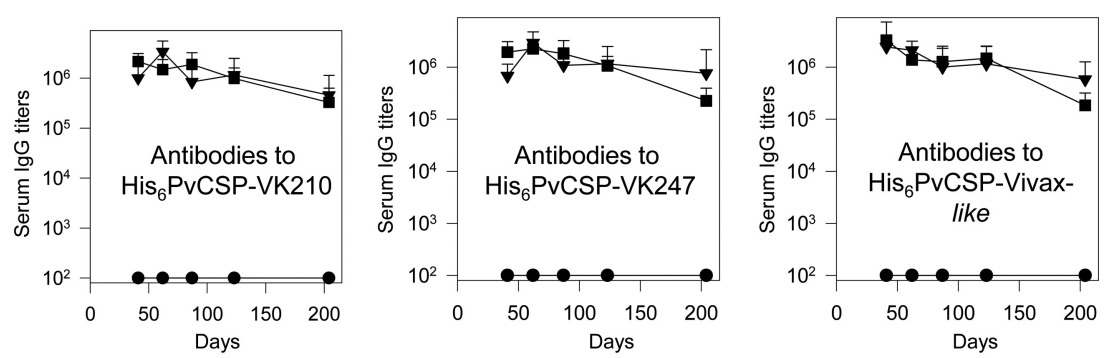

- Adjuvant

$\nabla$ Adjuvant + PvCSP Protein Mix (30 $\mu \mathrm{g} /$ mouse/dose)

- Adjuvant + PvCSP Protein Mix (3 $\mu \mathrm{g} /$ mouse/dose)

FIG 4 Induction of specific antibody responses in mice immunized with recombinant $P$. vivax CSP antigens. C57BL/6 mice were immunized at 30 or 3 $\mu \mathrm{g} /$ dose/mouse with a formulation containing a protein mixture ( $\mathrm{His}_{6}-\mathrm{PvCSP}-\mathrm{VK} 210$, $\mathrm{His}_{6}$-PvCSP-VK247, and His ${ }_{6}$-PvCSP-Vivax-like) in the presence of the adjuvant poly(I-C). The immunizations were s.c. with three doses given 21 days apart according to the timeline shown in Fig. 3A. Serum IgG titers of antibodies against recombinant proteins representing each allelic form of PvCSP were measured as indicated. Mice immunized with 30 (inverted triangles) and 3 (squares) $\mu \mathrm{g} / \mathrm{dose} /$ mouse of the protein mixture responded equally well according to statistical comparisons (one-way ANOVA, no statistically significant difference). The results as expressed as means $\pm \mathrm{SD}(n=6)$.

nized with AdC68-PvCSP were higher than those of animals immunized with AdHu5-PvCSP $(P<0.05$; Fig. 6D).

To test whether recombinant adenovirus vectors could be used as priming immunogens in a heterologous prime-boost regimen, mice primed with the adenovirus vector were boosted s.c. 42 days after being primed with a protein mixture $\left(\mathrm{His}_{6}\right.$-PvCSP-VK210, His $_{6}$-PvCSP-VK247, and His $_{6}$-PvCSP-Vivax-like $3 \mu \mathrm{g} / \mathrm{dose} /$ mouse) in a formulation containing poly(I-C). Serum titers of IgG antibodies against all three allelic forms of PvCSP at day 63 in mice primed with AdC68-PvCSP (G5) or AdHu5-PvCSP (G6) and boosted with the protein mixture were significantly higher than the titers in control groups (G1, G2, G3, and G4) $(P<0.05$, Fig. 6D). No statistically significant differences were scored between mouse groups G5 and G6. These results provide evidence that priming with AdC68-PvCSP and AdHu5-PvCSP improves

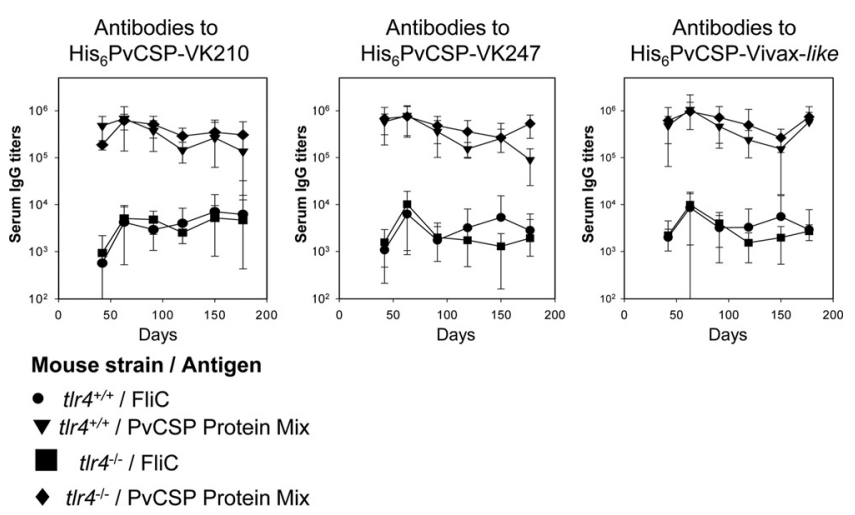

FIG 5 Induction of specific antibody responses in $t l r 4^{-1-}$ mice immunized with recombinant $P$. vivax $\mathrm{CS}$ antigens. Mice were immunized with three doses 21 days apart according to the protocol and timeline shown in Fig. 3A. The serum IgG responses against $P$. vivax CSP recombinant proteins were determined in $t l r 4^{+/+}$and $t l r 4^{-1-}$ mice immunized with formulations containing poly (I.C) and a PvCSP mixture ( His $_{6}-\mathrm{PvCSP}_{\mathrm{V}} \mathrm{CK} 210$, $\mathrm{His}_{6}-\mathrm{PvCSP}-\mathrm{VK} 247$, and $\mathrm{His}_{6}$-PvCSP-Vivax-like, $3 \mu \mathrm{g}$ /dose/mouse) or control recombinant FliC (10 $\mu \mathrm{g} /$ dose/mouse). $t \mathrm{lr} 4^{+1+}$ (inverted triangles) and $t r 4^{-1-}$ (diamonds) mice immunized with the PvCSP protein mixture responded well according to statistical comparisons (one-way ANOVA, no statistically significant difference). The results are expressed as means $\pm \mathrm{SD}(n=6)$. antibody responses upon subsequent immunization with the recombinant protein mixture.

These same mice described above received a second boost with a protein mixture in a formulation containing poly $(\mathrm{I} \cdot \mathrm{C})$ or with only adjuvant (control), as depicted in Fig. 7A. We followed the titers of specific serum IgGs against the different allelic forms of PvCSP for 178 days (Fig. 7B to D). Antibody titers in the different mouse groups immunized (boosted) twice with the recombinant protein mixture were equally high, and we did not detect statistically significant differences among groups G4, G5, and G6 (no statistically significant difference in all cases). Not only were the titers of anti-PvCSP-specific IgG after immunization equally high, but these immune responses were equally sustained, with high antibody titers persisting until day 178. Additionally, these responses did not differ significantly in terms of the subclasses of IgG that were elicited. The IgG1/IgG2c ratios of groups G4 and G5 were 0.95 and 1.125 , respectively.

These experiments allow us to conclude that recombinant adenoviruses expressing the PvCSP protein can successfully be used in a heterologous prime-boost protocol for vaccination. However, no significant impact on the serum IgG antibody titers was observed when we used either the homologous (protein-protein) or the heterologous (adenovirus-protein) regimen.

Specificity of the antibodies elicited by the homologous (protein-protein) or heterologous (adenoviruses/protein) regimen. We then studied the specificity of the antibodies against PvCSP. We selected for the sera from mice that had been immunized with the homologous (protein-protein) or heterologous (adenovirusprotein) regimen. To aid in the determination of the specificity of anti-PvCSP serum IgG antibodies, we used a number of recombinant proteins containing different portions of the antigen. Schematic representations of the recombinant proteins used and the antibody titers are depicted in Fig. 8A.

We found that antibodies from mice immunized with either the homologous or the heterologous regimen reacted with all of the recombinant proteins containing different portions of the three distinct allelic forms of the PvCSP antigen. These antibodies reacted with each repeat domain expressed as a part of a fusion protein in the C-terminal region of FliC. The mice also had significant titers of antibodies to a recombinant protein expressing the 
A

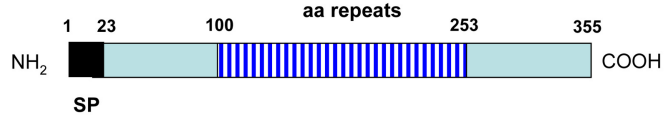

B

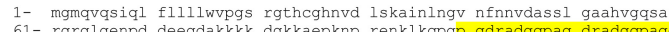
61- rgrglgenpd deegdakkkk dgkkaepknp renklkggp gdradgqpag dradgqpagd
$121-$ raagqagdr aagpagdra dgqpagdrad gqpagdrada pganqeggaa apganqegga
181-aapganqegg aaapganqe ggaaapganq eggaaapgan gegaaaang agnqpganga 241-gnqpgangag nqpgangagn qpgangagnq pgdraagqaa ggnaggqgqn negan

C

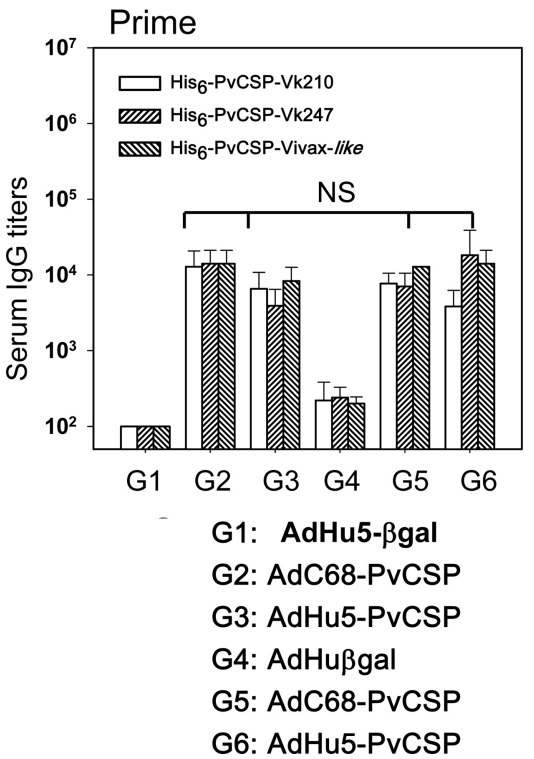

D

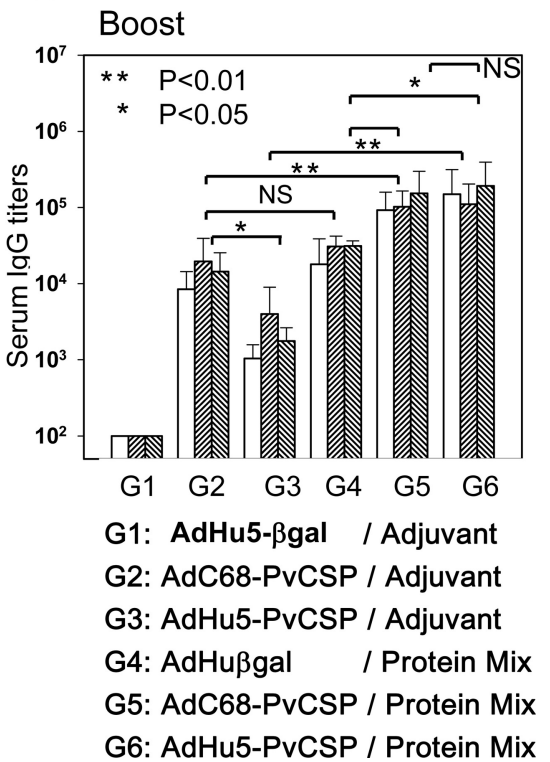

FIG 6 Induction of specific antibody responses in mice immunized with recombinant adenoviruses expressing $P$. vivax CSP as part of a heterologous primeboost regimen of vaccination. (A and B) Schematic representations and deduced amino acid (aa) sequences of the PvCSP-All-CSP-epitopes expressed by recombinant replication-defective simian or human adenovirus. (C) C57BL/6 mice were immunized i.m. at $2 \times 10^{7} \mathrm{PFU} / \mathrm{mouse}$ with AdHu5- $\beta$ gal (control), AdC68-PvCSP, or AdHu5-PvCSP. Serum titers of IgG against recombinant proteins of each allelic form of PvCSP were determined 21 days later as indicated. Mice immunized with AdC68-PvCS and AdHu5-PvCS responded equally well according to statistical comparisons (one-way ANOVA, no statistically significant difference $[\mathrm{NS}])$. The results are expressed as means $\pm \mathrm{SD}(n=5)$. (D) Mice were boosted s.c. 42 days after being primed with a formulation containing a protein mixture ( $\mathrm{His}_{6}-\mathrm{PvCSP}-\mathrm{VK} 210, \mathrm{His}_{6}-\mathrm{PvCSP}-\mathrm{VK} 247$, and $\mathrm{His}_{6}-\mathrm{PvCSP}-\mathrm{Vivax}-\mathrm{like}, 3 \mu \mathrm{g} /$ dose/mouse) in the presence of poly(I.C). The titers of specific antibodies to the different allelic forms of PvCSP were measured at day 63. According to statistical comparisons (one-way ANOVA, Tukey's HSD test), mice immunized with AdC68-PvCS and AdHu5-PvCS and boosted with a protein mixture (G5 and G6) had serum IgG antibody titers higher than those of the other groups, as shown.

$\mathrm{N}$ - and C-terminal regions but not the repeat region of the PvCSP antigen ( $\mathrm{His}_{6}$-PvCSP-No-repeats). As expected, however, the maximal reactivity was directed against the recombinant proteins containing all of PvCSP (Fig. 8B). We concluded that both the repeated and nonrepeated regions of PvCSP are targets for antibodies.

Finally, we determined whether sera from mice immunized with the homologous or heterologous immunization regimens reacted with $P$. vivax sporozoites in immunofluorescence assays. We observed that sera from both groups reacted to sporozoites of the $P$. vivax VK247 strain at a titer of 1:1,000 and in the case of the homologous immunization also at a titer of 1:10,000 (Fig. 9A). Antibody recognition was specific, as control sera from mice immunized with either the adjuvant poly(I.C) or AdHu5ß-gal/ poly (I.C) did not react, even at a 1:100 dilution (Fig. 9B). We also confirmed that sera from both groups of mice that were immunized with a formulation containing the protein mixture and poly $(\mathrm{I} \cdot \mathrm{C})$ reacted to sporozoites of the VK210 strain at a dilution of 1:10,000 (Fig. 9C).

Cell-mediated immune responses. To determine whether the vaccination protocols elicited $\mathrm{T}$ cell-mediated immune responses, we employed several methods of analyses. Spleen cells from mice immunized with either the homologous or the heterologous regimen were stimulated in vitro with recombinant proteins or overlapping synthetic peptides (15-mers) covering all of PvCSP. We measured IFN- $\gamma$ secretion by ELISPOT assay, by IC expression assays, and by detection of the cytokine in the supernatants. We also attempted to detect IL-2 and TNF by IC expression assays. Finally, we also used an in vivo cytotoxicity assay to estimate the presence of cytotoxic T lymphocytes in vaccinated mice (24). The results were negative in most cases independently of the timing of the analyses. Positive controls performed in parallel with experimental samples were consistently successful (data not shown).

Examples of these studies are depicted in Fig. 10 and 11. Splenic cells of mice immunized with the heterologous or homologous prime-and-boost regimen (described in Fig. 10A) were restimulated in culture with the recombinant proteins or synthetic peptides spanning the entire $\mathrm{N}$ - or $\mathrm{C}$-terminal region of $P$. vivax CSP (Fig. 10B). Significant differences in the frequencies of IFN- $\gamma^{+}$, $\mathrm{IL}_{-} 2^{+}$, or $\mathrm{TNF}-\mathrm{a}^{+}$in $\mathrm{CD} 4^{+}$or $\mathrm{CD}^{+}$cells in the experimental and control groups were not detected (Fig. 10C and D).

In parallel, these cells were subjected to ELISPOT assays. Like- 
A
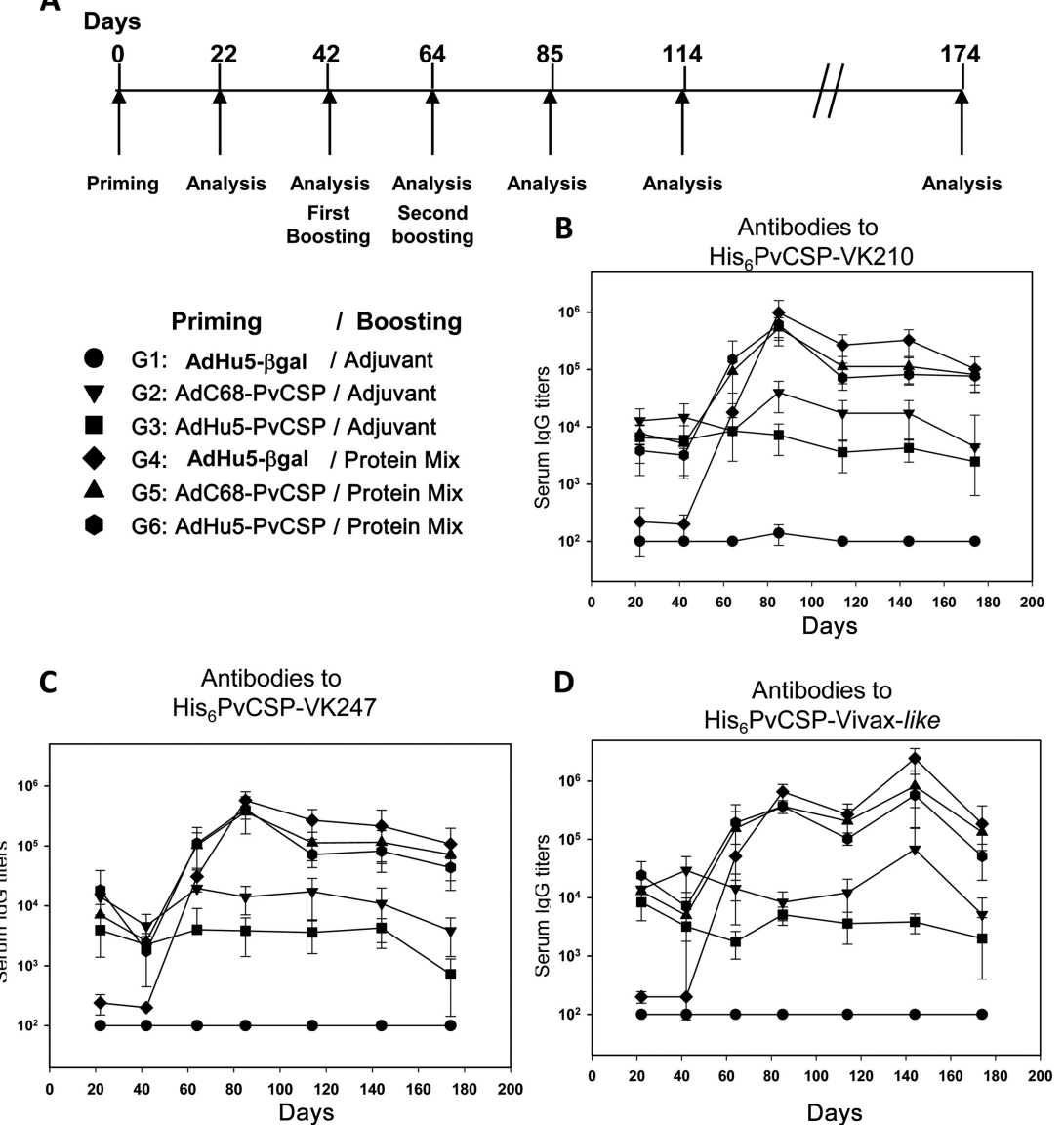

FIG 7 Induction of specific antibody responses in mice immunized with a heterologous (adenovirus-protein) or a homologous (protein-protein) vaccination regimen. (A) C57BL/6 mice were immunized with three doses of the indicated immunogens, and the antibody titers were analyzed according to the timeline shown. The first dose consisted of $2 \times 10^{7} \mathrm{PFU} /$ mouse of AdHu5- $\beta$ gal (control), AdC68-PvCSP, or AdHu5-PvCSP administered i.m. The first and second boosts

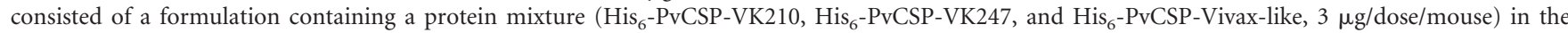
presence of poly(I.C). (B) Serum IgG titers against His ${ }_{6}$-PvCSP-VK210. (C) Serum IgG titers against His $6_{6}$-PvCSP-VK247. (D) Serum IgG titers against His $_{6}$-PvCSP-Vivax-like. Mice immunized with AdHu5-ßgal, AdC68-PvCS, and AdHu5-PvCS and boosted twice with a formulation containing a protein mixture in the presence of poly(I.C) (G4, G5, and G6) responded equally well according to statistical comparisons (one-way ANOVA, Tukey's HSD test, no statistically significant difference). The results are expressed as means $\pm \mathrm{SD}(n=5)$.

wise in the IC expression assay experiments, significant differences in the frequencies of IFN- $\gamma$-producing cells in the experimental and control groups were not detected (Fig. 11). One peptide only representing the repeat region of PvCSP of the $P$. vivax-like allele elicited a modest number of specific spot-forming cells. This peptide possibly represents a T cell epitope for C57BL/6 mice. We were able to obtain a stronger immune response by using IFA for immunization (data not shown). We concluded that although we were able to obtain high levels of antibody production following immunization, this response was not paralleled by high levels of T cell-mediated immunity.

\section{DISCUSSION}

In the present study, we tested whether recombinant proteins and adenovirus vectors could be used for the development a universal vaccine against $P$. vivax malaria. Using homologous or heterologous prime-boost immunization regimens, we were able to successfully elicit high titers of antibodies recognizing the three allelic forms of the PvCSP antigen. This malaria vaccine formulation could be used either as a protein mixture containing $\mathrm{His}_{6}$-PvCSP-
VK210, His $_{6}$-PvCSP-VK247, and His ${ }_{6}$-PvCSP-Vivax-like or a single recombinant protein containing epitopes of all three different allelic forms in a single fusion polypeptide $\left(\mathrm{His}_{6}\right.$-PvCSP-All-CSPepitopes). However, in the presence of $\operatorname{poly}(\mathrm{I} \cdot \mathrm{C})$, we found the protein mixture to be more immunogenic. This improved immunogenicity was not observed when the antigens were emulsified in CFA-IFA. The precise reasons for these differences are not clear. Nevertheless, these data highlight the importance of testing different formulations for vaccine selection.

Both homologous and heterologous vaccine protocols elicited specific antibody titers that were as high as those elicited following immunization with recombinant proteins emulsified in CFA-IFA. In addition, the antibody responses induced by both protocols were long lasting and significant titers were observed during the $\sim 180$-day period of the study. We have focused our efforts on inducing persistently high titers of specific antibodies against the CSP antigen. Antibodies against CSP have been described previously as a critical mechanism of antisporozoite immunity in diverse malaria models (reviewed in reference 1). On the basis of phase II human trials performed with the RTS,S/AS candidate 

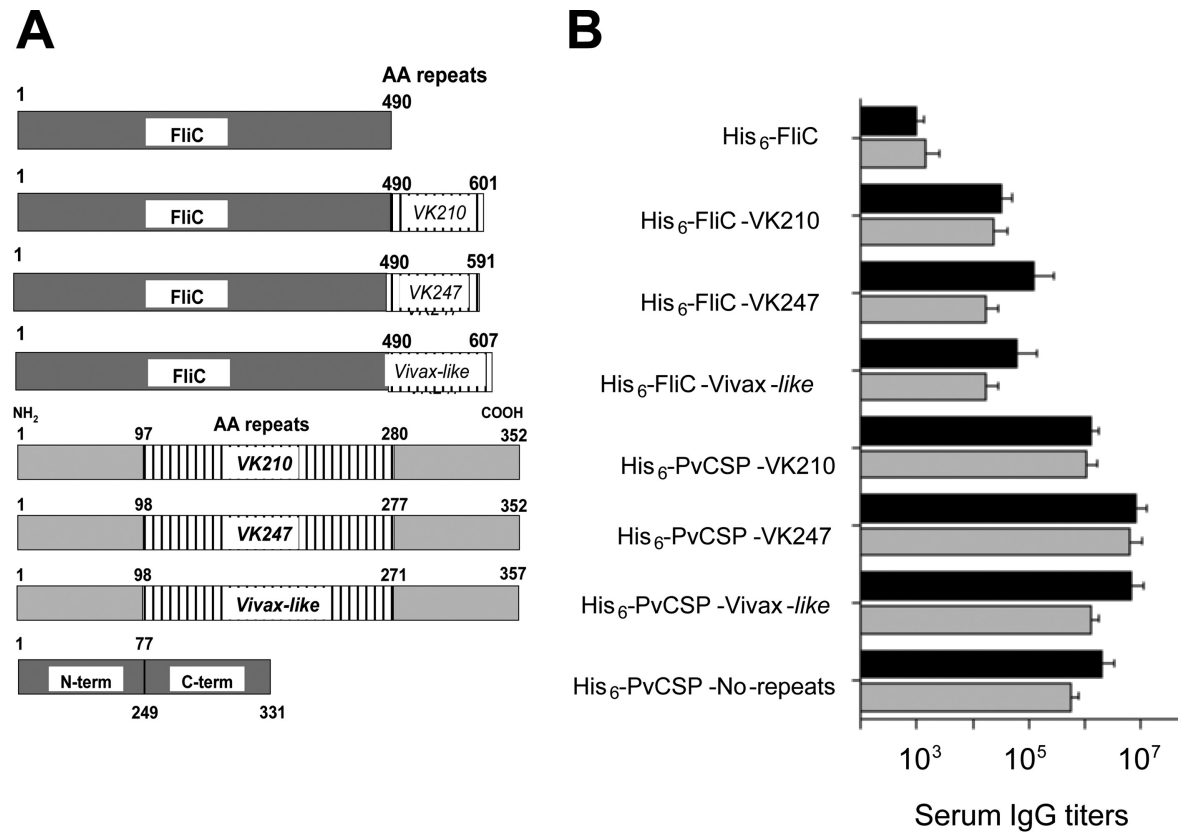

Prime-boost regimen

Homologous (protein/protein)

Heterologous (adenovirus/protein)

FIG 8 Specificity of the antibodies elicited by a homologous (protein-protein) or a heterologous (adenovirus-protein) immunization regimen. (A) Schematic representation of each recombinant protein used as a substrate bound to the plates in the ELISA. AA, amino acid; term, terminus. (B) Serum IgG antibodies from mice immunized with the homologous [protein-protein with poly(I-C)] or the heterologous (AdC68-PvCSP/protein mixture) regimen. The detailed immunization protocol is described in the legends to Fig. 3 (homologous) and 7 (heterologous). Sera were collected 2 weeks after the third dose was given. The results are expressed as means \pm S.D $(n=5)$.

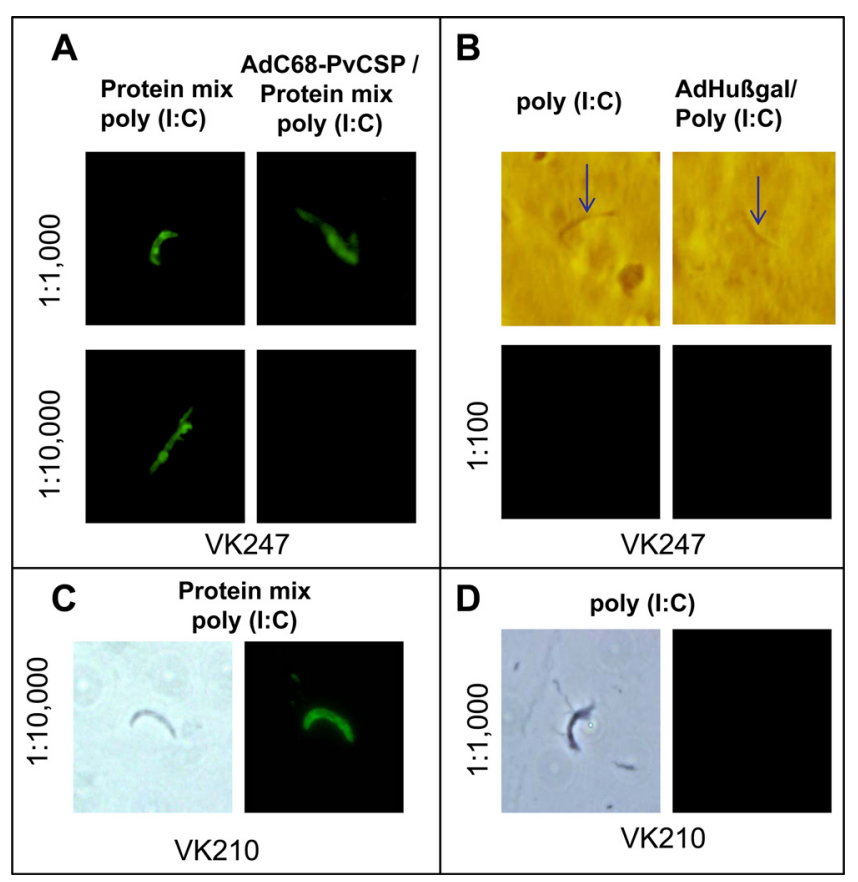

FIG 9 IIA for the recognition of the native protein PvCSP. Pools of sera from mice immunized with the homologous [protein-protein with poly $(\mathrm{I} \cdot \mathrm{C})$ ] and heterologous (AdC68-PvCSP/protein mixture) regimens were used. The detailed immunization protocol is described in the legends to Fig. 3 (homologous) and 7 (heterologous). vaccine, antibodies continue to be the factor that strongly correlates with sterile immunity. In RTS,S/AS-vaccinated individuals who were experimentally challenged with $P$. falciparum sporozoites by mosquito bite, vaccine efficacy was correlated with higher titers of antibodies against CSP and sporozoites (2). Similarly, phase II vaccine trials performed with African children reported a nonlinear relationship between the titers of antibodies against CSP and a lower incidence of malaria (25).

Several antiparasitic mechanisms have been described that are mediated by antibodies against CSP. First, antibodies reduce the sporozoite inoculum and parasite viability during a mosquito bite. With an experimental rodent model, it has been shown that an immune complex formed during the mosquito bite reduces the number of sporozoites deposited during feeding (26). The parasites injected into immune mice were immobilized and not capable of invading dermal blood vessels (26). When the sporozoites are inoculated intravenously, thus bypassing the skin, anti-CSP antibodies efficiently block the infection of hepatocytes (26). The inhibition of hepatocyte infection may be due to a reduction of the sporozoites' ability to move or attach to hepatocytes (27-29).

The specificity of the inhibitory antibodies for the malaria CSP antigen was initially assigned to the central repeat domain (30). In the case of $P$. vivax, this postulate was recently confirmed by the use of a transgenic $P$. berghei sporozoite expressing the repeat domain from the VK210 strain. In vivo parasite infectivity in mice was drastically inhibited by the passive transfer of a MAb against the VK210 repeats (31). These observations further confirm sim- 
A
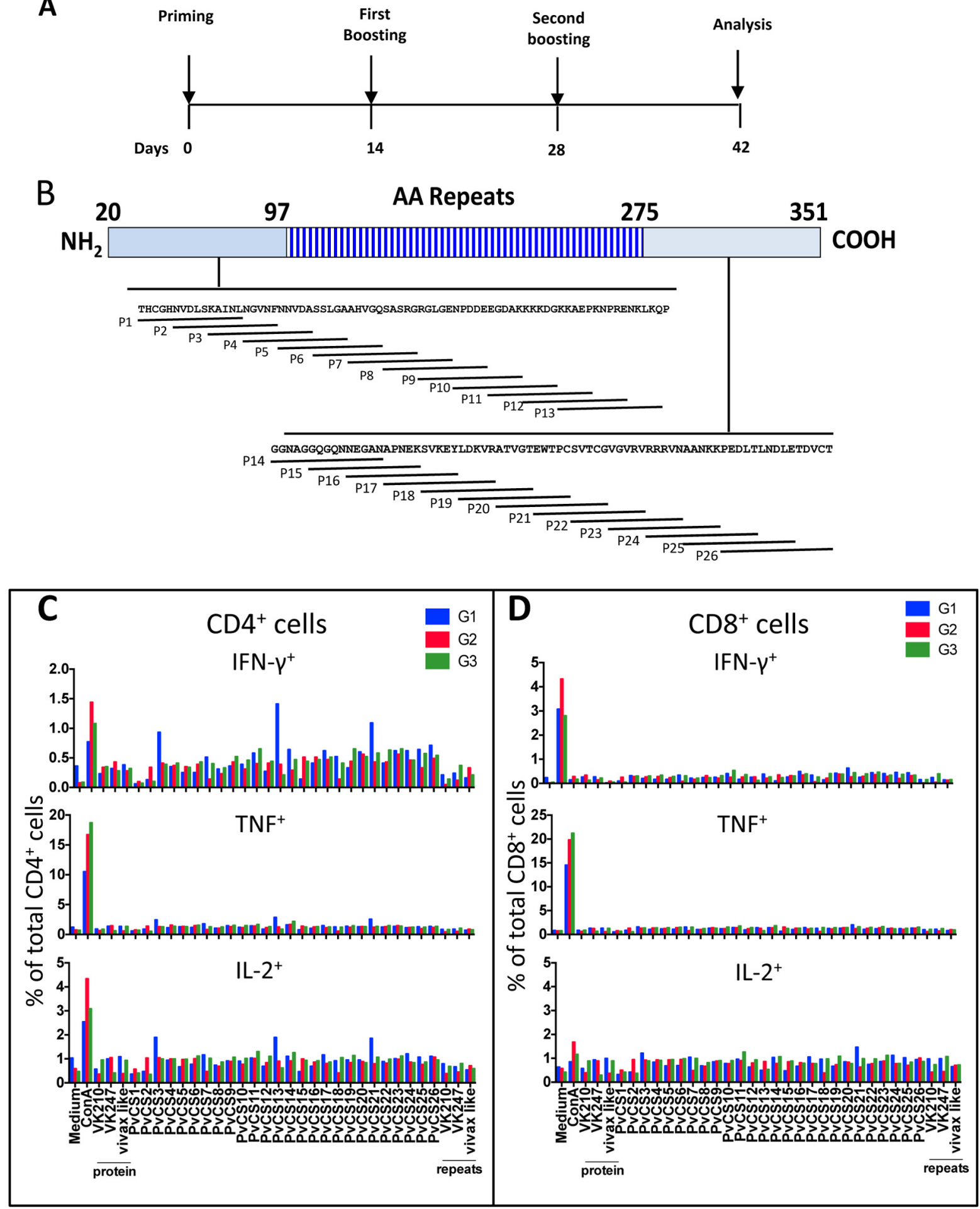

FIG 10 Cell-mediated immunity of mice immunized with recombinant $P$. vivax CSP antigens. (A) C57BL/6 mice were immunized with three doses given 14 days apart, and IC expression assays were performed according to the timeline shown. (B) Twenty-six overlapping peptides spanning the entire sequence of the $\mathrm{N}$ or $\mathrm{C}$ terminus of PvCSP were used to stimulate splenocytes. AA, amino acid. (C and D) G1 mice (control) were primed i.m. at $2 \times 10^{8} \mathrm{PFU} / \mathrm{mouse}$ with AdHu5-b-gal and boosted s.c. twice with poly(I.C). G2 mice were primed i.m. at $2 \times 10^{8} \mathrm{PFU} /$ mouse with AdC68-PvCSP and boosted twice with a protein

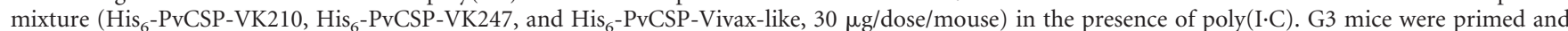
boosted with a protein mixture ( $\mathrm{His}_{6}-\mathrm{PvCSP}-\mathrm{VK} 210, \mathrm{His}_{6}-\mathrm{PvCSP}-\mathrm{VK} 247$, and $\left.\mathrm{His}_{6}-\mathrm{PvCSP}-\mathrm{Vivax}-\mathrm{like}, 30 \mu \mathrm{g} / \mathrm{dose} / \mathrm{mouse}\right)$. Fourteen days later, splenic cells of these mice were cultured in the presence of anti-CD28 antibody, monensin, and brefeldin A with or without the peptides or recombinant proteins or ConA as indicated. The PvCS-VK210, PvCS-VK247, and PvCS-Vivax-like peptides represent the repeat regions of the allelic variants. After $12 \mathrm{~h}$, cells were stained with anti-CD4, anti-CD8, anti-IL-2, anti-IFN- $\gamma$, and anti-TNF- $\alpha$ antibodies. The results are expressed as the total frequency $(\%)$ of CD4 ${ }^{+}$or CD8 ${ }^{+}$cells stained for each molecule. Results were obtained from pooled cells from five mice. 


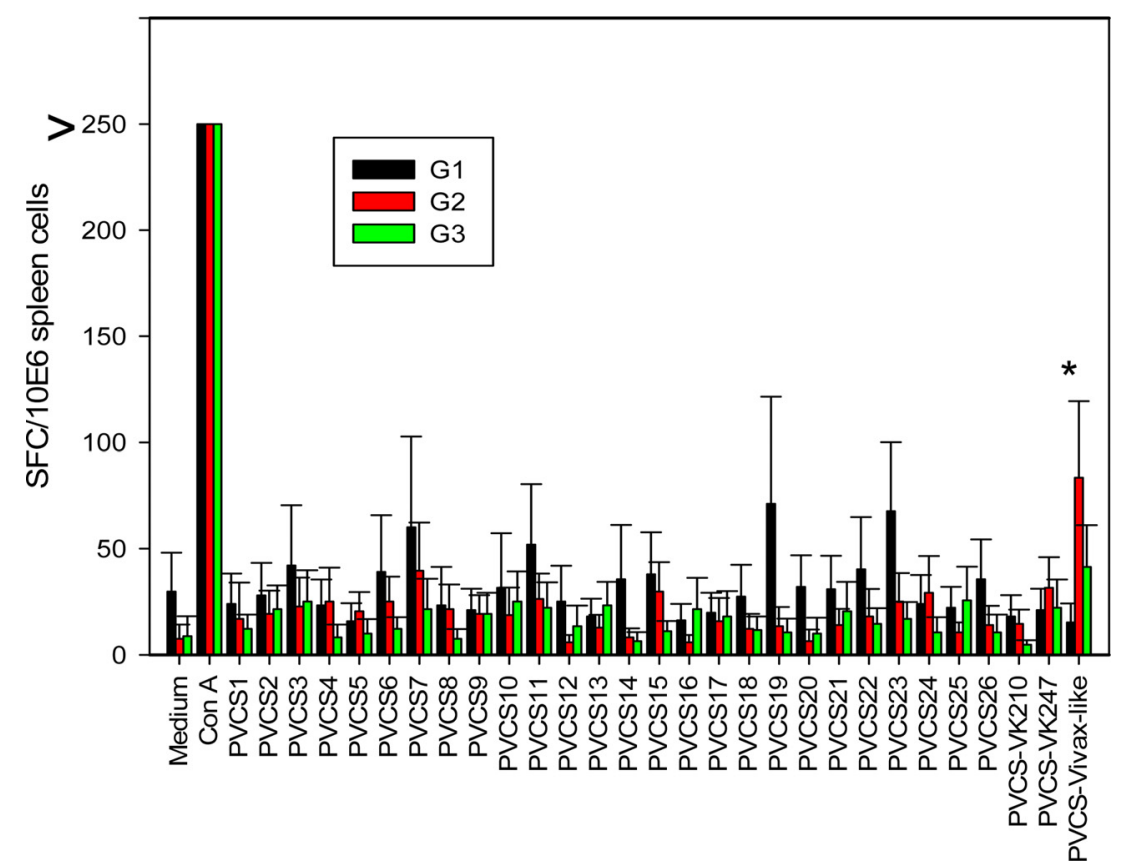

FIG 11 Cell-mediated immunity of mice immunized with recombinant $P$. vivax CSP antigens. C57BL/6 mice were immunized as described in the legend to Fig. 10. Splenic cells of these mice were cultured in the presence or absence of the peptides or ConA, as indicated. The PvCS-VK210, PvCS-VK247, and PvCS-Vivaxlike peptides represent the repeat regions of the allelic variants. After $48 \mathrm{~h}$, IFN- $\gamma$-secreting cells (spot-forming cells [SFC]) were estimated by ELISPOT assay. The results are expressed as the frequency of SFC per $10^{6}$ spleen cells obtained from pooled cells of five mice. The asterisk denotes a statistically significant difference $(P<0.01)$.

ilar data from other parasites, which showed that the repeat domain of CSP is a target of neutralizing antibodies.

In addition to the repeat domain, in the case of the P. vivax CSP protein, humans immunized with long synthetic peptides representing the $\mathrm{N}$ and $\mathrm{C}$ termini of CSP generated antibodies that can inhibit sporozoite invasion in vitro (32). These results indicate that vaccines that elicit high titers of antibodies against different regions of PvCSP should be pursued. In the vaccination protocols described here, we generated high titers of antibodies against all three allelic forms of the PvCSP protein that reacted with different domains of the protein.

IIA analyses with sporozoites of $P$. vivax strains VK210 and VK247 demonstrated that these vaccine-elicited antibodies can recognize the native CSP on sporozoites. However, the ability of these antibodies to neutralize sporozoites in vivo has yet to be evaluated with transgenic parasites (31).

In addition to antibodies, $\mathrm{CD} 4^{+}$and $\mathrm{CD} 8^{+} \mathrm{T}$ cells have been described as powerful mediators of preerythrocytic stage elimination in rodent experimental models (reviewed in references 3238). In fact, a number of $\mathrm{T}$ cell epitopes have been described by us and others in CSP (reviewed in references 32-38). The results obtained with the mouse model have fueled a number of human trials with plasmid DNA, recombinant viruses, and, more recently, radiation-attenuated sporozoites as vaccine formulations. Unfortunately, in spite of the enthusiasm generated by the mouse model, $\mathrm{T}$ cell-based vaccines against preerythrocytic stages of malaria have provided sterile immunity against infection with $P$. falciparum to only a few vaccinated individuals to date (39-44). The precise reason for this failure is not clear. Perhaps the frequency of $\mathrm{T}$ cells generated by the different vaccine protocols was not sufficient, as these $\mathrm{T}$ cells have to patrol the entire human liver. In fact, since the first reports of adoptive $\mathrm{T}$ cell transfer more than 20 years ago, it has been known that large numbers of multifunctional effector $\mathrm{CD} 8{ }^{+} \mathrm{T}$ cells must be transferred to a mouse to provide sterile immunity (45-47). More recently, elegant studies using the mouse model have confirmed that a large number of multifunctional effector $\mathrm{CD} 8^{+} \mathrm{T}$ cells must be generated to provide sterile protection (48).

The development of candidate vaccines against preerythrocytic stages of $P$. vivax has been performed mostly with preclinical immunization models (mice and nonhuman primates; 49-51). Only three phase I clinical trials of recombinant proteins or long synthetic peptides against this parasite have been reported (52-54). The reagents and protocols described in the present study, when used in homologous or heterologous regimens, can be immediately transferred to humans. Poly(ICLC) is currently being tested for human use (23). Similarly, recombinant human replicationdefective adenoviruses of serotype 5 are being used in multiple human trials (55-58).

The fact that we did not detect significant differences in antibody titers or cell-mediated immunity when using either the homologous or the heterologous vaccination regimen should not be considered a failure of the second. Considering that our ultimate goal is human trials, the use of a recombinant adenovirus vector may still improve the immune response by the presence of human T-cell epitopes. On the basis of that, we believe that the formulations described here provide new $P$. vivax vaccine candidates with universal coverage that warrant further clinical testing.

\section{ACKNOWLEDGMENTS}

This work was supported by grants from the Fundação de Amparo à Pesquisa do Estado de São Paulo (FAPESP Proc. 2009/15432-4 and Proc. 
2012/13032-5), the National Institute for Vaccine Development and Technology (CNPq-INCTV; CNPq Universal Proc. 471087/2013-0), and PNPD and fellowships from CNPq (M.M.R., I.S.S., A.G.C., OBR), FAPESP (M.T.A.L., C.A.T., J.E.), and CAPES (L.H.T.).

We are in debt to Kim Lee Sim and Stephen L. Hoffman of Sanaria Inc. for providing $P$. vivax sporozoite slides. We thank Keyna M. Soares for helping during the experiment shown in Fig. 6.

L.H.T., C.A.T., M.O.L., O.B.R., I.S.S., R.S.N., H.E., V.N. and M.M.R. are named inventors on patent applications entitled "Plasmodium vivax vaccine compositions," file reference no.:27522-0201WO1.

\section{REFERENCES}

1. Cohen J, Nussenzweig V, Nussenzweig R, Vekemans J, Leach A. 2010. From the circumsporozoite protein to the RTS, S/AS candidate vaccine. Hum. Vaccin. 6:90-96. http://dx.doi.org/10.4161/hv.6.1.9677.

2. White MT, Bejon P, Olotu A, Griffin JT, Riley EM, Kester EK, Ockenhouse CF, Ghani AC. 2013. The relationship between RTS,S vaccineinduced antibodies, $\mathrm{CD} 4{ }^{+} \mathrm{T}$ cell responses and protection against Plasmodium falciparum infection. PLoS One 8:e61395. http://dx.doi.org/10 .1371/journal.pone.0061395.

3. Agnandji ST, Lell B, Soulanoudjingar SS, Fernandes JF, Abossolo BP, Conzelmann C, Methogo BG, Doucka Y, Flamen A, Mordmüller B, Issifou S, Kremsner PG, Sacarlal J, Aide P, Lanaspa M, Aponte JJ, Nhamuave A, Quelhas D, Bassat Q, Mandjate S, Macete E, Alonso P, Abdulla S, Salim N, Juma O, Shomari M, Shubis K, Machera F, Hamad AS, Minja R, Mtoro A, Sykes A, Ahmed S, Urassa AM, Ali AM, Mwangoka G, Tanner M, Tinto H, D’Alessandro U, Sorgho H, Valea I, Tahita MC, Kaboré W, Ouédraogo S, Sandrine Y, Guiguemdé RT, Ouédraogo JB, Hamel MJ, Kariuki S, Odero C, Oneko M, Otieno K, Awino N, Omoto J, Williamson J, Muturi-Kioi V, Laserson KF, Slutsker L, Otieno W, Otieno L, Nekoye O, Gondi S, Otieno A, Ogutu B, Wasuna R, Owira V, Jones D, Onyango AA, Njuguna P, Chilengi R, Akoo P, Kerubo C, Gitaka J, Maingi C, Lang T, Olotu A, Tsofa B, Bejon P, Peshu N, Marsh K, Owusu-Agyei S, Asante KP, Osei-Kwakye K, Boahen O, Ayamba S, Kayan K, Owusu-Ofori R, Dosoo D, Asante I, Adjei G, Adjei G, Chandramohan D, Greenwood B, Lusingu J, Gesase S, Malabeja A, Abdul O, Kilavo H, Mahende C, Liheluka E, Lemnge M, Theander T, Drakeley C, Ansong D, Agbenyega T, Adjei S, Boateng HO, Rettig T, Bawa J, Sylverken J, Sambian D, Agyekum A, Owusu L, Martinson F, Hoffman I, Mvalo T, Kamthunzi P, Nkomo R, Msika A, Jumbe A, Chome N, Nyakuipa D, Chintedza J, Ballou WR, Bruls M, Cohen J, Guerra Y, Jongert E, Lapierre D, Leach A, Lievens M, OforiAnyinam O, Vekemans J, Carter T, Leboulleux D, Loucq C, Radford A, Savarese B, Schellenberg D, Sillman M, Vansadia P, RTS,S Clinical Trials Partnership. 2011. First results of phase 3 trial of RTS,S/AS01 malaria vaccine in African children. N. Engl. J. Med. 365:1863-1875. http: //dx.doi.org/10.1056/NEJMoa1102287.

4. Agnandji ST, Lell B, Fernandes JF, Abossolo BP, Methogo BG, RTS,S Clinical Trials Partnership. 2012. A phase 3 trial of RTS,S/AS01 malaria vaccine in African infants. N. Engl. J. Med. 367:2284-2295. http://dx.doi .org/10.1056/NEJMoa1208394.

5. Guerra CA, Howes RE, Patil AP, Gething PW, Van Boeckel TP, Temperley WH, Kabaria CW, Tatem AJ, Manh BH, Elyazar IR, Baird JK, Snow RW, Hay SI. 2010. The international limits and population at risk of Plasmodium vivax transmission in 2009. PLoS Negl. Trop. Dis. 4:e774. http://dx.doi.org/10.1371/journal.pntd.0000774.

6. Arnot DE, Barnwell JW, Tam JP, Nussenzweig V, Nussenzweig RS, Enea V. 1985. Circumsporozoite protein of Plasmodium vivax: gene cloning and characterization of the immunodominant epitope. Science 230: 815-818. http://dx.doi.org/10.1126/science.2414847.

7. Rosenberg R, Wirtz RA, Lanar DE, Sattabongkot J, Hall T, Waters AP, Prasittisuk C. 1989. Circumsporozoite protein heterogeneity in the human malaria parasite Plasmodium vivax. Science 245:973-976. http://dx .doi.org/10.1126/science.2672336.

8. Qari SH, Shi YP, Povoa MM, Alpers MP, Deloron P, Murphy GS, Harjosuwarno S, Lal AA. 1993. Global occurrence of Plasmodium vivaxlike human malaria parasite. J. Infect. Dis. 168:1485-1489. http://dx.doi .org/10.1093/infdis/168.6.1485.

9. de Arruda M, Souza RC, Veiga ME, Ferreira AF, Zimmerman RH. 1998. Prevalence of Plasmodium vivax variants VK247 and P. vivax-like human malaria: a retrospective study in indigenous Indian populations of the
Amazon region of Brazil. Trans. R. Soc. Trop. Med. Hyg. 92:628. http://dx .doi.org/10.1016/S0035-9203(98)90788-X.

10. Marrelli MT, Branquinho MS, Hoffmann EH, Taipe-Lagos CB, Natal D, Kloetzel JK. 1998. Correlation between positive serology for Plasmodium vivax-like/Plasmodium simiovale malaria parasites in the human and anopheline populations in the State of Acre, Brazil. Trans. R. Soc. Trop. Med. Hyg. 92:149-151. http://dx.doi.org/10.1016/S0035 -9203(98)90723-4.

11. Bonilla JA, Validum L, Cummings R, Palmer CJ. 2006. Genetic diversity of Plasmodium vivax Pvcsp and Pvmsp1 in Guyana, South America. Am. J. Trop. Med. Hyg. 75:830-835. http://www.ajtmh.org/content/75/5/830 .full.pdf + html.

12. Gopinath R, Wongsrichanalai C, Cordón-Rosales C, Mirabelli L, Kyle D, Kain KC. 1994. Failure to detect a Plasmodium vivax-like malaria parasite in globally collected blood samples. J. Infect. Dis. 170:1630-1633. http://dx.doi.org/10.1093/infdis/170.6.1630.

13. Takeuchi O, Hoshino K, Kawai T, Sanjo H, Takada H, Ogawa T, Takeda K, Akira S. 1999. Differential roles of TLR2 and TLR4 in recognition of gram-negative and gram-positive bacterial cell wall components. Immunity 11:443-451. http://dx.doi.org/10.1016/S1074 -7613(00)80119-3.

14. Leal MT, Ariza Camacho AG, Teixeira LH, Bargieri DY, Soares IS, Tararam CA, Rodrigues MM. 2013. Immunogenicity of recombinant proteins consisting of Plasmodium vivax circumsporozoite protein allelic variant-derived epitopes fused with Salmonella Typhimurium flagellin. Clin. Vaccine Immunol. 20:1418-1425. http://dx.doi.org/10.1128/CVI .00312-13.

15. Bargieri DY, Rosa DS, Braga CJ, Carvalho BO, Costa FT, Espíndola NM, Vaz AJ, Soares IS, Ferreira LC, Rodrigues MM. 2008. New malaria vaccine candidates based on the Plasmodium vivax merozoite surface protein- 1 and the TLR-5 agonist Salmonella Typhimurium FliC flagellin. Vaccine 26:6132-6142. http://dx.doi.org/10.1016/j.vaccine.2008.08.070.

16. Zhou D, Zhou X, Bian A, Li H, Chen H, Small JC, Li Y, Giles-Davis W, Xiang Z, Ertl HC. 2010. An efficient method of directly cloning chimpanzee adenovirus as a vaccine vector. Nat. Protoc. 5:1775-1785. http://dx .doi.org/10.1038/nprot.2010.134.

17. Gupta RK, Siber GR. 1995. Method for quantitation of IgG subclass antibodies in mouse serum by enzyme-linked immunosorbent assay. J. Immunol. Methods 181:75-81. http://dx.doi.org/10.1016/0022 -1759(94)00331-P.

18. Nardin EH, Nussenzweig V, Nussenzweig RS, Collins WE, Harinasuta KT, Tapchaisri P, Chomcharn Y. 1982. Circumsporozoite proteins of human malaria parasites Plasmodium falciparum and Plasmodium vivax. J. Exp. Med. 156:20-30. http://dx.doi.org/10.1084/jem.156.1.20.

19. de Alencar BC, Persechini PM, Haolla FA, de Oliveira G, Silvério JC, Lannes-Vieira J, Machado AV, Gazzinelli RT, Bruna-Romero O, Rodrigues MM. 2009. Perforin and gamma interferon expression are required for $\mathrm{CD}^{+}$and $\mathrm{CD} 8^{+} \mathrm{T}$-cell-dependent protective immunity against a human parasite, Trypanosoma cruzi, elicited by heterologous plasmid DNA prime-recombinant adenovirus 5 boost vaccination. Infect. Immun. 77:4383-4395. http://dx.doi.org/10.1128/IAI.01459-08.

20. Vasconcelos JR, Bruña-Romero O, Araújo AF, Dominguez MR, Ersching J, de Alencar BC, Machado AV, Gazzinelli RT, Bortoluci KR, Amarante-Mendes GP, Lopes MF, Rodrigues MM. 2012. Pathogeninduced proapoptotic phenotype and high CD95 (Fas) expression accompany a suboptimal CD8(+) T-cell response: reversal by adenoviral vaccine. PLoS Pathog. 8:e1002699. http://dx.doi.org/10.1371/journal.ppat .1002699 .

21. Chattopadhyay R, Velmurugan S, Chakiath C, Andrews Donkor L, Milhous W, Barnwell JW, Collins WE, Hoffman SL. 2010. Establishment of an in vitro assay for assessing the effects of drugs on the liver stages of Plasmodium vivax malaria. PLoS One 5:e14275. http://dx.doi.org/10 .1371 /journal.pone.0014275.

22. Solarte Y, Manzano MR, Rocha L, Hurtado H, James MA, ArévaloHerrera M, Herrera S. 2011. Plasmodium vivax sporozoite production in Anopheles albimanus mosquitoes for vaccine clinical trials. Am. J. Trop. Med. Hyg. 84(2 Suppl):28-34. http://dx.doi.org/10.4269/ajtmh.2011.09 -0499 .

23. Caskey M, Lefebvre F, Filali-Mouhim A, Cameron MJ, Goulet JP, Haddad EK, Breton G, Trumpfheller C, Pollak S, Shimeliovich I, Duque-Alarcon A, Pan L, Nelkenbaum A, Salazar AM, Schlesinger SJ, Steinman RM, Sékaly RP. 2011. Synthetic double-stranded RNA induces 
innate immune responses similar to a live viral vaccine in humans. J. Exp. Med. 208:2357-2366. http://dx.doi.org/10.1084/jem.20111171.

24. Clemente T, Dominguez MR, Vieira NJ, Rodrigues MM, AmaranteMendes GP. 2013. In vivo assessment of specific cytotoxic T lymphocyte killing. Methods 61:105-109. http://dx.doi.org/10.1016/j.ymeth.2013.02 .007

25. Olotu A, Lusingu J, Leach A, Lievens M, Vekemans J, Msham S, Lang T, Gould J, Dubois MC, Jongert E, Vansadia P, Carter T, Njuguna P, Awuondo KO, Malabeja A, Abdul O, Gesase S, Mturi N, Drakeley CJ, Savarese B, Villafana T, Lapierre D, Ballou WR, Cohen J, Lemnge MM, Peshu N, Marsh K, Riley EM, von Seidlein L, Bejon P. 2011. Efficacy of RTS,S/AS01E malaria vaccine and exploratory analysis on anti-circumsporozoite antibody titres and protection in children aged 5-17 months in Kenya and Tanzania: a randomised controlled trial. Lancet Infect. Dis. 11:102-109. http://dx.doi.org/10.1016/S1473 -3099(10)70262-0.

26. Kebaier C, Voza T, Vanderberg J. 2009. Kinetics of mosquito-injected Plasmodium sporozoites in mice: fewer sporozoites are injected into sporozoite-immunized mice. PLoS Pathog. 5:e1000399. http://dx.doi.org /10.1371/journal.ppat.1000399.

27. Lacroix C, Ménard R. 2008. TRAP-like protein of Plasmodium sporozoites: linking gliding motility to host-cell traversal. Trends Parasitol. 24: 431-434. http://dx.doi.org/10.1016/j.pt.2008.07.003.

28. Coppi A, Natarajan R, Pradel G, Bennett BL, James ER, Roggero MA, Corradin G, Persson C, Tewari R, Sinnis P. 2011. The malaria circumsporozoite protein has two functional domains, each with distinct roles as sporozoites journey from mosquito to mammalian host. J. Exp. Med. 208:341-356. http://dx.doi.org/10.1084/jem.20101488.

29. Montagna GN, Matuschewski K, Buscaglia CA. 2012. Plasmodium sporozoite motility: an update. Front. Biosci. 17:726-744. http://dx.doi .org/10.2741/3954.

30. Yoshida N, Nussenzweig RS, Potocnjak P, Nussenzweig V, Aikawa M. 1980. Hybridoma produces protective antibodies directed against the sporozoite stage of malaria parasite. Science 207:71-73. http://dx.doi.org /10.1126/science.6985745.

31. Espinosa DA, Yadava A, Angov E, Maurizio PL, Ockenhouse CF, Zavala F. 2013. Development of a chimeric Plasmodium berghei strain expressing the repeat region of the $P$. vivax circumsporozoite protein for in vivo evaluation of vaccine efficacy. Infect. Immun. 81:2882-2887. http://dx.doi .org/10.1128/IAI.00461-13.

32. Arévalo-Herrera M, Soto L, Perlaza BL, Céspedes N, Vera O, Lenis AM, Bonelo A, Corradin G, Herrera S. 2011. Antibody-mediated and cellular immune responses induced in naive volunteers by vaccination with long synthetic peptides derived from the Plasmodium vivax circumsporozoite protein. Am. J. Trop. Med. Hyg. 84(2 Suppl):35-42. http://dx.doi.org/10 .4269/ajtmh.2011.09-0507.

33. Nardin EH, Nussenzweig RS. 1993. T cell responses to pre-erythrocytic stages of malaria: role in protection and vaccine development against preerythrocytic stages. Annu. Rev. Immunol. 11:687-727. http://dx.doi.org /10.1146/annurev.iy.11.040193.003351.

34. Schwenk RJ, Richie TL. 2011. Protective immunity to pre-erythrocytic stage malaria. Trends Parasitol. 27:306-314. http://dx.doi.org/10.1016/j .pt.2011.02.002.

35. Douradinha B, Doolan DL. 2011. Harnessing immune responses against Plasmodium for rational vaccine design. Trends Parasitol. 27:274-283. http://dx.doi.org/10.1016/j.pt.2011.01.002.

36. Sinnis P, Zavala F. 2012. The skin: where malaria infection and the host immune response begin. Semin. Immunopathol. 34:787-792. http://dx .doi.org/10.1007/s00281-012-0345-5

37. Vaughan AM, Kappe SH. 2012. Malaria vaccine development: persistent challenges. Curr. Opin. Immunol. 24:324-331. http://dx.doi.org/10.1016 /j.coi.2012.03.009.

38. Soares IS, Françoso KS, Jampaulo VO, Rodrigues MM. 2012. CD8(+) T-cell-mediated immunity against malaria: a novel heterologous primeboost strategy. Expert Rev. Vaccines 11:1039-1041. http://dx.doi.org/10 1586/erv.12.82

39. Dunachie SJ, Walther M, Epstein JE, Keating S, Berthoud T, Andrews L, Andersen RF, Bejon P, Goonetilleke N, Poulton I, Webster DP, Butcher G, Watkins K, Sinden RE, Levine GL, Richie TL, Schneider J, Kaslow D, Gilbert SC, Carucci DJ, Hill AV. 2006. A DNA primemodified vaccinia virus Ankara boost vaccine encoding thrombospondinrelated adhesion protein but not circumsporozoite protein partially protects healthy malaria-naive adults against Plasmodium falciparum sporozoite challenge. Infect. Immun. 74:5933-5942. http://dx.doi.org/10 .1128/IAI.00590-06

40. Epstein JE, Tewari K, Lyke KE, Sim BK, Billingsley PF, Laurens MB, Gunasekera A, Chakravarty S, James ER, Sedegah M, Richman A, Velmurugan S, Reyes S, Li M, Tucker K, Ahumada A, Ruben AJ, Li T, Stafford R, Eappen AG, Tamminga C, Bennett JW, Ockenhouse CF, Murphy JR, Komisar J, Thomas N, Loyevsky M, Birkett A, Plowe CV, Loucq C, Edelman R, Richie TL, Seder RA, Hoffman SL. 2011. Live attenuated malaria vaccine designed to protect through hepatic $\mathrm{CD} 8{ }^{+} \mathrm{T}$ cell immunity. Science 334:475-480. http://dx.doi.org/10.1126/science .1211548 .

41. Sedegah M, Tamminga C, McGrath S, House B, Ganeshan H, Lejano J, Abot E, Banania GJ, Sayo R, Farooq F, Belmonte M, Manohar N, Richie NO, Wood C, Long CA, Regis D, Williams FT, Shi M, Chuang I, Spring M, Epstein JE, Mendoza-Silveiras J, Limbach K, Patterson NB, Bruder JT, Doolan DL, King CR, Soisson L, Diggs C, Carucci D, Dutta S, Hollingdale MR, Ockenhouse CF, Richie TL. 2011. Adenovirus 5-vectored P. falciparum vaccine expressing CSP and AMA1. Part A: safety and immunogenicity in seronegative adults. PLoS One 6:e24586. http://dx.doi .org/10.1371/journal.pone.0024586.

42. Tamminga C, Sedegah M, Regis D, Chuang I, Epstein JE, Spring M, Mendoza-Silveiras J, McGrath S, Maiolatesi S, Reyes S, Steinbeiss V, Fedders C, Smith K, House B, Ganeshan H, Lejano J, Abot E, Banania GJ, Sayo R, Farooq F, Belmonte M, Murphy J, Komisar J, Williams J, Shi M, Brambilla D, Manohar N, Richie NO, Wood C, Limbach K, Patterson NB, Bruder JT, Doolan DL, King CR, Diggs C, Soisson L, Carucci D, Levine G, Dutta S, Hollingdale MR, Ockenhouse CF, Richie TL. 2011. Adenovirus-5-vectored P. falciparum vaccine expressing CSP and AMA1. Part B: safety, immunogenicity and protective efficacy of the CSP component. PLoS One 6:e25868. http://dx.doi.org/10.1371/journal .pone.0025868

43. Richie TL, Charoenvit Y, Wang R, Epstein JE, Hedstrom RC, Kumar S, Luke TC, Freilich DA, Aguiar JC, Sacci JB, Jr, Sedegah M, Nosek RA, Jr, De La Vega P, Berzins MP, Majam VF, Abot EN, Ganeshan H, Richie NO, Banania JG, Baraceros MF, Geter TG, Mere R, Bebris L, Limbach K, Hickey BW, Lanar DE, Ng J, Shi M, Hobart PM, Norman JA, Soisson LA, Hollingdale MR, Rogers WO, Doolan DL, Hoffman SL. 2012. Clinical trial in healthy malaria-naïve adults to evaluate the safety, tolerability, immunogenicity and efficacy of MuStDO5, a five-gene, sporozoite/ hepatic stage Plasmodium falciparum DNA vaccine combined with escalating dose human GM-CSF DNA. Hum. Vaccin. Immunother. 8:15641584. http://dx.doi.org/10.4161/hv.22129.

44. Chuang I, Sedegah M, Cicatelli S, Spring M, Polhemus M, Tamminga C, Patterson N, Guerrero M, Bennett JW, McGrath S, Ganeshan H, Belmonte M, Farooq F, Abot E, Banania JG, Huang J, Newcomer R, Rein L, Litilit D, Richie NO, Wood C, Murphy J, Sauerwein R, Hermsen CC, McCoy AJ, Kamau E, Cummings J, Komisar J, Sutamihardja A, Shi M, Epstein JE, Maiolatesi S, Tosh D, Limbach K, Angov E, BergmannLeitner E, Bruder JT, Doolan DL, King CR, Carucci D, Dutta S, Soisson L, Diggs C, Hollingdale MR, Ockenhouse CF, Richie TL. 2013. DNA prime/adenovirus boost malaria vaccine encoding P. falciparum CSP and AMA1 induces sterile protection associated with cell-mediated immunity. PLoS One 8:e55571. http://dx.doi.org/10.1371/journal.pone.0055571.

45. Romero P, Maryanski JL, Corradin G, Nussenzweig RS, Nussenzweig V, Zavala F. 1989. Cloned cytotoxic T cells recognize an epitope in the circumsporozoite protein and protect against malaria. Nature 341:323-326. http://dx.doi.org/10.1038/341323a0.

46. Rodrigues MM, Cordey AS, Arreaza G, Corradin G, Romero P, Maryanski JL, Nussenzweig RS, Zavala F. 1991. CD8 ${ }^{+}$cytolytic T cell clones derived against the Plasmodium yoelii circumsporozoite protein protect against malaria. Int. Immunol. 3:579-585. http://dx.doi.org/10.1093 /intimm/3.6.579.

47. Rodrigues M, Nussenzweig RS, Romero P, Zavala F. 1992. The in vivo cytotoxic activity of $\mathrm{CD}^{+} \mathrm{T}$ cell clones correlates with their levels of expression of adhesion molecules. J. Exp. Med. 175:895-905. http://dx.doi .org/10.1084/jem.175.4.895.

48. Schmidt NW, Podyminogin RL, Butler NS, Badovinac VP, Tucker BJ, Bahjat KS, Lauer P, Reyes-Sandoval A, Hutchings CL, Moore AC, Gilbert SC, Hill AV, Bartholomay LC, Harty JT. 2008. Memory CD8 T cell responses exceeding a large but definable threshold provide long-term immunity to malaria. Proc. Natl. Acad. Sci. U. S. A. 105:14017-14022. http://dx.doi.org/10.1073/pnas.0805452105.

49. Yadava A, Sattabongkot J, Washington MA, Ware LA, Majam V, Zheng 
H, Kumar S, Ockenhouse CF. 2007. A novel chimeric Plasmodium vivax circumsporozoite protein induces biologically functional antibodies that recognize both VK210 and VK247 sporozoites. Infect. Immun. 75:11771185. http://dx.doi.org/10.1128/IAI.01667-06.

50. Lumsden JM, Pichyangkul S, Srichairatanakul U, Yongvanitchit K, Limsalakpetch A, Nurmukhambetova S, Klein J, Bertholet S, Vedvick TS, Reed SG, Sattabongkot J, Bennett JW, Polhemus ME, Ockenhouse CF, Howard RF, Yadava A. 2011. Evaluation of the safety and immunogenicity in rhesus monkeys of a recombinant malaria vaccine for Plasmodium vivax with a synthetic Toll-like receptor 4 agonist formulated in an emulsion. Infect. Immun. 79:3492-3500. http://dx.doi.org/10.1128/IAI .05257-11.

51. Moon JJ, Suh H, Li AV, Ockenhouse CF, Yadava A, Irvine DJ. 2012. Enhancing humoral responses to a malaria antigen with nanoparticle vaccines that expand Tfh cells and promote germinal center induction. Proc. Natl. Acad. Sci. U. S. A. 109:1080-1085. http://dx.doi.org/10.1073/pnas .1112648109 .

52. Corradin G, Céspedes N, Verdini A, Kajava AV, Arévalo-Herrera M, Herrera S. 2012. Malaria vaccine development using synthetic peptides as a technical platform. Adv. Immunol. 114:107-149. http://dx.doi.org/10 .1016/B978-0-12-396548-6.00005-6.

53. Gordon DM, Cosgriff TM, Schneider I, Wasserman GF, Majarian WR, Hollingdale MR, Chulay JD. 1990. Safety and immunogenicity of a Plasmodium vivax sporozoite vaccine. Am. J. Trop. Med. Hyg. 42:527-531.

54. Herrington DA, Nardin EH, Losonsky G, Bathurst IC, Barr PJ, Hollingdale MR, Edelman R, Levine MM. 1991. Safety and immunogenicity of a recombinant sporozoite malaria vaccine against Plasmodium vivax. Am. J. Trop. Med. Hyg. 45:695-701.

55. McElrath MJ, De Rosa SC, Moodie Z, Dubey S, Kierstead L, Janes H, Defawe OD, Carter DK, Hural J, Akondy R, Buchbinder SP, Robertson MN, Mehrotra DV, Self SG, Corey L, Shiver JW, Casimiro DR, Step Study Protocol Team. 2008. HIV-1 vaccine-induced immunity in the test-of-concept Step Study: a case-cohort analysis. Lancet 372:1894-1905. http://dx.doi.org/10.1016/S0140-6736(08)61592-5.

56. De Rosa SC, Thomas EP, Bui J, Huang Y, deCamp A, Morgan C, Kalams SA, Tomaras GD, Akondy R, Ahmed R, Lau CY, Graham BS, Nabel GJ, McElrath MJ, National Institute of Allergy and Infectious Diseases HIV Vaccine Trials Network. 2011. HIV-DNA priming alters T cell responses to HIV-adenovirus vaccine even when responses to DNA are undetectable. J. Immunol. 187:3391-3401. http://dx.doi.org/10.4049 /jimmunol.1101421.

57. Frahm N, DeCamp AC, Friedrich DP, Carter DK, Defawe OD, Kublin JG, Casimiro DR, Duerr A, Robertson MN, Buchbinder SP, Huang Y, Spies GA, De Rosa SC, McElrath MJ. 2012. Human adenovirus-specific T cells modulate HIV-specific T cell responses to an Ad5-vectored HIV-1 vaccine. J. Clin. Invest. 122:359-367. http://dx.doi.org/10.1172/JCI60202.

58. Casazza JP, Bowman KA, Adzaku S, Smith EC, Enama ME, Bailer RT, Price DA, Gostick E, Gordon IJ, Ambrozak DR, Nason MC, Roederer M, Andrews CA, Maldarelli FM, Wiegand A, Kearney MF, Persaud D, Ziemniak C, Gottardo R, Ledgerwood JE, Graham BS, Koup RA, VRC 101 Study Team. 2013. Therapeutic vaccination expands and improves the function of the HIV-specific memory T-cell repertoire. J. Infect. Dis. 207:1829-1840. http://dx.doi.org/10.1093/infdis/jit098. 


\section{APÊNDICE D}

Patente - Plasmodium vivax Vaccine Compositions (27522-0201WO1) 
TRANSMITTAL LETTER TO THE UNITED STATES RECEIVING OFFICE

\begin{tabular}{|c|c|}
\hline Submission via EFS-Web (registered user) & Date of deposit: 14 March 2013 \\
\hline File reference no.:27522-0201WO1 & International application no. (if known): \\
\hline Customer Number ${ }^{1}: 26211$ & Earliest priority date claimed (Day/Month/Year): 22/March/2012 \\
\hline
\end{tabular}

${ }^{1}$ Customer Number will allow access to the applic ation in Private PAIR but cannot be used to establish or change the correspondence address.

\section{$\bigotimes \quad$ This is a new International Application \\ SCREENING DISCLOSURE INFORMATION:}

In order to assist in screening the accompanying international application for purposes of determining whether a license for foreign transmittal should and could be granted and for other purposes, the following information is supplied. (check as boxes as apply):

$\square$ The invention disclosed was not made in the United States of America.

$\square \quad$ There is no prior U.S. application relating to this invention.

$\bigotimes \quad$ The following prior U.S. application(s) contain subject matter which is related to the invention disclosed in the attached international application. (NOTE: priority to these applications may or may not be claimed on the Request (form PCT/RO/101) and this listing does not constitute a claim for priority.)

\begin{tabular}{|l|l|l|l|}
\hline Application no. & $61 / 614,439$ & Filed on & 22 March 2012 \\
\hline Application no. & & Filed on & \\
\hline
\end{tabular}

$\bigotimes \quad$ The present international application contains additional subject matter not found in the prior U.S. application(s) identified above. The additional subject matter is found on pages throughout and $\bigotimes$ DOES NOT ALTER

$\square \quad$ MIGHT BE CONSIDERED TO ALTER the general nature of the invention in a manner which would require the U.S. application to have been made available for inspection by the appropriate defense agencies under 35 U.S.C. 181 and 37 C.F.R. 5.15 .

\section{Itemized list of contents}

\begin{tabular}{|c|c|c|c|}
\hline \multicolumn{2}{|c|}{ Sheets of Request form: } & 6 & Please charge Deposit Account No. 06-1050 \\
\hline \multicolumn{2}{|c|}{$\begin{array}{l}\text { Sheets of description } \\
\text { (excluding sequence listing): }\end{array}$} & 57 & Power of attorney: \\
\hline \multicolumn{2}{|c|}{ Sheets of claims: } & 28 & $\begin{array}{l}\text { Certified copy of priority } \\
\text { document (specify): }\end{array}$ \\
\hline \multicolumn{2}{|c|}{ Sheets of abstract: } & 1 & \multirow{4}{*}{$\begin{array}{l}\text { Other (specify): } \\
\text { Sequence Listing in .txt format } \\
\text { PCT-SAFE (easy mode) zip file } \\
\text { Validation Sheet (1 page) } \\
\text { Fee Calculation Sheet ( } 2 \text { pages) }\end{array}$} \\
\hline Sheets of dra & gs: & 5 & \\
\hline \multicolumn{3}{|c|}{ Sheets of sequence listing: } & \\
\hline \multicolumn{3}{|c|}{ Sequence listing diskette/CD: } & \\
\hline \multirow{3}{*}{$\begin{array}{l}\text { The person } \\
\text { signing this } \\
\text { form is: }\end{array}$} & $\square \quad$ Applic & & \multirow[b]{2}{*}{$\begin{array}{l}\text { Irina E. Vainberg } \\
\text { Name of person signing }\end{array}$} \\
\hline & \multicolumn{2}{|c|}{$\bigotimes_{48,008}$ Attorney/Agent (Reg. No.) } & \\
\hline & \multicolumn{2}{|c|}{$\square$ Common Representative } & $\begin{array}{l}\text { /Irina E. Vainberg/ } \\
\text { Signature }\end{array}$ \\
\hline
\end{tabular}

30752564.doc 
275220201WO1

PCT REQUEST

Original (for SUBMISSION

\begin{tabular}{|c|c|c|}
\hline $\begin{array}{l}0 \\
0-1\end{array}$ & $\begin{array}{l}\text { For receiving Office use only } \\
\text { International Application No. }\end{array}$ & \\
\hline $0-2$ & International Filing Date & \\
\hline $0-3$ & $\begin{array}{l}\text { Name of receiving Office and "PCT } \\
\text { International Application" }\end{array}$ & \\
\hline $0-4$ & Form PCT/RO/101 PCT Request & \\
\hline $0-4-1$ & Prepared Using & $\begin{array}{l}\text { PCT-SAFE [EASY/EFS-Web mode] } \\
\text { Version } 3.51 .057 .233 \mathrm{MT} / \mathrm{FOP} \\
20130101 / 0.20 .5 .20\end{array}$ \\
\hline $0-5$ & $\begin{array}{l}\text { Petition } \\
\text { The undersigned requests that the } \\
\text { present international application be } \\
\text { processed according to the Patent } \\
\text { Cooperation Treaty }\end{array}$ & \\
\hline $0-6$ & $\begin{array}{l}\text { Receiving Office (specified by the } \\
\text { applicant) }\end{array}$ & $\begin{array}{l}\text { United States Patent and Trademark } \\
\text { Office (USPTO) (RO/US) }\end{array}$ \\
\hline $0-7$ & Applicant's or agent's file reference & 275220201 WO1 \\
\hline I & Title of Invention & PLASMODIUM VIVAX VACCINE COMPOSITIONS \\
\hline $\begin{array}{l}\text { II } \\
\text { II-1 }\end{array}$ & $\begin{array}{l}\text { Applicant } \\
\text { This person is }\end{array}$ & Applicant only \\
\hline$\|-2$ & Applicant for & All designated states \\
\hline II-4 & Name & NEW YORK UNIVERSITY \\
\hline II-5 & Address & $\begin{array}{l}70 \text { Washington Square South } \\
\text { New York, New York } 10012 \\
\text { United States of America }\end{array}$ \\
\hline$\| 1-6$ & State of nationality & US \\
\hline $11-7$ & State of residence & US \\
\hline $\begin{array}{l}\mathrm{III}-1 \\
\mathrm{III-1}-1\end{array}$ & $\begin{array}{l}\text { Applicant and/or inventor } \\
\text { This person is }\end{array}$ & Applicant only \\
\hline III-1-2 & Applicant for & All designated states \\
\hline III-1-4 & Name & UNIVERSIDADE DE SAO PAULO \\
\hline III-1-5 & Address & $\begin{array}{l}\text { Rua da Praca do Relogio, } 109 \text { Cidade } \\
\text { Universitária } \\
\text { 05508-050 Sao Paulo, SP } \\
\text { Brazil }\end{array}$ \\
\hline III-1-6 & State of nationality & BR \\
\hline III-1-7 & State of residence & BR \\
\hline
\end{tabular}


Original (for SUBMISSION )

\begin{tabular}{|c|c|c|}
\hline $\begin{array}{l}\mathrm{III}-2 \\
\mathrm{III}-2-1\end{array}$ & $\begin{array}{l}\text { Applicant and/or inventor } \\
\text { This person is }\end{array}$ & Applicant only \\
\hline III-2-2 & Applicant for & All designated states \\
\hline III-2-4 & Name & $\begin{array}{l}\text { THE WISTAR INSTITUTE OF ANATOMY AND } \\
\text { BIOLOGY }\end{array}$ \\
\hline III-2-6 & $\begin{array}{l}\text { Address } \\
\text { State of nationality }\end{array}$ & $\begin{array}{l}3601 \text { Spruce Street } \\
\text { Philadelphia, Pennsylvania } 19104 \\
\text { United States of America } \\
\text { US }\end{array}$ \\
\hline III-2-7 & State of residence & US \\
\hline $\begin{array}{l}\mathrm{III}-3 \\
\mathrm{III}-3-1\end{array}$ & $\begin{array}{l}\text { Applicant and/or inventor } \\
\text { This person is }\end{array}$ & Applicant only \\
\hline III-3-2 & Applicant for & All designated states \\
\hline III-3-4 & Name & $\begin{array}{l}\text { UNIVERSIDADE FEDERAL DE MINAS GERAIS - } \\
\text { UFMG }\end{array}$ \\
\hline III-3-5 & Address & $\begin{array}{l}\text { Avenida Antônio Carlos } 6627 \text { Reitoria } 7^{\circ} \\
\text { Andar Sala } 7005 \text { Campus UFMG- Pampulha } \\
31270-901 \text { Belo Horizonte, mg } \\
\text { Brazil }\end{array}$ \\
\hline III-3-6 & State of nationality & BR \\
\hline III-3-7 & State of residence & BR \\
\hline $\begin{array}{l}\mathrm{III}-4 \\
\mathrm{III}-4-1\end{array}$ & $\begin{array}{l}\text { Applicant and/or inventor } \\
\text { This person is }\end{array}$ & Applicant and inventor \\
\hline III-4-2 & Applicant for & All designated states \\
\hline III-4-4 & Name (LAST, First) & RODRIGUES, Mauricio Martins \\
\hline III-4-5 & Address & $\begin{array}{l}\text { Rua Corgie Assad Abdalla, 1030, AP. } 31 \\
05622-010 \text { Sao Paulo, SP } \\
\text { Brazil }\end{array}$ \\
\hline III-4-6 & State of nationality & BR \\
\hline III-4-7 & State of residence & \\
\hline$\overline{\mathrm{III}-5}$ & Applicant and/or inventor & \\
\hline III-5-1 & This person is & Applicant and inventor \\
\hline III-5-2 & Applicant for & All designated States \\
\hline III-5-4 & Name (LAST, First) & TEIXEIRA, Laís Helena \\
\hline III-5-5 & Address & $\begin{array}{l}\text { R. Frederico Ozanan, } 11 \text { apto } 104 \\
11065-240 \text { Santos, SP } \\
\text { Brazil }\end{array}$ \\
\hline III-5-6 & State of nationality & BR \\
\hline III-5-7 & State of residence & \\
\hline
\end{tabular}


Original (for SUBMISSION

\begin{tabular}{|c|c|c|}
\hline $\begin{array}{l}\mathrm{III-6} \\
\mathrm{III-6-1}\end{array}$ & $\begin{array}{l}\text { Applicant and/or inventor } \\
\text { This person is }\end{array}$ & Applicant and inventor \\
\hline III-6-2 & Applicant for & All designated states \\
\hline III-6-4 & Name (LAST, First) & TARARAM, Cibele Aparacida \\
\hline III-6-5 & Address & $\begin{array}{l}\text { Rua Antônio Arzola Sobrinho } 640 \text { Bairro } \\
\text { São Cristovão II } \\
\text { 13390-000 Rio das Pedras, SP } \\
\text { Brazil }\end{array}$ \\
\hline III-6-6 & State of nationality & 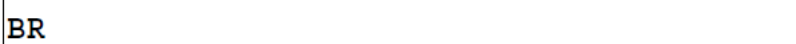 \\
\hline III-6-7 & State of residence & BR \\
\hline III-7 & Applicant and/or inventor & \\
\hline III-7-1 & This person is & Applicant and inventor \\
\hline III-7-2 & Applicant for & All designated states \\
\hline III-7-4 & Name (LAST, First) & JAMPAULO, Vander Oliveira \\
\hline III-7-5 & Address & $\begin{array}{l}\text { Rua Minas Gerais } 17-55 \text { Bloco } 3 \text { Apto 204, } \\
\text { Pq Paulistano } \\
17030-511 \text { Bauru, SP } \\
\text { Brazil }\end{array}$ \\
\hline III-7-6 & State of nationality & BR \\
\hline III-7-7 & State of residence & BR \\
\hline III-8 & Applicant and/or inventor & \\
\hline III-8-1 & This person is & Inventor only \\
\hline $\begin{array}{l}\text { III-8-3 } \\
\text { III-8-4 }\end{array}$ & $\begin{array}{l}\text { Inventor for } \\
\text { Name (LAST, First) }\end{array}$ & NUSSENZWEIG, Victor $\mathrm{N}$. \\
\hline III-8-5 & Address & $\begin{array}{l}110 \text { Bleecker Street } \\
\text { New York, New York } 10012 \\
\text { United States of America }\end{array}$ \\
\hline III-9 & Applicant and/or inventor & \\
\hline III-9-1 & This person is & Inventor only \\
\hline III-9-3 & Inventor for & \\
\hline III-9-4 & Name (LAST, First) & NUSSENZWEIG, Ruth \\
\hline III-9-5 & Address & $\begin{array}{l}110 \text { Bleecker Street } \\
\text { New York, New York } 10012 \\
\text { United States of America }\end{array}$ \\
\hline III-10 & Applicant and/or inventor & \\
\hline III-10-1 & This person is & Inventor only \\
\hline III-10-3 & Inventor for & \\
\hline III-10-4 & Name (LAST, First) & SOARES, Irene da Silva \\
\hline III- $-10-5$ & Address & $\begin{array}{l}\text { Rua Corgie Assad Abdalla, } 1030 \text { AP. } 31 \\
05622-010 \text { Sao Paulo, SP } \\
\text { Brazil }\end{array}$ \\
\hline
\end{tabular}


Original (for SUBMISSION )

\begin{tabular}{|c|c|c|}
\hline $\begin{array}{ll}\mathrm{III-11} \\
\mathrm{III-11-1}\end{array}$ & Applicant and/or inventor & \\
\hline||$l \mid-11-3$ & Inventor for & Inventor only \\
\hline III-11-4 & Name (LAST, First) & ERTL, Hildegund C.J. \\
\hline III-11-5 & Address & $\begin{array}{l}1929 \text { Montgomery Avenue } \\
\text { Villanova, Pennsylvania } 19085 \\
\text { United States of America }\end{array}$ \\
\hline III-12 & Applicant and/or inventor & \\
\hline III-12-1 & This person is & Inventor only \\
\hline $\begin{array}{l}\text { III-12-3 } \\
\text { III-12-4 }\end{array}$ & $\begin{array}{l}\text { Inventor for } \\
\text { Name (LAST, First) }\end{array}$ & JAASARO Marcio de oliveira \\
\hline III-12-5 & Address & $\begin{array}{l}\text { 95A Walnut Tree Hill Rd } \\
\text { Sandy Hook, Connecticut } 06482 \\
\text { United States of America }\end{array}$ \\
\hline 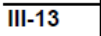 & Applicant and/or inventor & \\
\hline III-13-1 & This person is & Inventor only \\
\hline III-13-3 & Inventor for & \\
\hline III-13-4 & Name (LAST, First) & BRUNA-ROMERO, Oscar \\
\hline III-13-5 & Address & $\begin{array}{l}\text { Rua Wilson Modesto Ribeiro } 155 \text { apto } 301 \\
\text { Ipiranga } \\
31160-430 \text { Belo Horizonte, MG } \\
\text { Brazil }\end{array}$ \\
\hline \multirow[t]{2}{*}{$\mathrm{IV}-1$} & $\begin{array}{l}\text { Agent or common representative; or } \\
\text { address for correspondence }\end{array}$ & \\
\hline & $\begin{array}{l}\text { The person identified below is hereby/ } \\
\text { has been appointed to act on behalf of } \\
\text { the applicant(s) before the competent } \\
\text { International Authorities as: }\end{array}$ & Agent \\
\hline IV-1-1 & Name (LAST, First) & VAINBERG, Irina E. \\
\hline IV-1-2 & Address & $\begin{array}{l}\text { Fish \& Richardson P.C. } \\
\text { P.O. Box 1022 } \\
\text { Minneapolis, Minnesota 55440-1022 } \\
\text { United States of America }\end{array}$ \\
\hline IV-1-3 & Telephone No. & $(212) \quad 765-5070$ \\
\hline IV-1-4 & Facsimile No. & $(877) \quad 769-7945$ \\
\hline IV-1-5 & e-mail & APSI@FR.com \\
\hline$)^{I V-1-5(a)}$ & $\begin{array}{l}\text { E-mail authorization } \\
\text { The receiving Office, the International } \\
\text { Searching Authority, the International } \\
\text { Bureau and the International Preliminary } \\
\text { Examining Authority are authorized to } \\
\text { use this e-mail address, if the Office or } \\
\text { Authority so wishes, to send notifications } \\
\text { issued in respect of this international } \\
\text { application: }\end{array}$ & $\begin{array}{l}\text { as advance copies followed by paper } \\
\text { notifications }\end{array}$ \\
\hline IV-1-6 & Agent's registration No. & 48,008 \\
\hline $\mathrm{IV}-2$ & Additional agent(s) & $\begin{array}{l}\text { additional agent(s) with same address as } \\
\text { first named agent }\end{array}$ \\
\hline IV-2-1 & Name(s) & $\begin{array}{l}\text { LUDWIG, S. Peter }(25,351) ; \text { TAN, Anna } \\
\text { M. }(74,463)\end{array}$ \\
\hline
\end{tabular}




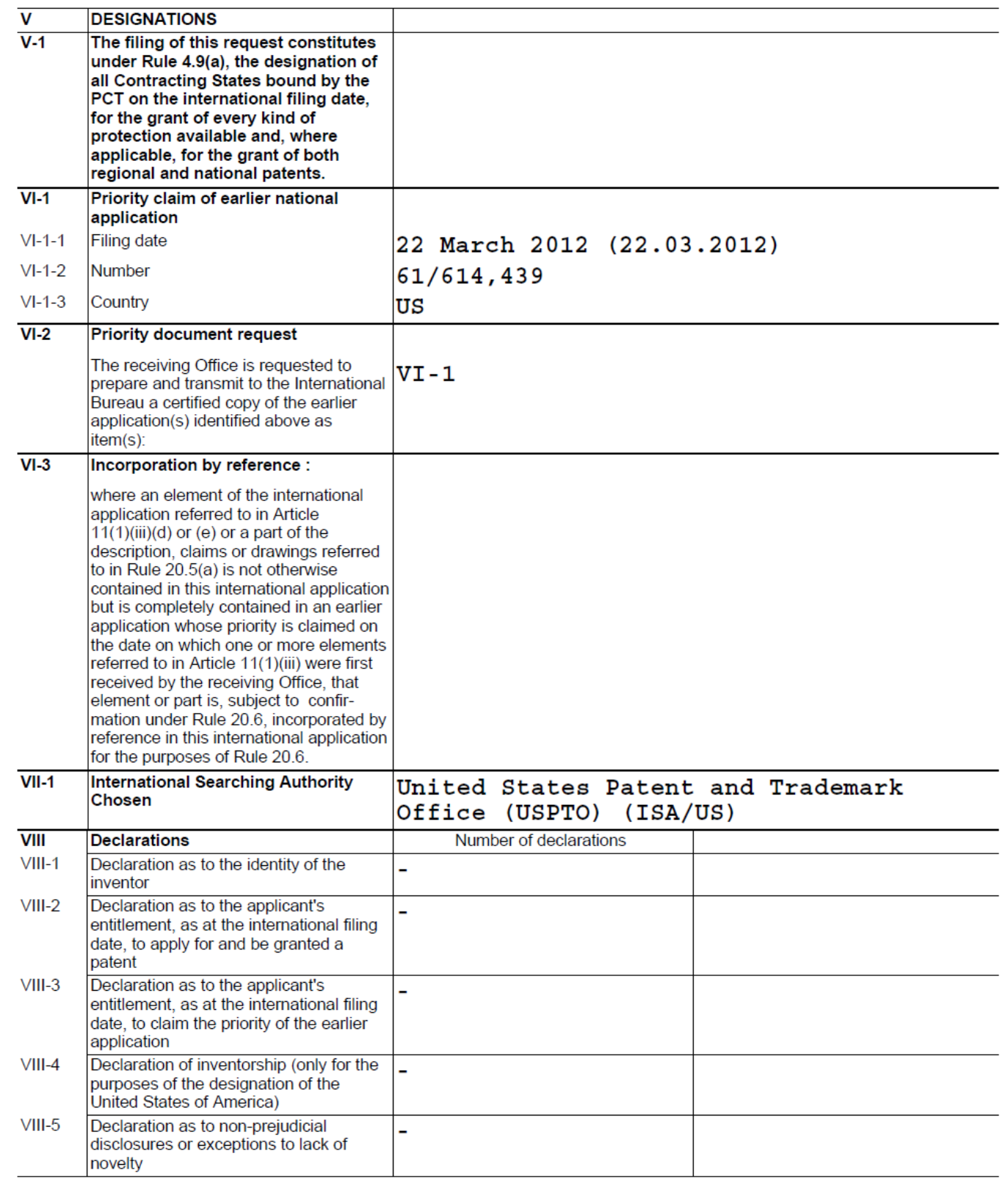


Original (for SUBMISSION )

\begin{tabular}{|c|c|c|c|}
\hline$\overline{I X}$ & Check list & Number of sheets & Electronic file(s) attached \\
\hline $\mathrm{IX}-1$ & Request (including declaration sheets) & 6 & $\checkmark$ \\
\hline $\mathrm{IX}-2$ & Description & 57 & - \\
\hline IX-3 & Claims & 28 & - \\
\hline IX-4 & Abstract & 1 & $\checkmark$ \\
\hline IX-5 & Drawings & 5 & - \\
\hline IX-6a & $\begin{array}{l}\text { Sequence listing part of the description } \\
\text { (also to be used for the purposes of } \\
\text { international search) }\end{array}$ & - & $\checkmark$ \\
\hline IX-7 & TOTAL & 97 & \\
\hline & Accompanying Items & Paper document(s) attached & Electronic file(s) attached \\
\hline IX-8 & Fee calculation sheet & $\checkmark$ & - \\
\hline IX-20 & $\begin{array}{l}\text { Figure of the drawings which should } \\
\text { accompany the abstract }\end{array}$ & 1 & \\
\hline IX-21 & $\begin{array}{l}\text { Language of filing of the international } \\
\text { application }\end{array}$ & English & \\
\hline $\mathrm{X}-1$ & $\begin{array}{l}\text { Signature of applicant, agent or } \\
\text { common representative }\end{array}$ & /Irina E. Vainberg, & . No. $48,008 /$ \\
\hline $\mathrm{X}-1-1$ & Name (LAST, First) & \multirow[t]{3}{*}{ VAINBERG, Irina E. } & \\
\hline$x-1-2$ & Name of signatory & & \\
\hline$X-1-3$ & $\begin{array}{l}\text { Capacity (if such capacity is not obvious } \\
\text { from reading the request) }\end{array}$ & & \\
\hline
\end{tabular}

FOR RECEIVING OFFICE USE ONLY

\begin{tabular}{l|l|l}
\hline $10-1$ & $\begin{array}{l}\text { Date of actual receipt of the } \\
\text { purported international application }\end{array}$ & \\
\hline $10-2$ & $\begin{array}{l}\text { Drawings: } \\
10-2-1\end{array}$ & $\begin{array}{l}\text { Received } \\
\text { Not received }\end{array}$ \\
\hline $10-2-2$ & $\begin{array}{l}\text { Corrected date of actual receipt due } \\
\text { to later but timely received papers or } \\
\text { drawings completing the purported } \\
\text { international application }\end{array}$ & \\
\hline $10-4$ & $\begin{array}{l}\text { Date of timely receipt of the required } \\
\text { corrections under PCT Article 11(2) }\end{array}$ & \\
\hline $10-5$ & International Searching Authority & ISA/US \\
\hline $10-6$ & $\begin{array}{l}\text { Transmittal of search copy delayed } \\
\text { until search fee is paid }\end{array}$ & \\
\hline
\end{tabular}

FOR INTERNATIONAL BUREAU USE ONLY 
PCT (ANNEX - FEE CALCULATION SHEET)

Original (for SUBMISSION

(This sheet is not part of and does not count as a sheet of the international application)

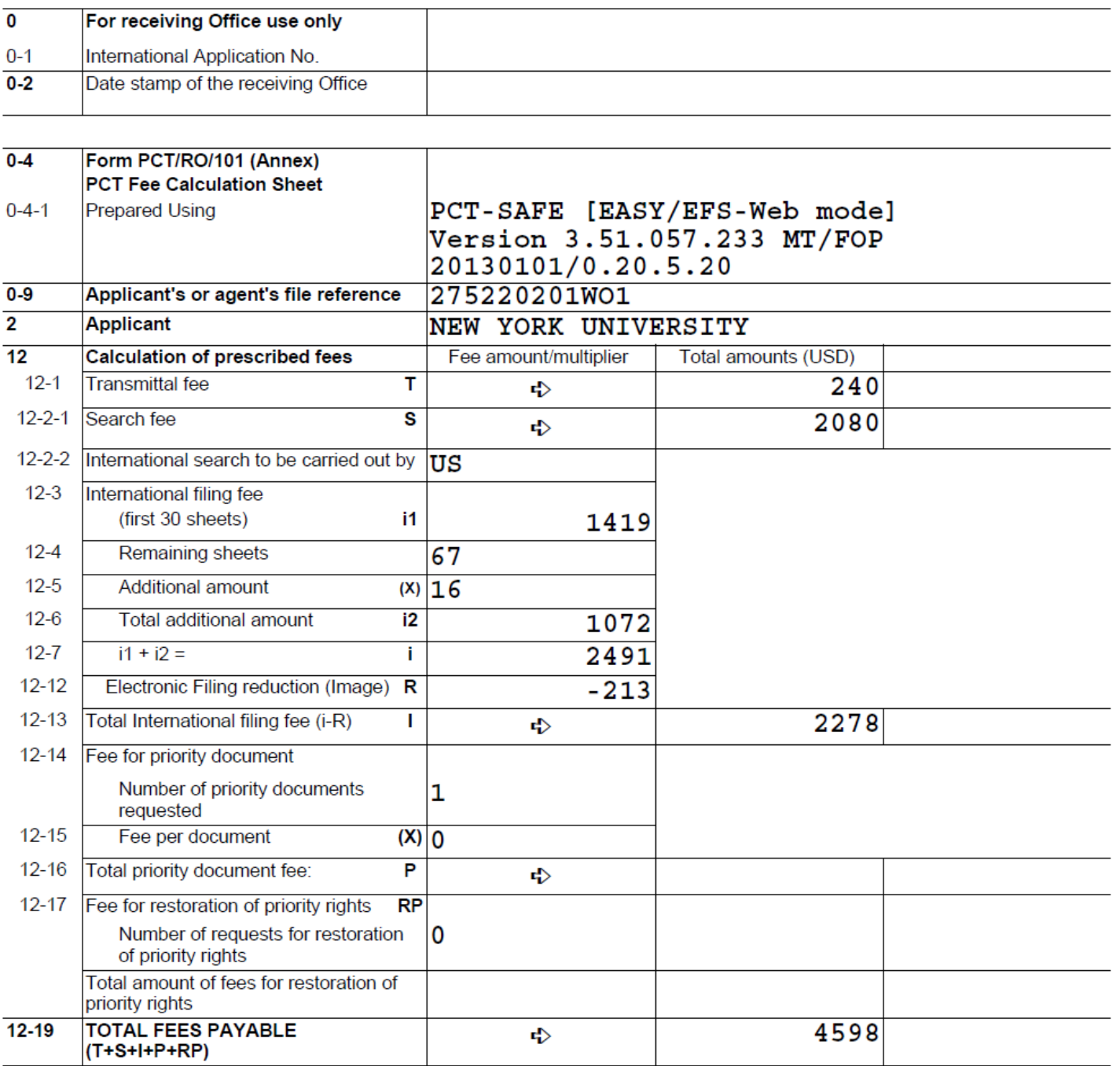


PCT (ANNEX - FEE CALCULATION SHEET)

Original (for SUBMISSION )

(This sheet is not part of and does not count as a sheet of the international application)

\begin{tabular}{l|l|l}
\hline $\mathbf{1 2 - 2 1}$ & Mode of payment & Authorization to charge current account \\
\hline $\mathbf{1 2 - 2 2}$ & $\begin{array}{l}\text { Current account instructions } \\
\text { The receiving office }\end{array}$ & $\begin{array}{l}\text { United States Patent and Trademark } \\
\text { Office (USPTO) }\end{array}$ \\
\hline $12-22-1$ & $\begin{array}{l}\text { Authorization to charge the total fees } \\
\text { indicated above }\end{array}$ & $\checkmark$ \\
\hline $12-22-2$ & $\begin{array}{l}\text { Authorization to charge any deficiency or } \\
\text { credit any overpayment in the total fees } \\
\text { indicated above }\end{array}$ & $\checkmark$ \\
\hline $12-22-3$ & $\begin{array}{l}\text { Authorization to charge the fee for } \\
\text { priority document }\end{array}$ & $\checkmark$ \\
\hline $12-23$ & Current account No. & 061050 \\
\hline $12-24$ & Date & 14 March 2013 (14.03.2013) \\
\hline $12-25$ & Name and signature & IRINA E. VAINBERG, \\
& & $/$ Irina E. Vainberg, Reg. No. 48,008/ \\
\hline
\end{tabular}

